EL ULTRAÍSMO 
BIBLIOTECA ROMÁNICA HISPÁNICA

DIRIGIDA POR DÁMASO ALONSO

II. ESTUDIOS Y ENSAYOS 


\section{GLORIA VIDELA}

\section{EL ULTRAÍSMO}

ESTUDIOS SOBRE MOVIMIENTOS POÉTICOS

DE VANGUARDIA EN ESPAÑA

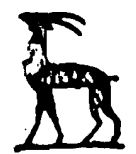

BIBLIOTECA ROMANICA HISPÁNICA

EDITORIAL GREDOS - JOSÉ FERRER, S. A. 
(c) Editorial_Gredos Madrid, 1963.

N. ${ }^{\circ}$ de Registro: 696-63. - Depósito Legal: M. 1.845-1963 Gráficas Cóndor, S. A. - Aviador Lindbergh, 5. - Madrid - 2. $1863-1963$ 


\section{INTRODUCCION}

EL TEMA

Varios fueron los motivos que nos decidieran a trabajak sóbre el ultraísmo español.

Primeramente, el hecho de que no exista un estudio o una historia detallada de este movimiento. Los críticos literarios generalmente lo han pasado por alto o han aludido a él con una frase o un párrafo, casi siempre despectivo.

Por otra parte, el ultraísmo tuvo una gran repercusión en América. Un estudio amplio y documentado de este movimiento en España abre posibilidades para investigar con más profundidad su desarrollo en las literaturas hispanoamericanas y para establecer relaciones entre la poesía americana y española después del modernismo.

Estas relaciones son estrechas ya desde los orígenes del ultraísmo. Recordemos que la influencia del chileno Vicente Huidobro es fundamental, que el argentino Jorge Luis Borges participó en él y que, recíprocamente, los jóvenes españoles colabo. raron en las primeras publicaciones ultraístas argentinas. Son pues movimientos casi simultáneos y entrelazados.

Por último, deseábamos aprovechar las grandes posibilidades que España ofrece para trabajar sobre documentos origi- 
nales. Muchos temas pueden desarrollarse consultando una bibliografía accesible y difundida. Pero una historia del ultraísmo sólo podía hacerse en España, donde viven algunos de los principales protagonistas del movimiento y donde pueden encontrarse las fuentes documentales.

LAS FUENTES

Los datos históricos y la obra de los poetas ultraístas están, por lo general, dispersos en revistas, en periódicos de la época, o en libros de difícil acceso. En ningún sitio se encuentran completas las colecciones de revistas del movimiento. Hemos tenido que reconstruirlas poco a poco en las distintas hemerotecas, bibliotecas y archivos literarios particulares.

El libro fundamental es Literaturas europeas de vanguardia (1925), de Guillermo de Torre. No ha sido reeditado y no es fácil encontrarlo. Hemos citado con mucha frecuencia esta obra. Sabemos que hoy su autor ha cambiado muchos de sus puntos de vista: la perspectiva da siempre otra visión de los hechos. Por ello hemos procurado no utilizar las opiniones que denotan la parcialidad de quien participó en polémicas juveniles, hoy superadas y olvidadas. Pero si nos ha interesado transcribir con respecto a los diferentes puntos de este trabajo, la opinión de un autor que vivió, promovió e historió el ultraismo, opinión y testimonio que son indispensables para el conocimiento de este período literario.

CRITERIOS SEGUIDOS

Se nos han presentado durante la redacción de este estudio algunas dudas.

Hemos vacilado varias veces acerca de la conveniencia de transcribir o no determinados documentos. Sabemos que en mu- 
chas ocasiones es necesario renunciar al material para no caer en repeticiones o falta de agilidad. Por este motivo hemos prescindido de muchos documentos, o nos hemos limitado, a hacer una referencia a pie de página o a pasarlos a un apéndice.

Sin embargo algunas veces nos hemos decidido por la afirmativa y hemos incluido textualmente datos, crónicas, manifiestos e incluso algunas poesías que, a pesar de su escaso valor poético, son programáticas o sirven de testimonio histórico. Ello porque pensamos que si algún valor tiene este libro es, justamente, el documental, el de ofrecer de un modo orgánico una recopilación del material recogido tras arduas búsquedas y que procede de fuentes prácticamente inaccesibles, especialmente para los americanos. El panorama queda así abierto para quienes deseen seguir profundizando estos temas.

También con esta intención documental hemos hecho una pequeña antología comentada de los poetas del movimiento. En la selección de las poesías hemos buscado unas veces el valor poético, otras, algún rasgo o dirección representativa dentro de Ultra.

Otras dudas se nos han planteado: ¿Qué alcance darle a la "pequeña historia" del ultraísmo, a su faceta pintoresca, a veces escandalosa? Estos "gestos y actitudes" - como los llama Guillermo de Torre- constituyen un aspecto fundamental de éste, como de casi todos los movimientos de vanguardia europeos, un reflejo de la actitud provocativa e iconoclasta frente a las letras y frente a la vida. Por ello hemos creído necesario incluir estos pormenores.

Por último diremos que, aunque casi siempre se ha aludido al ultraísmo desde una actitud previa negativa, hemos tratado de adoptar, para historiarlo y juzgarlo, la posición de un observador imparcial. 


\section{PALABRAS DE AGRADECIMIENTO}

Deseo especialmente manifestar mi profunda gratitud a don Dámaso Alonso por su generosidad y sabia orientación.

Igualmente quiero agradecer a don Gerardo Diego, a don Rafael Cansinos-Asséns, a don Guillermo de Torre, a don Jorge Campos, a la señora viuda de Guerrero, a don Francisco Luis Bernárdez, a don Rafael Santos Torroella, y a todos aquellos que me han facilitado material, me han permitido el acceso a sus archivos o por medio de cartas o entrevistas me han referido sus recuerdos personales o proporcionado algún dato. 


\title{
Capítulo Primero
}

\section{RELACION DEL ULTRAISMO CON EL PASADO LITERARIO ESPAÑOL}

\author{
P A NOR A M A LITERARIO Y \\ RELACIÓN CON EL MODERNISMO
}

Un proceso literario que enraiza en el romanticismo del siglo XIX $y$ entra en el siglo $\mathrm{XX}$ por la brillante $\mathrm{y}$ refinada puerta del modernismo, conduce a la poesía de la generación del veintisiete y sus continuadores. Queda sin embargo casi en sombras un período literario intermedio : el que corresponde al breve y ruidoso "ultraísmo" español. Este ha sido en general descuidado por los historiadores de la literatura, en razón del escaso valor poético de su producción '. Creemos sin embargo

1 Casi todos los antólogos e historiadores de la poesía española en la primera mitad de este siglo han omitido los nombres de los poetas ultraístas. FEDERICO DE ONis, por ejemplo, en su Antología utiliza el nombre, pero no lo aplica al movimiento sino que con él designa a poetas de la promoción siguiente: Salinas, Guillén, Lorca...

José María Souvirón, en la segunda edición (1947) de su Antología de poetas españoles contemporáneos recoge poesías y noticias de algunos ultraístas. También lo hace CÉSAR GONZÁlEZ-Ruano en su Antología de poetas españoles contemporáner's en la lengua castellana (1946).

Dámaso Alonso. en su artículo "Góngora y la literatura contemporánea" (1932) que incluyó " ego en su libro Estudios y ensayos gongorinos (1955), y en 
que merece un estudio más detenido y benévolo, pues sin él no se explica la transición del modernismo a uno de los más brillantes períodos de la lirica española. Si queremos esclarecer la trayectoria poética en el presente siglo, no podemos arrinconar y olvidar al movimiento ultraista.

Aparece éste en los primeros años posteriores a la gran guerra, como reacción al modernismo post-rubeniano, como consecuencia del creciente irracionalismo e individualismo que condicionan la lírica contemporánea y como un reflejo de otros movimientos literarios de vanguardia que se desarrollaban fuera de las fronteras españolas. Los jóvenes ultraístas desearon "poner su reloj con el de Europa" 2.

Debemos mencionar además otros factores influyentes no estrictamente literarios : la post-guerra europea originó un enervamiento, un afán dinámico y renovador. Las literaturas de otros países se habían hecho ya eco de rasgos característicos de la nueva época, quizás porque se hacían sentir alli con más intensidad que en España: la prisa, la ansiedad, las preocupaciones, la vida agitada y anhelante de las grandes ciudades, las anónimas muchedumbres de las calles, la industrialización, el maquinismo. En suma, una progresiva deshumanización. Agreguemos a esto el jazz, el cinematógrafo, el deporte, el psicoanálisis y otras fuerzas de nuestro siglo.

Los ultraístas desearon también ser voceros de este mundo nuevo y buscaron para ello una nueva voz.

Pero de todos estos factores que condicionaron la aparición del ultraismo, nos interesa fundamentalmente señalar y analizar el fenómeno estrictamente literario, el movimiento ultraísta co-

los capítulos "La poesía de Gcrardo Diego" y "Una generación poética (rg201936)" de Poetas españoles contemporáneos (1958), es.uno de los pocos críticos e historiadores que reconoce al ultraismo un pape' la evolución poética de este siglo. (CF. nuestra Conclusión: "Balance y fin a ultraísmo".)

2 Cf. TORRE, GUILLERMO DE, Literaluras europeas de sanguardia, Madrid, 1925. pág. 48. 
mo fase de un proceso evolutivo en el seno mismo de la literatura.

Cuando irrumpen los jóvenes ultraístas en la vida literaria se encuentran, sí, con la presencia de figuras que mantenían intacto su prestigio: Unamuno, Valle Inclán, los Machado, Juan Ramón Jiménez, pero en cambio había una pléyadè de imitadores de Rubén Darío, en lo que su poesía tiene de más superficial y perecedero. Poetas "típicamente modernistas" desarrollaban hasta el cansancio determinadas facetas rubenianas.? Proliferaban así las princesas, condesas y duquesas, las pedrerías orientales, los parques húmedos y crepusculares, los cipreses, los colores difuminados, las musas enfermas, los ensueños. las quimeras, los sentimientos otoñales, el morbo melancólico. $\mathrm{Y}$ a pesar de los muchos aciertos - logros de serena belleza-, éstos comienzan a convertirse en fáciles caminos trillados, en fórmulas que se repiten y desgastan.:

Como una reacción contra este agotamiento surge, pues, el ultraísmo. Asi lo declara Guillermo de Torre, el teórico y el historiador del movimiento:

Como una violenta reacción contra la era del rubenia. nismo agonizante y toda su anexa cohorte de cantores fáciles que habian llegado a formar un género híbrido y confuso, especie de bisutería poética, producto de feria para las revistas burguesas; y superando las tímidas metas de algunos otros poetas independientes, mas desprovistos de verdadera savia original y potencia innovadora, se imponía un mo. vimiento simultáneamente derrocador $y$ constructor ${ }^{3}$.

Conceptos e intenciones semejantes enuncia el poeta argentino Jorge Luis Borges en un artículo publicado en la revista Nosotros:

3 Literaturas..., pág. 46. 
Cabe empalmar una expresión de Torres Villarroel y decir que, considerado como cosa viviente, capaz de forjar belleza nueva o de espolear entusiasmos, el rubenianismo se halla a las once $y$ tres cuartos de su vida, con las pruebas terminadas para esqueleto. Esto lo afirmo, pese a la numerosidad de monederos falsos del arte que nos imponen aún las oxidaciones de figuras mitológicas y los desdibujados $y$ lejanos epítetos que prodigara Darío en muchos de sus poemas. La belleza rubeniana es ya una cosa madurada y colmada, semejante a la belleza de un lienzo antiguo, cumplida y eficaz en la limitación de sus métodos y en nuestra aquies. cencia al dejarnos herir por sus previstos recursos; pero por eso mismo, es una cosa acabada, concluida, anonadada.

- Ya sabemos que manejando palabras crepusculares, apuntaciones de colores y evocaciones versallescas o helénicas, se logran determinados efectos, y es porfía desatinada e inútil seguir haciendo eternamente la prueba 4.

A pesar de la reacción antimodernista, de la intención iconoclasta proclamada por los nuevos poetas, ¿podemos afirmar, como lo hizo Guillermo de Torre, que la promoción ultraísta "ha roto totalmente el cordón umbilical que pudiera unirle al ochocientos"? 5 .

'Si analizamos paralelamente el proceso de la lírica francesa, vemos que la poesía de vanguardia tiene sus orígenes en el siglo XIX. El romanticismo, Baudelaire, Rimbaud, Mallarmé, fueron progresivamente estructurando la nueva lírica ${ }^{6}$ :

El ultraísmo que se nutrió en gran parte del vanguardismo francés, permaneció a través de él. ligado en alguna medida al ochocientos.

4 En Nosotros, XXXIX, núm. 151. Buenos Aires, dic. 1921, pág. 466.

5 Literaturas..., pág. 39.

6 Cf. Friedrich, Hugo, Estructura de la livica modema, Barcelona, 1959. 
Ciñéndonos al proceso español, observamos que muchos de los rasgos de la modernidad arrancan del siglo pasado y se van intensificando a medida que se acentúan el individualismo y el irracionalismo. Los poetas introducen nuevos procedimientos estilísticos adecuados a la actitud espiritual del hombre contemporáneo (desplazamientos calificativos, imágenes visionarias, superposiciones, etc., según la terminología de Carlos Bousoño) ${ }^{7}$.

Pero este proceso, que se realizaba con lentitud, se intensifica bruscamente a partir de 1918; la corriente se precipita con estrépito por obra y gracia de Ultra.

El movimiento ultraísta presenta pues algunos rasgos que se anunciaban en la poesía anterior, pero introduce bruscamente caracteres nuevos que toma de líricas vanguardistas europeas y tiene además una indudable intención iconoclasta. El enjuiciamiento del pasado artístico (con matices que van desde lo burlón a lo violento) y el intento destructivo, son llevados a excesos de inspiración dadaísta, que ponen en peligro la existencia misma de la literatura.

\section{+ ANTECEDENTES DEL ULTRAísMo EN ESPAÑA}

Hemos hecho referencia a la existencia de actitudes y rasgos estilísticos que anticipan en alguna medida al ultraísmo.

-Pero el movimiento tiene un precursor evidente: Ramón Gómez de la Serna. Más dudoso, aunque reconocido por Guillermo de Torre y Cansinos-Asséns, es el papel precursor de Juan Ramón Jiménez.

Ramón Gómez de la Serna

Ramón Gómez de la Serna (1891-1963), madrileño, hombre excéntrico, pintoresco, exuberante y dinámico, escritor fecundísimo, tuvo desde temprano el anhelo de un arte nuevo.

7 Cf. Teoria de la expresión poética, Madrid, 1956. 
Así lo afirma Cansinos-Asséns en un artículo aparecido en Cosmópolis en 19.19: "El nuevo arte, que ya va siendo viejo, aunque sólo ahora logra plenitud de atención, alborea entre nosotros, en la obra de un joven, ya granado de años y de libros. Me refiero al autor de Greguerias" ${ }^{8}$. Así lo reconoce también Guillermo de Torre:

Gómez de la Serna puede reivindicar en todo momento, con más motivos que ningún otro de su edad, una indiscutible prioridad vanguardista... ha sido siempre un hombre de vanguardia, anticipado a su época, disidente e impar, única figura de relieve singular $y$ de aportaciones propias en la promoción de $1908^{9}$.

Aunque Gómez de la Serna es prosista, son muchas las razones que justifican su inclusión como precursor del ultraísmo y de ciertos aspectos de la obra poética de la generación del veintisiete. Tuvo, con prioridad histórica, la preocupación por "lo nuevo", que fue obsesión en los ultraístas. Expresó su afán reformador en proclamas, manifiestos y prólogos; tuvo contacto con el futurismo italiano cuando todavía en España el modernismo estaba en pleno auge; su estilo literario refleja su deseo de originalidad. En su prosa - con evidentes matices líricos que nos permiten considerarlo como precursor de un movimiento poético- aparecen muchos de los rasgos que caracterizan a la lírica de vanguardia: la profusión de imágenes y metáforas (la "greguería"), los juegos de ingenio, el humorismo. el arte sin trascendencia.

Analicemos con más detención estos caracteres enunciados:

En noviembre de 1908 aparece la revista Prometeo, fundada por Javier Gómez de la Serna y dirigida por Ramón. De

8 Cansinos-Asséns, Rafael, "El Arte Nuevo", en Cosmópolis, I, núm. 2 , Madrid, 1919, pág. 262.

9 Op. cit., págs. 43 y 44. 
esta revista, que se publicó hasta 1912, nos dice Cansinos-Asséns, en el artículo antes citado:

Las nuevas modalidades literarias nos han llegado por la intercesión de Prometeo, la memorable revista que en 1910 recogió la herencia de Helios y Renacimiento, y pobló con multitud de intenciones y gestos la soledad de nuestras letras. En Prometeo se publicaron traducciones de los poetas ultrasimbólicos y fantasistas: de Saint Pol Roux, de Klingsor, de Paul Fort... Con la máscara de Tristán, Gómez de la Serna glosó apasionadamente los manifiestos futuristas que Marinetti lanzaba desde su encharcada Venecia. Y el mismo Marinetti, instigado por Tristán, envió a Prometeo su encíclica futurista a los españoles, habitantes de ciudades muertas, de infecundas lagunas de polvo. No obstante su devcción a los últimos maestros del siglo XIX, manifiesta en traducciones de Wilde, de Remy de Gourmont y de Rachilde, Prometeo fue entre nosotros un manifiesto de arte nuevo, ciue ensanchó el horizonte de los espejos, de los últimos cenáculos novecentistas... Con su amalgama de antiguo y de moderno, Prometeo refleja la proteica fisonomía de su animador. Así vemos a éste despojarse de los influjos finiseculares, del pesimismo novecentista, de la facundia demagógica de sus primeros libros, para adoptar sucesivamente modos más libres y ligeros, imitados del danzante torbellino atómico ${ }^{10}$.

En las páginas de Prometeo aparecen, efectivamente, so„soras proclamas y manifiestos, "encíclicas y estéticas pastorales", como las llamaba Gómez de la Serna "11, además de dra-

10 Cansinos-Asséns, Rafael, "El arte nuevo...", Cosmópolis, I, núm. 2, febrero, 1919, pág. 262.

"A Gómez de la Serna le gustaba emparentar el arte con las formas religiosas. Cf. en Poinbo, los ritos que cumplian los contertulios de esta "sagrada cripta", y la terminología eclesiástica con que se los designaba.

EL ULTRAISMO. - 2 
mas, ensayos, y otras obras de Ramón ${ }^{12}$, que se publicaban en cada número.

En 1909, en el número 5, aparece "El concepto de la nueva literatura" (Memoria leída en el Ateneo como secretario de li. teratura), que fue publicada también separadamente. Esta lleva por lema: "¡Cumplamos nuestras insurrecciones!".

En el número 6 (1909), aparece "Fundación y manifiesto del Futurismo" por Marinetti, traducido por Gómez de la Serna.

En el número 13 (de 1910), "Mis siete palabras (Pastoral)". Alli Ramón protesta contra todos los convencionalismos sociales y dice: "¡Oh si llegara la posibilidad de deshacer!". palabras que son un antecedente del afán destructor dadaísta.

En el número 20 (1910, págs. 519 a 53I), aparece la "Proclama futurista a los españoles", por F. T. Marinetti, escrita expresamente para Prometeo y traducida por Gómez de la Serna. Tiene un sentido más bien político y exhorta a los españoles a combatir "la más grande de las epidemias intelectuales : el arcaísmo...", el culto al pasado (pág. 529). Esta proclama está precedida por otra de Tristán (págs. $517-5 \times 8)$ (seudónimo de Gómez de la Serna) que reproducimos en el apéndice de documentos y que expresa'y anuncia en España, con muchos años de anticipación, el espíritu y la forma de los manifiestos ultraístas posteriores. Pero mientras que éstos se limitan a lo literario, el de Tristán, por influjo de Marinetti, se extiende a otros ámbitos:

¡Futurismo! ¡ Insurrección! ¡Algarada!... ¡Antiuniver. sitarismo!... | Secularización de los cementerios! ${ }^{13}$.

12 Torrente Ballester observa que es Gómez de la Serna el "Ramón" por antonomasia pues sus contemporáneos: Ramón Pérez de Ayala y Ramón del Valle-Inclán eran nombrados, el uno, Don Ramón, el otro, Pérez de Ayala. Cf. Panorama de la literatura española contemporánea, Madrid, 1956, pá-. na 303.

13 En Ismos (Madrid, I93I), pág. I13, nos dice Gómez de la Serna refirién- 
Vemos a través de este breve resumen del contenido de Prometeo que puede ser considerada precursora de las revistas ultraístas.

Las primeras obras de Gómez de la Serna, desde Morbideces (1908) hasta El libro mudo (1910) y Tapices (1913), revelan también su anhelo de avanzar a toda costa. De su Primera proclama de Pombo, nos dice Guillermo de Torre: "sonoro petardo subversivo, donde chisporrotean sus más acres invectivas contra el público y contra las jerarquías establecidas" ${ }^{14}$.

Pero nos importa considerar sobre todo sus Greguerias. La greguería aparece en todos los escritos de Gómez de la Serna, no ya sólo en sus colecciones de ellas, sino también en su teatro, novela y crítica. El mismo Ramón nos ha dado la fórmula : "humorismo + metáfora = greguería". Más explícita es la definición que da Torrente Ballester:

La greguería es el resultado de una intuición que adivina la singularidad absoluta de los objetos y la expresa en un aforismo por medio de una comparación, de una imagen o de una metáfora sustantiva o adjetiva, destacando ante todo el matiz humorístico del objeto ${ }^{15}$.

Con una mirada agudísima, con una observación prodigiosa, Gómez de la Serna penetra un detalle insignificante y le .confiere un valor insospechado. Establece ingeniosas relaciones y las expresa con recursos más propios de la poesía que de la prosa : la imagen o construcciones afines. Quiso según él mismo nos dice, "fumigar la naturaleza con imágenes nuevas" ${ }^{16}$.

dose a esta proclama: "Hoy, a mí mismo me dan no sé qué estas palabras, porque me las he encontrado repetidas demasiadas veces durante estos veintiún años, y que (sic) son como un nuevo tópico, deleznable como todos los tópicos".

14 Op. cit., pág. 44.

15 Op. cit., págs. 303 y 304 .

16 Gómez DE LA SERna, Ramón. Crítica al libro Maelstronı de Luis Cordoza y Aragón, en Alfar, núm. 58, La Coruña, 1926, pág. 33. 
Todas estas peculiaridades relacionan la greguería -y el estilo en general de Gómez de la Serna- con las literaturas de vanguardia. Veremos que el ultraísmo se caracteriza entre as cosas, por el culto a la imagen, por la tendencia a la evan y al juego, la exclusión del mundo sentimental y heroico. logro ingenioso, la intrascendencia del arte, el humorismo. ás aún: muchos poemas ultraístas, al no tener un nexo teítico o sentimental, al ser sólo un collar de imágenes ingeosas, parecen una colección de greguerías.!

Veamos algunas greguerías, hermanas de las imágenes ulaístas:

El jardín se fuma en pipa las hojas caídas.

El arco iris es la cinta que se pone la naturaleza después de haberse lavado la cabeza.

Las últimas estrellas que se apagan son los faroles de los serenos. El alba sopla y los apaga.

En otoño debian caer todas las hojas de los libros.

El dios trabajador y madrugador de los campos pone en hora todos los días al gallo de corral, como a un reloj despertador de precisión.

Alguna estrella está llena de sueño y se la ve cerrar los ojos ${ }^{17}$.

Comparemos estas greguerías con algunas imágenes ultrais. tas:

$$
\begin{aligned}
& \text { Enlazadas del talle } \\
& \text { las horas se deslizan } \\
& \text { por el skating de la mañana }
\end{aligned}
$$

(Pedro Garfias: "Sol")

17 Estas greguerias han sido tomadas de Greguerias selectas, Madrid, 1919. Las dos primeras aparecen transcritas en Díez-Echarri y Roca Franquesa: Historia de la literatura española e hispanoamericana, Madrid, 1960, pág. 1284. 
La campana

tañe su dolor

en el patibulo del campanario

(Humberto Rivas: "Iglesia")

Las nubes son pompas de jabón

(Eugenio Montes: "La Luna")

Los espejos son lagos

puestos en pie

(J. Rivas Panedas: "Café")

Las acacias peinadas

a media melena

(Eugenio Montes: "Five o'clock tea")

$Y$ asi podríamos multiplicar los ejemplos de imágenes, metáforas o comparaciones que constituyen la principal meta de los experimentos ultraístas y que tienen evidente parentesco con las prismáticas greguerías ramonianas, aunque la estructura. de unas $y$ otras no siempre sea idéntica.

Con respecto a las relaciones personales de los ultraístas con Gómez de la Serna, observamos en primer lugar que éste colabora casi continuamente en las revistas del movimiento: las greguerias y la prosa humorística, generalmente bajo el título de "Ramonismo", aparecen con regularidad en Grecia, Ultra y Tableros.

Sin embargo la amistad sufrió algunos altibajos, a juzgar por artículos aparecidos en dichas revistas ${ }^{18}$. Estas divergen-

18 Cf.: Clibero, Antonio M.. "Notas bibliográficas: Pombo y Muestrario de Ramón Gómez de la Serna" en Grecia, núm. XXVI, año II, Sevilla, rgrgr página 14 .

Rivas Panedas, J., "Nosotros los de Ultra" en Grecia, núm. XXV, año II, Sevilla, 1919, pág. I4.

Ambos niegan rotundamente toda posible influencia de Gómez de la Serna. 
cias nacen, probablemente, de la rivalidad que surgió entre la tertulia de Pombo y la de Cansinos-Asséns en el café Colonial ${ }^{19}$.

Sin embargo con posterioridad continúa la colaboración y amistad.

Guillermo de Torre reconoce ampliamente, como ya hemos visto, su papel precursor y agrega:

- Gómez de la Serna ha guardado siempre algún contacto con las vanguardias en general y particularmente con el ultraismo ${ }^{20}$.

Juan Ramón Jiménez

Los rasgos que justifican la consideración de Juan Ramón liménez como un precursor del ultraísmo, son menos evidentes que en Gómez de la Serna. Sin embargo los ultraístas se refirieron en varias ocasiones al autor del Diario de un poeta recién casado atribuyéndole, aunque con restricciones, este valor. Ante el propósito de barrer con todo lo que se consideraba caduco en arte, es la de Juan Ramón una de las pocas figuras que permanecen respetadas ${ }^{21}$.

Podriamos rastrear en la poesía de Juan Ramón, aun por el camino del modernismo, ciertas actitudes y procedimientos que anuncian en alguna medida a la lírica de vanguardia. Hay en él una tendencia a poner el arte sobre la vida $y$ un acen-

19 Estas rivalidades son descritas bajo nombres simbólicos en El Movimiento V. P., novela de Cansinos-Asséns (Madrid, Mundo Latino, s. f.). Cf. capítulos XI y XVII.

20 Op. cit., pág. 45.

21 Cf. : Cansinos-Asséns, Rafafl, "El arte nuevo. Sus manifestaciones entre nosotros", en Cosmópolis, l, núm. 2, 1919, págs. 262 y sigs. La nueva literatura, tomo III. La evolución de la poesia (1917-1927). Madrid, 1927, págs. 17t y siguientes.

TORRE, GUILLERMO DE, Op. cit., págs. 42 y 43.

Chabrs y Marti, JUan, Vuelo y estilo, Madrid, 1934, págs. 152-153. 
tuado individualismo, pero éste tiene un sentido aristocrático que en los ultraístas generalmente falta. Encontramos un uso cada vez más frecuente de imágenes (Se paraba / la rueda / de la noche, "Alba") y de procedimientos que responden a una actitud irracionalista, por ejemplo la "imagen visionaria conti. nuada", en la que el plano real se pierde de vista y se intro. ducen elementos que sólo se justifican por la imagen misma:

De pronto, sol, te yergues,

fiel guardián de mi fracaso,

$y$ en una algarabia ardiente y loca

ladras a los fantasmas vanos.

("Convalecencia", de Estio, 1919)

Compárese este ejemplo con el siguiente fragmento de $\mathrm{Ha}$ llali, de Vicente Huidobro:

\section{$Y$ tal vez mejor que un perro \\ Vigila el cañón \\ Algunas veces \\ El ladra.}

Pero más que en detalles o en rasgos de estilo, podemos considerar a Juan Ramón Jiménez como un precursor del ultraísmo en tanto que hay en él una preocupación por renovar la poesía, por desnudarla de elementos extra-poéticos, de los oropeles modernistas. En las palabras preliminares del Diario de un poeta recién casado (I9I7) nos habla de "necesarias novedades". Luis Cernuda comenta esta frase:

Jiménez, que a pesar de su aislamiento tuvo buen olfato para husmear los cambios de gusto en la opinión literaria, acaso vio en el ultraísmo... una indicación de que el modernismo y las exquisiteces fin de siglo tocaban a su término. 
Hay en el Diario, aunque sólo sea ocasionalmente, algo que marca en su autor noticia del ultraísmo ${ }^{22}$.

En una carta abierta dirigida a Reflector (núm. I, noviembre 1920) Juan Ramón expresa su voluntad de romper con sus "compañeros de generación, secos, pesados, turbios y alicaídos" 23 .

Pero este deseo de renovación, de originalidad, de depuración, responde en el poeta andaluz a una búsqueda insaciable de belleza, a un refinamiento extremado, a una preocupación por su obra, a una voluntad de forma. Hay un predominio del tono melancólico. Los ultraístas en cambio acometen la empresa renovadora con espíritu juvenilmente irresponsable, deportivo, humorístico y vital, y se proponen destruir al modernismo con las ruidosas armas que se importan del extranjero.

22 Estudios sobre poesía española contemporánea, Madrid, 1957, págs. 130 131.

23 Citado por Guillermo DE TORRE, Op. cit., pág. 4I. 
Capítulo 11

\section{DESARROLLO HISTÓRICO DEL MOVIMIENTO}

LOS COMIENZOS

Dos hechos acaecidos en 1918 contribuyen a la aparición del ultraísmo en España. El primero, el paso del poeta chileno Vicente Huidobro por Madrid. Cansinos-Asséns nos habla, al final del mismo año, de este acontecimiento:

Para los que en arte estimamos sobre todo la labor nueva nacida del ansia de acomodarse al ritmo cósmico con que las eternas apariencias cambian de forma, la obra de iniciación que enseña un nuevo modo de belleza, el acontecimiento supremo del año literario que ahora acaba, lo constituye el tránsito por esta corte del joven poeta chileno Vicente Huidobro, que a mediados de estío llegó a nosotros, de regreso de París, donde pudo ver las grandes cosas de la guerra y alcanzar las últimas evoluciones literarias. Pocas líneas en nuestra Prensa señalaron la estancia del original cantor, que, retraído y desdeñoso, sólo se comunicó con unos pocos para anunciarles sus primicias nuevas. $Y$, sin embargo, su venida a Madrid fue el único acontecimiento literario del año, porque con él pasaron por nuestro meridiano las últimas tenden- 
cias estéticas del extranjero: y él mismo asumía la representación de una de ellas, no la menos interesante, el creacionismo, cuya paternidad compartió allá en París con otro singular poeta, Pedro Reverdy, el autor de Les ardoises $d u$ toit, y cuyo evangelio práctico recogió en un libro, Horizon carré (París, I917) '.

\section{Y agrega más adelante:}

Huidobro nos traía primicias completamente nuevas, nombres nuevos, obras nuevas: un ultramodernismo. Desdeñando a los doctores del templo, el autor de Horizon carré se limitó a difundir la buena nueva entre los pocos y los más jóvenes, en paseos y reuniones sedentes, de un encanto platónico, en que la novísima tendencia lograba la fijación de sus matices. De esos coloquios familiares, una virtud de renovación trascendió a nuestra lírica : y un dia, quizá no lejano, muchos matices nuevos de libros futuros habrán de referirse a las exhortaciones apostólicas de Huidobro, que trajo el verbo nuevo. Porque durante su estancia aquí, de julio a noviembre, en que tornó a su patria chilena, los poetas más jóvenes le rodearon $y$ de él aprendieron otros números musicales $y$ otros modos de percibir la belleza ${ }^{2}$.

Guillermo de Torre, con la minuciosidad de quien evoca lejos de la patria, describe la casa del viajero, donde transcurrían las veladas: "aquel departamento amueblado de la plaza de Oriente, casi esquina a la calle Felipe V'y al teatro Real, dando frente a la plaza en cuyo centro galopa Felipe IV sobre un pedestal..." 3 .

1 CANSINOS-ASSÉnS, RAFAEL, La nueva literatura, tomo III, La evolución de la poesia (1917-1927), Madrid, 1927, pảg. 195.

2 Cansinos-Assténs, Rafael, lbid., págs. 196-197.

3 TORRE, GUILLERMO DE, Guillaume Apollinaire. Estudio preliminar y páginas escogidas, Buenos Aires, 1946. pág. 19. 
Y nos habla luego de la trascendencia de estas reuniones:

De boca de Huidobro oí algunos de los primeros nombres verdaderos que iban a definir la época amaneciente; en su casa vi los primeros libros y revistas de las escuelas que luego darían tan pródigas y discutidas cosechas. Alli, en casa de Huidobro, o por mediación de éste, conocí a algunos artistas extranjeros, supervivientes del naufragio europeo, que habían logrado hacer escala en Madrid.

En primer término, a los esposos Delaunay, Sonia y Ro. bert; luego a un grupo de pintores polacos Wladyslaw Jahl. Marjan Paszkiewickz... Alli se incubó originariamente el óvulo ultraísta, entre los contertulios españoles... ${ }^{4}$.

El tránsito de Huidobro por Madrid fue, pues, la primera semilla. Pero es un pequeño acontecimiento, un diálogo de café transformado en "interview", el que prepara el nacimiento "oficial" del ultraísmo, es decir, su constitución como grupo ".

En los últimos meses de 1918 un grupo de adolescentes con inquietudes literarias se reunía en el café Colonial, en torno a Rafael Cansinos-Assén..

Cansinos-Asséns era figura conocida en los medios literarios. Una obra, ya entonces rica, de creación y crítica literaria, su enorme erudición y poliglotismo, su colaboración como crítico literario en La Correspondencia de España, El Imparcial y otras publicaciones, su palabra fácil, metafórica y encendida, hacian de él una figura prestigiosa que atraía a los jóvenes. Cansinos es sevillano. Todos los retratos literarios que de él hemos encontrado ${ }^{6}$ destacan su gran altura y el aire oriental,

4 TORRE, Guillermo DE, lbid., pág. 20.

5 Existian precedentes aislados, por ejemplo las inquietudes renovadoras de Guillermo de Torre, pero nos referimos aquí al nacimiento del ultrásmo como movimiento.

6 Cf. Gómez de la Serna. Ramón. Pombo (la sagrada cripta de Pombo), Madrid, 1918 (pág. sin numerar). 
indolente y melancólico de su figura y carácter, rasgos de gran rabí o de apóstol, de "santón pagano y estatua triunfante del sur" ?. Tenía, nos dice González-Ruano, "una actitud indecisa entre el lirismo desbordante, judáico, y la zumba andaluza, que permitía con dificultad saber cuándo hablaba en serio y cuándo se tomaba el pelo a sí mismo" ". Y más adelante agrega :

Había en su persona una intención desgalichada... Hablaba pomposo y lento, con palabra elegida y párrafo largo, como su prosa; dejo muy andaluz, perezoso y a la vez, inflamado. Era millonario en metáforas, de una imaginación sin límites ${ }^{9}$.

Cansinos cultivaba la costumbre, tan española, de las tertulias literarias ${ }^{10}$. Es precisamente éste uno de los temas de sus libros: la idea del "convivio", con reminiscencias socráticas y matices religiosos de cenáculo, y la del maestro aguijoneando

TORRE, GUILlermo DE, Las metamorfosis de Proteo, Buenos Aires, 1956. págs. II6 y sigs.

González-Ruano, CÉsar, Siluetas de escritores contemporáneos, Madrid. 1949. págs. 13I a 133.

González-Ruano, CÉsar, Mi medio siglo se confiesa a medias. Memorias, Barcelona, 195I, págs. 91 y sigs.

Cf. además las descripciones y alusiones de sus discípulos que aparecen a lo largo de las publicaciones ultraistas. Oportunamente citaremos algunas.

7 Cubero, Antonio, "Los únicos de nuestra atención" en Grecia, número XXIV, año II, 1919, pág. 14.

8 Gonzalez-Ruano, CÉSAR, Siluetas de escritores contemporáneos, Madrid. 1949, pág. 132.

9 González-Ruano, César, lbid., pág. 133.

10 Se trataba en realidad de una tertulia infra-literaria, dada la heterogeneidad social y los escasos méritos literarios de las personas que alli, por lo general, acudian. Cansinos no supo rodearse de jóvenes realmente prometedores. También en sus obras críticas prodigó elogios a figuras secundarias y $\sin$ valor. Tuvo tertulia desde 1905 hasta la guerra civil. 
vocaciones juveniles, abriéndose a los autores desconocidos ${ }^{11}$. La sencillez de Cansinos, que lo hacía accesible a quien quisiera acercarse y su prestigio, atrajeron a su alrededor a un grupo de jóvenes, muchos de ellos sin más mérito literario que el de borronear papeles. Algunos habían hecho ya su "debut" literario en la revista Los Quijotes, precursora de las revistas ultraístas y en la cual colaboraba también Cansinos ${ }^{12}$.

El lugar de reunión era el café Colonial. "Este -nos cuenta personalmente Cansinos- era un café muy bonito, que fue destrozado durante la guerra civil. Iban a él "cupletistas", actores, actrices, literatos... No se cerraba nunca; no tenía más pausa que el tiempo dedicado a la limpieza por la mañana muy temprano. A esa hora volvíamos a nuestras casas. fbamos alli atraídos por las mujeres bonitas, por los hombres ingeniosos y por el ambiente agradable del café, con sus luces, sus espejos y sus divanes rojos, semejantes - según la comparación de Eugenio Montes- a elefantes indios con rojas gualdrapas" "is. En este escenario, en las tertulias de los sábados, fue afirmándose el anhelo de renovación literaria, ya acicateado por el viaje y obras de Huidobro. Alli hizo Xavier Bóveda una entrevista a Cansinos-Asséns que fue publicada en El Parlameniurio:

Nos citamos en el Colonial y en la noche de nuestro sá. bado.

Cansinos, como siempre, fue puntual a la cita.

Con él hablamos de diversas cosas, $y$, sobre todo, de literatura.

1 C.. Cansinos-Assténs, $E l$ divino fracaso, Madrid (s. f.).

12 Cf. más datos sobre esta revista en el capítulo sobre publicaciones ultraístas.

13 Hay muchas alusiones a estos divanes en los poemas de los nuevos poetas. Vando-Villar les dedicó una: "El diván del ensueño". Apareció en Grecia, núm. XVIII, 1919, pág. 10. La transcribimos más adelante. 
Como nuestros lectores saben, Rafael Cansinos-Asséns es hoy el más ameno y admirable de los críticos literarios.

Sus artículos de La Correspondencia de España son comentadísimos.

Su estilo, su novísimo modo de ver las cosas, su grandiosa cultura y su talento enorme, valiéronle la estima y ad. miración de todos...

Todo lo disculpa, todo lo perdona, por todo transige... menos por lo viejo.

Lo viejo es su obsesión, su pesadilla, su tormento.

Quiere hacer cosas nuevas, atrevidas, valientes, desunidas de todo prejuicio académico o moralista: cosas sinceras, rudas, si se quiere, pero nuevas, sinceras..., cosas que estén en el espiritu de nuestro tiempo.

- Hay que ser ultrarromántico - nos dice a todas horas-. Hay que ser de este siglo...

Nosotros le oímos encantados.

La conversación de Rafael es siempre cariñosa y comprensiva. Jamás se pone ni se puso nunca en esa posse despreciable, doctoral y absurda, de los críticos a la antigua. Más que con el crítico, creemos estar hablando con el compañero, con el amigo, con el hermano.

Muy pocas veces le vemos. Tan pocas que únicamente en la noche de "nuestros sábados" le miramos de cerca.

Rafael acude alli, a nuestro café, y sienta en nuestro diván su gran cuerpo indolente, de oriental fatigado, y con sus ojos tristes que más que ver, adivinan, mira nuestras cosas.

Sin que él lo esperara, este sábado le preguntamos:

-Rafael ¿qué opina usted acerca del porvenir político $e$ intelectual de España?

No tardó en con'estarnos:

-Opino...

$\mathrm{Y}$ he aquí, tomado al vuelo, cuanto él nos dijo:... 
- Creo que el porvenir intelectual reside únicamente en la poesía ultrarromántica. Todo lo demás es viejo, viejo, viejo. Tiene ya las barbas blancas y le llegan hasta los pies. La poesía debe desprenderse en absoluto de la retórica, y la oratoria sobre todo. La guerra no influyó absolutamente nada en nuestra literatura. Estamos igual que en el novecientos. Sigue siendo la misma novedad la novedad de entonces, o sea el modernismo, no aceptado por la gente no literaria.

Y no tan sólo no avanzamos sino que más bien parece que retrocedemos. Los maestros van haciéndose más románticos cada vez. Y lo triste está en que los nuevos les siguen.

La salvación reside en aceptarlo todo: todo lo que venga, lo que sea nuevo ${ }^{14}$.

Y después de hacer consideraciones sobre la literatura fuera de España, en su relación con la guerra, agrega :

Lo que hay que hacer es anudar de nuevo los hilos que rompió la guerra, los hilos de difusión que se habían lanzado y entrecruzado de un extremo a otro del mundo como una apoteosis de cintas enlazadas: porque hasta el bolchevismo de ahora no es más que un retorno de las antiguas ideas internacionales...

Aquí estamos todavía en el 900 : el vulgo ingenuo y el vulgo literario no han acabado de entender el modernismo.

Pero a nosotros eso ya nos parece viejo, viejo, viejo.

Tenemos la arterioesclerosis.

14 Bóveda, Xavier, "Los intelectuales dicen. Rafael Cansinos-Asséns" en El Parlamentario, diciembre de 1918. Hemos copiado este articulo de un cuaderno de recortes de R. Cansinos-Asséns. Faltaba en él la fecha. Ante la imposibilidad de dar el dato exacto por no enconysárse El Parlamentario del año 1918 en ninguna de las hemerotecas ni bibliotecas de Madrid, hemos preferido sacrificar por una vez el rigor crítico e incluir esta cita, por el interés que ofrece. 
Ésta es la manera de ser revolucionarios los artistas, por. que estas nuevas estéticas siempre son subversivas $y$ heréticas y atacan al régimen y a la religión; por eso las com. baten los heréticos conservadores. Ellas nos traerán la fraternidad universal, borrarán las fronteras, unirán los corazones en un puro anhelo y comunión de arte. Y, ¿qué es al lado de este sueño la República más avanzada?

La República más avanzada conserva siempre el prejuicio, y éste es - desde el punto de vista artístico- el ripio, el latiguillo, la academia...

Así, pues, adelante siempre en arte y en política, aunque vayamos al abismo.

¿Qué comentario hacer?

Ninguno.

Nuestro espíritu está perfectamente identificado con sus apreciaciones.

Lo viejo debe rehuirse.

Hay que matar -literariamente, señor fiscal一, a Cejador, Cavestany. Cantó... y a todos los que les sigan ${ }^{15}$.

Cansinos incitó en esta entrevista a ser "ultrarromántico"; a dejar el modernismo que ya estaba "viejo, viejo, viejo", con largas barbas blancas, y a buscar la salvación aceptando todo con tal de que fuera nuevo. Había que matar al señor Cejador, al señor Cavestany, al señor Cantó, corderos pascuales que cargaban con las faltas de todos los "arterioescleróticos". Esta entrevista encendió el entusiasmo de los jóvenes contertulios ${ }^{16}$.

15 Bóveda, Xavier: Artículo citado.

16 Guillermo de Torre considera que esta entrevista de Xavier Bóveda en El Parlamentario tuvo menos importancia que la que le atribuimos (- "autor sin prestigio, periódico sin lectores". nos dice). Sin embargo es evidente que a raiz de esta entrevista se redactó el primer manifiesto ultraista, según consta 
Poco después, otoño de 19!18, publicaron en la prensa de Madrid, el primer manifiesto ultraísta, redactado en los siguientes términos :

\section{ULTRA}

Los que suscriben, jóvenes que comienzan a realizar su obra, y que, por eso creen tener un valor pleno de afirmación, de acuerdo, con la orientación señalada por CansinosAsséns en la interviú que en diciembre último celebró con él X. Bóveda en El Parlamentario, necesitan declarar su voluntad de un arte nuevo que supla la última evolución literaria : el novecentismo.

Respetando la obra realizada por las grandes figuras de este movimiento, se sienten con anhelos de rebasar la meta alcanzada por estos primogénitos, y proclaman la necesidad de un ultraísmo, para el que invocan la colaboración de toda la juventud literaria española.

Para esta obra de renovación literaria reclaman, además, la atención de la prensa y de las revistas de arte.

Nuestra literatura debe renovarse, debe lograr su ultra, como hoy pretenden lograrlo nuestro pensamiento científico y político.

Nuestro lema será ultra, y en nuestro credo cabrán todas. las tendencias sin distinción, con tal que expresen un anhelo nuevo. Más tarde, estas tendencias lograrán su núcleo y se definirán.

\footnotetext{
en su mismo texto. Algunos de los firmantes eran ocasionales tertulianos cuyo nombre se borró luego completamente (Fernando Iglesias, Pedro Iglesias Caballero, J. de Aroca). La firma de Guillermo de Torre fue incluida sin previa consulta. Pero este manifiesto es - sin duda- la primera exteriorización pública del movimiento. Así lo afirma también Guillermo de Torre (Cf. Literaturas..., página 46$)$.
}

EL ULTRAISMO. - 3 
Por el momento creemos suficiente lanzar este grito de renovación y anunciar la publicación de una revista que llevará este título de Ultra, y en la que sólo lo nuevo hallará acogida.

Jóvenes, rompamos por una vez nuestro retraimiento $y$ afirmemos nuestra voluntad de superar a los precursores. Xavier Bóveda. - César A. Comet. - Fernando Iglesias. Guillermo de Torre. - Pedro Iglesias Caballero. - Pedro Garfias. - J. Rivas Panedas. - J. de Aroca ${ }^{17}$.

Se había pronunciado pútlicamente la palabra "ultra" que según escribió después Cansinos-Asséns, muchos balbucearon y ninguno llegó a decir ${ }^{18}$. Se había iniciado la bullanguera aventura ultraísta.

El mismo Cansinos nos da su versión, con su característica y trabajada prosa, de esta velada y de las que le siguieron :

17 Prensa de Madrid y en Grecia, núm. XI, año II, Sevilla, 15 de marzo de rgrg, pág. Ir.

18 Cf. "Los poetas del Ultra" en Cervantes, junio 1919, pág. 85. Cansinos reconoce además en este artículo que él mismo había sido incitado a promover esta renovación por el paso de Huidobro por España.

Con respecto al nombre "Ultra", que tan certeramente designa y define al movimiento, Guillermo de Torre discute a Cansinos la paternidad y afirma que fue tomado de uno de los numerosos neologismos que utilizaba en sus trabajos juveniles (Cf. Literaturas..., pág. 47). Lo que importa es, sobre todo, señalar el acierto del nombre. Según Ortega y Gasset, es un hallazgo. Y, lo es, no sólo por su significación dinámica, por designar la búsquedă de un "más allá" en las direcciones estéticas, sino también porque, como véremos, en la lírica de vanguardia, el artista crea ultra-objetos, inventa un mundo más allá del real. '"

Ortega afirma que el hallazgo del nombre es lo único certero del movimiento. Cf. La deshumanización del arte, en Obras Completas, tomo III. Madrid, 1947. pág. 365.

Es interesante comparar esta afirmación de Ortega con la de André Gide: "El día que fue encontrada la palabra DADA, no restó nada por hacer" (CF. ToRRE, GUILLERMO DE, Literaturas..., pág. 183). 
En otoño de 1918, nuestros poetas jóvenes, a semejanza de la estación, quisieron sacudir sus hojas secas. Acaso mi voz, recogida por Xavier Bóveda en los tambores periodísticos, asumiese en esta purificación lírica el sentido de un hálito dispensador. Sobre los divanes que retenian el último césped, bajo los cocos de luz -últimos frutos suspendidos sobre nuestras cabezas - yo mostré a Xavier el espejo de la decrepitud y le descubri entre mis manos temblorosas, esta llama alargada: Ultra. El poeta aceptó este signo de juventud eterna y como un fuego de Pentecostés lo elevó sobre los blancos mármoles. Multiplicado luego el signo ardiente, prestó su llama para los siete lacres rojos que sellaron el manifiesto ultraísta como siete circuncisiones y dejaron caer su esperma abrasada sobre el corazón de nuestro invierno. El mármol que hasta entonces fue un ara se convirtió desde aquel instante en un laboratorio plutónico. Cada sábado contradiciendo la paz de la noche, los poetas trabajaban con dinámico ardor: y nuestros ojos maravillados, veían surgir, de entre sus manos, formas nuevas y sobre todo, bellos regueros de chispas. Los aeroplanos volaban por entre las columnas, astros domesticados se sentaban junto a nosotros, los camareros al dar presión a los sifones salpicaban a la luna. Vivíamos en un ambiente de taumaturgia que, antes de transformar las almas transformaba las cosas. Asistíamos a la ruptura de los cordones umbilicales ${ }^{19}$.

En el año I9.19 encontramos ya al ultraísmo como grupo. como intención colectiva. Los jóvenes escriben afanosamente. buscando las nuevas formas a cualquier precio -incluso el precio del buen gusto y de la poesía- y tratando de aplicar nuevas fórmulas y de sacudirse el lastre modernista. Los poetas,

19 Cansinos-Asséns, Rafael, "Para los Poemas de los pinos, de Xavier Bóveda", en Grecia, núm. XXV, año II, 1919, pág. 11. 
como nos dice Cansinos, "trabajaban con dinámico ardor", en un ambiente de febril taumaturgia. El grupo ultraísta fue ampliándose poco a poco ${ }^{20}$.

El prestigio y ascendiente de Cansinos crecía ante los ojos de sus discípulos y así es frecuente encontrar en las revistas ultraistas poemas, comentarios o dedicatorias que expresan juvenil admiración y que se refieren a las tertulias o a los literarios paseos nocturnos de los sábados. Transcribiremos algunas por su valor de ingenuos documentos, aunque demuestran con frecuencia falta de gusto y de valor poético y tienen una retórica contraria a lo que se buscaba en la nueva poesía:

\section{A RAFAEL CANSINOS-ASSENS \\ El alba del domingo \\ cuando luego \\ de dejarte en tu casa; joh maestro!}

Torno a mi casa solo, embriagado

por la luz de las nuevas ideas...

cuando bien resumida la dulzura

de la noche del sábado,

sintiendo en mis oídos la cadencia

de tus palabras armoniosas,

$y$ viendo ante mis ojos la turbadora gracia

de tus curvas imágenes

torno a mi casa, solo,

pienso hacer un poema,

un poema desnudo,

ultraista,

con lo más intimo y lo más virgen de mi alma...

20 Cf. el capitulo: "Poetas del movimiento". 
Pienso hacer un poema para ti ${ }_{j} O h$ maestro! para decírtelo

en esta hora indecisa del alba 21 .

$Y$ este poema de Vando-Villar nos presenta también a un evangélico Cansinos, oficiando en la noche del sábado sobre "el rojo diván de los ensueños" y ante sus ávidos discípulos:

En la noche sabática,

la dulce hermana del Apóstol

procura que todo le sea alegre

al hermano predilecto y único:

porque él oficiará en esa noche

en el rojo diván de los ensueños.

Alli le aguardan los discípulos,

ávidos de oirle contar

cosas nuevas del Ultra.

En esa hora nocturna y magnifica,

mi alma giróvaga e inquieta

te sigue como si fuese una sombra

a lo largo de las calles amplias,

$y$ tú, oh Rafael lejano, como una abeja lirica,

te paras a cada instante

ante las imágenes que se te ofrecen

como si fuesen perfumadas flores.

22.

Podríamos multiplicar los testimonios de los ultraístas que atestiguan el papel de promotor que tuvo Cansinos-Asséns ${ }^{23}$.

21 Garfias, Pedro, en Grecia, núm. 12, Sevilla, 19i9, pág. 8.

22 "El diván del ensueño", en Grecia, núm. 17, I919, pág. ro.

23 Cf. también "Poemas" de Pedro Garfias, en Cervantes, Madrid, enero ı9r9. "El nocturno lírico" de CORREa-CALDERón, dedicado "a Cansinos-Asséns. 
Hoy se lo reconoce también Guillermo de Torre ${ }^{24}$, que en $\mathrm{Li}$. teraturas europeas de vanguardia quitó relieve a su influencia. También Eugenio Montes en un reciente artículo dice: "...te. nía en su poder un enorme panorama literario que nos fue útil a los jóvenes" ${ }^{25}$. Pero anotemos que la influencia de Cansi. nos fue personal, a través de su palabra, no a través de su obra: el estilo de sus libros no anunciaba para nada al ultraísmo y con posterioridad al nacimiento de Ultra, tampoco cambió st trabajada prosa lírica, aunque hizo, sí, algunos ensayos poéticos en el nuevo estilo, con el seudónimo de Juan Las. Sus relaciones con los ultraístas, posteriormente, sufrieron altibajos. Así lo re. velan muchas páginas de su novela satírica El movimientc $V$. P., que evidencian cierta decepción por el resultado de su! esfuerzos renovadores: por fin el "Poeta de los Mil Años" (Cansinos) decide partir a América con Renato (¿Vicente Huidobro?): allí, sí, la nueva poesía ha dado buenos frutos... ${ }^{26}$.

sacerdote y Maestro de normas", en Grecia, núm. 9. Sevilla, 1919, pág. 8. “Lc más hermoso", de RaFAEL Cansinos-AssÉns (transcribimos los últimos verso: en el apéndice de documentos). BORGES, JORGE LUIS, "A Rafael Cansinos-Asséns" en Poemas, 1923-1953, Buenos Aires, 1954, pág. 86. Vando-Villar, IsaAC, "E apóstol no viene", en Grecia, núm. XIII, año II, Sevilla, 1919, pág. 14. VAN Do-Villar, Isaac, "El divino fracaso", en Grecia, núm. VIII, año II. Sevilla 1919. pág. 15, etc.

24 En Guillaume Apollinaire..., págs, 14, 15 y 16: “...en aquel entonce: -parafraseando levemente la retórica que él usaba - su nombre era luminose e impar en nuestro firmamento. Y lo curioso es que su influjo espiritual ne radicaba propiamente en la obra, sino en su actitud como inductor de entu siasmos cerca de los más jóvenes. Oriundo de otra época, Cansinos-Asséns ad vertía, sin embargo, lúcidamente, que ésta había prescrito, y en vez de atiza carbones desvanecidos se esforzaba por encender luminarias nuevas" (pág. 15)

25 Gómez Santos, Marino, "Pequeña historia de grandes personajes: Eu genio Montes cuenta su vida", en El Pueblo, Madrid, 3 febrero 1960.

26 Cf. El movimiento V. P., Madrid (s. f.). 
El ultraísmo en España dio pocos libros: Imágenes, de $\mathrm{Ge}>$ rardo Diego (creacionista), Hélices, de Guillermo de Torre y algún otro ${ }^{27}$. Será necesario que el movimiento llegue a América para que encontremos numerosos títulos de obras publicadas.

Nos dice Guillermo de Torre que, en la imposibilidad de. realizar libros, los poetas ultraístas fundieron su espíritu de acción en revistas ${ }^{28}$.

La revisión de las publicaciones ultraístas y de sus "allegadas y simpatizantes", es tarea previa indispensable, con frecuencia desconcertante y árida, para quien quiera historiar o conocer el desarrollo de los movimientos poéticos de vanguardia en España. En estas revistas, algunas con nombres que por su clasicismo resultan paradójicos (por ejemplo Grecia y Cer. vantes), la mayoría de ellas hoy perdidas o traspapeladas -especialmente aquellas de vida muy breve : Perseo, Reflector...-, en estas revistas, pues, se guardan las reliquias ultraístas.

\section{Los Quijotes}

Al hablar de Gómez de la Serna señalamos el papel precursor de la revista Prometeo (19o8-1912). En la revista Los Quijotes -anterior al período ultraísta-, se observan también intentos de renovación y encontramos la firma de muchos de los que después, en mayor o menor grado, se adscribirían al ultraísmo. Fue fundada a comienzos de 1915 por Emilio Line-

27 Daremos noticias de ellos en el capítulo sobre los poetas del movimiento.

28 Cf. Literaturas..., pág. 52. 
$\mathrm{ra}^{29}$; ya a fines del primer año aparecen las firmas de Cansinos-Asséns y del joven Jaime Ibarra que colaboraría más tarde en la revista Ultra.

En 1916 encontramos los nombres de muchos colaboradores que pasan luego a Grecia o a otras revistas ultraístas: Juan González Olmedilla, Rafael Lasso de la Vega, Guillermo de Torre -entonces casi un niño-, Lucía Sánchez Saornil (cuyo seudónimo era Luciano de San-Saor), Rogelio Buendía, Eliodoro Puche, Correa-Calderón, Pedro Garfias, César Comet, Xavier Bóveda, José Rivas Panedas y otros ${ }^{30}$. Allí Cansinos-Asséns publicó algunas traducciones de Reverdy, Huidobro, Roger Allard y Apollinaire.

Los Quijotes se publicó hasta fines de 1918 y su desaparición coincide con la fundación de Grecia a la cual pasaron muchos de los colaboradores de aquélla.

Grecia

GRECIA. Revista de literatura, es la primera que acoge en sus páginas los intentos vanguardistas de renovación poética. No nació ultraísta, pero se convirtió al movimiento tras una etapa de vacilaciones. Pasear la mirada por sus cincuenta números es recorrer gran parte del camino ultraísta. Comienza a aparecer el 12 de octubre de 1918 , en Sevilla, dirigida por Isaac del Vando-Villar; jefe de redacción era Adriano del Valle. Al principio se publicaba quincenalmente. A partir del número

29 Era un impresor.

30 En el capítulo "Poetas del movimiento", daremos noticias de muchos de los colaboradores que nombramos en este capítulo. Algunos tuvieron sólo un efímero acercamiento al ultraísmo. 
14 (30 de abril de 1919) se convierte en decenal. Desde esta fecha figura junto a Vando-Villar como director, un cuerpo de redacción formado por Rafael Cansinos-Asséns, Miguel Romero Martínez ${ }^{31}$, Pedro Raida, Adriano del Valle, Rogelio Buendía y Luis Claudio Mariani.

En el verano de 1920 se traslada la redacción a Madrid. El título Grecia nos habla del carácter rubeniano de la revista en sus comienzos. Aparecía escrito sobre un entablamento griego sostenido por jónicas columnas y esta construcción enmarcaba a una serenísima doncella. El encabezamiento de la primera página evidenciaba más aún el carácter modernista : cuatro oferentes griegas llevando sus cántaros, capiteles de columnas clásicas $\mathrm{y}$, como lema de la revista, unos versos de Rubén Darío:

En la angustia de la ignorancia

de lo porvenir, saludemos

la barca llena de fragancia

que tiene de marfil los remos.

(Véase el grabado n. . I.)

Anotemos que estos dibujos de tema griego y el lema rubeniano siguieron apareciendo aún mucho tiempo después del cambio de orientación de la revista, en franca contradicción con su contenido, cuando ya se combatía con mordacidad a los epígonos del modernismo.

Sólo en su tercer año de vida, cuando ya aparecía en $\mathrm{Ma}$ drid, se modificó la presentación y se la reemplazó por un moderno grabado. En el artículo inicial: "Nuestras Normas", Adriano del Valle, por Grecia, expone los propósitos y orientaciones $y$ dice:

En nuestro sueño - pues que sueño es toda obra de juventud, y ésta lo es- nos ponemos bajo la advocación de Ru-

31 Era un erudito sevillano. 
bén, el Panida de los liróforos celestes como él mismo coronó a Verlaine, el sátiro griego de la Galia, y su Programa matinal será la norma de nuestras aspiraciones ${ }^{32}$.

El estilo de toda esta presentación es refinadamente modernista. Poco a poco se va realizando la transformación, aunque al comienzo de un modo muy indeciso. En el número 5 (15 diciembre de 1918), a continuación de un cuento de Rubén Darío (!) aparecen, por primera vez, unos poemas de CansinosAsséns, bajo el epígrafe: "Los Poemas del Ultra". En uno de ellos, "El nuevo arte", anuncia su despertar a una nueva estética :

El poeta de cuarenta años, estaba sentado, al borde de la mesa

Estaba asi sentado para siempre, tendido como una laguna: mas de pronto, de pronto se levantó... y fue terrible sentir crugir (sic) sus huesos...

Parecia ir a dormir ya su sueño en el sepulcro... que no tornaría más...

Pero él se erguía para ir hacia la vida, para buscar en ella las antorchas que brillaban en los espejos y sacarlas de estas sus aguas frías; para ver nacer la aurora que alboreaba en los espejos $y$ lavarse toda la antigüedad con el rocío del alba...

32 En Grecia, núm. 1, 1918, págs. 1 y 2. 
Su corazón temblaba en una gran congoja;

sentia la inquietud de las aduilteras:

y la gravidez de un canto nuevo.

Dijo, "Ultra", éste será mi arte,

cantar este deslumbramiento,

que me toma atónito y ávido,

me encadena y me lanza,

como a una gran cosa que vibra;

cantar el más allá, que yo presiento

en mi pecho que angustia el porvenir:

contarlo todo esto, irradiarme,

multiplicar mis cuarenta años,

cantar esto tan sólo,

esta inquietud extática,

las sonrisas que me laceran,

las miradas que me arrastran,

cual si yo fuese el tiempo,

irradiarme como la gran glorieta

traspasada,

aunque deba caer

para siempre,

desde el alto Viaducto, con los miembros

abiertos en pétalos maravillosos ${ }^{33}$.

En los otros poemas: "La glorieta incitante" y "El Viaducto ávido y quieto" aparecen términos y temas gratos a los ultraístas: "grandes ómnibus". "vida múltiple". "luces eléctricas", "nubes acribilladas"...

En el número 7 (15 enero de 1919) se publican, por primera vez en Grecia, poemas de Vicente Huidobro.

Poco a poco las colaboraciones ultraístas y las traducciones de vanguardistas europeos (Max Jacob, Apollinaire, Marinetti,

33 En Grecia, núm. 5. año I, 15 dic. 1918, págs. 6-7. Cansinos expresa aquí su intención renovadorn, pero no utiliza las nuevas formas. 
Paul Morand, Tristan Tzara, Reverdy, Paul Dermée, Picabia, André Salmon, Cocteau, Cendrars, Soupault, etc.), se van haciendo más frecuentes. Es importante destacar la presencia de estas traducciones, acompañadas casi siempre de estudios críticos, pues las revistas ultraístas realizaron una importante labor de difusión de las estéticas de vanguardia europeas y especialmente francesas.

Algunos jóvenes confiesan sus luchas entre el apego a las anteriores formas y el ingreso al ultraísmo. Cuesta desprenderse del hombre viejo. Pedro Garfias nos dice: "Me he sacudido mi romanticismo..." ${ }^{34}$ y Pedro Raida confiesa que tuvo que vencer dudas y vacilaciones antes de decidirse a cambiar los versos de la Eneida por la inspiración de los automóviles, los aeroplanos, las dinamos y el exprés ${ }^{35}$.

En el número II (15 de marzo de 1919) aparece el "Manifiesto Ultra" que ya había sido publicado en la prensa de Madrid a fines de $1918^{36}$.

Otra confesión de un nuevo converso al ultraísmo aparece en el número I3, del 15 de abril de I9I9. Se trata del "Scherzo ultraísta, Op. II", de Miguel Romero y Martínez, que anuncia propósitos del "arte nuevo":

Quiero con vosotros los Fuertes, que formáis la vanguardia del Arte, luchar por los ideales himmanos, caldear mi frase en el hogar de la vida, exaltar el florecimiento de la carne, distenderme, multiplicarme,

34 En Grecia, núm. 10, 1919, pág. 15.

35 Cf. "Confesión", en Grecia, núm. 14, 1919. Pedro Raida carecín de cualidades poéticas. Sus frecuentes colaboraciones en Grecia son índice de la heterogeneidad de la revista y del movimiento.

36 Cf. más arriba, pág. 33 . 
adivinar la ignorada fragancia

de los frutos que aún oculta la tierra, fascinarme ante el misterio de las nebulosas

$e$ intuir los secretos del cielo,

ser el cable que traiga

nuevos soplos divinos

a la demiurgia de la Palabra, oxigenar y desanquilosar el Parmaso, combatir la endemia de Doina Academia, emplear galicismos y neologismos, odiar el eunuquismo de los pedantes $y$ el mimetismo y el onanismo de los poetastros, aventar las cenizas novecentistas, cantar el automóvil con Marinetti, olvidar la undecasilabia de Stecchetti, bucear en el océano del futurismo y punzar la medula de los catadores de la pura belleza con escalofríos del áureo Mañana, con las vibraciones del Presentimiento - le frisson, l'extase-, con las violetas de la luz del Alba.

Quiero sumar mi sangre, mi cerebro y mis misculos al certamen generoso del Ultra; aportar mi arcilla o mis mármoles para el Neopartenón de la gloria; ¡ser en las letras, como vosotros, un bolchevique! 37 .

Romero y Martínez proclama muchos rasgos del ultraísmo: afanes iconoclastas, ser un bolchevique en las letras, adaptar la poesía al nuevo mundo y saber encontrarla en su exprés o en

37 En Grecia, nún. 13, 1919, págs. 1 y sigs. 
un avión, crear nuevos mundos con la palabra, emplear neologismos y galicismos, aventar las cenizas novecentistas...

Los cantos al tranvía, al automóvil, al aeroplano y otros temas ultraístas surgen ya a cada paso. Los redactores nos cuentan humorísticamente que reciben anónimos y soportan la incomprensión de los "momificados" amantes de la tradición ${ }^{38}$.

El número 16 , del 20 de mayo de 19.19, marca dos importantes apariciones: la de Gerardo Diego y la de Guillermo de Torre. Nos dice Joaquín de la Escosura que Guillermo de Torre se había abstenido de colaborar antes, hasta la total metamorfosis de la revista ${ }^{39}$. Era Guillermo de Torre, en aquellos años de juventud, un entusiasta luchador por la causa del Ultra y defensor de su ortodoxia. Hace su aparición con un "Friso ultraísta", con todos los rasgos de su nuevo estilo.

En el número 24 (ro de agosto de 1919) comienza a publicar en Grecia, Juan Larrea.

A partir del número 27 (20 setiembre 1919) encontramos colaboraciones de Rafael Lasso de la Vega. Desde agosto de 1919, aparece la prosa de Gómez de la Serna. Merece destacarse también la colaboración de artistas plásticos.

No queremos seguir detallada y exhaustivamente la marcha de Grecia, sino sólo anotar los puntos claves de su evolución que ayudan a comprender la historia del movimiento.

En octubre de 19.19 cumple Grecia su primer aniversario. La revista festeja su cumpleaños, publicando un artículo de Vando-Villar, su director, en el que nos hace una entusiasta crónica de su primer año de existencia y alude a la transformación que hizo que cambiaran los helénicos trajes blancos, por la ultraica coraza guerrera. Decía así :

38 Cf. "Arlequiniana", Grecia, núm. 14, 1919. pág. 38, que transcribimos en la página 87 .

39 Cf. Escosura, Joaquín de la, "Guillermo de Torre", en Cercantes, octubre de 1920, págs. 92-93. 


\section{EL TRIUNFO DEL ULTRAISMO}

GRECIA cumple su primer aniversario.

Si algún día me preguntasen cuál había sido el día más feliz de mi vida, sin vacilar responderia : $i$ Oh, el día de la Fiesta de la Raza!

Porque en ese día memorable, f cómo es bello recordarlo! unos cuantos poetas llenos de fe y de entusiasmos en nuestros ideales, como los escultores que descorren la tela que oculta la hermosura de su obra, nosotros, descorrimos la cortina fantástica y anónima que nos cubría, para mostrar nuestro arte balbuciente, lleno de misteriosos temblores y colmado de augurios.

Parecía real y verdaderamente que nuestra modesta $\mathrm{Re}$ vista era el vaso divino donde se conservara taumatúrgicamente el néctar del espíritu ático a través de los tiempos, y nosotros, alborozados, lo escanciábamos con la prodigalidad inefable de nuestra juventud de poetas soñadores e ingenuos. en los primeros números de GRECIA...

Pero he aquí que un dia, el alto espiritu del maestro Cansinos-Asséns, desde la Corte donde reside, nos advierte cordialmente: "Que debemos superarnos y crear un Arte nuevo como la naturaleza crea un árbol" 40. Un Arte nuevo hen. chido como un mar tempestuoso de vibraciones dinámicas.

\section{ULTRA .}

Y nosotros, que hasta entonces, estábamos helénicamente vestidos de blanco, vislumbramos un más allá en la palabra lanzada por el maestro como un grito de guerra y de renovación.

40 Este concepto pertenece a Huidobro. 
Dejamos el nombre de "griegos", con que nos habían signado los hombres sutiles del sur, para trocarlo por el de "ultraistas...".

Algunos creyeron insidiosamente que esta modalidad era un capricho bolchevista y empezaron a escarnecernos de la forma más arbitraria e irrespetuosa, demostrando nuestros enemigos un espiritu farisaico y un desconocimiento profundo de nuestro Arte.

Algunos compañeros se amedrentaron dejándonos casi solos, para seguir cantando sempiternamente a la princesita de los bucles de oro y de las manos de lirios; pero otros, en cambio, nos animaron con sus producciones originales, descubriéndonos asi un nuevo concepto de la belleza y de la es. tética.

¡Nosotros tenemos en nuestras manos el porvenir y una sonrisa de desprecio para nuestros enemigos!...

$$
\begin{aligned}
& \text { [VIVA CANSINOS-ASSÉNS! } \\
& \text { | VIVA GRECIA! } \\
& \text { [VIVA EL ULTRA! }
\end{aligned}
$$

En marzo de 1920 se anuncia la "transmigración" de Grecia, en los siguientes términos:

Como quiera que Grecia es el órgano más autorizado del movimiento ultraísta en España, y esta novísima tendencia literaria tiene cada día mayor importancia, a fin de alcanzar una más amplia irradiación de nuestro arte por todos los ámbitos de la Península, hemos adoptado la firme resolución de editar nuestra revista en Madrid.

41 Grecia, núm. XXIX, págs. I y 2, 1919. No creemos necesario señalar en cada caso la poca calidad literaria de muchos de los documentos transcritos. No era otro el nivel medio del movimiento y ellos dan una visión panorámica de su desarrollo. 
Así pues, mucho lamentamos que, durante algún tiempo, estemos obligados a suspender, siquiera sea momentáneamente, nuestra decenal comunicación con el público, a quien tanta bondad y solicitud debemos.

Pero nuestra interrupción será una cosa breve, durante la cual, introduciremos grandes reformas, al mismo tiempo que será una tregua para recuperar las fuerzas necesarias con que hemos de terminar victoriosamente, la heroica cruzada emprendida contra el pasado, nuestro tenebroso y secular enemigo.

Seguros de que nuestros hermanos en Arte no desertarán jamás de las legiones ultraicas, nos despedimos, fraternal y transitoriamente, hasta la cercana fecha en que celebraremos nuestro triunfo espiritual ante las aras blancas de las noches del sábado.

Amigos: sea este nuestro último grito desde Sevilla : [VIVA EL ULTRA!

Isaac del Vando-Villar ${ }^{42}$.

Grecia aparece, pues, en Madrid, desde el verano de 1920 hasta el $\mathrm{I}^{\circ}$ de noviembre del mismo año, fecha en la cual, al alcanzar el número cincuenta, cesa su publicación. En este último número (que incluía como suplemento el "Manifiesto Vertical", de Guillermo de Torre), al celebrar el segundo aniversario, Vando-Villar anuncia una breve interrupción -que sería definitiva- y hace una especie de balance:

Pero tenemos que hacer constar... nosotros, los que durante un largo periodo llevamos la palabra de ultra sobre

42 "La transmigración de Grecia", en Grecia, nưm. 42, 1920, pág. 9. IL IITRAISMO. -4 
nuestras frentes como un "inri" vergonzoso, que nuestros anhelos de superación no han sido inútiles...

Grecia es una revista heterogénea y dispar. Encontramos de todo en sus páginas, como en el sombrero del prestidigitador: un "mare magnum" casi inclasificable de poemas, traducciones, manifiestos, crónicas de veladas... El ultraísmo, ya de por sí, no es una escuela de direcciones claras, como veremos, sino un movimiento que alberga tendencias dispares. Esta confusión se hace más patente en Grecia, que refleja su etapa de gestación y tanteo. Pero, como dice Guillermo de Torre: "Por encima de sus irregularidades y transigencias, omisiones y confusiones, Grecia es la revista más interesante del primer período y define claramente el carácter y vicisitudes de éste" ${ }^{44}$.

Años después, en junio de 1926, aparece en Sevilla la revista Mediodía, dirigida por Eduardo Llosent y Marañón. La época de los "ismos" ya había pasado y nos encontramos ante una etapa brillante de las letras españolas, ante un deseo de depuración y de forma que Mediodía intenta reflejar ${ }^{45}$. Y aunque los años no han pasado en vano para el logro de la calidad poética, los redactores de Mediodía rinden, en su primer número, homenaje a su hermana y antecesora sevillana Grecia con un artículo al que, como al inaugural de aquella, titulan: "Nuestras . Normas". Reproducimos algunas partes:

43 "La plenitud del ultraísmo. Grecia ha cumplido su segundo aniversario", en Grecia, núm. L, 1920, pág. 5.

44 Literaturas..., pág. 52.

45 A lo largo de sus páginas encontramos colaboraciones de Romero y $\mathrm{Mu}$ rube, Luis Mosquera, José Bergamín, Mauricio Bacarisse, Luis Cernuda, Moreno Villa, Fernando Villalón, Jorge Guillén, García Lorca, Gerardo Diego, Antonio Espina, José M.a Cossío, Vicente Alcixandre, Manuel Altolaguirre, Guillermo de Torre, Rafael Alberti. Pedro Salinas, Carmen Conde, etc. 


\section{NUESTRAS NORMAS}

Bajo estas mismas palabras, en la carilla inicial de una revista de Sevilla, hace ya algún tiempo, se rezó el credo de la disciplina estética más sincera y trascendente que ha germinado en la ciudad de la Giralda. La revista era Grecia y de ello hace siete años.

Fue Grecia, con Cervantes, Ultra, Tableros y los efímeros números de Perseo y Reflector la manifestación difícil de una nueva conciencia artística, tendencia novísima, aunque clásica, dentro de su arbitrariedad desconcertadora. Clásica en el sentido justo que a la noble palabra da el primer lírico español de nuestros días: "clásico" es, únicamente, "vivo".

Desde aquella publicación, para nosotros, en Sevilla no ha habido editorial alguna de puro idealismo literario.

Grecia ha sido, a pesar de sus grandes deficiencias de conjunto, el único fenómeno literario, orientador y noble, que se ha producido en nuestra ciudad. Su ritmo turbulento, epiléptico, de continuada psicosis lírica, respondía a la exacerbación literaria creada por la exacerbación moral de la gran guerra. En un marco de hostilidades enconadas Grecia llegó al mayor éxito a que puede aspirar una publicación de su laya: labró su ambiente. Es decir, alcanzó éxito con las armas más opuestas al triunfo fácil: sinceridad, atrevimiento.

Sevilla adeuda al grupo de liróforos que mantuvieron inextinto aquel fervor, que su nombre vaya unido a una de las épocas más pintorescas y curiosas de la literatura universal: a la gran "época" de los "ismos", etapa de raras germinaciones dolorosas. Ella es la adolescencia de nuestros días traspasada por la inquietud de mil estrellas epifánicas: ella es la nubilidad desnuda y dudosa del arte puro de hoy, pleno, perfecto, conseguido. 
La misma confusión de valores que revistió de aquel matiz turbulento y simpático a la primera época de Grecia, fue más tarde, la causa de su muerte. No supo aquella revista evolucionar, depurarse, vivir cuando una vez quemados todos los cohetes de las primeras noches pirotécnicas y alocadas, había sólo que dar asentimiento en sus páginas a lo puramente creado y conseguido por gracia de arte. Grecia llegó a incidir en un humorismo dudoso, hijo, tal vez, de una amplitud excesiva de concepto, de una imprecisión de normas y fines. El humorismo es fruto de sazón y decadencia : en Grecia - alba de arte- el humorismo era tono de equivocación y fracaso.

Estos son pues los valores de Grecia, "alba de arte".

Cervantes

Cervantes. Revista hispanoamericana, a partir de su segundo año, Revista mensual iberoamericana. Como Grecia, no nació ultraísta. Empezó a publicarse en enero de I916, dirigida por Francisco Villaespesa, Luis G. Urbina y José Ingenieros; Joaquín Dicenta (hijo) figuraba como subdirector. En enero de Ig Ig entra a formar parte del movimiento ultraísta. La dirigió desde esa fecha Rafael Cansinos-Asséns y César E. Arroyo estuvo al frente de la sección americana. Ballesteros de Martos fue su secretario.

En la primera época encontramos, entre los nombres de los colaboradores de Cervantes, a Amado Nervo, José Asunción Silva, Emilio Carrere, Villaespesa, Emilia Pardo Bazán, Unamuno, Pío Baroja. En su segunda época, al cambiar de directores, adquiere un carácter antípoda. Cuando Cansinos-Asséns asume la dirección, anuncia en su "Liminar":

46 Sin firma, en Mediodia, núm. I, Sevilla, 1926, págs. I a 3. 
La Revista Cervantes, cuyas páginas se prestaron siempre a ser moldeadas por las manos juveniles en todos los modelos, será ahora aún más dúctil y flexible para las inspiraciones nuevas. La intención de un ultraísmo indeterminado, que aspira a rebasar en cada zona estética el límite y el tono logrados, en busca siempre de nuevas formas, será la que estas páginas adopten y la colaboración más juvenil - según los tiempos del espíritu- será la que en este edificio de arte hallará la mejor acogida ${ }^{47}$.

En sus páginas encontramos, más o menos, los mismos nombres que en Grecia: P. Garfias, X. Bóveda, A. del Valle, V. Huidobro, Chabás y Martí, A. Espina, C. Comet, E. Puche. G. Diego, E. Montes, L. de San-Saor, J. Larrea, R. Buendía. E. López Parra, Francisco y Guillermo Rello, G. de Torre, P. Raida, J. Rivas Panedas, H. Rivas, R. Lasso de la Vega, etc.

Además se publican antologías de lírica francesa de vanguardia y de poemas expresionistas; artículos críticos sobre estos autores extranjeros y sobre Whitman, Mallarmé, etc.; consideraciones teóricas sobre el ultraísmo, crónicas, polémicas...

Aunque nos parece su contenido más homogéneo que el de Grecia, nos dice de esta revista Guillermo de Torre:

Recoge en dicha etapa, y a través de sus páginas desiguales, llenas, en parte, por una colaboración hispano-americana sin tamiz, interesantes poemas, prosas y críticas de todos los ultraístas, mas sin llegar a establecer las jerarquías necesarias ${ }^{48}$.

47 Cansinos-Asséns, Rafael, "Liminar", en Cervantes, enero 1919, páginas I y 2.

48 Literaturas..., pág. 53. 
Ultra

Los firmantes del primer manifiesto ultraísta se habían comprometido a publicar una revista que se llamaría Ultra, "en la que sólo lo nuevo hallaría acogida" 49.

Se dio forma a este anhelo en enero de 1921.

Ultra (Vltra). Poesía. Crítica. Arte. Este era su título; posteriormente cambió el subtítulo por el de Revista internacional de vanguardia. Se publicó primero decenal y a partir del $1 .^{\circ}$ de diciembre de $192 \mathrm{I}$, quincenalmente. Aparecieron veinticuatro números, el último en febrero de 1922. No figuraba el nombre del director sino esta afirmación: "Ultra no tiene director, se rige por un comité directivo anónimo". Creemos ver en esto una influencia DADÁ, recordemos que los dadaístas afirmaban no tener jefes: "Todo el mundo es director del MOVIMIENTO DADÁ" ${ }^{50}$.

Pero, en rigor, nos confiesa Guillermo de Torre, Ultra estaba "piloteada" por Humberto Rivas y la advertencia del "comité directivo anónimo" era una fantasía ${ }^{51}$.

Los redactores de Ultra nos anuncian en su primer número los propósitos de la revista :

Viene a hacer labor de selección, a recoger lo que hay de valioso y maduro en el espíritu que ha alentado en las revistas Grecia, Cervantes, etc., las cuales deberán considerarse como precursoras ${ }^{52}$.

E invitan a la colaboración:

Hombres rezagados: no dejéis para demasiado tarde el momento generoso de vuestra aportación ${ }^{53}$.

49 Cf. dicho "Manifiesto" que hemos transcrito en las págs. 33-34-

50 Tzara, Tristan, Boletín dadá, núm. 6, Paris.

51 Cf. Literaturas..., pág. 53.

52 Ultra, núm. I, 27 de enero de 1921, pág. I.

53 Ultra, ibid. 
Ultra tiene, en general, los mismos colaboradores que hemos encontrado al recorrer las páginas de las revistas anteriormente analizadas.

La prosa de Gómez de la Serna aparece en casi todos los números y son muy frecuentes también las poesías del argentino Borges.

En Ultra observamos que la relación entre poetas y artistas plásticos es cada vez más estrecha: los polacos Jahl y Paszkiewicz, el uruguayo Barradas y la argentina Norah Borges, ilustran las portadas y el interior de la revista.

Ultra denota mayor selección y homogeneidad en su contenido, es la revista donde mejor concreción alcanzan los móviles ultraístas. Así lo considera Guillermo de Torre:

Pero la revista más típica y netamente representativa del hervor, del radicalismo de esta crepitante $y$ disidente generación es la decenal Ultra, que conquistó una amplia atención y un núcleo escogido de fieles lectores. Singular ante todo por su presentación tipográfica, su formato y sus portadas muequeantes que suscitaban la indignación de los transeúntes y -vengativamente- una de las más bellas glosas d'orsianas ${ }^{54}$.

\section{Ultra de Oviedo}

Otro "órgano de la moderna lírica", aunque de vida efimera, es Ultra de Oviedo. Su título era: ULTRA (VLTRA). Hoja quincenal de literatura. Empezó a publicarse en noviembre de 1919, dirigida por Augusto Guallart. Redactores eran Rafael

54 Literaturas..., pág. 53.

La glosa d'orsiana aludida es "Ultra tiene razón" en el quinto volumen del Nuevo glosario. Poussin y el Greco, Madrid, 1922. La revista Ultra provocó en general carcajadas e insultos, pero tuvo un pequeño público de jóvenes, según afirma también César González-Ruano, en Mi medio siglo se confiesa a ntedias, Barcelona, 1951, pág. 93. 
Cansinos-Asséns, Gonzalo de Alvar, Joaquín de la Escosura Luis Zubillaga, Manuel María Durán y otros.

Su creación es anterior, pues, a la de Ultra de Madrid, aun. que fue mucho menor su repercusión. Grecia, su hermana ul traica, saluda entusiastamente su aparición:

Ultra con Cervantes y Grecia, ha venido a formar el triángulo lírico, como un iris luminoso en la oscuridad del novecentismo.

¡ Hermanos, Hurra por nuestro Ultra! ${ }^{55}$.

Cosmópolis

Aunque no es una publicación ultraísta, es necesario citar además a la revista Cosmópolis por los importantes artículos críticos y ensayos sobre literaturas de vanguardia y específicamente sobre el ultraísmo que en ella aparecen.

Cosmópolis. Revista mensual ilustrada. Madrid.

Fue creada en enero de 1919, dirigida por Enrique Gómez Carrillo, con una intención de acercamiento entre los escritores españoles y los hispanoamericanos.

Aparecen en ella artículos de Cansinos-Asséns, Antonio $\mathrm{Cu}$ bero, Guillermo de Torre, Borges, etc., sobre el arte nuevo. Realiza además una importante labor de difusión de las últimas corrientes literarias francesas.

España

También la revista España. Semanario de la Vida Nacional, aunque no ultraísta, dedicó artículos y publicó algunas poesías de los cultores del arte nuevo. (Su existencia es anterior al ultraísmo, pues comenzó a publicarse el 29 de enero de 1915 en Madrid).

55 Grecia, núm. XXXIl, año I, 1919, pág. 9. 
Las revistas ultraístas que hemos nombrado: Grecia, Cervantes y Ultra, son las más representativas y las que alcanzaron más larga vida.

Aparecieron además otras, de existencia efímera, últimas publicaciones de un ultraísmo que, según nos dice González: Ruano: "se nos moría ya entre las manos" ${ }^{56}$.

Ellas son:

Tableros

TABLERos. Revista Internacional de Arte, Literatura y Critica (Refundición de Grecia). Quincenal. Se publicó en Madrid; el primer número apareció el 15 de noviembre de 1.921; el cuarto y último, el 28 de febrero de 1922. La dirigía Isaac del Vando-Villar y era secretario de redacción I. Gutiérrez Gili.

Encontramos entre sus colaboradores a los mismos citados en las reseñas de otras revistas ultraístas: Guillermo de Torre, A. Espina, Gutiérrez Gili, Borges, Diego, Lasso de la Vega, Gómez de la Serna, Rivas Paneda, H. Rivas, J. Ibarra, Vando-Villar, Luis Mosquera, Buendía, Jahl, Barradas, etc. Además de los poemas e ilustraciones, figuran traducciones, prosa humorística, artículos sobre arte...

De ella nos dice Guillermo de Torre: "revista menos unilateral y expresiva que Ultra y que muere antes de llegar a definir su verdadera fisonomía" ${ }^{57}$.

Perseo

Perseo. Revista iberoamericana. Apareció sólo un número en mayo de 1919. Se publicó en Madrid bajo este mitológico título y con unas arrogantes palabras de salutación. Fue su director Luis Elías y la orientación artística estuvo a cargo de Santiago Vera. Aparecieron en este primero $y$ único número

56 GonzAlez-Ruano, César, Mi medio siglo se confiesa a medias, pág. 93.

57 Literaturas... pág. 53. 
trabajos críticos y literarios: un estudio sobre el arte de Julio Antonio por Santiago Vera, "Andrómeda" por Adolfo Salazar y un artículo sobre las "Novísimas directrices pictóricas. El vibracionismo de Barradas" de Guillermo de Torre. En la parte literaria apareció un conjunto de "Poemas del Ultra" con las firmas de Cansinos-Asséns, Eugenio Montes, Rivas Panedas, Bóveda, etc. Además prosas y versos de Goy de Silva, L. Elías, S. Risco, A. Bello, J. M. Aldama, etc.

Reflector

REFLECTOR: Del "verdaderamente impar y luminoso Reflector", según lo llama Guillermo de Torre ${ }^{58}$ apareció un solo número en diciembre de 1920, en Madrid. Enrique Díez-Canedo hace, en España, esta reseña:

Esos caminos trata de iluminar en nuestro país una revista que sustituye a Grecia con el nombre, mejor coordinado, de Reflector. La dirige un poeta muy joven, José de $\mathrm{C}_{\mathbf{i}}$ ria y Escalante, y es secretario de redacción Guillermo de Torre. Últimamente, hablando de un manifiesto de este bravo campeón, dijimos cuán equivocado nos parecía, y los trabajos que de él publica Reflector, en general, no nos hacen modificar el juicio. Jorge Luis Borges, que tiene talento, ríe las gracias de "Vertical". Hay en Reflector buenos poemas, bue. nas ilustraciones. Hay en Reflector lo que a Grecia le faltaba, con todo lo que Grecia tenía. - Le deseamos vida larga y fecunda ${ }^{59}$.

Pero el buen deseo de Díez-Canedo no se cumplió. La revista no volvió a aparecer. Colaboraron también Juan Ramón Jiménez, Gómez de la Serna, Gerardo Diego, Adriano del Valle, Rivas Panedas, Vighi, Vando-Villar y otros.

58 Literaturas..., pág. 53.

\$9 En España, núm. 294, año VI. Madrid, 1920, pág. II. 


\section{Horizonte}

Horizonte. Arte, literatura, critica. Madrid. Se publicaron cuatro números; el primero el 15 de noviembre de 1922 ; el último, el 30 de diciembre del mismo año. Era quincenal. Sus directores literarios fueron Pedro Garfias y José Rivas Panedas; director artístico: Wladislaw Jahl.

Junto a los nombres ultraístas de Montes, Garfias, Buendía, etc., encontramos ya los de poetas nuevos, que constituirian más tarde el núcleo de la generación del 27: Alberti, Guillén, Dámaso Alonso, García Lorca. Gerardo Diego (que pertenece a ambos momentos). Y junto a ellos, también, nombres de las generaciones anteriores al ultraísmo: Moreno Villa, Antonio Machado, que antes habían estado excluidos de las hojas ultraístas. En una crítica que aparece del libro Hélices de Guillermo de Torre, se juzga al "ultraísmo" como algo ya superado y peligroso ${ }^{60}$.

\section{Vértices y Tobogán}

VÉRTICES y TOBOGÁN, Madrid. La primera aparece en el otoño de 1923, la segunda en agosto de 1924, dirigidas por Manuel de la Peña. Son, según palabras de Guillermo de Torre: "hojas filiales, póstumas y tardías de Ultra" ${ }^{61}$.

Alfar

Alfar. Desde 192 I hasta 1925 se denominó Revista de Casa América de Galicia. En este año cambia su título. Se publicó mensualmente en La Coruña. Desde 1923 hasta 1926

60 Sobre Horizonte dice Cansinos-Asséns: "Nuestros poetas no cuadraban ya su horizonte, y la vieja poesía se les introducia por los puntos baldíos" (alude al título Horizon carré de Huidobrol: La evolución de la poesia, pág. 325.

61 Literaturas..., pág. 54. 
fue su director el cónsul uruguayo Julio J. Casal. En 1927, después de un paréntesis de casi un año, reaparece y cambia de director: Julio González del Valle. Posteriormente se trasladó a Montevideo.

Guillermo de Torre la considera "la más digna y perfeccionada sucesión de las primeras revistas ultraicas, ya que en ella se encuentran las firmas de los más valiosos supervivientes de esa tendencia" ${ }^{62}$.

La revista tiene una magnífica presentación, con numerosas reproducciones de artistas plásticos: Barradas, Vázquez Díaz, Bores, Norah Borges, Juan Gris, Sonnia Delaunay, Pazkiewicz.

Encontramos aún nombres de poetas ultraístas y podemos ir observando su evolución: López-Parra, Diego, Buendía, Adriano del Valle, etc. Los ultraístas argentinos también colaboran.

Pero, evidentemente, los años no han pasado en vano. No quedan ya rasgos de aquella euforia revolucionaria e iconoclasta de las primeras revistas ultraístas. Hay en ésta más dignidad, a pesar de su desorientación, y una abertura a otros poetas, antiguos y nuevos (Guillén, Salinas...). Se publican además artículos críticos.

De esta revista nos dice José María de Cossío:

Primer lazo de unión entre el movimiento ultraista y la mera poesía en trance de germinación es la revista Alfar, que publica en La Coruña el cónsul uruguayo Julio J. Casal. En ella hacen sus primeras armas públicas poetas que habian de alcanzar justa notoriedad junto a otros ya probados y conocidos, o aliados ( $y$ tal vez desertores) del ejército ultraísta.

Precisamente por este criterio amplio tiene esta revista el más alto valor documental, y no es excesivo considerarla como el panorama más cabal de la revuelta vida poética de aquel 
momento. Las vacilaciones, las persistencias, los cambios de rumbo, los nuevos acentos que han de prevalecer, conviven en sus páginas al lado de informaciones de artes plásticas aquejadas en aquellos días de las mismas dolencias y sacudidas por los mismos vientos que las artes literarias. Ha solido llamarse a panoramas como el apuntado desorientación, y no hay inconveniente en admitir la palabra, pero advirtiendo bien claramente que tal desorientación no significa el vagar sin rumbo del que ha perdido el camino, sino el tanteo ansioso de quien quiere trazárselo y seguirlo. Alfar, junto con las revistas madrileñas aludidas ${ }^{63}$ llena el espacio que separa las ya caducadas revistas ultraístas (Cervantes, Grecia, Ultra, Reflector...) con las que inmediatamente van a ir apareciendo ${ }^{64}$.

\section{Otras revistas ultraistas}

$\mathrm{Y}$ por último, para terminar con estas reseñas de las revistas del ultraísmo y de las que en alguna medida están relacionadas con él, nombraremos a Parábola de Burgos y a Ronsel de Lugo.

PARÁbola. Cuadernos mensuales de valoración. Castilla. Empezó a publicarse en junio de I923. Se interrumpió su aparición en el número 2. Reapareció en 1927 hasta 1928. En total, seis números. La dirigió Eduardo Ontañón.

Ronsel. Revista de Arte. La dirigian Correa-Ca'derón y Alvaro Cebreiro. Se publicaba mensualmente, en Lugo, en 1924. Guillermo de Torre la llama "revista gemela de Alfar" 65 .

${ }^{63}$ Se refiere a Indice, inspirada por Juan R. Jiménez, y a otras revistas de provincias.

64 Prólogo a las Poesias de Fernando Villalón, Madrid, 1944, págs. 15 y 16.

65 Literaturas.... pág. 54 . 
Guillermo de Torre incluye además entre las revistas ultraístas -en un reciente artículo ${ }^{66}$ - a PLURAL. Revista mensual de literatura, de la cual no hemos podido consultar ningún número. Aparecieron sólo dos, en Madrid, en enero y febrero de 1925; fuc dirigida por César A. Comet.

Para tener una visión acabada del desarrollo y repercusión del ultraísmo es necesario también consultar las revistas argentinas : Nosotros, Prisma, Martin Fierro, Inicial, Proa, Sintesis... en las que se publican manifiestos, poesias, ensayos sobre ultraísmo. Su análisis, así como el de otras revistas hispanoamericanas, excedería los límites de este trabajo, pero deseamos anotar la importancia de estas publicaciones para completar el panorama ultraísta, dada la simultaneidad y relación entre el ultraísmo español y el argentino.

MANIFIESTOS

Hasta el ultraísmo, casi no existió en España la costumbre de publicar "manifiestos literarios", hojas volantes en las que los escritores exponen sus credos estéticos y sus lemas de combate.

Cansinos-Asséns nos hace una pequeña historia de los manifiestos literarios en España: "Los modernistas no llegaron a lanzar ninguno; sus nombres sólo ilustraron un documento bélico: la protesta contra el manifiesto de Echegaray. Gómez de la Serna lanzó en 1910 "Mis siete palabras" y otras "encíclicas" forjadas en las prensas de la Cripta de Pombo. Le siguieron Goy de Silva, en 1917 - proclamando un neo-lirismo semejante al de Phileas Lebesgue en Francia-, y en $1918 \mathrm{Vi-}$ cente Huidobro,-con su promulgación del creacionismo" ${ }^{67}$.

66 "Contemporary Spanish Poetry", en The Texas Quarterly, Spring, 1961, página 6r.

67 Cf. Cansinos-Asséns, Rafael, "Vertical. Manifiesto ultraísta", en Cervantes, dic. 1920, págs. 115-116. 
Ya hemos hablado del primer manifiesto ultraísta, el que se redactó a raíz de la entrevista entre X. Bóveda y CansinosAsséns, publicado a fines de 1918. Es importante, no por su contenido doctrinario, que falta en absoluto, sino porque expresa el anhelo indeterminado de renovación literaria -eje del ultraísmo- y porque es la primera manifestación colectiva y punto de partida del movimiento.

$\mathrm{Al}$ reccrrer las páginas de las revistas ultraístas encontramos muchos artículos, declaraciones e incluso poemas que pueden ser considerados como manifiestos ${ }^{68}$. Pero "manifiestos" propiamente dichos encontramos —además del citado- solamente otros dos, uno breve, firmado por Isaac del Vando-Villar y aparecido en Grecia el 30 de junio de I9.19. Dice así:

\section{MANIFIESTO ULTRAISTA}

Platónicamente estamos exponiendo nuestra moderna doctrina ultraista en las columnas de Grecia sin querer molestar a los fracasados maestros del novecientos.

Hemos procedido de esta forma por entender que el olvido y el silencio serían las armas más certeras para herirles en sus rancios credos estéticos.

Pero he aqui que ellos acogen nuestra moderna lírica irónicamente, haciendo creer a los que con inquietud nos miran, que somos alienados y quieren de esta suerte llevarnos al manicomio del olvido.

Porque ellos son unos plagiadores conscientes $\mathrm{e}$ inconscientes de nuestros clásicos y ninguna cosa nueva nos han

68 Cf. p. e. el poema "Scherzo ultraísta" de Romero y Martínez, en el capíulo sobre las revistas (Grecia). También incluimos algunos de los aludidos ariculos sobre el arte nuevo en el apéndice de documentos. 
revelado ni podrán revelárnosla. Y nosotros estamos limpios de ese pecado y tenemos imágenes e ideas modernas para hacer florecer de entre sus palimpsestos nuevas flores cuyos perfumes, por lo exóticos, deleitarán a los más sutiles ingenios que sienten la avidez del futurismo artístico.

Nosotros podremos estar equivocados, pero nunca podrá negársenos que nuestra manera de ser obedece al mandato imperativo del nuevo mundo que se está plasmando y hacia el cual creemos orientarnos con nuestro arte ultraísta.

Triunfaremos porque somos jóvenes y fuertes, y representamos la aspiración evolutiva del más allá.

Ante los eunucos novecentistas desnudamos la Belleza apocalíptica del Ultra, seguros de que ellos no podrán romper jamás el himen del Futuro.

ISAAC DEL VANDO-VILLAR ${ }^{69}$.

El otro, y único que pretende trazar un programa doctrinario, es el "Manifiesto Vertical" de Guillermo de Torre.

Apareció como suplemento en el número cincuenta de Grecia, del $\mathrm{I}^{\circ}$ de noviembre de 1920. (Véase aq̣uí el grabado $\mathrm{n} .^{\circ} 2$. ) Guillermo de Torre fue el teórico entusiasta del movimiento. Conocía con amplitud y profundidad la marcha y contenido dé los hermanos movimientos europeos de vanguardia. Estaba pues en condiciones para definir el ultraísmo y tratar de darle un contenido teórico. Llama a su manifiesto "Vertical" y dispone las letras del título verticalmente, en forma de surtidor o de plomada, con la tipografía expresiva cara a los ultraistas. Cansinos-Asséns busca justificativos al título de este manifiesto :

69 En Grecia, núm. 20, 30 de junio de 1919, pág. 9. 
La palabra Vertical evoca también en nosotros la idea del surtidor, que es la plomada inestable, la plomada dinámica y rebelde, que no se resigna a sostener el dorso de la estatua antigua como ese travesaño oculto en el interior de ciertas esculturas, sino que se afana por alcanzar un límite más alto, por prolongarse en el sentido opuesto al que le marca la fatalidad de la ley de gravitación, por no ser fatidica en suma; y de ahi su sollozo y su vulnerabilidad; pero de ahí también su suprema victoria de cambiar la plomada en airón, venciendo, aunque sólo sea intencionalmente, las fatalidades físicas. Además...

Nunca como ahora la actitud vertical se impone y justifica, pues, en realidad, la aspiración de los surtidores y de las cimeras románticas ha sido lograda en nuestros días, ya que los hombres que realmente volaron en los horizontes han alargado y realzado la figura humana, elevándola a donde no lo lograron los antiguos coturnos trágicos. En realidad, la frente del hombre moderno, actual o futuro volador, toca en las nubęs, y es él -y así habrá de concebirse en lo futuro al Mercurio de los pies aligeros- como un gigante enhiesto y vertical que camina llenando el espacio entre la tierra y el cielo en toda su materialidad y representando en cada instante el eje sobre que gira el universo. (Retorno al antropocentismo clásico.) La palabra Vertical puede ser por lo tanto lema de un lábaro de arte moderno.

Por lo demás, Guillermo de Torre exalta y glosa el simbolismo de esta palabra, en adelante su verbo fatídico, en inspirados ditirambos, que recuerdan por su ingenuidad efusiva los gritos reiterados y matinales de los nautas ante la tierra nueva. Vertical ha de ser la intención de su arte, y él nos explica esta intención primordial desdoblándola en otras, somo si abriese ante nosotros series de conchas, todas agraiadas con la misma perla. A veces adopta un aire grave y

aL ULTRAISMO. - 5 
algo impertinente de profesor, e imita con gran fortuna las más arduas y remotas abstracciones mallarmeanas. Pero en ciertos momentos logra desenrollar a nuestra vista panoramas ideológicos, que por el apresuramiento con que desfilan las palabras y el aire de folletin actuado que asumen los conceptos, recuerdan las cintas cinematográficas de gran metraje, con tal eficacia, que hasta nos parece oir el ruido que hace - de música para sordos- la manivela del operador, refleja y archiva cuanto desfila ante su objetivo ${ }^{70}$.

El manifiesto está redactado en el estilo peculiar del Guillermo de Torre ultraísta, pleno de neologismos y cultismos que lo hacen casi ininteligible. Llama al ultraísmo:

"Dehiscencia del verticilo heptacromista". "Meridio plenisolar". "Viajes en la planitud pura del espacio isótropo", etc.

Es en realidad, este manifiesto, un resumen de las tendencias artísticas, desde el futurismo al dadaísmo."

No es ésta la única ocasión en que Guillermo de Torre expuso las intenciones del ultraísmo. Sus definiciones, teorizaciones y exhortaciones están dispersas en las revistas ultraístas y recopiladas, en gran parte, en Literaturas europeas de vanguardia.

Transcribimos algunas de las que, con el título: "Diagra-. ma Mental", aparecieron en Ultra (núm. I8, Io de noviembre de I92.r).

¡Hay que multiplicarse en los horizontes vitales!

Los motores suenan mejor que endecasílabos.

Optimismo - jovialidad- luminoso occidental.

70 Cansinos-Asséns, Rafael, "Vertical. Manifiesto ultraísta", en Cervantes, dic. 1920, págs. II7 a II9. - Mucho menos benévolo es el comentario que de este manifiesto hace E. Díez-Canedo en España, núm. 292, año VI, Madrid, I920, pág. II. 
Derribemos las columnas turriebúrneas, al aterrizar sobre la planitud nunista de hoy.

- Bellas estilizaciones caricaturales.

¡Oh! maravillas, un instante aprehensibles, de la fugacidad.

Y nuestras carcajadas rompen el énfasis de lo anacrónico.

Las imágenes polipétalas se despliegan velivolantes y se desdoblan en perspectivas metafóricas.

Ha desaparecido el sentimentalismo estrangulador.

Al leit-motiv erótico ha sustituido la sugestión energética.

Rechazando la morfina, me inyecto tres episodios de film norteamericano.

En el dintorno de las planitudes pictóricas, los volúmenes se entrechocaron en compenetraciones futuristas. Cubicaciones geométricas: la realidad intelectual por encima de la apariencia sensorial.

Las figuras distienden sus líneas elásticas, y hay armónicas asunciones del color-forma noviestructural en los cuadros de Delaunay.

Perspectivas sintéticas de las palabras en libertad.

Jorge Luis Borges, en su artículo "Ultraísmo", publicado en Nosotros (Buenos Aires, 1921), enunció los principios del movimiento. 
En la revista mural Prisma, de Buenos Aires, apareció, a fines de 1921, una "Proclama" ultraísta, que fue reproducida en Ultra (núm. 21, I de enero de 1922), firmada por Borges, Guillermo Juan, Eduardo González Lanuza y Guillermo de Torre (cf. Apéndice de documentos).

A mitad de camino entre el manifiesto y el "gesto" irreverente se encuentran las frases provocativas - generalmente anónimas - con que se define o hace referencia al ultraísmo. Estas boutades, como las llama Guillermo de Torre, aparecieron casi todas como frases sueltas en Ultra. Veamos algunas:

Recomendamos a los hombres pesados la lectura de nues. tras páginas matinales.

(Ultra, núm. 9. 30 abril, 1921)

El ultraismo consiste en volver e! mundo del revés, y en rasgar la originalidad del envés inmáculo.

(Ultra, núm. 9, 20 abril, 1921)

Los ultraístas, que rehuimos las promiscuaciones de catálogos, sólo otorgamos nuestra amistad, entre la fauna circundante, a los humoristas e individualistas.

(Ultra, núm. 12, 30 mayo, 1921)

Desorientar al público y despistar a los profesionales retardarios es, a más de una venganza lícita, motivo para que los ultraístas se encuentren a sí mismos.

(Ultra, núm. 12, 30 mayo, 1921)

Los poemas ultraístas se confeccionan arrojando las palabras al azar sobre la plenitud cósmican

(Ultra, núm. 12, 30 mayo, 1921)

Los verdaderos adictos a nuestra tendencia amanecen un día ultraístas y se duermen al siguiente antiultraístas.

(Ultra, núm. 12, 30 mayo, 1921) 
Propugnamos una antiliteratura implacable, devastadora de todas las topificàciones arraigadas, ya hemos afirmado que "Ia literatura no existe: el ultraísmo la ha matado". De ahi el título de nuestra próxima encuesta, dirigida a los jóvenes. y viejos profesionales: "¿Por qué escribe usted aún?"

$$
\text { (Ultra, núm. 9, } 30 \text { abril, 1921) }
$$

¿Qué es el ultraísmo?... El ultraísmo es el abecedario de los poetas analfabetos.

(Ultra, núm. 3, 20 febrero, 1921)

ULTRA el mejor insecticida.

(Ultra, núm. 3, 20 febrero, 1921)

El ultraísmo es la capital de la literatura española. Muchos poetas provincianos se han perdido en su Puerta del Sol.

(Ultra, núm. 3, 20 febrero, 1921)

Los poemas ultraistas son los arcos voltáicos que alumbran la noche de las calles.

(Ultra, núm. 7, 10 abril, 1921)

Asomarse a las páginas de Ultra es asomarse a los balcones del infinito.

(Ultra, núm. 7, 10 abril, 1921)

Crear, crear y crear. El arte nuevo sólo ha de tener frente, no ha de tener espalda.

(Ultra, núm. 13, 10 junio, 1921)

¿Quiénes están con nosotros? Los fuertes, los puros, los selectos.

¿Quiénes están contra nosotros? Los impotentes, los contaminados y los tullidos.

(Ultra, núm. 13, 10 junio, 1921) 
La palabra libre. El pensamiento sin bridas. Una forma fecunda suelta y desbordante. Todo eso y mucho más es el ultraísmo.

(Ultra, núm. 13, 10 junio, 1921)

Después del ultraísmo, el fin del mundo.

$$
\text { (Ultra, núm. 8, } 20 \text { abril, I92r) }
$$

Los ultraístas hemos descubierto la cuadratura del círculo. (Ultra, núm. 7, 10 abril, 1921)

El ultraísmo es la rana que crió pelos.

(Ultra, núm. 2, 1o febrero, 1921)

Ultra puede aplicarse como un motor a todos los ismos rezagados.

(Ultra, núm. 9, 30 abril, 1921)

Ultraísmo: único oxígeno vital.

(Ultra, núm. 7, 30 abril, 1921)

Anuncio: gran stock primaveral de géneros ultraístas. Novedades sin competencia, garantizamos la alta calidad de nuestros géneros.

(Ultra, núm. 10, 10 mayo, 1921)

El ultraísmo es el verso que se recita sin mover la lengua. La canción que se canta a un niño dormido sin despertarlo.

(Ultra, núm. 2, 1o febrero, 1921)

El ultraísmo es algo atmosférico que gravita ozonizante sobre los medios impuros al nivel de los aviones y de los cerebros icarianos.

(Ultra, núm. 1o, 10 mayo, 1921) 
VELADAS Y REUNIONES ULTRAÍSTAS

IPalabras incendiarias !

IMuecas burlescas!

¡Intenciones nihilistas!

¡ Gestos rebeliosos! 71

Para hacer una historia del ultraísmo debemos considerar, por una parte, su producción poética o muchas veces seudo-poética, dispersa casi toda en las revistas. Por otra, su aparato exterior, sus manifiestos más o menos ruidosos, sus veladas tumultuosas, los desplantes revolucionarios e iconoclastas de sus miembros. Pequeña crónica, tal vez, "petite histoire" de pequeños hechos. Pero éstos tienen su razón y su sentido como exteriorización vital de una actitud frente al mundo y la literatura.

Hemos hablado ya de las tertulias en el "Colonial". Éstas eran las reuniones habituales. Se realizaron además otras extraordinarias, tumultuosas, que despertaron la reacción del público y la prensa.

Los ultraístas se enfrentaron con el público por primera vez el 2 de mayo de 1919, en el Ateneo sevillano, en una velada organizada por el grupo de colaboradores de Grecia.

Transcribimos la crónica de esta fiesta, escrita por Adrianvs, suponemos que se trata de Adriano del Valle ${ }^{72}$.

\section{LA FIESTA DEL ULTRA}

Organizada por los elementos literarios que integran esta redacción, y bajo la égida espiritual de Rafael Cansinos-As-

71 Del "Manifiesto Vertical" de Guillermo de Torre.

72 Grecia, núm. XV, 19ı9, págs. 19 y 20. 
séns, se celebró en la noche del 2 del corriente, en el salón de actos del Ateneo sevillano, una interesantísima velada acer. ca de la nueva lírica del Ultra, fiesta en la que tomaron parte. a más de la redacción de Grecia, los distinguidos escritores Pedro Luis de Gálvez, Juan G. Olmedilla y Pedro Garfias.

Esta velada, primera que se celebra en España orientada hacia las nuevas tendencias poéticas, resultó de suma brillantez gracias al valiosísimo prestigio que, para su mayor éxito, aportara el gran Condestable del Ultra, Rafael Cansinos-Asséns, con el envio de algunos de sus bellisimos poemas.

El acto comenzó con la lectura de unas originales cuartillas de Pedro Luis de Gálvez, que fueron aplaudidísimas, acerca de las nuevas normas literarias.

El joven y admirable poeta Pedro Garfias, uno de los más fervorosos discípulos de Rafael Cansinos-Asséns, recitó magistralmente un bello poema del precursor del Ultra, Guillermo Apollinaire; otro, no menos bello, de Cansinos-Asséns, el admirable alfarero de juventudes; unas poesías de Adriano del Valle, $y$, finalmente, unos poemas del propio Garfias, enormemente líricos y emotivos, que fueron calurosamente elogiados.

A continuación, nuestro querido compañero de redacción, el culto literato Miguel Romero Martínez, leyó de una manera fervorosa su fidelísima versión literal de la "Canción del automóvil", de Marinetti: el inspirado y original poema ultraísta de Pedro Raida titulado "Confesión": una de las más modernas y sinceras composiciones de la nueva escuela: la "Canción del aeroplano", del gran poeta José María Romero, el apolonida mediterráneo más dilecto de las Musas; "El poema de las calles trịnfales", de nuestro director Isaac del Vando-Villar, bella composición que marca una evolución particularisima en los módulos literarios de su autor, y por último leyó también Miguel Romero su "Scherzo ultraista, 
Op. II", original y vigoroso poema de juventud, mezcla de alto lirismo y humorismo nihilista, que canta las excelencias del bolchevismo literario contra los escritores mediocres que no quieren incorporarse a las nuevas corrientes poéticas del siglo.

Juan González-Olmedilla, otro de los jóvenes poetas que recientemente han profesado en los nuevos ritos líricos del Ultra, leyó a continuación unas ingeniosas cuartillas que fueron premiadas con aplausos calurosos.

Cerró el ciclo lírico Pedro Garfias con unas emocionadas palabras de salutación al Apóstol del Ultra y a los discípulos ausentes, que fueron coronadas por una nutrida salva de aplausos.

El acto terminó dentro del mayor entusiasmo.

Para dar una idea del tono en que debió de transcurrir esta primera reunión ultraísta, reproducimos algunas de las composiciones que alli se leyeron.

Veamos un fragmento de la "Alocución a los hermanos del Ultra" de Pedro Garfias :

Alcemos nuestra frente a las estrellas.

Abramos nuestros ojos a la vida

que ha de darnos la imagen nueva...

Tendámoslos al ultra de las colinas frescas,

al más allá

sin horizontes ni fronteras.

O esta "Canción del aeroplano", de José María Romero, de temática futurista.

ITu corazón de mil caballos!

Abandona la tierra y dirigete al cielo, oh mi águila blanca, de alas enormes y vibrantes; 
mueve tu hélice potente,

$y$, entre torbellinos de aire,

elévate en el espacio

y sigue tu ruta hacia el azul.

Sube en la tempestad,

nauta del Infinito:

pasa serenamente sobre el trueno del mar,

apaga sus bramidos con tu motor rugiente;

elévate entre los torbellinos del viento;

corta con tu timón.

el vientre de las trombas

$y$ opón al furor del huracán

tu corazón de mil caballos.

${ }^{73}$.

Pedro Garfias comenta en Cervantes esta fiesta y nos habla de "las admiraciones confusas" y de las "hipócritas sonrisas" que suscitaron estos jóvenes que por primera vez ofrendaron "en el altar del Ultra, ante los filisteos, de frente lisa y ojos turbios" 74 .

Han sido los amigos de Grecia: Isaac hermano mío en fervor y en amor al Maestro; Adriano, puro y sentimental; Miguel, fuerte y optimista... han sido los amigos de Grecia, fervorosos y nobles $y$ entusiastas, quienes han ofrendado primeramente en el altar del Ultra, ante los filisteos, de frente lisa y ojos turbios. Han sido ellos, quienes han ofrendado

73 Grecia, núm. 14, 30 abril 1919, págs. 10 y 11 .

74 Apareció en Cervantes y fue transcrito en Grecia, núm. XXX, págs. 9 y 10, 1919.

Incluimos además los discursos de Juan González-Olmedilla y de Pedro Luis de Gálvez en el apéndice de documentos. Otra composición: "Scherzo ultraísta" de Miguel Romero, ya ha sido incluida en otro capítulo. 
primero, alegremente, clara la voz y el corazón. Y por eso, oh afines, vosotros que os ahogáis de vuestra propia emoción, y sentís desbordarse por vuestro pecho la ansiedad, vosotros, que tembláis ante el ara aún impoluta, debierais deshojar, sobre vuestras nostalgias de desterrados que miran al cielo, todas vuestras flores de júbilo.

Yo os traigo de allá, en el nido escondido de mi corazón; algo como un aroma en mi boca, como un hosanna vibrante aún en mis oídos.

Porque yo he visto a esa fiesta, y he actuado en ella con una pobre ofrenda de fervor, y puedo deciros cómo ardió el fuego sagrado, alimentado constantemente por manos solicitas, y cómo se mantuvieron claras las antorchas sobre vuestras cabezas.

$\mathrm{Y}$ puedo hablaros del asombro de algunos, para quienes nuestras palabras eran como velos que les descubriesen horizontes insospechados, en la belleza intacta de las nuevas rimas, y de la cómica indignación de otros, ante las voces frescas, que venían a turbar el silencio de su vacio interior.

iOh, las admiraciones confusas y las hipócritas sonrisas! $Y$ he de contaros cómo se alborotaba de gozo mi corazón, contemplándolo todo. Porque todo ello cantaba a coro nuestro triunfo.

Porque esta fiesta del Ultra, en el Ateneo sevillano, ante la admiración de los sorprendidos y el asombro de los filisteos, tiene toda la solemnidad de una primera fe de vida, de un primer acto de presencia, impetuoso y entusiasta, que ha de alentarnos a nuevos combates.

Hemos celebrado nuestra fiesta del Ultra, y han sido los hermanos de Grecia quienes se han sacrificado primeramente ante el ara. 
Hemos celebrado nuestra primera fiesta del Ultra, unidos todos en una misma unción fervorosa y un entusiasmo gemelo. $\mathrm{Y}$ nuestros encendidos hosannas, lanzados a los coros de los filisteos en una exaltación de júbilo, volaron hacia vosotros, oh afines, como palomas anunciadoras de albas, y hacia la sombra amada del Maestro, que presidía la fiesta con un rayo de sol en los ojos.

Pedro Garfias

El 2 de marzo de 1920 Pedro Garfias decidió ir, esta vez solo, al sacrificio y leyó sus poesías en el Ateneo sevillano. Fue presentado por Adriano del Valle. Terminado este acto fueron los ultraístas a "festejar el nuevo éxito de incomprensión" que obtuvo Garfias. En un artículo aparecido en Grecia, González Olmedilla nos hace el relato de esa "primera gesta de la epopeya ultraísta". Garfias, Adriano del Valle, Vando-Villar y Olmedilla, poseídos de "vértigo iconoclasta", a semejanza de los futuristas y otros "istas", salieron por las calles de Sevilla a destruir el pasado a golpes de patatas y panecillos duros. (CF. el apéndice de documentos.)

Pero las más famosas reuniones ultraístas, las que alcanzaron mayor repercusión, fueron las celebradas en Madrid en 1921. Estas representaciones de los ultraístas como grupo desafiante constituyen lo más pintoresco de la "pequeña crónica" del movimiento.

Guillermo de Torre, sin aludir a la fiesta del Ateneo sevillano anteriormente comentada, que no fue, por lo visto, demasiado agitada, nos da la siguiente justificación de las otras dos ruidosas veladas, de los "gestos y ademanes" ultraístas 75 . Nos dice:

75 Así se titula el capitulo de Literaturas europeas de vanguardia en el que se refiere a estas reuniones. 
El movimiento ultraista, aspirando a justificar verdaderamente este título dinámico, en el deseo de simultanear, al igual que las tendencias oficiales y radicales extranjeras, la obra literaria pura con el gesto accional y el ademán combativo, incluso dando parte a la polémica espontánea y humoristica, inició a comienzos de 1921 su actuación exterior... ${ }^{76}$.

Hay pues, en la intención de estas veladas, una indudable influencia del futurismo y dadaísmo como lo reconoce Guillermo de Torre al decir "al igual que las tendencias afines y radicales extranjeras..." Recordemos, en efecto, las hazañas de los futuristas por todas las ciudades italianas, afrontando la iracundia del público; recordemos que Marinetti y sus compañeros conocieron "la voluptuosidad de ser silbados", según sus palabras. También DADÁ, y en mayor grado, si cabe, hizo cstentación de "gestos" excéntricos, recurrió a los medios de acción más ruidosos, buscó con delectación el ridículo y el absurdo. Futuristas y dadaístas afirmaron que el arte no es una cosa seria. DADÁ buscaba la burla, la caricatura, el nihilismo. Las características de DADÁ se encuentran más en sus "gestos" que en sus obras. Recordemos la primera soirée dadaísta en el Salón de Independientes de París (el 5 de febrero de 1920) en la cual los jóvenes "dadás" se encaraban con el público y le preguntaban: - "No comprendéis lo que hacemos, ¿verdad? Pues bien, queridos amigos, nosotros lo comprendemos menos todavia" 77.

También los ultraístas españoles buscaban, en alguna medida, asombrar al -público, épater les bourgeois. Pero, sospechamos, para el innato sentido de la dignidad que hay en todo español (aunque sea muy joven y además ultraísta), este "buscar" el ridículo, o por lo menos "afrontarlo" tiene que haber

76 Literaturas.... pág. 56.

77 Cf. Torre. GuIllermo DE, Literaturas..., pág. 188. . 
sido un paso difícil. De ahí aquella expresión de Pedro Garfias, de "ofrendar en el altar del Ultra", de ahí también el tono desilusionado con que Guillermo de Torre comenta, como veremos, la segunda $-\mathrm{y}$ última - de las veladas celebradas en Madrid.

Veamos lo ocurrido en la primera de ellas. Para cumplir estos propósitos enunciados por Guillermo de Torre: "simultanear... la obra literaria pura con el gesto accional y el ademán combativo...", los ultraístas prepararon una velada en $\mathrm{Pa}$ risiana.

En el número uno de Ultra encontramos el anuncio de esta primera reunión. Se anuncia, además de la lectura de poemas, una parte dedicada a la música y otra a las artes plásticas: Juan del Brezo leería unas cuartillas sobre música modernísima y Rafael Galindo ejecutaría poemas sinfónicos nacionales y extranjeros. El local estaría decorado por los esposos Delaunay y expondrían los modernos pintores Vázquez Díaz, Wladyslaw Jahl y Marjan Paskiewicz. Este último daría una conferencia sobre pintura modernísima ${ }^{78}$. No sabemos si todos los puntos programados llegaron a cumplirse, dado lo accidentado de la velada. Los jóvenes pidieron a Mauricio Bacarisse, que aunque no era ultraísta tenía hacia el movimiento una actitud de amistad y comprensión, que hiciera la presentación y el resumen de la reunión.

Hemos encontrado en el periódico $\mathrm{La}$ Voz la crónica de esta vèlada que se realizó el 28 de enero de 1921 y la transcribimos pues, aunque su autor sea "del otro bando" $y$ por momentos excesivamente burlón e irrespetuoso, tiene el valor de un testimonio vivo:

78 Cf. Ultra, núm. 1, 27 enero 1921. 


\section{DEL MADRID FUNAMBULESCO}

\section{En plena apoteosis del disparate}

Los "ultraistas" dieron anoche una función de gala

Entre el elemento joven de las peñas literarias madrileñas despertó gran interés el anuncio de una sesión extraordinaria y solemne, que los llamados poetas "ultraístas" se disponían a celebrar en el salón de espectáculos de Parisiana. Por otra parte, el lugar donde debía verificarse el acto, rodeado habitualmente de una temperatura neurótica y decadente, propicia a todo género de curiosidades medulares, era clima cordial para todo género de extravagancias espirituales, y la salita de Parisiana se llenó de un público mitad intelectual y mitad morbosamente galante.

Al filo de la una comenzó la sesión. Antes se habian cubierto los cuatro espejos de la sala con otros tantos carteles encabezados por dibujos desconcertantemente "ultraistas". Un pelícano, una figura "ultra", un caballo con alas y una... mesa revuelta.

Silencio profundo. Hay mucha luz. Cierto frío en las médulas.

\section{Comienza el acto}

Humberto Rivas, joven bastante conocido ya en las letras. se adelanta con unos pliegos en la diestra. Expectación.

Lee unos pensamientos de Rafael Cansinos-Asséns, y una "especie de preceptiva de la estética, de "su estética" en la generación de la poesía ultraista. Dice que el "ultraísmo" es el más allá de la concepción y de la expresión poética, para lo cual la imagen debe ser el eje de simbolización externa. El público aplaude respetuoso, pero en cuanto el Sr. Rivas comenzó a recitar un poema comenzaron los murmullos, hasta llegar a la franca interrupción. 
Hubo paréntesis de calma, en los cuales pudo apreciarse uno que otro concepto del poeta. Que Fra Angélico, Góngora, Mallarmé y Rubén Dario (¿Y Julio Herrera Reisigs?) (Sic) son los precursores de este movimiento literario, cuyo curso debe enfrentar solamente el porvenir sin mirar el pasado...

Le sigue en el uso de la palabra el joven de Diego, catedrático del Instituto de Soria, y cuando éste dice "un remo, dos remos, tres remos..." y "al despertar volaron todos los pájaros". las risas de la concurrencia tomaron proporciones escandalosas.

Rafael Lasso de la Vega se aproximó entonces a las bambalinas con su poema en la mano. Al pretender dar lectura de una composición en francés - nadie se explicaba por qué un poeta español escribe sus versos en una lengua extranjera-, el escándalo se hizo dueño de la situación.

- Q Que hable en castellano!... I No hay derecho!... ¡Además, no se le entiende!

Hablan luego los jóvenes César Comet, Guillermo de Torre, y las risas y chirigotas en alta voz continuaron.

\section{Un Poeta a la Clásica Usanza}

En esto hizo su aparición un joven de contextura débil en apariencia. Sus primeras palabras lograron el milagro de calmar los ánimos, y a poco de comenzar el recitado de una composición, las risas se tornaron en aplausos atronadores. El público, animado de buena $\mathrm{fe} y$ de un profundo afán comprensivo, estaba ansioso por escuchar algo que le interesase, y rompió en una salva de aplausos cuando el Sr. LópezParra, que así se llama el que ocupaba el turno, terminó la lectura de una composición concebida, expuesta y tratada según la clásica técnica poética, no obstante la forma personalísima de su factura. 
-Eso es poesía clásica castellana... El Sr. López-Parra hacía gestos de protesta, pero un amigo le gritó:

- T Te has colado de matute!

\section{El Antipapa o el Caballero Pernil}

Pero quien sí se escurrió de matute fue un simpático mozo andaluz, correcto de maneras y de rostro suavemente cínico. Con gran desenfado le dirigió al auditorio una composición originalísima, en que se habla de "ir a la tasca de Cronos, beber el aguardiente de Dios y... hacer temblar a las es. feras".

El público, que alcanzaba entonces las más altas temperaturas, tributó al Sr. Pernil (así se llama el nuevo poeta) una ovación cerrada; pero ante el asombro de todos se adelantó uno de los poetas más caracterizados del cenáculo y dijo:

-Estos aplausos no van a la cuenta del ultraísmo.

$\mathrm{Y}$ ardió Troya.

¿Qué había pasado? Sencillamente, que el Sr. Pernil se había "colado de matute" y leído su composición que "no era ni ultraísta ni nada". El señor Pernil se vio obligado a salir del escenario. Al reincoporarse al público, éste le rodeó cariñosamente, $y$, obligándole a subirse a una silla, le hizo hablar a los gritos de: ¡Viva el antipapa! |Viva el ultraísta máximo!

Pernil dijo, poco más o menos:

-Yo vine a Parisiana a divertirme; pero al saber que esta nooche se celebraría una sesión ultraísta, me presenté a esos señores (señalando a los auténticos), les mostré mi composición, la leyeron, les gustó y me permitieron leerla. Si ahora se arrepienten, mia no es la culpa.

A todo esto, los señores Bacarisse, Ciria Escalante, González-Olmedilla, Lasso de la Vega, Comet y Panedas, sobre el escenario, hacían grandes esfuerzos por hacerse oir. Vano empeño. La gritería había llegado a su colmo, y, lo que era peor,

EL ULTRAÍSMO. -6 
el público perdió la fe en la seriedad del acto, toda vez que había podido pasar por "ultraísta" de verdad un poeta que no era más que... un bromista andaluz.

\section{El "Duetto" Rello}

Al presentarse los hermanos Rello, dos jovencitos enlutados, y espléndidos ejemplares biológicos, dijo alguien:

- Pero esto es un número de circo.

El más pequeño leyó unas cuartillas sobre "su estética". Leía muy de prisa y un "tic" feroz le hacía parpadear multimillonariamente. Su hermano leyó varios poemas, que apenas si se oían, pues un grupo de espectadores, entre los que se destacaban Juan José Llovet, Joaquín Dicenta (hijo) y Xavier Bóveda, había estrangulado de hecho la reunión. Gracias a un intermedio musical y a la escasa concurrencia en la parte última del programa, se pudo oir al Sr. Bacarisse, que presidía el acto. Con palabra fácil y acento conmovido, hizo un resumen de la velada, lamentándose de la incomprensión de ciertas gentes incapacitadas para toda navegación de altura espiritual ${ }^{79}$.

Veamos, para contrabalancear, la versión que dieron los ultraístas del desarrollo de esta velada :

79 M. A. BedoYA, en La Voz, Madrid, 29 enero 1921, pág. 2. Observemos que en esta época, $X$. Bóveda había renegado del ultraismo y militaba con sus contrarios.

El artículo de Bedoya terminaba con algunas consideraciones sobre los orígenes del ultraísmo, bajo el epígrafe: "Unas cuantas apostillas en serio". Como réplica a este artículo, encontramos en el núm. 2 de Ultra (ro de febrero de 1921) este "suelto": "Hemos abierto una suscripción para comprarle unos anteojos al Sr. Bedoya". También Mauricio Bacarisse replicó en un artículo llamado "Otra vez Hertera y Reissig", (España, núm. 301, 1921, págs. I I y 12) que incluimos en el apéndice de documentos. 


\section{NUESTRA VELADA}

A pesar de las intrigas de los que se confabularon para malograr nuestros propósitos, la velada de Parisiana colmó nuestras más fervientes aspiraciones. La calidad y el número de las personas que acudieron a oirnos, hubieran sido suficiente garantía de nuestro triunfo. Pero hubo más, algo que nos enorgulleció más todavía: Las protestas y la rabia impotente de unos cuantos fracasados, al frente de los cuales se destacaban Joaquín Dicenta y Juan José Llovet, sepultados más que por nosotros, por su propia obra.

Hemos conseguido todo lo que nos proponíamos. Nuestra velada despertó enorme expectación en todas partes. Hacía tiempo que no se discutía un tema literario con tanto interés, $\tan$ apasionadamente. Aunque sólo fuera por eso, estariamos satisfechos. Se nos niega, se nos combate, pero se nos discute y nosotros somos y seremos el motivo de todas las conversaciones, porque estamos resueltos a no dejar en paz a los sordos y a los ciegos.

Desde Humberto Rivas, que habló en nombre de todos, hasta Mauricio Bacarisse, que hizo el resumen de la velada, nuestros compañeros $y$ amigos estuvieron a la altura del noble apostolado que defendemos. J. Rivas Panedas, Jorge Luis Borges, Pedro Garfias, Eugenio Montes, César A. Comet, Gerardo Diego, Lasso de la Vega, Tomás Luque, López-Parra, Ciria Escalante y los hermanos Rello, leyeron hermosos poemas que tuvieron la virtud incomparable de indignar a los cretinos que nos hacen el honor de no comprendernos. Nue:tro movimiento es superior a la mentalidad de hoy $y$ esa incomprensión es nuestro mayor orgullo ${ }^{80}$. 
Guillermo de Torre nos comenta también esta reunión, dice que "revistió los deseados caracteres de agitación, en una atmósfera espiritual huracanada" y nos habla del público, mitad hostil, mitad burlesco y de la encrespada reacción de la prensa madrileña ${ }^{81}$.

El revuelo que suscitó la velada del Parisiana no quitó ảnimos a los ultraístas para realizar una segunda reunión en el Ateneo de Madrid.

Ésta fue anunciada a los cuatro vientos - nos dice Manuel de la Peña- por los carteles de Jahl, que "lanzaban su grito estridente de noticia moderna desde las vías más céntricas" ${ }^{82}$. Estos carteles que tapizaban la Carrera de San Jerónimo invitaban a la reunión del 30 de abril de 1921 . Los participantes del acto nos dan noticias, en la revista Ultra, de lo ocurrido en esta velada :

El Ateneo nos abrió sus puertas deseoso de oir nuestra palabra, nueva y vibrante. La Sección de Literatura quiso que fuésemos a leer nuestros poemas en la tradicional cátedra ateneísta, y nosotros fuimos a ella con la libertad y el entusiasmo, que son dos de nuestras virtudes. Se leyeron cuartillas sobre estética ultraísta, se pronunciaron palabras bautismales y se recitaron poemas, siguiendo este orden: $10^{\circ}$ "Ultraísmo: alegría de ser poeta" y "Caminos de hierro" (poema que publicamos en este mismo número), por Rafael Lasso de la Vega. 2.0 "Consideraciones estéticas" y "Puzzle", poemas por Guillermo de Torre. 3. Palabras de A. M. Cubero. 4. "Exaltación de la Rana ultraica" y "Poema", por López Parra. 5. "Ki-ki-ri-ki" (que publicamos en este número) y otros dos poemas, por Humberto Rivas. 6." "Poemas", por J. Rivas Panedas. 7. "El poema de las manos", por Pérez Doménech. 8. "El anti-yo", estudio teórico sobre el clownis-

81 Cf. Literaturas..., pág. 56.

82 Cf. El ultraisino en España, en la nota preliminar sin número de página. 
mo, y dibujos en la pizarra, por Barradas. 9. "Especímenes", por César A. Comet. 10. Poemas de Ciria y Escalante. 11. "Poemas", por Luque y E. Puche. 12." "Fuegos artificiales", poema humorístico de Vighi, con quien simpatizamos cordialmente, aunque no figura dentro del movimiento ultraísta. La velada fue un éxito clamoroso para nosotros, a pesar de las protestas de una exigua minoria retardataria y obtusa, que originó la indignación del público en general al grito de "idiotas los que protestan", lanzado valientemente por Andrés González-Blanco, fogoso defensor del arte nuevo ${ }^{83}$.

Aunque en este comentario los ultraístas nos dicen que esta velada fue "un éxito clamoroso" , no confirma esta afirmación. el hecho de que ya no se atrevieran a repetir la experiencia, ni tampoco el examen retrospectivo, un poco melancólico, que de ella hace Guillermo de Torre:

Esta falta absoluta de perspicacia y de lealtad captadora por parte del público - tan desemejante al que, en aquellos dias, disfrutaban los dadás parisinos- comprobóse en la segunda velada que organizamos en el Ateneo de Madrid, a fines de abril del mismo año. La expectación había allmentado, percibíase una maligna curiosidad en la gran masa del público literario que llenaba la sala, las recitaciones sucediéronse en una tensión elevada de ataques y contraataques entre el público y los ultraístas... y sin embargo ambos salieron defraudados del salón. Nuestra sinceridad, ya alejada del parti-pris apologético, nos obliga a reconocerlo. Habíamos comprobado definitivamente que faltaba la atmósfera propi-

83 Ultra, núm. 10, 10 de mayo de 1921.

He aquí un fragmento de "Ki-ki-ri-ki", leido por $H$. Rivas, dedicado a la Real Academia Española: "Ki-ki-ri-ki / ki-ki-ri-ki / ki-ki-ri-ki / La gallina más joven ha puesto un huevo / y el gallo del día / mella la sombra / con los dien-

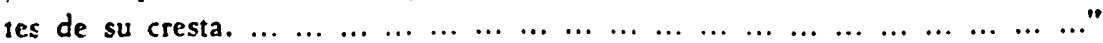


cia, que en el público - prescindiendo, claro es, de ios profesionales literarios reacios o envidiosos- no surgía esa anhelada y mínima élite, indispensable para prestarnos su apoyo cordial. Además, llevando a la extrema sinceridad este análisis de las frustradas gestas ultraístas: Al declarar, inauguralmente, que en nuestro movimiento no existía ningún jefe. que nuestras revistas carecian de directores, y nuestras veladas de presidentes, habíamos formulado una feliz declaración de independencia, sí, pero también quedábamos incapacitados para una acción conjunta y fructífera. La anarquía más absoluta presidía la realización de toda velada $y$. por tanto, sin una fuerza directriz reguladora, no había posibilidad de manifestaciones colectivas ${ }^{84}$.

Así pasó la etapa más agitada del movimiento ultraísta, que dio a estos esforzados jóvenes su momento de mayor popularidad.

REPERCUSIÓN PERIODÍSTICA

El ruidoso ultraísmo atrajo la atención de los críticos y del público. Muchos y divertidos artículos periodísticos suscitó el movimiento, aun antes de su etapa más ruidosa, la de la revista Ultra y las veladas. Manuel Machado en El Liberal (1919), Alberto de Segovia en La Acción (r919), Gómez de la Mata en La Jornada (1919), Hernández Luquero en España Nueva (1919), Gómez Carrillo y otros, dedicaron comentarios al movimiento.

Pero sobre todo la gran ofensiva de 1921 , la realización de la velada en Parisiana y la aparición del primer número de Ultra, cuya llamativa portada cambió la monótona fisonomía de los quioscos madrileños - según comenta Eugenio d'Ors en la ya citada glosa "Ultra tiene razón"-, despertaron un re-

84 Literaturas..., págs. 56 y 57. 
guero de comentarios en los corrillos del Ateneo, en las peñas literarias de los cafés y en la Prensa.

Los críticos periodísticos - nos dice Cansinos-Asséns en $\mathrm{El}$ movimiento $V . P .{ }^{85}$-, se dividieron en tres categorías: los trágicos, los cómicos, y los que adoptaron una actitud intermedia.

Los primeros se indignaban con gestos pontificales por el prurito de novedad y por el lenguaje irreverente que empleaban los revolucionarios. En arte estaba ya todo hecho, los ultraístas eran unos ignorantes que no habían leído La Iliada.

Los críticos de tono cómico sostenían que los ultraístas eran unos jóvenes de buen humor que se habían propuesto divertirse a expensas del público y de los críticos de buena fe. Sus manifestaciones no eran más que un alarde de humorismo. Los comentaristas matizaban sus artículos con disertaciones sobre el humor inglés, francés y español y terminaban felicitando a los jóvenes por la organización de tan formidable bromazo.

A los críticos tragicómicos que alcanzaban el feliz término medio, no les asustaba la modernidad, pero decían que los nuevos poetas no eran verdaderamente modernos, que sus imágenes ya estaban en el Antiguo Testamento. Lo que no podía tolerarse era aquel aire de reto que adoptaban.

Los ultraístas no se limitaron a poner la otra mejilla. Contestaban a veces tratando de refutar los erróneos conceptos de los críticos ${ }^{86}$. En otras ocasiones adoptaban un aire de superior indiferencia :

Pierden lamentablemente el tiempo los cobardes que dirigen anónimos injuriosos a esta Redacción... "Ni más gran.

85 Cf. págs. 88 a 91.

86 Cf. Rivas Panedas, "Nosotros los de Ultra", en Grecia, núm. 25, 1919. págs. 14 y 15 y en Cervantes, julio 1919. págs. 139 a 144. ARroYo, CÉSAR E.. "La Nueva Poesía en América - La evolución de un gran poeta", en Cervantes, agosto 1919. págs. 103 a 106. Ultra, núms, 2 y 3, febrero 192r (anónimos). "Panorama Ultraísta", en Grecia, núm. L, 1920, pág. 16 (anónimo), etc. 
de porque te alaben, ni más vil porque te desprecien; lo que eres, eso eres". Esta frase del místico es nuestro lema ${ }^{87}$.

Pero con más frecuencia se ponían en la línea de combate y contestaban a las pullas con pullas y al desprecio con desprecio :

Ultra premiará con veinticinco pesetas al primero que averigüe lo que tiene en la cabeza el señor Astrana Marín. (Ultra, núm. 2, febrero, 1921).

Al terminar de leer el artículo de Antón del Olmet publicado en el Heraldo de Madrid, tenemos el rostro bañado en lágrimas...

(Ultra, núm. 3, febrero, 1921)

87 En Grecia, núm. 14, 1919, pág. 38. 


\title{
Capítulo III
}

\section{RELACION DEL ULTRAISMO CON OTRAS ESCUE- LAS O MOVIMIENTOS DE VANGUARDIA}

\author{
EL ULTRAÍSMO ESPAÑOL NO ES \\ UNA ESCUELA, SINO UN HAZ DE \\ DIRECCIONES RENOVADORAS.
}

El ultraísmo español no es una escuela 1 . Los intentos de dotarlo de unäestética, de un contenido teórico bien delimitado, son tardíos. Fue, simplemente, un movimiento de superación de la lírica vigente, una reacción contra el modernismo, una voluntad de renovación; un ir "más allá", como lo indica sū nombre. Así lö afirma Cansinos-Asséns :

Este lema ULTRA señala un movimiento literario, no una escuela. Resume una voluntad caudalosa, que rebasa todo límite escolástico. Es una orientación hacia continuas y reiteradas evoluciones, un propósito de perenne juventud literaria, una anticipada aceptación de todo módulo y de toda idea nuevos. Representa el compromiso de ir avanzando siempre con el tiempo ${ }^{2}$.

1 Para definir al ultraísmo argentino, tendríamos que adoptar un enfoque diferente, pues Borges extrajo de la baraúnda del ultraísmo español los rasgos más significativos y los presentó como programa.

2 Cansinos-Asséns, R., "Los Poetas del Ultra", en Cervantes, junio 1919. página 85. 
En otra parte nos habla de "la intención de un ultraísmo indeterminado que aspira a rebasar en cada zona estética el límite $y$ el tono logrados en busca siempre de nuevas formas"... ${ }^{3}$.s

Rivas Panedas también afirma enfáticamente que Ultra no es una escuela:

Ultra, no es rojo, azul, ni amarillo, ni de ningún color del iris; es el tono de luz que ha de alumbrar en adelante, es una fuerza en cada uno que crea un bello acto, pero distinto con respecto a todos. No es nada de nadie, ¡ es alma nuestra, en nuestra alma!

...Ultra es, y será, diga lo que quisiere cada uno decir, tan sólo un ansia de renovación, una potente voluntad de nada definido, enteramente nuestro... Ya se ha dicho mil veces que Ultra no es una escuela; mas dicho está otra vez... el Ultra es invulnerable, porque no es esto ni aquello... ${ }^{4}$.

Podríamos multiplicar los testimonios, pero nos interesa solamente transcribir lo dicho por Guillermo de Torre:

Sólo esta idea elemental de ruptura y avance, sólo este deseo indeterminado y abstracto de iniciar una variación... ya era en principio una solución y un ideal ${ }^{5}$.

Este propósito amplio, indefinido, es el enunciado también en el primer manifiesto ultraísta que hemos transcrito más arriba.

Podemos distinguir en el ultraismo dos vertientes: la de déstrucción de las formas ya infecundas y caducas (dirección ésta estrepitosa y vandálica, común a los movimientos vanguardistas europeos). La otra vertiente, ¿hasta qué punto lograda - fracasada?, la positiva: anhelo de encontrar nuevas formas, nuevos medios de expresión para un espíritu también nuevo.

3 Cansinos-Asséns, R., "Liminar", en Cervantes, enero 1919, pág. 2. 4 "Protesto en nombre de Ultra", en Cervantes, set. 1919, pág. 146. 5 Literaturas..., pág. 46. 
En otra parte nos habla de "la intención de un ultraísmo indeterminado que aspira a rebasar en cada zona estética el límite y el tono logrados en busca siempre de nuevas formas"... ${ }^{3} .34$

Rivas Panedas también afirma enfáticamente que Ultra no es una escuela :

Ultra, no es rojo, azul, ni amarillo, ni de ningún color del iris; es el tono de luz que ha de alumbrar en adelante, es una fuerza en cada uno que crea un bello acto, pero distinto con respecto a todos. No es nada de nadie, ¡ es alma nuestra, en nuestra alma!

...Ultra es, y. será, diga lo que quisiere cada uno decir, tan sólo un ansia de renovación, una potente voluntad de nada definido, enteramente nuestro... Ya se ha dicho mil veces que Ultra no es una escuela; mas dicho está otra vez... el Ultra es invulnerable, porque no es esto ni aquello... ${ }^{4}$.

Podriamos multiplicar los testimonios, pero nos interesa solamente transcribir lo dicho por Guillermo de Torre:

Sólo esta idea elemental de ruptura y avance, sólo este deseo indeterminado y abstracto de iniciar una variación... ya era en principio una solución y un ideal ${ }^{5}$.

Este propósito amplio, indefinido, es el enunciado también en el primer manifiesto ultraísta que hemos transcrito más arriba.

Podemos distinguir en el ultraísmo dos vertientes: la de déstrucción de las formas ya intecundas y caducas (dirección ésta estrepitosa y vandálica, comúñ a los movimientos vanguardistas europeos). La otra vertiente, chasta qué punto lograda - fracasada?, la positiva : anhelo de encontrar nuevas formas, nuevos medios de expresión para un espíritu támbién nuevo.

3 Cansinos-Asséns, R., "Liminar", en Cervantes, enero 1919, pág. 2.

4 "Protesto en nombre de Ultra", en Cervantes, set. 1919, pág. 146.

5 Literaturas..., pág. 46. 
En otra parte nos habla de "la intención de un ultraísmo indeterminado que aspira a rebasar en cada zona estética el límite y el tono logrados en busca siempre de nuevas formas"... ${ }^{3}$. si

Rivas Panedas también afirma enfáticamente que Ultra no es una escuela:

Ultra, no es rojo, azul, ni amarillo, ni de ningún color del iris; es el tono de luz que ha de alumbrar en adelante, es una fuerza en cada uno que crea un bello acto, pero distinto, con respecto a todos. No es nada de nadie, j es alma nuestra, en nuestra alma!

...Ultra es, y será, diga lo que quisiere cada uno decir, tan sólo un ansia de renovación, una potente voluntad de nada definido, enteramente nuestro... Ya se ha dicho mil veces que Ultra no es una escuela; mas dicho está otra vez... el Ultra es invulnerable, porque no es esto ni aquello... ${ }^{4}$.

Podríamos multiplicar los testimonios, pero nos interesa solamente transcribir lo dicho por Guillermo de Torre:

Sólo esta idea elemental de ruptura y avance, sólo este deseo indeterminado y abstracto de iniciar una variación... ya era en principio una solución y un ideal 5 .

Este propósito amplio, indefinido, es el enunciado también en el primer manifiesto ultraísta que hemos transcrito más arriba.

Podemos distinguir en el ultraísmo dos vertientes: la de destrucción de las formas ya infecundas y caducas (dirección ésta estrepitosa y vandálica, común a los movimientos vanguardistas europeos). La otra vertiente, ¿hasta qué punto lograda o fracasada?, la positiva: anhelo de encontrar nuevas formas, nuevos medios de expresión para un espíritu también nuevo.

- 3 Cansinos-Asséns, R., "Liminar", en Cervantes, enero 19ig, pág. 2.

4 "Protesto en nombre de Ultra", en Cervantes, set. 1919, pág. 146.

5 Literaturas..., pág. 46. 
Pero a este simple anhelo había que encarnarlo. Para ello se respiraron los principios generales que flotaban en el aire vanguardista europeo, se espigaron rasgos, principios, intenciones, procedimientos, temas no del acervo común de las escuelas o movimientos hermanos, o de algunos en particular.

Aunque Pedro Luis Gálvez niega toda influencia en el nacimiento de Ultra, y nos dice con gracia que de él se podría decir lo que las madres mienten a sus hijos: "nació en una canastilla de flores" ${ }^{6}$, la verdad es que, como nos dice Dámaso Alonso, "el complejo ultraísta se pone ropas hechas, y casi todas se han hecho fuera de casa". ". Guillermo de Torre lo reconoce así cuando dice que el movimiento

aspira a condensar en su haz genérico una pluralidad de direcciones entrecruzadas. De ahí que el Ultra se nos presente como vértice de fusión potente a donde afluyen todas las tendencias estéticas mundiales de vanguardia... ${ }^{8}$.

Ya hemos dicho que una de las aspiraciones ultraístas fue la de poner el reloj de España con el meridiano literario de Europa, "vivir al dia, a la hora, al minuto" ", impulsados por afanes "nunistas" (de ahora).

Uno de los caracteres de los "ismos" europeos fue la estrecha relación internacional. Nunca como entonces los españoles mantuvieron $\tan$ estrechas relaciones personales y literarias con los escritores de otras naciones de Europa. Guillermo de Torne

6 "De la fiesta del Ultra", en Grecia, núm. XVI, año II, Sevilla, 20 mayo 1919, pág. 4.

7 Poetas españoles contemporáneos, Madrid, 1958, pág. 176.

8 Literaturas.... pág. 48. Cf. afirmaciones parecidas en el Manifiesto vertical: "En nuestro vértice equidistante desembocan...", etc. Según el manifiesto DADÁ (Paris, 12 enero 1921): "L'ultraïsme recommande le mélange de ces 7 choses artistiques" (cubismo, expresionismo, simultaneísmo, futurismo, unanimismo, neo-clasicismo, paroxismo) Cf. apéndice de documentos.

9 TORRE, G. DE: Literaturas..., pág. 48. 
y Cansinos-Asséns mantenían correspondencia con los vanguardistas franceses. En los manifiestos DADÁ se hacía alusión al ultraísmo. En el Boletín DADÁ núm. 5 se daba una lista de setenta y siete presidentes del movimiento y entre ellos se incluían los nombres de Cansinos, Guillermo de Torre y Lasso. de la Vega.

ESTRUCTURA COMÚN DE LA L I R I C A DE VANGUARDIA.

¿Qué debe el ultraísmo a cada una de estas escuelas? Esto es ya más difícil de determinar porque hay una dificultad previa: la imposibilidad de establecer límites nítidos entre ellas. La lírica contemporánea tiene una estructura común, que enráza en el romanticismo y se forja a través de la magia revolucionaria de Baudelaire, Rimbaud y Mallarmé, hasta desembocar en el siglo XX. Todas las escuelas de vanguardia poseen un. acervo común, un árbol hacia el cual todas estiran la mano para recoger frutos, a veces en buena armonía, otras discutiendo agriamente el derecho de propiedad (recuérdense las polémicas entre Marinetti y los dadaístas; o entre Reverdy, "pater" del cubismo y Huidobro "descubridor" del creacionismo; o las discusiones entre Huidobro y Guillermo de Torre...).

Por otra parte, la orgía de "ismos", los numerosos "movimientos" poéticos que proliferaron en aquella época, no son sólo distintas facetas de una lírica de común estructura, sino que están confundidos incluso en sus orígenes históricos: 'Apollinaire hizo a los futuristas italianos algún manifiesto de los. más vivos; poetas cubistas colaboraron en las primeras publicaciones dadaístas; Huidobro colaboró un tiempo en NordSud, revista dirigida por Reverdy, etc.

Antes de tratar de discriminar, en la medida de lo posible. qué debe el ultraísmo al futurismo, al cubismo, al creacionismo, al expresionismo o a algún otro "ismo", |veamos breve- 
mente cuáles son los rasgos comunes y esenciales de las literaturas de vanguardia 0 , más exactamente, del arte de vanguardia ${ }^{10}$, ya que existe estrecha relación entre literatura. música y artes plásticas.

Trataremos de sistematizar esquemáticamente esos caracteres. Ortega y Gasset ha hablado de "deshumanización del arte" ", si bien, como puntualiza Guillermo de Torre (Literaturas..., págs. 279-280), es exagerada la pretensión deshumanizadora que les atribuye Ortega ya que jamás el arte, expresión del hombre, puede prescindir enteramente de quien le da vida y sentido.

En el nuevo arte hay, sí, una evasión de la realidad. Se evitan las semejanzas entre la obra poética y el mundo externo, se desprecia la expresión de las eternas pasiones del hombre. Se proscribe el tema, la anécdota, la narración de un asunto y toda intención didáctica o confesional: Desaparece o tiende a desaparecer el "yo" autobiográfico, se lo reemplaza por un "yo" artificial. Se busca un arte "artístico" cerrado en sí mismo, creacionista, que da sustantividad a paisajes internos. $y$ subjetivos, a ideas y seres del mundo interior, a abstracciones inexistentes, con afán demiúrgico. Se crean ultra-objetos, mundos nuevos, autónomos, distintos a los reales. Surge un ultrarealismo para el cual no son válidos el tiempo y el espacio (superposiciones temporales y espaciales; el hombre puede tocar un astro o un pájaro picotear una estrella, se pasa sin transiciones de unas partes del espacio a las más alejadas). Se destruyen relaciones causales o se crean entre cosas completamente dispa-

10 Sobre características del arte de vanguardia Cf. ORTEGA y GASSET, JOSÉ : Op. cit.

TORRE, GUILLERMO DE: Literaturas... EPSTEIN, JEAN: La poésie d'aujourd' hui, Paris, 1920. FRIEDRICH, Hugo: Estructura de la lirica modema, Barcelona, 1959 y otras obras citadas en la bibliografía general.

11 Op. cit., págs. 353 y sigs. 
res. Se equipara lo concreto con lo abstracto y se llega así a una enigmática no-realidad.

Este camino desemboca en el concepto de poesía pura, del poema cerrado sobre sí mismo, que no comunica ni experiencia, ni verdad, ni emoción, que no "significa" sino que simplemente "es"/ ¿De qué varita mágica se vale el poeta para realizar todos estos prodigios? Su instrumento es la palabra y la fantasía ilimitada. Por medio de la palabra destruye la realidad y transforma al objeto en idea pura, en esencia espiritual, en juego de ensueños plurivalentes. La sugestión sonora y asociativa del lenguaje importa más que su significado, los versos suenan e insinúan, más que dicen. La palabra tiene múltiples ecos y se carga de contenidos misteriosos, de significados equívocos, no unívocos, de reflejos interiores. Esta palabra mágica encierra fuerzas más poderosas que las ideas - según estos poetas- cuando se la despoja de su contenido, de su significado utilitario, del peso de clisés y se la utiliza en cambio para decir lo nunca dicho. Las palabras dirigen así al poema, el poeta se deja llevar por ellas, por su sonoridad y sus sugerencias y la lírica se convierte en un juego entre lenguaje y fantasía. Esta poesía no es inteligible y como se abre a múltiples interpretaciones $_{2}$ el lector se convierte en un co-creador. Pero por este camino se enfrenta con su mayor peligro: una poesía que persigue mundos fantásticos, azarosos y caóticos, imágenes que nunca podrán ser vistas realmente por ojos humanos, fragmentarias, disonantes, contradictorias, absurdas, incongruentes, sotpresivas, arbitrarias, sustantivas, puede llegar - si se pieide toda clase de comunicación - a un punto en que se destruya a sí misma.

Esța intención creacionista explica el culto a la "imagen creada" que se convierte en el fruto más deseado de la nueva lírica. Se persigue la imagen absoluta, con sustantividad propia, que ya no tiene por función comparar, transponer, adornar, sino sustantivar. 
Predomina, como observa Ortega y Gasset (op. cit., página 374) la imagen que disminuye el objeto, no la que lo ennoblece (el sol es el balón para jugar al fútbol, o, según el ejemplo de Ortega, el árbol es la escoba para barrer el cielo).

Paralelo al ultra-realismo hay un infra-realismo que busca la evasión de lo real por otro camino: el de alterar su jerarquía destacando lo mínimo, desmenuzándolo en detalles, (por ejemplo la greguería de Gómez de la Serna).

Esta poesía tiene como centro irradiador un fuerte individualismo, subjetivismo e irracionalismo; se quiere expresar ensueños, fuerzas pre-racionales, abstracciones, estados de ánimo no descritos sino sugeridos.

Este desprecio de la comunicación de un contenido coherente, lleva al hermetismo, a la oscuridad, al misterio.

Por este motivo él se hace impopular, la masa no lo en: tiende ni lo acepta. Tampoco a los poetas les interesa la popularidad, por el contrario: se jactan de la incomprensión del público y aman su torre de marfil. Esta actitud llega a la provocación del escándalo y del desconcierto por medio de actos públicos desafiantes y de gritos iconoclastas. Se siente el placer de desagradar.

Contradictoriamente, el amor por el arte, el ponerlo por encima de la vida, el buscar el arte.por el arte lleva a cierto desdén por el arte: en primer lugar, por todo el arte pasado, el cual es combatido agresivamente (desprecio a las academias, p. e.). En segundo lugar, el artísta deja de ser un inspirado, un profeta, un misionero y el arte pierde trascendencia, formalidad y patetismo, y se convierte en un juego, es un arte "inútil": es lo que Ortega llama "sentido festival y deportivo del arte" (Cf. op. cit., págs. $3^{81-3^{82}}$ ). Las obras de la época reflejan este espíritu jovial, burlón, cómico. El arte se burla de sí mismo, se ironiza, confraterniza con el humorismo.

$\mathrm{Y}$ por último, para completar esta síntesis de los caracteres generales de la lírica que estudiamos, enumeremos otras notas: 
exaltación de la civilización occidental y de los progresos técnicos (maquinismo, descubrimientos científicos físico-químicos). Exaltación del presente con conciencia de su fugacidad y, como consecuencia de la velocidad y de los medios modernos de comunicación, un espíritu cosmopolita, un sentirse fraternos de todos los pueblos del mundo ${ }^{12}$. Las alusiones a las grandes cosmópolis ("ciudades tentaculares", dice el "Manifiesto Vertical" de Guillermo de Torre) con sus multitudes, prisas y ajetreos.

Estas son, en resumen, las características comunes a las literaturas de vanguardia. Se dan reiteradamente aunque podamos señalar excepciones 0 internas contradicciones (excesivo subjetivismo en contradicción con una intención realista al tratar de reflejar los fenómenos de la vida contemporánea; repetición de ciertos temas - los citados, por ejemplo- a pesar de que se pregona la no existencia del tema; exaltación del arte y desjerarquización del arte, etc.).

El ultraísmo quiso orientar la poesía española según estas direcciones del arte europeo de vanguardia. Con frecuencia estos intentos no pasaron de tales, a pesar de los empeñosos esfuerzos de los ultraístas. Es verdad que en la primera época a veces encontramos confraternizando en un mismo número de Grecia un poema dedicado a Rubén Darío con una traducción de Max Jacob (Cf. núm. VIII, I919) o un poema al tranvía junto a otro que canta al amor con formas tradicionales. Es verdad también que la búsqueda del arte nuevo no pasó con frecuencia de ser un esforzado remedo, una concienzuda apli-

12 Aunque también se expresa lo nacional: Cf. el ensayo de Apoilinaire: "El espíritu nuevo y los poetas", en Cosmópolis, I, enero 1919, págs. I7 a 28.

Cf. Fervor de Buenos Aires, de Borges y en general el fervor nacional de los ultraistas argentinos. 
cación de fórmulas, pero mucho de esto se dio también en los otros "ismos" europeos, sumado a un frecuente intento de reírse del público y burlar su buena fe. (Los ultraistas en cambio tomaron sus tareas renovadoras muy en serio.)

RELACIÓN DEL ULTRAÍSMO CON EL FU. TURISMO, EL CUBISMO, EL DADAÍSMO

Hecha pues esta breve enumeración de los caracteres generales vanguardistas, tal vez sea mejor replantear nuestra primitiva pregunta: "¿qué debe el ultraísmo a cada una de las escuelas extranjeras?" "y preguntarnos cuáles son las que sirven de conductos para que los distintos aspectos parciales lleguen a él. En el ultraísmo influyeron sobre todo el cubismo, el futurismo, el dadaísmo, el creacionismo $y$, en pequeña medida, el expresionismo.

No nos corresponde en este trabajo hacer una historia detallada de estos movimientos. Recordemos brevemente que la prioridad cronológica de las escuelas del siglo XX llamadas "de vanguardia", corresponde al futurismo, creado en Italia por Marinetti en 1909 y que en Francia fue Apollinaire quien, al recoger e intensificar la trayectoria recorrida por la lírica desde el romanticismo y especialmente desde el simbolismo, posibilita y nutre a los nuevos "ismos".

Guillermo de Torre en el citado estudio preliminar a las obras de Apollinaire ${ }^{13}$ habla de la influencia de este autor sobre los ultraístas. Las revistas del movimiento publicaron sus poemas y le dedicaron algunos homenajes ${ }^{14}$. La extraña dispo-

13 Págs. 22 y sigs.

14 Dfez-Canedo, E., "Guillermo Apollinaire", en Grecia, núm. XX, rgrg. páginas I y 2.

TORRE, G. DE, "Epiceyo a Apollinaire", en Grecia, núm. XXXVIII, 1920. páginas 13 y 14 .

BL. ULTRAfSMO. -7 
sición tipográfica de los poemas del Ultra procede fundamentalmente de Calligrammes.

Imposible o aventurado sería tratar de filiar uno a uno los caracteres ultraístas. Fue posiblemente del futurismo de quien el ultraísmo tomó el culto a la velocidad y a las máquinas del siglo $\mathrm{XX}^{15}$. Pero este canto a las bellezas occidentales, que tiene su antecedente en Whitman, pudo llegar también por otras vías.

¿Podemos afirmar que las actitudes iconoclastas, los gritos contra las academias, la voluntad de escándalo, fueron tomadas, del futurismo y no, por ejemplo, del dadaísmo?

¿No sería aventurado afirmar que el irracionalismo, el abandono a las sugerencias asociativas o sonoras de las palabras llegan exclusivamente a través del cubismo, o de DADÁ?

Análogas dudas se nos plantearían si tratáramos de establecer la paternidad del sentido del humor, la arbitrariedad, la deificación del absurdo, las cabriolas mentales desconcertantes, la actitud jovial frente a la vida.

La influencia de DADÁ es evidente en las boutades (algunas parecen casi calcadas) y en ciertas ostentaciones nihilistas.

$\mathrm{El}$ aporte "expresionista" llega al ultraísmo por J. L. Borges. Este joven argentino vivió durante los años de la guerra en Suiza, refugio de numerosos escritores alemanes, aprendió allí la lengua, conoció la nueva poesía germana y recibió su influencia.

En Cervantes, marzo de 1919, un artículo de Jean Royère, con motivo de la muerte del poeta. En Cosmópolis, 1, enero 1919, págs. 17 y sigs. se publicó el ensayo de Apollinaire: "El espíritu nuevo y los poetas".

En Ultra, núm. 19, dic. 1921: Gulllermo DE TORRE: "Un poema discu, tido de Apollinaire" (sobre la gestación de "Les fenêtres", etc.).

15 En Grecia, núm. XIV, 1919, págs. 6 y 7 se publicó "La canción del automóvil" de Marinetti y un comentario sobre el autor. En la primera fiesta ultraísta se leyeron también sus poemas. 


\section{ULTRA Y EL EXPRESIONISMO}

Es la expresionista, dentro del concierto vanguardista, aunque no se distingue esencialmente de la de los otros "ismos", una poesía más grave, de más contenido ideológico y mayor preocupación social. Borges la definía diciendo: "es la tentativa de... superar la realidad ambiente y elevar sobre su madeja sensorial y emotiva una ultrarrealidad espiritual. Su fuente la constituye esa visión ciclópea y atlética del pluriverso que ritmara Walt Whitman, partiendo a su vez de Fichte y Hegel" " ${ }^{16}$. Los poetas expresionistas, con tono patético que contrasta con el irónico de otros poetas de Europa, llaman a la fraternidad universal ("Mi corazón es amplio cual Alemania y Francia reunidas...", dice en un poema W. Klemm) ${ }^{17}$. El expresionismo buscaba cristalizar la visión del artista por medio de los elementos tomados de la naturaleza, materializar la idea por medio de la idealización de la materia ${ }^{18}$, comunicar los estados interiores al mundo sensible,

En las revistas ultraístas Borges tradujo y glosó varias veces poesias expresionistas, dio noticias sobre sus autores y sobre las características del movimiento ${ }^{19}$ y publicó algunas poesías propias que revelan cierta influencia. En Ultra (núm. 16, 20 octubre 1921) comenta la antología expresionista Die Aktions. Lyrik, 1914-16, Berlín, y nos dice que en ella se eslabonan

16 Citado por GuIllermo de TORRE, en Literaturas.... pág. 354 -

17 Cf. "Lírica expresionista" nota y traducción de J. L. Borges, en Grecia, núm. L, año III, Madrid, I de nov. 1920, págs. 10 y II.

18 CE. Pansaers, Clément: "La pintura expresionista alemana", en Cosmópolis, núm. 4I, tomo XI, año IV, Madrid, mayo 1922, págs. 161-162.

19 Cf. BORGIS, I. L.: "Antología expresionista", en Cervantes, oct. 1920, págs. 100 a 112 (Poesias de Erns Stadler, Johannes Becher, Kurt Heynicke, W. Hahn, A. Vagts, W. Klemm, A. Stramm, L. Schreyer, H. Stummer). .

"Lírica expresionista" (nota y traduc. de Borges), en Grecia, núm. L, 1920, págs. 10 y 11 . El citado artículo en Ultra, núm. 16, 1921, ete. 
poemas conscientes, duros, dolorosos, forjados en el fatalismo de las trincheras en Polonia, Rusia y Francia. Presentan - nos dice- dos aspectos, el documental, que apunta instantes de la guerra; el otro, muestrario del expresionismo lírico en sus albores. Transcribe algunos ejemplos:

De pronto no se sabe por qué está sin segar el trigo y las patatas se [pudren, $y$ por qué hay formas pardas que hacia nosotros avanzan enormes en [la tarde $y$ alzan las manos en alto como mendigos extáticos.

(H. Plagge)

Chillan las balas

pájaros astrales

de una fauna metálica sin sangre.

(J. T. KeLLeR)

Las ametralladoras charlan todavia un rato y se van entretejiendo en las horas larguisimas.

Pero a las seis de la mañana bebe el inglés su café.

Entonces podremos enterrar a nuestros muertos.

(W. KLEMM)

Borges publicó en las revistas ultraístas algunas poesías en esta línea, aunque, como extranjero, siente el dolor de la guerra con menos hondura y se complace más en algún hallazgo metafórico.

\section{TRINCHERA}

Angustia.

En lo altisimo una montaña camina

Hombres color de tierra naufragan en la grieta más baja El fatalismo unce las almas de aquéllos 
que baĩaron su pequeña esperanza en las piletas de la noche.

Las bayonetas sueñan con los entreveros nupciales

El mundo se ha perdido y los ojos de los muertos lo buscan

El silencio aúlla en los horizontes hundidos ${ }^{20}$.

\section{EL ULTRAÍSMO Y EL CREACIONISMO}

La creacionista es, sin duda, de todas las escuelas de vanguardia, la que dio a Ultra mayores aportes. Más aún, como hemos visto fue el paso de Huidobro por Madrid el chispazo que encendió la voluntad de un "ultraísmo" literario Por la importancia del creacionismo dentro del movimieñto vanguardista español, su estudio merece un capítulo aparte. Sin embargo, un análisis detenido de esta escuela, de la obra de sus poetas y especialmente de su "creador", Vicente Huidobro, sería por sí solo motivo de un largo trabajo; por lo tanto nos limitaremos a considerar sus rasgos principales y sus relaciones con el ultraísmo.

No entraremos aquí a dilucidar hasta qué punto es exclusiva la paternidad de las doctrinas creacionistas que se atribuye Huidobro. Este punto ha dado origen a interminables polémicas entre Huidobro, Reverdy, Guillermo de Torre y otros.

No podemos afirmar que la pretensión demiúrgica, creadora del poeta, el relieve dado a la imagen creada y dotada de vida autónoma, aquello de "crear un poema como la naturaleza crea un árbol", sea patrimonio exclusivo del creacionismo, ya. que son principios que flotaban en el ambiente vanguardista.

Pero no cabe duda de que Huidobro despertó en España la voluntad "ultra" y de que sus teorizaciones y poemas señalaron medios para concretarla ${ }^{21}$.

20 En Grecia, núm. XLIII, año III, Madrid, I junio 1920, pág. 5.

21 Aunque, como hemos visto en capítulos anteriores, existieron precursores y muchos de los procedimientos de la lírica moderna se fueron gestando a través de un proceso poético que arranca del romanticismo. 
Cuando estuvo Huidobro en Madrid en 1918, procedente de París, dio a conocer sus inquietudes vanguardistas, sus libros y revistas, relacionó a los españoles con artistas extranjeros que residían en Madrid y dio datos bibliográficos o señas personales para establecer correspondencia con otros escritores europeos. Federico de Onís cita a Gerardo Diego:

En sucesivos viajes a España traía a los neófitos las buenas nuevas de la hora europea... La influencia personal de Huidobro fue intensa en los primeros momentos del ultraís$\mathrm{mo}^{22}$.

En otra parte Gerardo Diego compara la influencia de los viajes de Huidobro con la que ejercieron los de Rubén Darío en el panorama de la literatura española ${ }^{23}$.

Guillermo de Torre tanto en su Estudio preliminar y prólogo a las poesías de Apollinaire como en Literaturas europeas de vanguardia nos habla del papel fundamental desempeñado por el poeta chileno en el nacimiento de Ultra, pero afirma que el creacionismo no agota las direcciones del ultraísmo ${ }^{24}$, refu. tando así a Huidobro que consideraba a éste como una degeneración de su escuela (L'Esprit Nouveau, núm. I).

Muchas veces se ha identificado al ultraísmo español con el creacionismo. Sin embargo, el creacionismo es una escuela con un contenido teórico determinado y el ultraísmo, al menos en sus orígenes españoles es - como ya hemos visto- un movimiento abierto a todo lo nuevo, sin determinaciones: Citare-

22 ONis, FEDERICO DE: Antologia de la poesía española e hispanoamericana, Madrid, 1934, pág. I127.

23 Citado por Eduardo Anguita en el prólogo a la Antologia de Vicente Huidobro. Santiago de Chile, 1945, pág. 15.

24 "Y la entronización de la lírica de Huidobro... acabó de evidenciarnos, en efecto, la agonía del ciclo precedente y la necesidad de rebasar sus límites, mas no la de detenernos o limitarnos al espacio de "Poemas árticos". (Página 52). 
mos a Rivas Panedas que en su artículo "Protesto en nombre de Ultra" rechaza insistentemente esa identificación :

...el creacionismo, es algo bien concreto, al menos una cosa muy concreta al lado de nuestro Ultra, que no nos cansaremos de repetir, que no es un dogma ni un modo. El creacionismo si $^{25}$.

Vicente Huidobro había publicado varios libros en prosa y en verso antes de pasar por Madrid. Sus primeras obras están aún dentro del marco modernista, aunque se pueden espigar en ellas, especialmente en $\mathrm{El}$ espejo de agua (Buenos Aires, Orión, 1916), algunos intentos novedosos. Pero es sobre todo a partir de 1917, en París, cuando Huidobro se incorpora plenamente al vanguardismo. Allí conoció y trató a los poetas que cultivaban la nueva lírica. En ese año, 1917, publicó en París Horizon carré y en 1918 en Madrid, cuatro libros breves, de anchos márgenes: Ecuatorial y Poemas árticos, en castellano, y Hallali y Tour Eiffel en francés, el último ilustrado por Delaunay. Estas obras sirvieron a los jóvenes ultraístas como modelo y ejemplificación de las teorías estéticas expuestas por Huidobro.

En la primera página de Horizon carré anunció Huidobro sus teorías: "Crear un poema tomando a la vida sus motivos y transformándiolos para darles una vida nueva $e$ independiente. Nada anecdótico ni descriptivo. La emoción ha de nacer de la única virtud creadora. Hacer un poema como la naturaleza hace un árbol":

Cuando apareció este libro, Huidobro explicó así su título en una carta al crítico y amigo Thomas Chazal:

Horizonte cuadrado. Un hecho nuevo inventado por mi, que no podría existir sin mí. Deseo, mi querido amigo, en-

25 Rivas Panedas, J.: "Protesto en nombre de Ultra", en Cervantes, setiembre 1919. pág. 145 . 
globar en este título toda mi estética, la que $\mathrm{Vd}$. conoce desde hace algún tiempo.

Y a continuación explica cómo por este título consigue: I. ) Humanizar las cosas: el vasto horizonte se humaniza, se hace intimo, gracias al adjetivo "cuadrado"; $\left.20^{\circ}\right)$ precisar lo vago; $\left.3 .^{\circ}\right)$ hacer lo abstracto concreto y lo concreto abstracto; $\left.40^{\circ}\right)$ el horizonte que era poético en sí, que era poesía en la vida, al calificárselo de cuadrado acaba siendo poesía en el arte ${ }^{26}$.

Conceptos semejantes había expresado en el manifiesto "Non Serviam", leído en el Ateneo de Santiago en 1914: el poeta grita a la naturaleza: Non serviam. "Yo tendré mis árboles que no serán como los tuyos, tendré mis montañas, tendré mis ríos y mis mares, tendré mi cielo y mis estrellas" (Cf. el apéndice de documentos). Y en su ensayo de estética: "La creación pura" ("La création pure") publicado en la revista L'Esprit Nouveau en 192.1, habla de tres fases artísticas:

(I) Arte inferior al medio (Arte reproductivo).

2) Arte en armonía con el medio (Arte de adaptación).

3) Arte superior al medio (Arte creativo).

La historia del arte, dice Huidobro, no es sino la historia de la evolución del Hombre-Espejo hacia el Hombre-Dios.

El hombre sacude su yugo, se rebela contra la Naturaleza como antaño se rebelara Lucifer contra Dios, a pesar de que esta rebelión sólo es aparente, pues el hombre nunca estuvo más cerca de la Naturaleza que ahora que ya no busca imitarla en sus apariencias, sino que hace lo mismo que ella, imitándola en el plano de sus leyes constructivas, en la rea-

26 Cf. Huidobro, Vicente: "El Creacionismo", en Manifestes, París, 1925, transcrito en Obras poéticas selectas. Selección y prólogo de Hugo Montes, Santiago de Chile, págs. 277-278. 
lización de un todo, en el mecanismo de la producción de nuevas formas.

No se trata de imitar la Naturaleza, sino de hacer como ella: no imitar sus exteriorizaciones sino su poder exterio. rizador ${ }^{27}$.

Su libro de poemas El espejo de agua comienza con la siguiente:

\section{ARTE POETICA}

Que el verso sea como una llave

que abra mil puertas;

una hoja cae; algo pasa volando;

cuanto miren los ojos, creado sea,

$y$ el alma del oyente quede temblando.

Inventa mundos nuevos y cuida tu palabra;

el adjetivo, cuando no da vida, mata.

Estamos en el cielo de los versos.

El músculo cuelga,

como recuerdo, en los museos;

mas no por eso tenemos menos fuerza;

el vigor verdadero

reside en la cabeza.

¿Por qué cantáis la rosa, oh, poetas?

¡Hacedla florecer en el poema!

27 HuidoBro, Vicente: "La creación pura". Ensayo de estética. Transcrito en Obras poéticas selectas, págs. 244 a 251 . 
Sólo para vosotros

viven todas las cosas bajo el sol.

El poeta es un pequeño Dios ${ }^{28}$.

Y ejerciendo estos poderes creadores se empeña el poeta en transformar el mundo. En uno de sus Poemas árticos (igi8) nos dice:

Hice correr ríos

que nunca ha existido

de un grito elevé una montaña,

$y$ en torno bailamos una nueva danza.

Veremos más detalles de la poética creacionista al analizar la poesía de Huidobro y de otros autores de Ultra que siguieron su escuela.

28 Transcrito en: ONís, FEDERICO DE: Antologia de la poesía española e hispanoamericana, págs. 1128-1129. 


\section{Capítulo IV}

\section{RASGOS CARACTERISTICOS DEL ULTRAISMO}

INTENTOS DE DARLE UN CONTENIDO T E Ó R I C O

El ultraísmo - ya lo hemos dicho- no tue una escuela con un cuerpo orgánico de principios teóricns. De las diversas direcciones seguidas por los distintos autores podemos, sí, extraer un conjunto de características que son las que hemos enunciado como patrimonio de las vanguardias. Aun asi, hay algunos rasgos que se repiten casi sin excepción en todos los poetas, sobre todo el cultivo de la imagen.

Borges, uno de los pocos que procuró dotar al movimiento de un programa, sintetiza así sus principios:

1) Reducción de la lírica a su elemento primordial : la metáfora.

2). Tachadura de las frases medianeras, los nexos y los objetivos inútiles.

3) Abolición de los trebejos ornamentales, el confesionalismo, las prédicas y la nebulosidad rebuscada.

4) Síntesis de dos o más imágenes en una que ensancha asi su facultad de sugerencia. Los poemas ultraicos constan, pues, de una serie de metáforas, cada una de las cuales 
tiene sugestividad propia y compendia una visión inédita de algún fragmento de la vida ?

Observamos que este intento de dotar al movimiento de un contenido teórico es tardío (diciembre de 1921). El manifiesto "Vertical" es anterior (noviembre 1920), pero es difícil descubrir una estética entre las selvas de neologismos que emplea su autor.

LA IMAGEN

Es el resorte principal de la nueva lirica, el tesoro más anhelosamente buscado.

Gerardo Diego en un ensayo juvenil (1919) nos presenta una clasificación de las imágenes según una escala gradual que culmina con la "imagen múltiple" creacionista :

x." Imagen, esto es, la palabra. La palabra en su sentido primitivo, ingenuo, de primer grado, intuitivo, generalmente ahogado en su valor lógico de juicio, de pensamiento. Así, la palabra tierra, ordinariamente tiene un valor estético insig. nificante; pero en los labios absortos del vigía descubridor de América fue el más emotivo de los poemas, la más encendida de las imágenes. Pero es ya difícil desnudar a las palabras ya tan resabidas. Sólo los niños, algunos poetas del pueblo y nuestros creacionistas, por su pureza de intención y su ausencia de ilaciones, logran ocasionalmente el milagro.

2." Imagen refleja o simple, esto es, la imagen tradicional estudiada en las retóricas. La imagen evoca el objeto aludido con una fuerza y una gracia renacidas. También está ya muy restringido el campo de acción, el terreno está ya explorado y agotado. El poeta moderno, para una imagen simple y nueva, tiene que usar cien viejas $y$ renovar las que han perdido ya toda su eficacia.

1 "Ultraísmo", en Nosotros, XXXIX, núm. 151, Bs. As., 1921, pág. 468. 
3." Imagen doble. La imagen representa, a la vez, dos objecos, contiene en si una doble virtualidad. Disminuye la precisión, aumenta el poder sugestivo. Se hallan aisladas en los clásicos; los creacionistas las prodigan constantemente.

$40^{\circ}$ y $50^{\circ}$, etc. Imagen triple, cuádruple, etc. Advertid cómo nos vamos alejando de la literatura tradicional. Estas imágenes que se presentan a varias interpretaciones, serían tachadas desde el antiguo punto de vista como gravísimos extravios, de ogminidad, anfibología, extravagancia, etc. El creasor de imágenes no hace ya prosa disfrazada : empieza a crear por el placer de crear (poeta-creador-niño-dios): no describe, construye; no evoca, sugiere; su obra apartada va aspirando a la propia independencia, a la finalidad de sí misma. Sin embargo, desde el momento en que puedan ser medidas las alusiones y tasadas las exégesis de un modo lógico y satisfactorio, aún estará la imagen en un terreno equívoco, ambiguo, de acertijo cerebral, en que naufragará la emoción. La imagen debe aspirar a su definitiva liberación, a su plenitud en el último grado.

Imagen múltiple. No explica nada: es intraducible a la prosa. Es la Poesía, en el más puro sentido de la palabra. Es también, y exactamente, la Música, que es substancialmente el arte de las imágenes múltiples: todo valor disuasivo, esco. lástico, filosófico, anecdótico, es esencialmente ajeno a ella. La música no quiere decir nada. (A veces parece que quiere; es que no sabemos despojarnos del hombre lógico, 'y hasta a las obras bellas, desinteresadas, les aplicamos el porqué.) Cada uno pone su letra interior a la Música, y esta letra imprecisa. varia según nuestro estado emocional. Pues bien : con palabras podemos hacer algo muy semejante a la Música, por medio de las imágenes múltiples ${ }^{2}$.

2 "Posibilidades creacionistas". en Cervantes, octubre 1919, págs. 26 y 27. 
Casi todos los poetas ultraístas, por influjo sobre todo del creacionismo, persiguieron la imagen "polipétala". Esta plurivalencia se logra resumiendo en una imagen dos o más analogías. Cuando Borges dice: "El sol con sus espuelas desgarra los espejos", sintetiza varios paralelos: "Los charcos de agua helados al amanecer son como espejos. El sol naciente los hiere (los derrite). Sus rayos tibios, por tener el poder de desgarrar, son como espuelas".

Cuando Huidobro nos dice que el espejo "es un estanque verde en la muralla y en medio duerme tu desnudez anclada" (El espejo de agua), la imagen del segundo verso nos da la sensación simultánea y doble de un navío en reposo (surgido por la imagen anterior del espejo-estanque) y de un cuerpo de mujer que se refleja ${ }^{3}$.

Otras veces el poeta lleva más lejos su afán creacionista, disocia la realidad y combina arbitrariamente los elementos así obtenidos tratando de aproximarse a la "imagen pura", autónoma, cerrada en sí. Por ejemplo dice Huidobro en "Casa" (Poemas árticos): "Y un ángel equivocado se ha dormido sobre el humo de la chimenea".

LA TIPOGRAFÍA

La original disposición tipográfica es uno de los rasgos más característicos de los poetas ultraístas.

Por el uso de este procedimiento se pasan las fronteras de la poesía (comunicación de un contenido psíquico determinado por medio de meras palabras, según la definición de Bousoño) ${ }^{4}$ y se buscan efectos visuales como auxiliares de la expresión poética.

3 Cf. Cansinos-Asséns, R., "La nueva lírica", en Cosmópolis, núm. 5 , 1919, pág. 76.

4 Cf. Op. cit., págs. 17 y sigs. 
La tipografía expresiva tiene antecedentes remotos. En la poesía griega y latina se encuentran ejemplos de poemas escritos en forma de aspa, de botellón, de copa, de zampoña, de ara, etc. ${ }^{5}$.

La disposición tipográfica que encontramos a cada paso en las revistas ultraístas -y que, suponemos, causaría verdadera desesperación a los tipógrafos pues se llegó a excesos de originalidad- deriva probablemente del Coup de dés, de Mallarmé, aunque no todos estos poetas lo conocieran. También Marinetti había propiciado la originalidad tipográfica. Daba a las poesías aspectos pictóricos, utilizando colores y caracteres diferentes con código o clave: cursivas para las sensaciones análogas, negritas para las onomatopéyicas, etc.

Otra curiosa invención furturista es la poesía pentagramada. Tal novedad fue "fraguada" por Francesco Cangiullo.

Pero el antecedente más próximo está en la tipografía de los calligrammes de Apollinaire. Este poeta, teórico y defensor del cubismo pictórico y amigo de pintores tar plásticamente las "imágenes" verbales. En L'Esprit Nouveau et les poètés defiende la preponderancia del valor visual sobre el auditivo. (Recordemos que la rima fue proscrita por los nuevos poetas.) Apollinaire busca dibujar lo que sugiere la imagen poética y dispone las letras en líneas verticales, oblicuas, circulares, etc., para representar la lluvia, un surtidor, un corazón, una corona, una corbata y un reloj, un paisaje. hasta un caballo o también - como observa Enrique Díez-Canedo-. "visiones más dispersas, conceptos más abstractos, expresados en formas casi puramente geométricas" 6.

5 Cf. TORRe, Gulllermo DE, Guillaume Apollinaire, pág. 48, y Alonso, Dámaso, Poetas españoles contemporáneos, pág. 247, que citan a su vez, respectivamente, un artículo en L'Esprit Nouveau y la Historia universal de Cantú.

6. Dlez-Canedo, "Guillaume. Apollinaire", en Grecia, núm. XX, 1919. página 2. 
Tenemos además otro antecedente francés de disposición tipográfica complicada: la de Nicolás Beauduin que dispone el poema en tres planos, situando en el centro el núcleo fundamental y en los lados lo secundario.

En la poesía española encontramos procedimientos visuales expresivos que pueden considerarse como precursores de la disposición tipográfica que estudiamos; por ejemplo el encabal. gamiento abrupto en esta poesía de Juan Ramón Jiménez

$$
\begin{aligned}
& \text { "tú te mecias indolentemente, blanca y } \\
& \text { mate..." ? }
\end{aligned}
$$

da la impresión de un reiterado balanceo.

En los autores ultraístas encontramos en primer lugar una disposición tipográfica moderada, que consiste en reemplazar la puntuación (suprimida casi siempre en sus poemas), por blancos y espacios o por versos escalonados. La disposición de las palabras tiene casi siempre una función expresiva:

$$
\begin{aligned}
& \text { La ciudad abierta como un pulpo } \\
& \text { se incrusta a la tierra } \\
& \text { con los mil brazos de sus calles }
\end{aligned}
$$

(H. RIvas, "La ciudad múltiple") ${ }^{8}$

En este ejemplo el primer verso se divide y se abre, para corroborar su significado.

Encontramos un caso análogo en Rivas Panedas:

Lejos lejos

como se me revela ahora nunca oido este somido.

("Lejos", en Ultra, núm. 24, 1922)

7. De "Libros de amor", en Prometeo, núm. 33, 1911.

8 En Ultra, núm. 21, 1922. 
(Se apartan las palabras para intensificar la impresión de lejanía.)

$\mathrm{Y}$ en estos versos caen las palabras, como las hojas :

$Y$ de mi corazón

una

$a$

una

van

cayendo

todas

las hojas

(Gerardo Diego, "Cronos" en Cervantes, febrero 1920, pág. 55)

O esta enhiesta :

$T$

O

$\mathrm{R}$

$\mathrm{R}$

EIFFE L

(Guillermo de TORRE, en Hélices, pág. 33)

Rivas Panedas nos describe la impresión que le producen los postes telegráficos que se suceden en un veloz viaje:

Innumerables IIIIII de palo nos abofetean el rostro inofensivas

enhilando el camino...

("Caricaturas rápidas de mi Ultra", en Grecia, número XXXII, 1919, pág. 4)

Podríamos multiplicar los ejemplos de este tipo.

BL ULTRAISMO. - 8 
Reproducimos (grabado $\mathrm{n}^{\circ} 3$ ) unos versos de Juan Larrea que se reflejan en las aguas de un estanque (en Cervantes, junio 1919, págs. 87 y 88).

Hay ejemplos aún mucho más audaces que sólo se podrían reproducir por medio de fotocopias. Por ejemplo en el "Poema ultraísta" de Ángel Cándiz (grabado n. ${ }^{\circ}$ 4) la "expresividad" tipográfica ha sido llevada al máximo. El poeta abandonado, "hidrópico, solo", vio que era la noche y que todas las estrellas se habían condensado en su ventana. Así lo representa por medio de la tipografía. Para ahorrar trabajo al lector le aclararemos que las letras-estrellas dicen:

todas las estrellas me miraban con sus ojos frios $y$ titubeantes, todas las estrellas...

Pero esta vez no se trata de un nuevo exceso de originalidad ultraísta. Es un poema que escribió en broma Dámaso Alonso, lo envió a Grecia con un seudónimo que buscaba expresar candidez tanto en el nombre como en el apellido, y poco después comprobó que había sido tomado en serio y publicado...

Estos juegos casi pictóricos permitieron incluso hacer "exposiciones" de poemas como la que presentó Vicente Huidobro en París?

RELACIÓN DEL ULTRAÍSMO CON LAS ARTES PLÁSTICAS

Siempre ha existido una correlación entre las artes. Literatura, música, artes plásticas -expresiones de una cultura, de un espíritu, de una época determinada - aparecen signadas por rasgos comunes. Sin embargo esta relación es particularmente estrecha en el período que estudiamos.

9 Cf. Montes, Hugo, Prólogo a Vicente Huidobro, Obras poéticas selectas, Santiago de Chile, 1957, pág. 12. 
No haremos consideraciones teóricas sobre la unidad estructural entre la poesía y la pintura de vanguardia : muchos de los principios que enunciamos como característicos de la lírica son aplicables a las artes plásticas (evasión de la realidad, creacionismo, etc.). Mencionaremos, sí, brevemente, la estrecha relación humana entre los distintos artistas. Poetas y artistas plásticos aparecen fraternalmente unidos, incluso por amistades personales. Los escritores prologan los catálogos de las exposiciones y las comentan amistosamente en sus publicaciones.

En París, en rincones bohemios de Montmartre, en algún bistrot de la rue Ravignan o en el Bateau Lavoir, se reunian Picasso, Braque, Rouault, Léger, Max Jacob, Apollinaire, Reverdy...

Apollinaire dedicó a los cubistas su libro Méditations esthétiques, defendió sus principios en conferencias, escribió prefacios para sus catálogos, relacionó algunas de sus poesías con "Les fenêtres" de Delaunay. Blas Cendrars y Pierre Reverdy intentaron realizar transcripciones literarias de los principios teóricos del cubismo pictórico.

Los pintores, a su vez, ilustraban las ediciones literarias y retrataban con frecuencia a los poetas. Max Jacob, Reverdy, Breton, Apollinaire, Huidobro, fueron retratados por Picasso y Juan Gris. Delaunay ilustró Tour Eiffel, de Huidobro y Juan Gris el Horizon carré.

Algo parecido ocurrió en España. Un grupo de pintores tuvo estrecha relación con el ultraísmo: el uruguayo Barra-. das; los esposos Delaunay ${ }^{10}$, la argentina Norah Borges; los polacos Paszkiewicz y Wladislaw Jahl y, más tardiamente, Vázquez Díaz y Francisco Bores. (Véanse aqui los grabados números 5 y 6 .)

10 Sonnia era rusa y Roberto, francés. Éste cultivó el "simultanismo" y ganó reputación, sobre todo,con sus "Ventanas" y con sus cuadros sobre la torre Eiffel. 
La revista Grecia incluye con frecuencia xilografías de los "novísimos". De estos artistas son las "muequeantes" portadas de Ultra. En Alfar se acentúa más aún la relación, aparecen reproducciones de artistas españoles y extranjeros y artículos críticos sobre ellos. Como esta colaboración duró hasta los últimos números de la revista se puede observar la evolución de los artistas.

Los cuadros de Jahl y Paskiewicz adornaron las paredes de Parisiana en aquella velada. Los carteles de Jahl anunciaron la reunión del Ateneo.

Pintores y poetas formando una estrecha falange emprendieron la cruzada de "lo nuevo". 


\section{Capítulo $\mathrm{V}$}

\section{POETAS DEL MOVIMIENTO}

\section{ALGUNAS CONSIDERACIONES PREVIAS.}

Casi todos los poetas de Ultra son figuras de segundo o tercer orden, aunque hay excepciones valiosas, como señalaremos. La presencia de algunos buenos poetas dentro del movimiento (especialmente en su vertiente creacionista), los aciertos parciales en los poemas de los demás, el valor renovador y en cierta medida precursor, justifican un estudio panorámico de estos autertes.

Guillermo de. Torre plistingue entre los ultraístas "per natívitatem" y los que procedían del modernismo. Hace además una distinción entre influyentes e influidos: aquellos que aportaron matices peculiares al espíritu nuevo (sabemos que estos matices fueron importados del extranjero) y aquellos que intentaron prolongar las aportaciones iniciales, unas veces con personalidad, otras con superficial espíritu mimético !

Es difícil hacer una clasificación de los autores ultraístas. En las revistas se aceptaban colaboraciones sin discriminación, poco a poco se fueron agregando nombres, algunos no lograron despojarse del lastre modernista, otros cultivaron paralelamente

1 Cf. Literaturas..., pág. 6r. 
la antigua y la nueva modalidad, o, poco después de incorporarse al ultraísmo, se arrepintieron y desertaron. Hay además, en torno al movimiento, una serie de figuras tangenciales que le brindaron su apoyo y simpatía (Bacarisse, por ejemplo) o que hicieron algún ensayo esporádico en el nuevo estilo, pero sin pertenecer a él.

Existen también grandes dificultades para elaborar juicios - señalar, con probabilidad de acierto, los caracteres de cada uno de los poetas ultraístas, por ser su obra escasa y por estar dispersa en revistas o en libros - la mayor parte olvidados- y por tratarse muchas veces de tanteos indecisos y volubles, de personalidades sin cristalizar o de poetas que - por aplicar idénticas fórmulas - no tienen estilo propio. Con intención documental, ya que es tan difícil el acceso directo a este período de la historia literaria española, transcribimos algunas poesías recogidas en las revistas o en los pocos libros que dio Ultra en España.

Cuando se trate de autores que tienen una trayectoria literaria anterior o posterior al ultraísmo, trataremos de limitarnos a la consideración de la obra comprendida en el periodo "oficial" del movimiento, cuando éste era un grupo más o menos orgánico.

Comenzaremos por los poetas "creacionistas".

VICENTE HUIDOBRO

Hemos tratado ya de aclarar las relaciones existentes entre el creacionismo y el ultraísmo. Aunque el poeta chileno no esté dentro del ultraísmo, haremos un breve estudio de su obra. Éste se justifica por la influencia de Huidobro en el movimiento, por la frecuente inclusión de sus poesías en Grecia, Cervantes $\mathrm{y}$ otras revistas, $\mathrm{y}$ porque un rápido análisis de su obra poética nos ayudará a ampliar la enumeración de los caracteres 
del "creacionismo", que hasta ahora hemos extraído sólo de la teoría huidobriana.

Los libros que influyeron sobre los poetas españoles fueron: Horizon carré (1917), Hallali (1918), Ecuatorial (1918), Tour Eiffel (1918) y Poemas árticos (1918).

Características comunes a estos libros son el esquematismo, la desintegración de la realidad (cada poesía es un baúl de cosas heterogéneas puestas en un mismo plano), la falta de sentido estructural (aunque hay un débil nexo temático en Tour Eiffel, Ecuatorial y Hallali), la falta de puntuación y la tipografía expresiva.

En las cinco obras se incorporan, aunque no con insistencia, elementos del mundo moderno (técnica, fábricas, máquinas) y se mezclan con los motivos poéticos tradicionales:

\section{AEROPLANO}

\section{Una cruz}

se ha abatido por tierra

Un grito perfora las ventanas

$Y$ se inclina

sobre el riltimo aeroplano.

\section{LA CRUZ DEL SUR}

Es el único avión

que subsiste ${ }^{2}$.

Un caso análogo encontramos en la poesía "Égloga", de Poemas árticos:

2 De Horizon carré, en Obras poéticas selectas, págs. 124-125. 


\section{Sol muriente}

Hay una panne en el motor

$Y$ un olor primaveral

Deja en el aire al pasar

\section{En algún sitio}

$$
\text { una canción }
$$

Por medio de la imagen creacionista une lo dispar, lo concreto y lo abstracto:

Después en el valle sin sol

$$
\text { Un mismo ruido }
$$

La luna y el reloj.

("Luna o Reloj", Poemas árticos)

Canciones cortadas

Tiemblan entre las manos.

("Alerta", Poemas árticos)

El poeta "creacionista" persigue las imágenes irreales. Los pájaros están muchas veces presentes en estas combinaciones de elementos dispares:

Aquella casa

Sentada en el tiempo

Sobre las nubes

$$
\text { que alejaba el viento }
$$

Iba un pájaro muerto.

("Niño", Poemas árticos)

$Y$ en el humo de mi cigarro

había un pájaro perdido

("Égloga", Poemas árticos) 
La golondrina indiferente

Duerme sobre la cuerda de mi violin.

("Cigarro", Poemas árticos)

En tus cabellos se ha dormido

Aquella alondra que voló cantando.

("Bay Rum", Poemas árticos)

El poeta concede al hombre proporciones cósmicas y pone la inmensidad de la tierra y de los astros a su alcance. El hombre y los pequeños seres que lo rodean (pájaros, objetos de la vida cotidiana - sobre todo los cigarros-), se agigantan y en cambio el cosmos se humaniza, se empequeñece ${ }^{3}$ :

Una corona yo me haria

De todas las ciudades recorridas

De todos los rios navegados

Yo me haria un collar

Aspirar el aroma del Monte Rosa

Trenzar las canas errantes del Monte Blanco

$y$ sobre el Zenit del Monte Cenis

Encender en el sol muriente

El último cigarro.

("Exprés", Poemas árticos)

$Y$ cerca del Niágara

que ha apagado mi pipa

3 Este carácter fue asimilado por la poesía posterior : Cf. AlEIXANDRE : “...tus pies remotísimos sienten el beso postrero del poniente, / y tus manos alzadas tocan dulce la luna, / y tu cabellera colgante deja estela en los astros" ("El Poeta". Sombra del Paraiso). Cf. García LorCa: "El Tiovivo", etc. 
Miro las estrellas salpicadas.

$$
\text { ("Cow-Boy", Horizon carré) }
$$

Quién ha desarrollado el arco iris

("Mares árticos", Poemas árticos)

Tan sólo tu cabellera sideral

suelta sobre la tarde

\section{Huir}

hacia el último bosque

$$
y \text { en la noche }
$$

Vaciar tu cabellera sobre el mundo.

("Bay Rum", Poemas árticos)

El Niágara ha mojado mis cabellos

Y una neblina nace en torno de ellos

$Y$ todos los ríos no explorados

Bajo mis brazos han pasado.

Una mano cortada.

Dejó sobre los mármoles

La línea Ecuatorial recién brotada.

(Ecuatorial)

Vemos que para el poeta han desaparecido las leyes espaciales, juega con la geografía y con la astronomía. También desaparecen las leyes temporales:

El vagabundo cuotidiano

recorrió todo el siglo

Iban buscando el prinier día.

("En Marcha", Poemas árticos) 
Y como el espacio y el tiempo, la causalidad es sometida a la arbitrariedad del poeta:

Mi sangre que hizo rojas las auroras boreales

("Vermouth", Poemas árticos)

Un ruiseñor en su cojin de plumas

Tanto batió las alas

que desató la nieve.

("Osram”, Poemas árticos)

Alguien que lloraba

Hacia caer las hojas.

(Ecuatorial)

En la poesía de Huidobro aparece con frecuencia el elemento humorístico, desenfadado e ingenioso. En Tour Eiffel, por ejemplo, que, como nos dice Cansinos-Asséns, "es un poema cívico, tarareado con la desenvoltura y frivolidad aparente de una canción de music-hall, en el que los retruécanos y las gracias traviesas espejean como lentejuelas y las estrofas semejan subir cantando una larga escalera" ${ }^{4}$ :

Mon petit garçon

Pour monter à la tour Eiffel

On monte sur une chanson

Do

re

mi

$\mathrm{fa}$

sol

la

si

do

4 "La nueva lírica", en Cosmópolis, III, núm. 5, 1919, pág. 78. 
O en estos ágiles ejemplos:

El Capitán Cook

Caza auroras boreales

En el Polo Sur

(Ectiatorial)

La cordillera Andina

$$
\text { Veloz como un convoy }
$$

Atraviesa la América Latina.

(Ecuatorial)

Hasta ahora hemos ejemplificado con imágenes sueltas. En otra clase de poesía esta visión fragmentaria, analítica, puede destruir la captación del estilo al viviseccionar el poema. No ocurre así con Huidobro ni, en general, con los poemas "ultraístas" que estudiaremos, ya que sus obras casi siempre carecen de sentido estructural, son más bien collares de imágenes. sin unión o con débil unión temática.

Tampoco es frecuente el nexo emotivo: una única fuente emocional de la cual brotan imágenes aparentemente dispares, pero que sugieren el mismo estado de ánimo ${ }^{5}$. Podemos señalar en Huidobro algún ejemplo:

\section{$\mathrm{N} I \bar{N} \mathrm{O}$}

Aquella casa

Sentada en el tiempo.

Sobre las nubes

$$
\text { que alejaba el viento }
$$

Iba un pájaro muerto

Caen sus plumas sobre el otoño

5 Como el nexo que existe, por ejemplo, en los poemas supetrealistas de Tercera residencia, de Neruda. 
Un niño sin alas
Mira en la ventana $\left\{\begin{array}{l}\text { El balandro resbala. } \\ Y \text { bajo la sombra de los mástiles } \\ \text { Los peces temen trizar el agua }\end{array}\right.$

Se olvidó el nombre de la madre

Tras la puerta que bate

como una bandera

El techo está agujereado de estrellas

El abuelo duerme

Cae de su barba

Un poco de nieve.

(en Poemas árticos)

En esta poesía las nubes que se alejan, el pájaro muerto, sus plumas que caen sobre el otoño, el niño sin alas, el olvido del nombre de la madre, la puerta que bate insistentemente, la barba cana, son elementos que sugieren la tristeza y soledad del niño.

No alargaremos más este estudio y dejaremos al poeta que quiso "cantar sobre las lejanías desatadas", para acercarnos a los que de él aprendieron el "cántico nuevo".

\section{GERARDO DIEGO}

Mucho se ha hablado de la dual inspiración de Gerardo Diego: la de los versos humanos y la de los versos creacionistas:

Versos tradicionales

$y$ versos nuevos, raros $y$ diversos.

("Versos", Imagen) 
Los libros publicados entre 1920 y 1925: El Romancero de la novia (1920), Imagen (1922), Soria (1923). Manual de espumas (1924), Versos humanos (1925), reflejan àlternativamente esas tendencias e incluso se dan en un mismo libro. Son sus "versos nuevos" los que ahora nos interesan.

Gerardo Diego participó en el ultraísmo con una clara posición creacionista.

Antes de conocer el Ultra ya había hecho ensayos, en su Santander, de una poesía nueva. Llegó a Madrid en I9I9. Cansinos-Asséns, en La meva literatura, se refiere a su aparición en el café Colonial. Colaboró en las revistas del movimiento, dio una conferencia en el Ateneo de Santander sobre la nueva lírica, participó en la velada de Parisiana.

El ultraísmo español -o más exactamente el creacionismo-, le debe sus dos mejores libros: Imagen (1922) y $\mathrm{Ma}$ nual de espumas (1924). De ellos nos-dice Dámaso Alonso: "...de todo aquel vocinglero estrépito de Ultra lo único que nos queda son esos dos libros, juveniles, primaverales, llenos de ingenio, de fuerza intuitiva, pero también de fresca y jugosa emoción" 6 .

El mismo Gerardo Diego nos dice cuáles son sus intenciones :

Salto del trampolin

De la rima en la rama

brincar hasta el confin

de un nuevo panorama.

Partir del humorismo

funámbulo y acróstico,

$y$ cabalgar el istmo

del que pende lo agnóstico.

6 Op. cit., pág. 247. 
La garganta estridente;

el corazón maduro

$y$ desnuda la frente

ávida de futuro.

$Y$ un asirse $y$ plegarse

a la música hermana

para bienorientarse

en la libre mañana.

Repudiar lo trillado

para ganar lo otro.

$Y$ hozar gozoso el prado

con relinchos de potro.

$Y$ asi ved mis diversos

versos de algarabia.

Versos

versos

más versos

como canté algún día.

("Salto del trampolín", Imagen)

He aquí enunciados, no sólo propósitos renovadores, sino también varios de los caracteres de los "versos nuevos" de Gerardo Diego: funámbulo humorismo, estridencias juveniles, ritmo, y -a diferencia de otros poetas "nuevos"- no desprecia la rima.

El contacto con la obra de Vicente Huidobro proporcionó al poeta el càuce de una nueva técnica. Los versos de Gerardo Diego nos ofrecen imágenes creacionistas de originalidad poderosa y múltiples sugerencias : combinaciones de elementos dispares relacionados con verdadero acierto. El poeta se siente contagiado del ímpetu creador predicado por Huidobro: 


\title{
CREACIONISMO
}

\author{
A mi Virgilio \\ Eugenio Montes
}

\author{
¿No os parece, hermanos, \\ que hemos vivido muchos años en el sábado? \\ Descansábamos \\ porque Dios nos lo daba todo hecho. \\ $Y$ no haciamos nada, porque el mundo \\ mejor que Dios lo hizo... \\ Hermanos, superemos la pereza \\ Modelemos, creemos nuestros lunes, \\ nuestro martes, $y$ miércoles, \\ muestro jueves $y$ viernes... \\ Hagamos muestro Génesis. \\ Con los tablones rotos. \\ Con los mismos ladrillos, \\ con las dormidas piedras, \\ levantemos de nuevo nuestros mundos. \\ La página está en blanco: \\ "En el principio era..." ?
}

Con los elementos desarticulados de la antigua realidad, con las palabras despojadas de significado unívoco y abiertas a nuevas sugerencias, el poeta levanta nuevos mundos. Esta poesía creada no tiene doble fondo, no "significa" otra cosa. Las imágenes se suceden ágilmente, con tono juvenil, ingenuo y humorístico. No siempre existe un hilo temático:

7 Grecia, núm. XIX, pág. 7 y en Imágenes. 


\title{
A $\mathrm{HOGO}$
}

Déjame hacer un árbol con tus trenzas

Mañana me hallarán ahorcado

en el nudo celeste de tus venas

Se va a casar la novia

del marinerito

Haré una gran pajarita

con sus cartas cruzadas.

$Y$ luego romperé

la luna de una pedrada

Neurastenia, dice el doctor

Gulliver

ha hundido todos sus navios.

Codicilo: dejo a mi novıa

un puñal y una carcajada.

(en Imagen)

Otras veces la inspiración es más seria y emocionada:

\author{
$\AA$ N G E L U S \\ SENTADO en el columpio \\ el ángelus dormita
}

Enmudecen los astros y los frutos

EI. ULTRAISMO. - 9 
$Y$ los hombres heridos

pasean sus surtidores

como delfines líricos

Otros más agobiados

con los ríos al hombro

peregrinan sin llamar en las posadas

La vida es un único verso interminable

Nadie llegó a su fin

Nadie sabe que el cielo es un jardín

Olvido.

El ángelus ha fallecido

Con la guadaña ensangrentada

un segador cantando se alejaba

(en Imagen)

Vemos en la equiparación entre astros y frutos, en esos hombres cargando con los ríos, la influencia de Huidobro.

Con mucha frecuencia encontramos que se alternan los versos intrascendentes y humorísticos con otros reflexivos, a veces en una misma poesía:

Mi corbata

rueda con su rumor de catarata.

("Círculo", Imagen)

Alguna vez ha de ser

$\begin{aligned} \text { la muerte } & y \text { la vida } \\ \text { me } & \text { están } \\ \text { jugando } & \text { al ajedrez. }\end{aligned}$

(“Ajedrez", en Ultra, núm. 19, 1921) 
(La tipografía enfrenta a las dos jugadoras.)

$$
\begin{aligned}
& \text { Los faroles en hilera } \\
& \text { son estrellas de primera } \\
& \text { de segunda y de tercera } \\
& \text { magnitud }
\end{aligned}
$$

("Nocturno funambulesco", Imagen)

Cada farol es una herida Esta noche es más larga que nunca la vida.

("Calle", en Ultra, núm. 17, 1921)

\begin{abstract}
O se cierra una poesía que expresa un triste estado de ánimo con una burlona comparación:
\end{abstract}

\title{
F R A C A S O
}

Todo llora en la tarde alicaído.

El paisaje es como un sauce

llorón

Brazos de plomo

Tierra imán

Eucaliptus, cabelleras

de mujeres decapitadas.

Todo ha fracasado,

$Y$ el alma se nos cae

-oh máxima tragedia-

en un derrengamiento

de medias arrugadas.

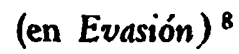

8 Esta poesía es posiblemente anterior a la influencia creacionista, no está incluida en Imagen, pero sí en una reciente edición separada de Evasión, Caracas, 1958. 
Si hiciésemos un estudio detallado de este poeta podríamos ir señalando y ejemplificando muchos de los rasgos que hemos enunciado como distintivos de la estructura de la lírica moderna, pero nos limitamos por ahora a esta visión rápida y parcial. Hay en estos poemas algunas desigualdades, pero decimos con Dámaso Alonso: "...cuánta juventud, cuánta alegría creadora y cuánta emoción en estos versos" 9 .

JUAN LARREA (1895)

Colaboró en las revistas ultraístas. No ha recopilado sus poemas en un libro. Al menos no tenemos noticias de que la publicación de su prometido Oscuro dominio, o de la Antología de que nos habla Gerardo Diego ${ }^{10}$, sea una realidad. Su obra está dispersa en revistas y en algunas antologías de poesía contemporánea.

El "creacionismo" - nos comenta personalmente Gerardo Diego- sirvió a Larrea para orientarse dentro de la "no dirección" del Ultra. Sin embargo su etapa creacionista se advierte menos por su gran personalidad. Hay en sus poemas más "larreísmo" que creacionismo.

En las primeras poesías de este autor hay con frecuencia imágenes creacionistas :

$$
\begin{aligned}
& \text { Un fotógrafo furtivo } \\
& \text { en el morral bien plegados } \\
& \text { se lleva los paisajes malheridos. }
\end{aligned}
$$

("Diluvio", en Grecia, núm. 29, 1919, pág. 16)

9 Op. cit., pág. 248.

10 Poesía española contemporánea. Antologia, 1901-1934. Madrid, 1959, páginas 374 y sigs. 
$\mathrm{O}$, tras el anterior acierto, este fragmento con imágenes más amaneradas y previstas:

\author{
La noche ha abierto sus paraguas \\ Llueve \\ Los pájaros de la lluvia \\ picotean los trigos de los charcos \\ Los árboles duermen \\ sobre una pata \\ Revoloteos, revoloteos.
}

("Nocturnos", en Grecia, núm. 28, 1919, pág. 2)

Pero incluso en la poesía más temprana de Juan Larrea, publicada en Grecia o Cervantes, ya se intenta expresar un mundo subconsciente, es alucinada o sonámbula, los temas se suceden fantásticamente. Podemos aplicar a las imágenes de Larrea, esta definición de la imagen surrealista :

...Surge naturalmente transida de oscuras significaciones, arrastra el peso de sus orígenes insondables, y su intensidad es más humana que estética. La imagen en el creacionismo es gratuita, abierta al juego y juego estético ella misma... En el surrealismo, por el contrario, la imagen es expresión concreta, comprometida y honda y por ello incomprensible, indescifrable, si se la pretende cazar con antenas lógicas; accesible sólo a una sensibilidad dispuesta a la comunión, capaz de abrirse a su contacto mágico, tenebroso, contacto o contagio ${ }^{11}$.

\title{
Asi, hondas y comprometidas, son las imágenes de "Di- luvio":
}

11 JosÉ ALBi - JoAn Fuster, Antología del surrealismo español, Alicante, 1952. página 182. 
YO que ayudé a bien morir las olas en tu nuca

$y$ descorché volcanes sobre los días expósitos

postulo ahora

un póstumo calor de los ahorcados

que cuelgan en mi vida

como frutos afónicos

es ya tarde

y aín no suena la diana de sus cuernos

el arco iris

en su concha guarecido

Sin embargo

el diluvio termina en este instante

Todos los hombres se han ahogado

Sobre los lechos flotan los cadáveres ${ }^{12}$.

En este largo "Ccsmopolitano" 13 se suceden sonambúlicamente las imágenes que la ciudad sugiere:

Mil agostos te he visto, frutecida

Ciudad.

Ciudad de hojas caducas

como mujer en rística

$y$ he cedido tu acera a la luna descalza

cuando con una brizna

$$
\text { un reflectcr discolo }
$$

la sacó de la cueva núbil y expatriada.

Mis alas se otoñaron hace tiempo.

12 En Grecia, núm. 39, 1919, págs. 16 y sigs.

13 "Cosmopolitano" tiene semejanzas con "Ecuatorial" poema cósmico de Vicente Huidobro. También Guillermo de Torre publicó un poema parecido: "Circuito", en Hélices. 
Pero aún hay charcos de mis ojos

$y$ un poco de mi voz entre los álamos.

Ciudad, bajo la niebla

te contemplo

a través del aire esmerilado.

De las nieves perpetuas

con un astro explosivo en la pechera

en sus skis urbanos

bajaban patinando los tranvias,

$y$ en las álgidas torres,

mejor que las campanas

la moza ordeñadora.

vendimió el amanecer de las majadas.

Cuántas veces el alba,

cuántas veces

deshojó pensativa las estrellas silvestres.

Hay un licor en cada cáliz

$y$ para los años frescos

cuántas veces también

la madre moribunda los pañales

tendia entre las calles

junto al portal de Belén.

Colegialas jóvenes

en las plazas abiertas,

jugaban a las cuatro esquinas

con las cuatro estaciones.

Dejadme revivir aquella primavera.

Un astro popular portado en hombros

legó el traje de luces al gentio;

desde los balcones oficiales

paseaban bellos peces flameantes

$y$ sobre los escotes

barridos por las olas

a las brisas de abanicos hímedos, 
rizaban el rizo

cormoranes y gaviotas.

Frotándonos

pasan las horas sonando el claxon

con un poco de humo que nunca fue mujer

sobre almohadones rojos

$y$ los tranvias la cayada al hombro

arrastraban rielantes

las cintas de las sandalias.

Al poniente los parques pleamares

las olas gateaban a los árboles.

En un roble vetusto crió por vez primera

gorriones disipados,

voceaban la prensa mañanera.

Sirenas exaltadas mejor que plumas fuentes

peinadas hacia atrás las chimeneas

cantaban entre dientes.

Descalzas en el río

$$
\text { cascadas catecúmenas }
$$

lavaban entonadas nuestras túnicas.

$Y$ es más

$$
\text { Porque hoy he visto }
$$

la gente enloquecida en el Hipódromo

aclamando al puente de Toledo

que ha batido a los jockeys más famosos.

En todas las fachadas

$$
\text { he dejado recuerdos tardos. }
$$

A lo lejos, entre estrellas ahorcadas,

la primera verbena

rueda por el horizonte fracasado.

Al asador un vals se asaba a fuego lento.

Los hombres giratorios

tocaban gravemente la guitarra.

Esta rosa boreal se pavonea 
$y$ el buen $y$ el mal ladrón crucificados

han jugado y perdido a la ruleta

el ancla de un reloj y un brazo.

Pero entre el frú-frí de instantes secos

$y$ de sombras pisadas

ni uno sólo de esos débiles mástiles

se tiende hacia la luna náufraga.

Despidámonos de aquella primavera

que hasta hizo florecer la vara del alcalde.

Al verla arriar

humedecimos las calles.

Del desierto lejano,

en coches de turismo,

vinieron trepidantes los estíos.

Mis versos, ya plumados,

aprendieron a volar por los tejados,

y uno solo, que fue más atrevido,

una tarde no volvió a su nido.

Luego,

sobre los montes guardainfantes,

a cielo traviesa,

miércoles de ceniza trashumantes.

Al salir del music-hall,

los vientos matutinos,

volvian a sus casas silbando una canción,

$y$ en todas las esquinas,

este otoño,

rotativas nómadas,

repartian proclamas clandestinas.

Las estrellas no cantan porque están de muda.

Sobre el viento

vilanos y plumas,

Las casas, quilla al sol,

a la deriva, 
como viejas tortugas malheridas

bajo la linea de flotación.

En mi dedo anular

triscaba aquella noche la estrella polar.

Una tarde Dios alzó el vuelo en el calvario.

Desde entonces los hombres le buscan en vano,

$y$ aquellos que pasaban

llorando, sin saber por qué lloraban,

al ver cómo partían los steamers,

eran YYYYYYYYYYYYY con los brazos cortos

$e$ iiiiiiiiii bajo estrellas graves.

Sin embargo,

penetraban los hombres en los templos

para todos los idolos.

Creyentes de rodillas,

regaban con ungüentos los pies advenedizos.

Todos los hombres se creyeron dioses

y a la vida tomaron con el calzado

limpio.

La noche está cerrada con cerrojos.

Una llave de oro.

No es una orejilla de mujer la cerradura.

Pero es lo mismo.

La clausura

como mujer se abre.

Peceras fínebres

iluminan las calles.

El cielo está tan bajo

Los puntos cardinales

que mi cabeza se ha abollado.

en hombros conducian

A lo largo de la vida

un ataúd vacio. 
pasaban los cipreses.

No es el mio.

Los faroles se relevan de hora en hora.

Por el suelo disputaban

las aves y los charcos

Y los turbios espejos

nuestras lágrimas.

arrojan nuestra imagen

a los mares enjaulados allá

Mejor que yo lo sabes.

lejos.

Media noche.

Temblaban los relojes.

En mi cuarto

un buey embalsamado

se espantaba las horas con el rabo.

La resaca nos bandea mejor que a un secafirmas

y la hoguera a cuyo albor cantamos

perdió su benjamin entre los dias.

Esta calle postrera

$$
\text { nos conduce al Museo. }
$$

La vida disecada entre desnudos fósiles

y esta rada perenne entre la vida.

Aquellos que murieron contemplan desde fuera.

$Y$ los siglos lejanos

están en las ventanas agolpados.

Museo de escultura.

Infierno de canibales $y$ viudas.

Palomas cenitales

abanican la eternidad dormida.

Robáranme la vida.

Aquel pedestal vacio.

NO

no es tampoco el mío.

Pero es el de mi amada ${ }^{14}$.

14 En Cervantes, nov. 1919, págs. 23 a 28. 
Guillermo de Torre consagró a la empresa ultraista todas las energías de su adolescencia. Fue "el novio oficial de mademoiselle DADÁ" 15 , el ferviente enamorado de "la fémina porvenirista" ${ }^{16}$. Con anterioridad a la constitución del grupo ultraista sentía la inquietud de "lo nuevo" y el ultraísmo le brindó el ambiente de modernidad que buscaba. Dentro del movimiento desarrolló una gran actividad: fue "el secretario de relaciones exteriores", mantuvo correspondencia con los escritores vanguardistas extranjeros, tradujo sus poesías y las publicó, acompañadas de comentarios, en las revistas ultraístas. Su conocimiento de todas las estéticas de vanguardia vigentes en Europa se refleja en el "Manifiesto Vertical", que quiso ser la' exposición del credo ultraísta.

Guillermo de Torre fue publicando en las revistas sus artículos críticos y teóricos, la mayoría de los cuales fueron incluidos en su Literaturas etrropeas de vanguardia (1925), historia minuciosa del ultraísmo y de los restantes "ismos" europeos. Hoy ha modificado algunas de las posiciones y afirmaciones hechas en su juventud ${ }^{17}$ y ha calificado al estilo de Literaturas europeas de vanguardia de "excesivo, de vocabulario neológico" ${ }^{18}$. Hay, en efecto, cierta parcialidad propia de quien se ha sentado a escribir en pleno campo de batalla, pero

15 Así se llamó humorísticamente él mismo en un "Album de Retratos" aparecido en Grecia. Citado por J. de la Escosura: "Guillermo de Torre", en Cervantes, oct. 1920, pág. 88.

16 Cf. "Madrigal aéreo", en Hélices, 1923, pág. 77.

17 Cf. sus obras: Guillaume Apollinaire. Su vida, su obra, las teorias del cubismo (Bs. As., 1946) y Problemática de la Literatura (Bs. As., 1951).

18 En Problemática..., pág. 188. 
es esta obra un documento indispensable para quien quiera conocer esa confusa etapa de la literatura del siglo $\mathrm{xx}$.

La gran importancia de Guillermo de Torre dentro del ultraismo reside precisamente en su papel de inductor, de definidor, de historiador y en haber sido el principal nexo entre España y el extranjero. En cambio sus poesías aportaron poco al ultraísmo, a pesar de que dio uno de los pocos libros con que cuenta el movimiento: Hélices.

Como colofón de la obra leemos lo siguiente:

HÉLICEs, libro de poemas varios, disímiles y afines, que recoge las diferentes etapas evolutivas, franqueadas por el poeta, en el orto de su devenir ascensorial, fue compuesto de MCMXVIII a MCMXXII inclusive, años paralelos de su adolescencia inquieta y de su espíritu solicitado por múltiples experimentos $y$ avideces innovadoras.

En este libro recopila los poemas dispersos en revistas y añade otros inéditos.

Abundancia de neologismos y de términos científicos, carencia de puntuación, extraña disposición tipográfica, rasgos de la modernidad esquemáticamente enunciados, desfile de "imágenes cinemáticas", son características de estos poemas. Hay en ellos un vanguardismo cerebralmente buscado, un deseo de asimilar todos los "ismos" programáticamente. Ciudades multánimes y tentaculares, trepidaciones maquinísticas, acordes aviónicos, vibraciones convulsivas, vértigos dinámicos, son elementos de su canto "hipervitalista".

Podemos distinguir en el libro una faz barroca y una faz creacionista.

"Paisaje plástico", con tipografía expresiva, nos describe un ardiente mediodía. (Véase aquí el grabado n. ${ }^{\circ} 7$.) 
Los "Hai-kai", agrupados en la última parte del libro, presentan una tercera faz, más sentimental, aunque sigue predominando la imagen :

Otro árbol, con las manos

en los bolsillos, se ciñe

los collares del viento.

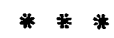

La tijera del viento

corta las cabelleras

de las espigas más esbeltas.

Su cuerpo tan ingenuo

se deslie entre las olas.

$Y$ el mar rebosa de azules.

Un árbol oblicuo sacude

mareado sus melenas, - hojns

amarillas del otoño.

***

Mi corazón adelanta la hora:

Si no acudes me clavaré la espada

del recuerdo: harakiri.

Adios, japonesismos de Occidente,

escritos $\sin$ grafía vertical

$y$ para ojos sin oblicuidad! 
JORGE LUIS BORGES

Borges nos dice de sí mismo:

Soy porteño: he nacido el mil novecientos en la parroquia de San Nicolás, la más antigua de la capital, al menos para mí. La época de la guerra la pasé en Ginebra, época sin salida, apretada, hecha de garúas y que recordaré siempre con algún odio. El diez y ocho fui a España. Allí colaboré en los comienzos del ultraísmo. El veintinuo regresé a la patria... ${ }^{19}$.

El paso de Borges por España y su participación en el ultraísmo español fue decisivo para la ulterior orientación de la poesía argentina. Cansinos-Asséns nos habla de esta etapa:

...Jorge Luis Borges... pasó por entre nosotros como un nuevo Grimm, lleno de serenidad discreta y sonriente. Fino, acuánime, con ardor de poeta sofrenado por una venturosa frigidez intelectual, con una cultura clásica de filósofos griegos y trovadores orientales que le aficionaba al pasado, haciéndole amar calepinos e infolios, sin menoscabo de las modernas maravillas, Jorge Luis Borges observaba, discutía cortésmente con sus camaradas juveniles y tomaba de la nueva lírica, llegada a nosotros en los libros de Huidobro, que por entonces estaban perennemente abiertos sobre los facistoles, la nueva lección de fuga y contrapunto con que al través de las edades se van remozando los eternos temas ${ }^{20}$.

19 "Algunas páginas de la Exposición de la actual poesía argentina, por P. J. Vignale y César Tiempo", en Martín Fierro, núm. 39, Bs. As., 28 mar20 de 1927.

20 Cansinos-Asséns, Rafael, la nueva lit., págs. 280-28 . 
Borges recuerda aquellos tiempos juveniles: "Junto a Don Rafael Cansinos-Asséns polemicé, publiqué traducciones de los nuevos poetas alemanes, metaforicé con fervor" ${ }^{21}$.

Sus primeros tanteos poéticos se encuentran dispersos en Grecia, Ultra, Cervantes, Horizonte, Tableros y alguna otra revista. Su autor, años más tarde, renegó de ellos, se arrepintió de haber elaborado "áridos poemas de la secta, de la equivocación ultraísta" 22. Pero, como dice Cansinos-Asséns, Borges "gustó sin marearse del mosto nuevo" ${ }^{2 b}$. Fundió las novedades con los anuncios de un estilo propio. Hay con frecuencia en estos poemas emoción, aunque contenida por la reflexión. Casi todos ellos tienen cierta unidad, sentido constructivo, no son meros collares de imágenes. Él mismo nos dice en el prólogo de Fervor de Buenos Aires: "Siempre fui novelero de metáforas, pero solicitando fuese notorio en ellas antes lo eficaz que lo insólito".

Guillermo de Torre nos habla de las influencias vanguardistas europeas que pesaron sobre el joven Borges: "Llegaba ebrio de Whitman pertrechado de Stirner, secuente de Romain Rolland, habiendo visto de cerca el impulso de los expresionistas germánicos, especialmente de Ludwig Rubiner y de Wilhelm Klemm" ${ }^{24}$.

Cansinos-Asséns en el trozo transcrito nos habla de la influencia huidobriana.

Pero incluso en estos comienzos literarios europeos y a pesar de su formación en Suiza, Borges refleja su raíz argentina. Ya en los poemas publicados en España se desliza a cada momento

21 Citado por JUAN PINTO: Breviario de literatura argentina contempordnea, Buenos Aires, 1958, pág. 20 y en Antologia de la poesia argentina moderna, Buenos Aires, I931.

22 Citado por ANDERSON-IMBERT, E., en Historia de la literatura hispanoamericana, México, 1954, pág. 382.

23 Op. cit., pág. 281 .

24 Literaturas..., pág. 62. 
la presencia de la patria en un término o en una imagen. Unas veces se trata de un argentinismo:

Las bayonetas sueñan con los entreveros nupciales. ("Trinchera", en Grecia, núm. XLIII, 1920)

Otras de un diminutivo afectivo:

La luna nueva fue una vocecita en la tarde

("Montaña", en Tableros, núm. 2, 1921)

O de imágenes que sugieren el recuerdo de la pampa argentina, del gaucho y su guitarra, de las amarillas parvas que cortan la infinita horizontalidad del paisaje, del caballo criollo...

el sol con sus espuelas desgarra los espejos

("Mañana", en Ultra, núm. 1, 1921)

La caravana lanza un ebrio lazo

$y$ en el prado relinchan los luceros.

("Distancia", en Ultra, núm. 9, 1921)

La catedral que es una parva

con espigas de rezo.

("Catedral", en Ultra, núm. 19, 1921)

En el capitulo sobre el expresionismo hablamos ya de las poesías de Borges con temas de la guerra europea. He aquí otras poesías de distinto tema:

eL ULTRAISMIO. - 10 


\section{SINGLADURA}

A Rivas Panedas.

He pulsado el violin de un horizonte

brocal del mundo donde el Sol se macera

El viento esculpe oleaje

La neblina sosiega los ponientes

La noche rueda como un pájaro herido

En mis manos

el mar

viene a apagarse

el mar catedralicio

que iba empotrando agujas $y$ vitrales

La media luna se ha enroscado a un mástil 25.

En "Aldea", que apareció en el núm. 2 I de Ultra y se incorporó a Fervor de Buenos Aires es mayor la vivencia de un sereno atardecer, que el alarde imaginífero:

El poniente de pie como un Arcángel

tiranizó el sendero

La soledad repleta como un sueño

se ha remansado al derredor del pueblo

Las esquilas recogen la tristeza

dispersa de las tardes

la luna nueva

es una vocecita bajo el cielo

Segin va anocheciendo

vuelve a ser campo el pueblo

Cuando Borges regresó a Buenos Aires fundó el ultraísmo argentino del cual se arrepintió más tarde. En 1923 publicó

25 Ultra, núm. 8, 20 de abril de $192 \overline{1}$. 
Fervor de Buenos Aires. Excluye de este libro sus primeros intentos ultraístas, salvo alguna rara excepción como la citada. El poeta se vuelve a sus Buenos Aires, no al cosmopolita y dinámico, sino a "la dulce calle de arrabal, estremecida de árboles y ocasos" ("Las calles"), desde donde la pampa se presiente ${ }^{26}$. Expresa además, partiendo de lo cotidiano, sus inquietudes metafísicas. Está ya muy lejos - aunque se proclama ultraísta y utiliza con frecuencia recursos del movimientode los típicos poemas de Ultra: mero alarde de ingenio y tintineo sin melodía unitaria.

Años más tarde, en su "Arte poética", dirá :

Cuentan que Ulises, harto de prodigios

Lloró de amor al divisar su Itaca

Verde y humilde. El urte es esa Itaca.

De verde eternidad, no de prodigios ${ }^{27}$.

PEDRO GARFIAS

Fue uno de los exploradores ultraístas. En su libro El ala del sur (1926) recoge poemas que reflejan la línea del ultraísmo, desde su nacimiento a su fin. Es el libro que Guillermo de Torre anunciaba con el título de Ritmos cóncavos ${ }^{28}$. El nombre de la obra alude a Andalucía ("Mi corazón temblando bajo el ala del Sur", dice en la primera página).

Guillermo de Torre caracteriza así a este poeta: "procedente... de la zona romántica, y bajo la égida de los soles meri-

26 Hoy Borges confiesa nuevos arrepentimientos. En su Antologia personal (Buenos Aires, Sur, 196r), por la cual quiere ser juzgado, no incluye - nos dice- "determinados ejercicios de excesivo y apócrifo color local que andan por las antologías y que no puedo recordar sin rubor".

27 "Arte poética", en El hacedor, Buenos Aires, 1960, pág. 101.

28 Cf. Literaturas..., pág. 8I. 
dionales, los plenilunios colmados y los campanarios revoleantes, obtiene visiones imaginiferas de sorprendente relieve" ${ }^{29}$.

Los comienzos de Garfias fueron modernistas pero se unió :al ultraísmo desde su primera hora (fue uno de los firmantes - del manifiesto). Hay en sus poesías influencia de Huidobro. : aunque ésta no es exclusiva. En algunas predomina la búsqueida de la imagen, en otras se desliza la nota sentimental. Es frecuente el tema del tiempo, de las horas del día (el alba, el crepúsculo, la noche), de los campanarios. No puntúa sus poesías.

Veamos algunos ejemplos:

\section{SOL}

Las ramas se han colgado sus pendientes

Y el Sol

el Sol

el Sol

ha tendido sus redes

Mi corazón es un pez rojo entre las mallas

¡Abrid!

abrid mi jaula

Catarata policroma

Alguien vierte su vida

sobre todas las llagas

¿Ganará mi esperanza?

Y los copos del Sol

resbalan por mis ojos

vacios 30

29 lbidem, pág. 71.

30 En Grecia, núm. 25, 1919, pág. 8. 


\section{$A \cup N$}

Los pájaros se tiran serpentinas

azules como arroyos

$y$ todas las campanas

corren por los tejados persiguiéndose

Clavada en lo más alto ondea

mi esperanza ${ }^{31}$

$O$ este fragmento sentimental:

\section{DISTANCIA}

Se han quebrado nuestras miradas

Tan lejos

Tiemblan mis sueños

porque han perdido su jaula

$y$ mis palabras su sendero

Pero mañana

llorará el sol cenizas sobre mi frente

y el viento habrá olvidado tu nombre

yo colgaré mis ojos de otra estrella ${ }^{32}$

También está presente en Garfias el aspecto humorístico y la alusión a las modernas máquinas :

El avión

extraviado, se coló en la sala

$y$ conoció su error

al dar en las columnas con las alas.

Intervino el acomodador ${ }^{33}$.

31 En Ultra, núm. 1, 27 enero, 1921.

32 En Cervantes, junio, 1920, pág. 25.

33 "Cinematógrafo", en Grecria, núm. 17, 1919, pág. 6. 
ADRIANO DEL VALLE

Era modernista. Su "ultraísmo" se reflejó, sobre todo, en una mayor libertad de formas. Publicó, sin embargo, poesías declaradamente "ultraístas", con abundancia de imágenes y extraña tipografía. Guillermo de Torre lamenta que la habilidad ambidextra de Adriano del Valle no le deje entregarse unilateralmente a las nuevas estructuras ${ }^{34}$. La temática es casi la misma para ambos tipos de poesía: el mar, los astros, reyes bárbaros, personajes orientales o exóticos, el mundo helénico. la amada...

\section{NAUFRAGIO}

'Siglo

milenio

instante

cuántos después $y$ antes

Cuántos barcos y lunas cruzaror to distante del mar

Mar

Mar de palabra clave

Mar de mirada grave

que al viento das la cara

$y$,el hombro blando al ave

Siglo

milenio

instante

Tú y yo

los dos

asidos

a dos

interrogantes ${ }^{35}$.

34 Literaturas..., pág. 74 .

35 Ultra, núm. 3, 1921. 
Incluso sus ensayos imaginíferos reflejan un mundo sereno, no llegó a las estridencias de otros ultraístas. La presencia de un elemento del mundo clásico ("cantaba un sistro / cautivo en la garganta de una alondra") ${ }^{36} 0$, como en esta "Alba lluviosa", las brumas, la lluvia, el adjetivo "rosado", el paisaje semejante a "un fondo" marino, suavizan la actitud provocativa con que se presentan, por lo general, las imágenes del ultraísmo :

\section{ALBA LLUVIOSA}

La luna

se ha puesto una escafandra de bruma

$y$ el paisaje

parece un fondo marino

Hay una red de estrellas

medio rota

que caza pájaros de sol

$$
\text { El sol navega }
$$

entre arrecifes de coral...

¿En qué mástil rosado

va mi alma enganchada por un ala?

Llueve...

El paisaje tiene el corazón mojado... ${ }^{37}$.

EUGENIO MONTES

Cuando comenzó a frecuentar la tertulia de Cansinos-Asséns, ya había leído a Apollinaire. Fue de los primeros en prac-

36 De "Cantos de Hiperionda", Grecia, núm. XXXVII, 1919.

37 Girecia, núm. XXXVII, 1919. pág. 7 . 
ticar la nueva poesía. Gerardo Diego le dedica un poema ("Creacionismo"): "A mi Virgilio, Eugenio Montes". Los rasgos de su poesía ultraísta son los que ya hemos señalado en otros poetas (imagen múltiple, desjerarquización del arte, etcétera):

Las nubes son pompas de jabón.

La lusna envía a Júpiter una cita en un

mensaje telegráfico.

("La Luna") $)^{38}$

\section{PUEBLO}

Las casas como reclutas

y las campanas

lloviendo saludos.

El espacio es una bandera gris

Sobre el reloj tiemblan

alas de pájaro.

El Sol

extrae de cada piedra

el corazón

En el café los domingos me agujetean con sus ojos como a un flalletero.

El pueblo detenido en su vuelo de noche es una sonrisa ${ }^{39}$.

Por sus "Poemáticas Esquematizaciones Fantasistas" desfilan irónicas visiones de la vida moderna y sensaciones urbanas... Por ejemplo en ésta :

38 En Grecia, núm. XXIV, 1919, pág. 7.

39 En Grecia, núm. XLII, pág. 12. 


\section{ATARDECER EN NEW YORK}

A Vicentc Risco.

El crepúsculo barnizado de whisky - es ahogado por olas blancas. - Los rascacielos, arrodillados, elevan - plegarias a las nubes. - El sol está detenido en un vaso - en la mesa de la terraza de un bar. - Las nubes arrojaron del dedo los anillos. - Ventiladores nómadas. - La multitud es una llama que el viento riza, - presa en el túnel de la avenida. Los automóviles nadan a impulsos cortos. - Distendidos los brazos $y$ en el pecho un fatigoso jadear. - Treinta gamas de grises cayeron de una paleta, - quemaron las alas y regaron los objetos. - Enmudecieron las cigarras que solfean en los trolley. - Cajas musicales. - Las trompas esquivadas dicen: - DO RE FA. - Se nota la ausencia de la batuta del director de orquesta. - Un pintor va dando pinceladas amarillas en los gasómetros. - ¿Dónde está la concha del apuntador? - DO RE FA. - Tocan sólo los instrumentos de metal. - Los violines esperan tres compases. - Ante la indiferencia de los espectadores, las trompas epilépticas insisten : - DO RE FA ${ }^{40}$.

En su poesía hay cierta emoción y delicadeza. En él, nos dice Guillermo de Torre "descuella un espíritu fundamentalmente romántico - romanticismo íntimo de visión y sentimiento, mas no por la estructura- que en ocasiones trata vanamente de enmascararse con temas distintos" ${ }^{41}$. No sabemos si se publicó su libro Cruces, que anuncia Guillermo de Torre.

40 En Grecia, núm. XVI, pág. 12.

41 Literaturas.... pág. 69. 


\section{LE J O S}

Lejos

Lejos

Cómo se me revela ahora nunca oido este sonido

Lejos

Lejos

Al producirlo apago las estrellas

(Que ya es toda una noche decir:

lejos).

Al producirlo apago las estrellas

$y$ parece que lo acaricio entre los dedos

ahora que he andado por los caminos del tiempo

Lejos

Lejos

Cómo me rompe la dulzura del mundo

asi tras un cristal nítido jay pero seco!

ahora este sonido

Lejos

Al producirlo apago las estrellas

$y$ parece que lo acaricio con los dedos

ahora que he andado por los caminos del tiempo ${ }^{42}$.

\section{EL POZO}

El pozo de las noches

para las canciones extraviadas

y la ancha proa del viento

y mi corazón arbustillo quieto

42 En Ultra, núm. 24, 9922. 
No me habia enterado

me cayó de los brazos

$$
\text { y la vida }
$$

dormida

Qué alegre el doble cielo

(Cielo y tierra)

Te quiero

Te quiero

$Y$ del campanario

los tañidos

bajaron

a beber el silencio de sus manos ${ }^{43}$.

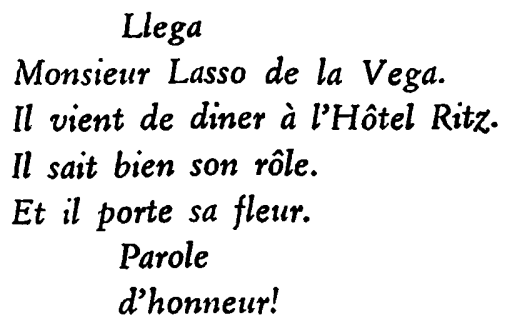

(de "Tertulia", de P. Vighi)

Sus intentos ultraistas son esporádicos. Cuando comenzó a colaborar en las revistas del movimiento, había ya cumplido una trayectoria poética bastante larga. En 1910 publicó Rimas de silencio y soledad, dedicado " la divina memoria de Gustavo Adolfo Bécquer": en 1919, El corazón iluminado, con influencia de Rubén Darío y de las escuelas francesas del si-

43 Ultra, núm. 21, 1922. 
glo xIX y Galérie de Glaces, en versos libres ${ }^{44}$. A partir de IgI9 envía a las revistas del Ultra composiciones decididamente vanguardistas y llega a los extremos de DADÁ. Muchos de sus poemas son "autoversiones del francés":

\section{POEMAS AUTOMÁTICOS \\ (POĖMES AUTOMATIQUES) \\ JORNADA}

Avis serrure de sûreté lettre

recommandée

Aviso cerradura de seguridad certificado

ayuda de cámara propinas desayuno

salón de fumar grill room brasserie

pasillo centrifugo cuartos de baño

distribuidor general de las energias calculadas

carruaje radiograma bolsa de cambio

sleeping car oficina de correos all revoir ${ }^{45}$.

En "Cabaret" desarrolla un tema que es frecuente en el ultraísmo :

Souper tango folie Flambeaux étincelles

Aube de la nuit Nus Danse des étoiles

Champagne Whisky and soda guirlandes tulipes

Jet d'eau jeux de glaces Jour artificiel

Souper-tango locura antorcha centelleos

Alba de la noche Desnudos Danzan de las estrellas

Champagne Whisky and soda Guirnaldas tulipas

Surtidor juegos de espejos Día artificial

44 En Grecia se anunció la publicación de este libro y se reprodujeron algunos poemas. No sabemos con seguridad si esta publicación se llevó a cabo. 45 Ultra, núm. 2, 1921. 
Nace la espuma delirante de los colores

Enlace de miradas Capricho de amor mariposa

Máquina ligera viviente de atractivos que llaman

Todo esto es un barco Fábrica de placeres

Se desliga danzando por un rio floreciente

Es linda la mujer Pantera tórtola

Despliega el abanico de sonrisas

A los sones de las orquestas Ráfagas Canciones

Oleada que gira bulliciosa Carrusel

Tziganes rojos jazz-band Cascabel torbellino

Músicas acrobáticas de los negros jocosos

para cocotas resplandecientes de joyas $y$ de encajes

que tangotean entre los brazos de gentiles amadores ${ }^{46}$.

ISAAC DEL VANDO-VILLAR

Andaluz. Fue el director de Grecia y de Tableros. Procede de la generación rubeniana, pero, nos dice Guillermo de Torre, "lleno de voluntad intenta vencer las reminiscencias de aquella época para asimilarse a la manera ultraica" 47.

Recopiló muchos de sus poemas en un libro: La sombrilla japonesa (1924). Casi todos ellos están escritos en una época de transformación artística: "Hai-kais", "Poemas de América", "Cohetes", "Reyes de Oriente", "Carrousselles"...

En "Columpios" -que tiene alguna semejanza con el "Tío-Vivo" de García Lorca- el poeta da a una niña dimensiones cósmicas y logra un cuadro lleno de frescura :

La niña alargaba sus pies

para tocar con ellos las estrellas,

pero su cabecita se encogía

para no tropezar con el arco iris.

46 Grecia, núm. 37, 1919, pág. 6.

47 Literaturas..., pág. 72. 
¿Hay un momento en que la niña

se ha detenido en el espacio

para besar a Venus!

¿Qué mano misteriosa bambolea

los columpios colgantes de los niños?

Allá lejos, la tarde, se está vistiendo de etiqueta

para el gran cotillón de la noche ${ }^{48}$.

Compárese con la poesía de Lorca:

\section{TIO.VIVO}

Los dias de fiesta

van sobre ruedas.

El tío-vivo los trae,

$y$ los lleva.

Corpus azul.

Blanca nochebuena.

Los días abandonan

su piel, como las culebras,

con la sola excepción

de los dias de fiesta.

Estos son los mismos

de nuestras madres viejas.

Sus tardes son largas colas

de moaré y lentejuelas.

Corpus azul.

Blanca nochebuena.

48 Grecia, núm. XXXIX, I920, pág. I4. 
El tío-vivo gira

colgado de una estrella.

Tulipán de las cinco

partes de la tierra.

Sobre caballitos

disfrazados de panteras

los niños se comen la luna

como si fuera una cereza.

¡Rabia, rabia, Marco Polo!

Sobre una fantástica rueda,

los niños ven lontananzas

desconocidas de la tierra.

Corpus azul.

Blanca nochebuena ${ }^{49}$.

Xavier Bóveda. - Poeta gallego, gozaba, antes de incorporarse al ultraísmo, de alguna fama literaria. Había publicado un libro: Epistolario romántico y espiritual. Rosario lírico $y$ otros poemas (Orense, 1917). En 19.18 escribía en El Parlamentario y fue la entrevista a Cansinos-Asséns allí publicada el acontecimiento que señaló el nacimiento oficial del ultraísmo. Los nuevos entusiasmos le inspiraron algún poema al tranvía o al automóvil, pero pronto lamentó el abandono del estilo y de los temas regionales que le habían proporcionado cierto renombre y "se apeó resueltamente del tranvía ultraico" ${ }^{50}$, pàra dedicarse a cantar a los pinos de Galicia.

49 En Canciones (1921-1924).

50 Cansinos-Asséns, Rafael, "Para los Poemas de los pinos, de Xavier Bóveda". En Grecia, núm. XXV, 19rg, pág. Ir. 
José de Ciria y Escalante. - Fue creacionista. Murió en 1924, a los veinte años. Un grupo de amigos, e.tre ellos Gerardo Diego, por inspiración de Melchor Fernándt : Alınag. recopiló su escasa obra bajo el título de Poemas.

César A. Comet. - Fue ultraísta de la primeta hora: "no de los firmantes del manifiesto. Cultivó la imagen, pero, nos dice Guillermo de Torre: "rehuyendo las claras plasmaciones metafóricas, se intrinca en conceptuosos dédalos verbales y forja abstractos símbolos" 51. Publicó Bellezas grotescas (¿1933?).

Eliodoro Puche. - Murciano. Según explica González-Ruano, escribió su nombre sin la hache por una fidelidad al recuerdo de su madre, "mujer sencilla y antiortográfica que le escribía Eliodoro en los sobres de sus cartas" ${ }^{52}$. Vemos más bien el afán de singularizarse, propio del individualismo de la época. (También Xavier Bóveda cambió por equis la jota de su nombre). González-Ruano, nos dice además que Puche, por su vida bohemia, "fue una especie de Gerardo Nerval en traducción humana económica. Fue tertuliano de los rivales Cansinos-Asséns y Ramón Gómez de la Serna, y vivió heroicamente, en una prodigiosa pobreza, las madrugadas vacilantes de todas las noches de su vida" ${ }^{33}$. Había publicado dos libros modernistas: El libro de los elogios galantes y de los crepuisculos otoñales y El corazón de la noche (sin fecha). En Cervantes (marzo 1919. págs. 143-144) encontramos un comentario de Guillermo de Torre al libro de Puche Motivos liricos (1919), en cuyas últimas páginas se observa la influencia de Huidobro. También se observa esta influencia en los poemas publicados en las revistas de Ultra.

31 Literaturas..., pág. 76.

52 González-Ruano, César. Antologia de poetas españoles contemporáneos en la lengua castellana, Barcelona, 1946, pág. 205.

53 Ibidem, pág. 205. 
Humberto Rivas. - "Piloteó" la revista Ultra. Se incorporó tardíamente al ultraísmo; era hermano de José Rivas $\mathrm{Pa}$ nedas. Se ejercitó, como casi todos- en buscar imágenes.

Lucia Sánchez Saornil. - Colaboró mucho en las revistas del movimiento con el seúdónimo "Luciano de San-Saor". Se inició bajo la influencia de los post-modernistas, pero saludó al ultraísmo con alborozo y se incorporó a él :

\section{EL CANTO NUEVO}

¡Oh, cuánto tiempo Hora $N$ uestra

te hemos esperado!, ¡cuánto!

${ }_{i} \mathrm{Oh}$, cuántas veces tendimos

el cable de nuestra mirada limpia al futuro

$Y$ aplicamos el oído extático

al viento,

ávidos de distinguir

tu música en embrión!

$Y$ al fin te poseemos

Hora Nuestra;

El horizonte es la pauta, hermanos ${ }^{54}$.

Rafael Cansinos-Asséns. - Hemos dicho ya que su papel de "faro" en el movimiento ultraísta, y en los cambios fundamentales que éste introdujo en la lírica española, se deben, no a la influencia directa de su obra, de su estilo (que nada tenía de ultraísta), sino a su influencia personal. Con todo, hizo algunos ensayos imaginíferos bajo el seudónimo de "Juan Las".

Jizan Chabás y Martí. - Simpatizó con el ultraísmo, según se refleja en su labor crítica. Colaboró en la revista Ultra. En

54 Grecia, núm. XLIII, págs. 49-50.

BL ULTRAISMO. - II 
I92 I publicó un libro de poemas: Espejos, en el que se combinan influencias ultraístas y juanramonianas. El 4 de enero de I923 dio en el Ateneo de Madrid una conferencia sobre: "La última actitud lírica".

Rogelio Buendia. - Nació en Huelva. Colaboró en casi todas las revistas de vanguardia. En 1923 publicó La rueda de color, de caracteres ultraístas, que marca un momento de su trayectoria poética. Publicó otras obras, antes y después de esta etapa $^{55}$.

Joaquin de la Escosura. - De él nos dice Guillermo de Torre: "muy inquieto y juvenil, sarpullido de intenciones criticistas, logra en sus poemas renovar sensaciones ingenuas o motivos románticos" 56 . Su poesía no tiene rasgos personales definidos; hay sí, clara influencia huidobriana.

Juan Gutiérrez-Gili. - (1894), catalán. Publicó un Primer Libro de Poemas (1918), post-modernista y en 1925, Surco y Estela, que incluye algunas poesías personales y otras que son sólo una colección de imágenes superpuestas. Colaboró en Ul. tra y en Tableros.

César González-Ruano. - (Igoẓ), Madrid. Publicó varios hbros juveniles, algunos de tendencia ultraísta, aunque no plenamente ortodoxos. Colaboró en la revista Ultra. En su libro de memorias $\mathrm{Mi}$ medio siglo se confiesa a medias (195I) nos habla de aquellos días, de las tertulias con Cansinos y de sus compañeros de aventura. En 1921, con el pretexto de hablar del ultraísmo, pero con la sola intención de llamar sobre sí la

55 El poema de mis sueños, Del bien y del mal, Nácares, Naufragio en tres cuerdas de guitarra, Diagramas del sueño. En la revista Fantasia, Madrid, 1945. núm. 10, aparecen poemas inéditos, con el título de "Vuelo y tierra".

56 Literaturas..., pág. 78. 
atención de la prensa y del público, apareció en el Ateneo de Madrid con su pelo súbitamente rubio y lanzó desde la tribuna tan audaces palabras que provocó un escándalo mayúsculo.

Pedro Raida. - Después de su "conversión" al Ultra, llena de luchas, colaboró con regularidad en Grecia y otras revistas. No tenía cualidades poéticas.

Publicó su libro ultraísta Mercedes (Sevilla, 1920).

Francisco Vighi. - (1890-196I). No fue ultraísta, pero tuvo relación con el movimiento. Publicó, en España y en las revistas de vanguardia, sus poesías, de original y sano humorismo. Nos dice Federico de Onís que Vighi no tomó al Ultra ni más ni menos en serio que otra cosa ${ }^{57}$.

Francisco y Guillermo Rello. - Ultra publicó los poemas que escribían en colaboración. Participaron en la velada de $\mathrm{Pa}$ risiana. Guillermo murió a los diecisiete años y Francisco se perdió en el olvido.

Antonio Espina. - (1894), Madrid. Aunque no participó del movimiento tuvo algunas aproximaciones. En España, La Pluma y otras revistas, publicó poemas que, por su extraña tipografía y afán renovador, se relacionan con los experimentos de vanguardia. Publicó Umbrales (1918) y Signario (1923).

Estuvieron también relacionados con Ultra: J. José Pérez Domenech, Joaquín Edwards (chileno, dadaísta), Prieto y Romero, Manuel de la Peña - autor de un librito sobre el ultraísmo y director de revistas del movimiento-. Eduardo de Ontañón, Antonio Cubero - que escribía complicadas prosas-. Jaime Ibarra, Jacobo Sureda, Juan González Olmedilla. Tomás

57 Op. cit., pág. 1053. 
Luque, Pedro Olmedo Zurita, Luis Mosquera, Ernesto LópezParra, Pedro Luis de Gálvez, Correa-Calderón, Fernando de' Lapi...

Mauricio Bacarisse, como hemos visto, tuvo una aproximación tangencial: simpatizó con el movimiento y fue su abogado defensor en la velada de Parisiana. 


\section{CONCLUSIÓN}

\section{BALANCE Y FIN DEL ULTRAISMO}

Guillermo de Torre nos habla de la disolución del grupo:

El Movimiento Ultraísta, como tal, como bloque colectivo, destinado a ejercer una acción conjunta y a mantener un estado de espíritu radical y renovador, pudo en realidad considerarse como disuelto al dejar de publicarse periódicamente Ultra en la primavera de 1922, y tras el primer golpe a la solidaridad sufrida un año antes, con ocasión de la segunda velada ultraista. Alli quedó patente la dificultad de prolongar la acción colectiva exterior, tanto por incompatibilidades de ciertos caracteres, como por la ausencia de un mínimo de disciplina necesaria. Por otra parte, el objetivo esencial : marcar una ruptura neta con la generación anterior, negarse a ser epígonos para asumir el gesto de hermes (que diriamos con la terminología cansiniana), habria quedado ya explícita y ampliamente lograda. ¿A qué, pues, prolongar innecesariamente la asociación ocasional y el gesto común que unificaba. en ciertos casos, espíritus disímiles? Tanto más cuanto que reiteradamente habíamos afirmado no componer una escuela unilateral, librándonos de contraer un compromiso solidario ${ }^{1}$.

1 Literaturas..., pág. 81. 
Guillermo Díaz-Plaja se refiere también al fin del ultraísmo con términos categóricos: movimiento "liquidado" hacia $1923^{2}$.

Los críticos e historiadores de la literatura han menospreciado en general el ultraísmo. Es evidente que del heterogéneo ejército ultraísta, se salvan sólo unos pocos poetas y algunos esporádicos aciertos.

La mayoría de los poemas, al carecer de un impulso constructor y conjuntivo, al presentarse como inorgánica suma de imágenes, son comparables a la música de un organillo, a un monótono tintineo. "Poetas de babador y sonajero", llamó Azorín a los ultraistas ${ }^{3}$. Ellos mismos vieron este peligro: Guillermo de Torre cita a Borges, quien previene contra la cacería de la "phrase à effet", y a Eugenio Montes: "Habíamos llegado a retorcernos en un verdadero empacho de imágenes y metáforas" ${ }^{4}$. La poesía convertida en juego de ingenio y de imaginación es flor artificial madurada fuera de la planta, algo "que se ha querido hacer".

Nos dice Dámaso Alonso que el fracaso del ultraísmo consistió en no querer usar de las adquisiciones de la poesía tradicional, y al mismo tiempo en no haberlas sabido sustituir: "No se improvisan las maestrías del verso: Ultra, no pudiendo dominar un ritmo nuevo, eludió todo ritmo y fue a abandonarse en las más plebeyas coplerías" 5 . Guillermo de Torre opina que a este motivo de fracaso se agrega el hecho de que los ultraístas se limitaron a la poesía, sin abordar otros géneros de mayor radio expresivo (como hicieron, por ejemplo, los expresionistas alemanes que cultivaron la novela y el teatro) ${ }^{6}$.

2 Historia de la poesia lírica española, Barcelona, 1948, pág. 394.

3 Citado por Chabás y Martí, en Alfar, núm. 36, 1924, pág. 19.

4 Literaturas..., pág. 299.

5 Estudios y ensayos gongorinos, Madrid, 1955, pág. 570.

6 "Contemporary Spanish Poetry", en The Texas Quarterly, pág. $S_{2}$ 
Pera, hechas estas objeciones, debemos reconocer que estos entusiastas esfuerzos de renovación y avanzada abrieron un haz de posibilidades, muchas de las cuales fueron aprovechadas por la brillante lírica posterior. El paso de la poesía post-modernista a la de la generación del veintisiete no se puede explicar totalmente sin reconocer esta etapa revolucionaria, que no sólo destruyó viejas fórmulas sino que abrió también caminos para la renovación de la expresión poética. Ultra logró cumplir su indeterminado propósito de llevar a la poesía hacia un "más allá", aunque, como dice Valbuena Prat, no llegara a la tierra prometida ?

Dámaso Alonso nos dice de Ultra:

No se le hace justicia a este movimiento. Apenas produjo nada durable. Pero sin él difícilmente se puede explicar la poesía posterior. Una parte del público rechazará siempre lo literariamente heterodoxo o innovador, sin comprender que sin esas sacudidas la vida de las letras se enmohece, que aun para la renovación de la literatura, dentro de los, cauces tradicionales. son necesarias de vez en cuando, esas, arriscadas aventuras ${ }^{8}$.

Y más adelante nos dice que "a través de muchos filtros, $y$ aun a veces por capilaridad, materia de aquellos atrevimientos, que ya podemos llamar de antaño, ha pasado a la técnica de los más perfectos..." ?

La búsqueda de las huellas ultraístas en la poesía de las generaciones posteriores sería motivo de un largo trabajo. Hay evidentemente una gran diferencia en la jerarquía poética, una transformación de la musiquilla ultraísta, en voluntad de forma, una asimilación de otras tendencias que exceden amplia-

\footnotetext{
7 Historia de la literatura española, II, Madrid, 1937. pág. 919.

8 Poetas españoles contemporáneos, pág. 245.

9 lbidem, pág. 246.
} 
mente a los aportes del Ultra: la raigambre en lo nacional y popular español, la influencia de Góngora, de Lope de Vega, del cancionero, etc. Dámaso Alonso nos dice que la poesía posterior "va a juntar a los más frenéticos anhelos de creación (sonda hacia el futuro) todas las conquistas formales de la poesía tradicional (ancla en el pasado)" ${ }^{10}$.

Pero los ultraístas habían creado un clima que los poetas que pertenecen a una generación inmediatamente posterior debieron necesariamente respirar.

El culto a la imagen influye, evidentemente, en los poetas del veintisiete. Encontramos en sus poesías numerosos ejemplos :

(Grulla dormida la tarde

puso en tierra la otra pata.)

(GARCía LORCA: Canciones)

$Y$ la luna picaba con un rayo en el agua.

(GARCía LORCA : Canciones)

Mil panderos de cristal

herian la madrugada.

(GARCía LORCA : Romancero)

Qué ajena tú, mi corazón cosiendo

al delantal de las riberas solas.

(ALBERTI: Cal y Canto)"

Recogen además la tendencia al juego intrascendente y despreocupado, a la cabriola humorística e ingeniosa; la libertad para saltar los límites que impone la realidad y para ligar poéticamente elementos heterogéneos (la equiparación entre lo cós-

10 Estudios y ensayos gongorinos, pág. 569.

11 Antonio de Undurraga en la obra citada ha confeccionado una larga lista de imágenes creacionistas en García Lorca y Alberti. Cf. págs. 97 a $10 \%$. 
mico y lo humano, por ejemplo). En algunos casos, una tipografía expresiva moderada y la supresión de los signos de puntuación.

Los ultraístas precipitaron además el individualismo y el irracionalismo.

La valoración de las profundidades humanas, del subconsciente, de los elementos oníricos, prepara la aparición del surrealismo español. Juan Larrea, sobre todo, fue en este camino un hito importante. Luis Cernuda le reconoce este papel: "...no creo equivocarme al pensar que a él debieron Lorca y Alberti (y hasta Aleixandre) no sólo la noticia de una técnica literaria nueva para ellos, ssino también un rumbo poético que sin la lectura de Larrea dudo que hubiesen hallado" 12.

Diremos por último que el ultraísmo dio abundante fruto en América.

Fue una etapa, cambió rumbos, creó una atmósfera, y sobrevivió, de alguna manera, en la obra de los grandes poetas de la generación siguiente.

12 Op. cit., pág. 194. Se refiere sobre todo a los poemas de Larrea publicados en Carmen, pero hemos visto que esta vertiente surrealista de su poesía se anuncia ya en la época ultraísta. 


\section{APÉNDICE DE DOCUMENTOS}

Incluimos en este apéndice documental, manifiestos, poesias y artículos críticos, extraídos casi todos de las revistas del movimiento. Algunos son ingenuos, confusos y de escasa calidad literaria, pero nos ha parecido interesante recogerlos para transmitir el "clima" ultraísta. 
PROCLAMA FUTURISTA A LOS ESPAÑOLES

¡Futurismo! ¡ Insurrección! ¡Algarada! ¡Festejo con música Wagneriana! ¡Modernismo! ¡Violencia sideral! ¡Circulación en el aparato venoso de la vida! ¡ Antiuniversitarismo! ¡Tela de cipreses! ¡I Iconoclastia! ¡Pedrada en un ojo de la luna! ¡Movimiento sísmico resquebrajador que da vueltas a las tierras para renovarlas y darlas lozanía! ¡Rejón de arador! |Secularización de los cementerios! ¡Desembarazo de la mujer para tenerla en la libertad y en su momento sin esa gran promiscuación de los idilios y de los matrimonios! i Arenga en un campo con pirámides! ¡Conspiración a la luz del sol, conspiración de aviadores y chaufeurs! ¡Abanderamiento de un asta de alto maderamen rematado de un pararrayos con cien culebras eléctricas y una lluvia de estrellas flameando en su lienzo de espacio! i Voz juvenil a la que basta oir sin tener en cuenta la palabra : —ese pueril grafito de la voz-! i Voz, fuerza, volt, más que verbo! ¡Voz que debe unir sin pedir cuentas a todas las juventudes como esa hoguera que encienden los árabes dispersos para preparar las contiendas! ¡Intersección, chispa, exhalación, texto como de marconigrama o de algo más sútil volante sobre los mares y sobre los montes! iAla hacia el Norte, ala hacia el Sur, ala hacia el Este y ala hacia el Oeste! ¡ Recio deseo de estatura, de ampliación y de velocidad! ¡Saludable espectáculo de aeródromo y de pista 
desorbitada! ¡Camaradería masona y rebelde! ¡ Lirismo desparramado en obús y en la proyección de extraordinarios reflectores! ¿Alegría como de triunfo en la brega, en el paso termopilano! ¡ Crecida de unos cuantos hombres solos frente a la incuria y a la horrible apatía de las multitudes! ; Placer de agredir, de deplorar escéptica y sarcásticamente para verse al fin con rostros, sin lascivia, sin envidia y sin avarientos deseos de bienaventuranzas: -deseos de ambigú y de repostería-! ¡Gran galop sobre las viejas ciudades y sobre los hombres sesudos, sobre todos los palios y sobre la procesión gárrula y grotesca! ¡Bodas de Camacho divertidas y entusiastas en medio de todos los pesimismos, todas las lobregueces y todas las seriedades! ¡Simulacro de conquista de la tierra, que nos la da!

\section{TRISTÁN}

(Seudónimo de Gómez de la Serna)

En Prometeo, tomo II, año III, núm. 20, ig ro.

\section{LO MAS HERMOSO}

Cuando en las vísperas de los domingos, nos reunimos, oh amigos, en el puro juibilo periódico, nuestras caras brillan en plenilunio; las manos del saludo están llenas de anillos, nuestros pies alados sienten la emoción fabulosa de las travesias extraordinarias, por entre islas llenas de vellocinos, $y$ nuestros ojos se dilatan atónitos viendo cambiarse el cielo de la noche en cada tránsito $y$ unirse 
todas muestras noches en una

sola maravillosa...

R. CANSINOS-ASSÉNS, en Grecia, núm. 17, 1919, pág. 5.

\section{LA EPOPEYA DEL ULTRA}

GESTA PRIMERA

Estamos en el Bar - bajo el estruendo agobiante de la pianola-. festejando el nuevo éxito de incomprensión que esta noche ha obtenido en el Ateneo Pedro Garfias, el fervoroso, disparando su ametralladora de estrellas sobre la plenitud de los oyentes.

Cuando salimos a la ancha plaza de las sesenta palmeras. en el gran sol nocturno del Consistorio, la larga mano negra del horario señala una hora seria y sugerente:

\section{LAS TRES}

Estamos ebrios de versos, aturdidos de pianolería, opilados de café con leche, vacíos de sueño. Nuestras ideas están acuarteladas.

Garfias habla en cubista. $Y$ ensaya unos insultos líricos a la respetable señora Luna, que por lo traída y llevada, bien merece un sillón en las Academias de todos los paises.

Adriano, incorregible corruptor de estrellas vírgenes, alza hasta tocar a Syrio con la mano, su brazo expresivo, a cuyo extremo se agita un puño suelto, deshilachado y rebelde, que es como la insignia de su bolchevismo sobre su uniforme del regimiento número to de infantería de línea. Sin rasurar, bajo su traje oleaginoso, parece por su aspecto bohemio, un superviviente de las huestes de Weyler... como debieron ser los soldados de Weyler.

Isaac "el porta-estandarte del ultra", esgrime su bastón, que antaño supo de las iras populares, dirigiéndolas, y señala 
conminativo, la brecha rectangular abierta en el centro de la plaza para erigir, ¡ oh, espíritu atávico de la Ciudad! un monumento a San Fernando.

Olmedilla, que ha comparado las palmeras a paraguas abiertos y rasgados, se horroriza pensando en el nuevo baldón que el alma vieja, cantigua?, no, ñoña, de Sevilla, va a infligir al alma "muy antigua y muy moderna", pero siempre elegante de la Ciudad. Y sin comprender lo estéril de su gesto, recoge unos cascotes de las obras municipales y los arroja al espacio que ha de ocupar la estatua del rey bárbaro, merced a cuyo esfuerzo Sevilla atrasó unos siglos en el camino de su civilización.

Es como vértigo iconoclasta que se apoderase de los cuatro noctívagos. Incansables, lanzamos nuestras piedras (no menos duras que los ripios de todas las octavas reales y todas las quintillas taraceadas por cuantos poetas ensalzaron a Fernando III). contra la figura imaginaria pero inminente ya del guerrero. Nuestros ojos parecen verla, avanzando un pie como un banderillero que cita al toro, el chafarote enhiesto en la una mano, amenazando las taifas... edilicias, y en la otra, la esfera terres. tre, verdinegra de herrumbre, como un buen queso de bola pedrido por la humedad de muchos inviernos. Como todas las malas iniciativas, ésta prosperará y tendrá un desgraciado término. A la inauguración asistirá cuanto en Sevilla tiene una significación tan oficial como funesta. El conde de Urbina estrechará la mano bellicida del escultor Joaquín Bilbao, hablando cínicamente, polichinelescamente, en nombre del Pueblo, y el concejal y miembro de la R. A. S. de B. L. don Santiago Montoto y Sedas, "el peor ripio de su padre", como le llamé en tiempos, leerá una espirada poesía tetrastrofomonoritmoalejandrina, exaltando el chafarote, el queso de bola y hasta la capa del rey de espadas del incorrupto conquistador.

Pero ya nadie podrá evitar, puesto que es un hecho consumado, el que unos poetas bolcheviques, sin ritmo y sin retórica. hayan lapidado "concienzudamente" — ¡ la única vez que 
pensamos ser concienzudos $I-$ la estatua nonnata de un militarote del pasado sangriento erigida en el centro de la Ciudad civilizada.

Cuando nos detenemos en nuestra empresa, bella por lo estéril y desinteresada, sentimos la embriaguez iconoclasta y en torno nuestro, como un moscardón indesahuciable que viniese de rondar un fósil prehistórico, runrunea un nombre: Montoto.

- Hay que comenzar la cruzada contra todo lo viejo -inicia Isaac-: convendría que empezáramos esta misma noche. ¿Cómo? Creo que no lo llegamos a discutir siquiera. Hubo un tácito pensar unánime que nos impulsó a ello. En el Bar de la piañola, que aún seguía embruteciendo con sus estridencias a los fámulos galaicos de don Germán, adquirimos los pro. yectiles: patatas y panecillos duros. (Nada de piedras. Es un honor que reservamos para adversarios más altos y menos febles.)

Pasadas. Cautela. Precauciones. Burlamos la vigilancia un tanto nominativa de los guardas nocturnos. Preparamos la retirada por la calle Mesón del Moro, por la de los Abades, por la de Fabiola, por la de Guzmán el Bueno -otro bárbaro-y después del momento inquietante y sugestivo de los grafitos en las paredes y en la puerta, nos aprestamos a la consumación de nuestro proyecto.

$\therefore$ Isaac está en su centro. $\mathrm{Va}_{2}$, viene, atisba, ordena en voz baja : el porta-estandarte del Ultra, ha asumido el mando supremo de los rojos ejércitos iconoclastas. Toda su alma de luchador, del gran conductor de audacias que hubiera sido, resplandece en este momento en su mirada, en su ademán, en su palabra. ;Ultra!

Es la consigna. A este grito, hay un verdadero fracaso de cristales. Pedro Garfias, circunspecto y tácito, alza el brazo y arroja sus proyectiles con la violencia bíblica de un profeta que

BL ULtraísmo. - I2 
lanzara una imprecación divina sobre los incrédulos. Adriano del Valle, bolea el puño como un hondero balear, y hace dos impactos de un solo coup de pomme de terre; Isaac del Vando. como una catapulta, hace girar el brazo pesadamente, y su patata -un kilogramo de tubérculo- atravesando la ventana, va a romper como un obús, la vidriera del patio; yo cumplo con mi deber, aún me excedo, estoy seguro de haber roto el busto de Rodríguez Marín -el enemigo de Cervantes- que alboreaba en las sombras de la Biblioteca montotina, y que al caer produce un sordo ruido de adoquín sobre el entarimado.

Cumplida nuestra misión nos dispersamos. Adriano huye célere, como buen soldado. Isaac aprieta el paso, para organizar el cotidiano ágape auroral. Yo me pierdo en las calles del barrio de Santa Cruz. Garfias, se hunde en la sombra para copular con una luna apagada.

Juan González Olmedilla, en Grecia, núm. 42, 1920.

\section{LA NUEVA LfRICA Y LA REVISTA CERVANTES}

Al abandonar Andrés González-Blanco la dirección de la revista mensual Cervantes, para asumir la del moderno rotativo madrileño La Jornada, Rafael Cansinos-Asséns, el evangélico maestro de nuestra literatura contemporánea, ha sido el escritor designado para presidir el prestigiosísimo comité de redacción que ha de señalar nuevos rumbos a tan pulcra como bien orientada publicidad hispanoamericana. Nunca, por tal motivo, más justas que en estos instantes - como salutación cordial al maestro que se retira y al maestro que adviene-, las esperanzadas palabras de optimismo del hércules viejo de Manhattan: "Detrás de todo Adiós se oculta, en gran parte, el saludo de un Comienzo nuevo". 
Estas palabras que mi fraternal corifeísmo literario hacia Cansinos-Ásséns me dicta están justificadas por la pródiga y valiosa labor de hermenéutica realizada por el joven maestro al darnos a conocer el fruto de sus exploraciones por las selvas $\mathrm{fa}$ bulosas de los herméticos países del Arte nuevo, por cuyo motivo presumimos que la revista Cervantes, bajo su sabia dirección, se alzará en un mañana no lejano como el arco de triunfo por el que nos entrará, desde el oriente azul de los horizontes infinitos, la luz de las más maduras y meridianas auroras de la nueva lírica.

El arte nuevo no asume para sí la justísima denominación de Ultra por los moldes o crisoles métricos en que aspira a ser fundido, sino por el ansia de concepciones amplias, de introspectivas visiones ilimitadas, que anhelan percibir, para grabarlas al rojo, estos modernos cabiros que se agrupan en torno a los nuevos yunques, en contraposición al anhelo retromilenario que sienten los rezagados monjes miniaturistas que aún trasudan sangre, a prueba y paciencia de buril y de estilo, en derredor a los apolillados códices de rimas del novecientos.

Gracias a la generosidad franciscana de Cansinos-Asséns, el Adelantado más lírico y avizorante de cuantos atalayan desde los Pirineos espirituales de nuestra República de las Letras, el marinettismo furioso que pedía la demolición de las piedras sagradas de las Mecas del arte para erigir en sus solares grandes fábricas de conservas, ha llegado a nosotros atemperado por los balsámicos nepentes de la moderna lírica francesa que de una forma tan varia, tan rica en matices y tan pródiga en nuevas sugestiones, ha sabido blindar esas torres elefantinas del arte contra las melinitas verbales de Marinetti y su banda de revolveratori.

Esta novísima escuela literaria, aparte de las concomitancias - no muy lejanas - que con la del autor de la "Canción del automóvil" pueda tener, no es originariamente francesa puesto que Walt Whitman, en quien tanta prolífica semilla se 
encuentra de lo que en el nuevo arte es campo de trigo sazonado, nació en Long Island...

En cuanto a su absoluta modernidad en las letras francesas, en el cetro lírico del emperador del simbolismo, el divinísimo Stéphane Mallarmé, ya fulguraron algunas de esas estrellas maduras que estos modernos aedas democráticos arrancan de los cielos, con la seriedad grotesca de los Frank Brown circenses, para encender impávidos sus viejas pipas de argonautas.

Guillermo Apollinaire, bien conocido con antelación a su iniciamiento en los nuevos ritos líricos por sus traduciones del Aretino y sus poemas, puede decirse que ha sido, con Klingsor, Frick, Pedro Reverdy - el autor de Nómada, ese poema que tiene la visión simultaneísta del arte de Picasso- Blas Cendrars, Max Jacob, Luis Chadourne, Roger Allard, Luis de Gonzaga y el chileno Vicente Huidobro, el cimentador de la moderna escuela que tiene su más convèrso representante en las letras alemanas en la modalidad literaria de Ruywerner y en las de Rumania en los álveos métricos de Jacob Zara.

Entre nosotros, Juan Ramón Jiménez, el enamorado novio de la luna, ese lírico príncipe que tiene el alma enferma de primavera y el corazón ulcerado por las estrellas de la noche, expresó la melancolía osiánica de su estro en nuevas modulaciones verbales en las que retornó a una edénica despreocupación en el verso, en cuanto a revestirle con los ropajes purpúreos del consonante y de la musicalidad rítmica del metro se refería.

Y toda la admirable labor exegética y la potencialidad plástica del verbo cálido de Rafael Cansinos-Asséns esforzado en sustentar sobre sus hombros, como fabuloso Atlante, el orbe de la nueva lírica - que va encaminada a nutrir en las mamas inexhaustas del nuevo Arte a los jóvenes epígonos que salen de las pagodas búdicas y de los fumadores literarios del novecientos a contemplar por primera vez, y cara: al sol del Mediterrá- 
neo, un mundo nuevo, pletórico de primiciales dones-, ha conseguido hacer decir, al fin, sus más sinceros cantos a los jóvenes poetas que se llaman: Rogelio Buendía, José María Romero. Xavier Bóveda, Isaac del Vando-Villar, Luis Mosquera, Salvador Valverde, Pedro Garfias, César A. Comet, Eliodoro Puche, Correa-Calderón, Guillermo de Torre, J. Rivas Panedas, Iglesias Caballero, Quiroga Pla, Goy de Silva, Antonio Espina García y otros muchos conversos oficiantes en los nuevos ritos líricos del Ultra...

Hoy, a las revistas Nord-Sud, Soi-même, Sic, Magestic, y a cuantas son órganos de los ardorosos y juveniles cenáculos literarios, bien puede unir su nombre, que ya tiene el prestigio. glorioso de un lábaro de batalla, la europeizada revista Cervantes. En ella está Rafael Cansinos-Asséns, el sembrador...

Y esas siembras que el maestro hace tendrán las hoces más esforzadas en los brazos de los jóvenes poetas que sientan sed de horizontes y hambre de escalar las más elevadas cumbres.

Porque una escuela aún inmatura, en la que hay muchas fuentes selladas que hacer brotar, muchas florestas que recorrer, muchos horizontes y colinas que alcanzar, requiere corazones de coribantes, exaltaciones dionisíacas en las pleitesías de los peritatéticos (sic), vastos alientos herácleos y fuertes impulsos triptolémicos que pongan abrazos de muerte para la cizaña literaria, en los relámpagos de acero de las hoces que han de empuñar los brazos de los corifeos juveniles.

ADRIANO DEL VALLE

Grecia, núm. 12, año II, Sevilla, $1 .^{\circ}$ abril 1919, págs. I2, I3 y 14.

\section{DE LA FIESTA DEL ULTRA}

Lo mismo que en el gobierno de los pueblos, los más fuertes se erigen en dictadores, unos hombres de nuestra misma sus- 
tancia, redactaron el Código de las Letras y nos dijeron: "Esto debes hacer", conforme a su juicio. Pervertidos por la falsa creencia, nos propusimos resucitar el Pasado. $Y$ al hombre no le fue dado poder para resucitar, sino para crear. Engendramos un hijo, pero no levantamos a nuestro padre del sepulcro.

Si por esto se nos ha de tachar de irrespetuosos con los clásicos, cometeréis una liviana acción. ¿Faltamos, por ventura, al respeto y admiración que debemos a nuestros abuelos, porque no vestimos como ellos? ¿Qué se diría del que saliese hoy a la calle ataviado a la moda del siglo XV? Nosotros sentimos por los clásicos el respeto mismo que ante los retratos de nuestros antepasados - ya un poco borrosos, donde brilla como un relámpago el saliente de la armadura, o la rizada gorguera nos muestra la cabeza cana y algo lívida, con el sadismo de una Salomé...-. Respeto a los Clásicos, sí. Afecto, tal vez: el afecto que podamos profesar a un pariente lejano.

$¿$ Que debemos a los progenitores el patronímico que nos escriben en la cédula personal? De acuérdo. Pero, decidme ahora, ¿jamás os inquietó la duda de si nos corresponde verdaderamente? iSe nos han entregado tantas mujeres que no eran las nuestras!

$$
\text { *** }
$$

El Ultra es, ante todo, sinceridad. La sinceridad es afirmación.

No quiere decirse que el Ultra desdeñe o abomine de la forma. Ningún escritor de la lengua castellana más delicado y sutil en la forma que Cansinos-Asséns. Lo que desdeñamos nosotros no es la forma : es la imitación servil de los antiguos, el amaneramiento literario. Cada escritor tenga su estilo personalísimo; pero éste no se consigue sino expresándose con ingenuidad. Lo otro que llaman estilo es artificio sin emoción ni raíces; algo exterior que no conmueve: lo mismo que la fruta, 
nos seduce por el color o la finura de la piel: al comerla, tiramos la cáscara, desdeñosamente, y nos reservamos la pulpa. Los plagiadores de los clásicos me representan a Brocas partiéndose una pierna para imitar la cojera de Romanones.

No es de importación extranjera la tendencia ultraica, si bien lo parece a la primera mirada. Los precedentes de Marinetti. Apollinaire, Max Jacob y otros no fueron sino precedentes. Antes de que Jesús predicara en Judea la nueva doctrina, la había presentido Juan en el desierto y en el nombre del que había de venir administraba el bautismo. Nació aquí en esta Sevilla sin adjetivos; porque no hay adjetivo castellano que retrate la hermosura de la ciudad, ni la generosidad de sus hijos, ni la gracia de sus mujeres. Del Ultra se podrá decir con verdad lo que las madres mienten a los pequeños curiosos de su origen: "Nació en una canastilla de flores".

¿Será Sevilla para el Ultra lo que Nazaret fue para el Cristianismo? ¿Tendrá el Ultra como el Hijo de María, que refugiarse en la hospitalaria Cafarnaún?

Pedro Luis de Gálvez

En Grecia, Sevilla, 20 mayo 1919, núm. 16, págs. 2, 3 y 4.

\section{MOSAICO LEIDO POR JUAN GONZALEZ OLMEDI- LLA EN LA FIESTA DEL ULTRA}

Queridos enemigos nuestros, isalud! (¿Cómo no llamaros enemigos, si hemos venido a deciros la palabra novísima, si hemos desplegado ante vosotros la bandera que no esperaban ver vuestras pupilas, acostumbradas todavía a los siete colores 
del iris, y sorpresas ahora ante una luz no registrada por vuestra suficiencia en la pantalla?)

Salud, pues, queridos enemigos, para que vuestro escepticismo displicente, alcance el alba, no lejana, de nuestra victoria. No hablo, claro está, del triunfo personal de cada uno de nosotros, en el estadio de la vida, sino del éxito multánime.

\section{$* * *$}

La atmósfera ideológica universal estaba henchida, hace años, de un vago anhelo de superación, de un indefinido afán de nuevas vías. Y la guerra, con su violenta conmoción, con el saldo total de los valores espirituales vigentes hasta ayer, ha irrumpido en la florida ciénaga de la civilización moderna, para señalar con el rojo índice destructor y purificador, los nuevos caminos del pensamiento humano. El arte, la política, el derecho, la misma ciencia, tienen que cegar los viejos cauces por donde se deslizaban y hacerse, paso a paso, con la fervorosa tenacidad de los exploradores, sus nuevas sendas. El mundo ha sentido crujir su eje; una fuerza telúrica no sospechada, ha lanzado al espacio los polos del planeta, como la fuerza centrífuga de una marmita llena de agua hirviente, que lanzase al cielo ennegrecido de la chimenea, la tapadera que la cubría. $\mathrm{Y}$ cuando todo cambia ¿los poetas, "pararrayos celestes", erguidos sobre la humanidad para recibir los teogramas del Verbo, habíamos de permanecer extasiados en la contemplación e imitación de lo antiguo, enmarañados en la selva retórica del pasado, indiferentes a las nuevas inquietudes, a los temas intactos que nos brinda el panorama vital de la post-guerra?

$$
* * *
$$

El ultraísmo es una ansia de más allá, de superación ; y más que eso, a mi entender, un anhelo de rutas no halladas. Max Jacob, una de las más altas atalayas de la nueva lírica, ha dicho - recordando a los griegos - en el prólogo de ese raro y 
desconcertante Cornet à dés (París, 1906): "El arte es, propiamente, una distracción", es decir, agrego yo, un juego de almas cándidas, un juego de seres puros. Por tanto, al arte no se le debe exigir nada, sino la gracia y la alegría de un juego. Los poetas debemos reclamar la irresponsabilidad de nuestros cantos, ante el ojo desmesuradamente abierto y duro de la crítica. (Ya Emerson había dicho, con divino desdén: "No puedo perder el tiempo en explicaciones". ¡Hermosas palabras de aristo, que debian ser el lema del Ultra, frente a la perspicacia de los filisteos! Y Oscar Wilde ha afirmado, recabando para el arte la suprema libertad de sus intenciones: "El Arte es perfectamente inútil").

Volviendo a Max Jacob, y para terminar el ciclo de las citas, repetiré aquí sus palabras: "Una obra de arte vale por sí misma, y no por la constatación que de ella puede hacerse con la realidad".

\section{***}

¡Gutierre de Cetina ha muerto! ¿Comprendéis, queridos enemigos, el sentido de esta novísima afirmación?

Quiero valerme de un tópico literario, algo usado ya, para enterrar definitivamente a Gutierre de Cetina:

"Ha muerto Cetina, el de los madrigales inimitables". Y como sus madrigales, por serenos, por puros, por diáfanos, por nuevos (en él), son inimitables, nosotros debemos, respetuosamente, amarlos siempre, leerlos en el momento oportuno... y no imitarlos jamás. Esto mismo podemos decir de Góngora, de Bécquer, de Rubén Darío y sus apóstoles, los maestros novecentistas después del tránsito de Rubén a la región definitiva de lo que, por pasado, no pueden trasmutarse ya, debemos cerrat no ya con siete icon siete mil llaves! el palacio magnífico del Modernismo - que ya logró su plenitud, su madurez y su ocaso- y emprender la tarea de erigir las nuevas estaciones radiotelegráficas de la Lírica. 
Al novecentismo no podemos asomarnos sino como a un museo pleno de obras maestras del pasado.

Los hermes que culminaron en la cruzada contra los hueros cantores finiseculares, duermen ahora de magistral reposo, en las páginas de los libros que no debemos imitar. Hay que leerlos para comprender que su valor está en su originalidad, no para aprender de ellos; comprendiendo, crearemos; aprendiendo no haremos sino imitar a los clásicos de esta o la otra escuela. Para ser clásicos nosotros algún día, debemos empezar por fundar la nuestra. Vamos, pues, contra la Retórica - j oh la oquedad sonora!-; contra los tópicos, contra la afectación, contra el preciosismo, contra la riqueza de la Rima - joh, los sepulcros blanqueados!- ; contra la discreción, joh el sentido proporcional, que limita nuestra sinceridad emotiva, diciéndonos: "esto puede cantarse en versos de ital medida; esto otro no puede decirse ni en prosa!".

\section{$* * *$}

La nueva lírica arranca de 1906, con Max Jacob; y forman en sus avanzadas Klingsor, Paul Fort, Saint-Pol Roux, Apollinaire, Allard, Frick, Cendrars, Reverdy y Huidobro que, aunque de sangre y habla hispanas, ha escrito en francés sus poemas más interesantes, influido durante la guerra por su amistad con Reverdy y otros poetas de Lutecia.

En España, mucho antes de que Vicente Huidobro nos trajese la palpitación de las nuevas alas, ya Unamuno -el gran poeta sitibundo de horizontes sin mácula - había ensayado a cantar su universo con una voz no oída antes, con un acento entrañable, lleno de la más recóndita sinceridad. Y Ramón Pérez de Ayala, en el Sendero innumerable, como Juan R. Jiménez, en su nueva contorsión lírica del Diario de un poeta recién casado y Eternidades, como Lasso de la Vega, Mauricio Bacarisse y José Moreno Villa en sus colaboraciones para revistas, también osaron explotar los nuevos caminos. 
Ya en 19ro, en la Revista Prometeo, iniciaron un balbuciente temblor de anunciación Rafael Cansinos-Asséns y Ramón Gómez de la Serna, aquél con sus psalmos y éste con sus greguerías, que tuvieron años después, una magnifica plenitud de intenciones realizadas en sendos libros ubérrimos: $E l$ candelabro de los siete brazos de Cansinos, y Greguerías de Gómez de la Serna. Simultáneamente, Xenius en Cataluña y Jacinto Ilusión en Sevilla, clavaban en la plenitud estupefacta de los lectores incomprensivos, aquél la piedra de su honda mediterránea, éste la saeta de su finura bética.

Aquí mismo, en Sevilla, José María Romero, apenas hundida en los almacenes de los libreros la edición de su obra primigenia - llena de resonancias novecentistas- ¿no se lanzó a los amplios espacios del Verso libre y de la Rima arbitraria, no surcados antes por los nietos de Herrera, mal nutridos en las exhaustas ubres rodriguemarinescas?

Rogelio Buendía, el sutil y señorial poeta, de graciosos vuelos, rebeldes a todo canon de la lógica y del sentido común -el más gregario de todos los sentidos-, ¿no pudo también libertarse a tiempo de la fascinación de los espejos magistrales?

\section{***}

Pero todo esto no ha sido sino un movimiento precursor, un estremecimiento celeste para anunciar el alumbramiento de una nueva estrella lírica: $i \mathrm{El}$ Ultra! hay que decirlo claramente, con claridad ultraísta: Rafael Cansinos-Asséns el más alto y amplio y complejo espiritu de artista que ha engendrado Sevilla modernamente, ha sido el verdadero creador de esta tendencia. Y ha sido la revista Grecia, que florece en las márgenes del gran rio, la publicación que primeramente y con amor más fraternal y asiduo, ha acogido las palpitaciones apasionadas de ese gran corazón de poeta, desterrado de la mejor ciudad por las incidencias de la vida. Aquí, pues, en Sevilla, es donde en verdad, ha nacido y arraigó la nueva Escuela literaria, sus- 
tentada por un artista sevillano - Isaac del Vando-Villarhenchida y colmada con las ofrendas líricas de poetas sevillanos, llena de acogedora amplitud para los epígonos que en $\mathrm{Ma}$ drid siguen, con atónito fervor de alumnos, el verbo parabólico de Cansinos-Asséns.

$$
* * *
$$

$Y$ ahora, quiero terminar diciéndoos:

No deseamos adeptos ineptos, sino almas comprensivas que. mortificadas en los matraces de las técnicas literarias más exigentes, estén ya aptas para derramar el caudal cordial de sus. emociones en las formas amplísimas y aladas de Ultra.

A los jóvenes inexpertos, a los que aún no conocen la amarga ciencia de la Rima, recomendamos que primeramente hagan muchos sonetos, que se torturen en los viejos moldes, que beban con unción de acólitos en los odres clásicos, para escudriñar, con los ojos embriagados por el vino lírico de antaño, los secretos del Verso, dormidos en el fondo de las antiguas copas. Sólo entonces, deben arrojar contra, el suelo los vasos canónicos, y acercar sus bocas a los claros manantiales libres de la nueva Estética.

Juan González Olmedilla

En Grecia, año II, núm. XVIII, Sevilla, ıo junio Igıo, páginas $\mathrm{I}, 2$ y 3.

\section{INSTRUCCIONES PARA LEER A LOS POETAS ULTRAISTAS}

Para leer a los poetas nuevos, que por su originalidad pueden parecer oscuros a una atención tradicionąl, no iniciada en las nuevas formas, se ha de tener presente que toda poesía es. un valor convenido entre el poeta y el lector, una ecuación en suma, cuya fórmula establece el autor, contando con la pers- 
picacia de los lectores, con una adivinación que no puede faltar, ya que, por muy oscuro que sea el lenguaje empleado, su solo empleo es ya un nexo brindado a la comprensión, mucho más asequible que el de las fórmulas algebraicas. No hay poesía totalmente incomprensible, ya que siempre, no obstante lá suma máxima de su originalidad, ha sido concebida por una mente humana y expresada en un lenguaje hablado $y$ asumible en cualquier diccionario. En realidad, por mucha que sea la originalidad del poeta, por lejos que vaya a buscar los motivos y formas de su inspiración, nunca logrará romper por completo los hilos telefónicos que le unen con los demás cerebros ni borrar por completo la huella denunciadora de su paso por las urbes intelectuales. La poesía más oscura siempre transparenta un rayo de claridad perceptible por nuestra retina y siempre nos brinda, aunque sólo sea mediante una palabra clara de nuestro lenguaje, el nexo referible a lo conocido. En presencia de un nuevo modo de poesía, se habrá de buscar, pues, la fórmula de la ecuación que en ella se nos ofrece, la fórmula nueva mediante la cual expresa disfrazándolo, un aspecto de la eterna analogía percibida por el arte. Esta fórmula es más o menos asequible, mas nunca totalmente hermética, ya que hasta con la simple coordinación de palabras, como ocurre en los delirios apreciables por el termómetro, nunca falta un nexo de asociación que permite formar oraciones completas, por un procedimiento semejante al que se sigue para llenar las tiras telegráficas. El célebre poema de Montesquiou de Fezensac no es sino un poema deductible. La oscuridad aparente de un poema, sólo debe indicarnos un plazo temporal más o menos largo, necesario para la comprensión de su fórmula. En los modos de poesía, sistemáticamente cultivados durante largo tiempo, esa fórmula llega a ser popular, ni más ni menos que la que permite practicar una suma. El arte procede por analogías, y es claro u oscuro en la medida que estas analogías puedan ser apreciadas. Cuanto más explícito sea un arte, tanto menos oscuro ha- 
brá de ser. Así el arte clásico que expresa las analogías tan explícitamente en Homero y Virgilio.

Cuando Homero compara un ejército con un rebaño, ninguna duda es posible, y toda diferencia queda inmediatamente salvada por la imaginación para que sólo la analogía persevere. Cuando nuestro Fray Luis de León dice: "El pecho sacó fuera el río", la imaginación percibe también al punto una analogía a la que están acostumbrados los sentidos, ya que ha existido un modo tradicional de figurar místicamente a los ríos con forma humana, no sólo en poesía, sino en escultura, en el arte pagano. La prosopopeya, pues, resulta perfectamente comprensible. Nótese de paso cómo la escultura y la pintura ayudan a la comprensión de la imagen poética, dotándola de una viabilidad sensualmente perceptible. El arte romántico altera la fórmula de la ecuación poética, y al punto es tildado de enigmático. Sus modos predilectos son la hipérbole y la antítesis -Dios y el gusano, el hombre y la montaña-, expresa sentimientos desmesurados y sutiles, cosas no contrastables inmediatamente con las obras de las artes plásticas ni apenas representables para ellas. Su fórmula sólo es sorprendible por una sentimentalidad desesperada. De aquí la sorpresa con que es acogido por los devotos del arte clásico, que lo declaran oscuro. pues la hinchazón que le reprochan alude a su oscuridad. Sin embargo, la poesía romántica es bastante explícita, y su amor al paisaje y a la anécdota la inclinan a representar cosas perceptibles por los sentidos. En menos de diez años, ya el público ha sorprendido su fórmula. Después de los románticos parecen oscuros los simbolistas, los decadentes, los ultrasimbolistas. Mallarmé es considerado como la Sibila de París, no menos tenebrosa que las de Libia y Cumas. Los críticos declaran no entender sus oráculos, pese a las exégesis de Teodoro de Wyzewa. Sin embargo, la poesía de Mallarmé no tiene nada de oscura cuando se estudia la fórmula de su ecuación. Basta tener en cuenta que la estética simbolista - no simbólica- 
presenta esa ecuación implicita, sugerida. Fía en el poder evocador de la palabra principal y rehusa las amplificaciones, aboliendo los nexos y las palabras-puentes, sólo utilizables en la cirugía dental para oradores. La fórmula es aquí tácita; se la encuentra precisamente al margen de la letra, y nunca falta, pues bastaría llenar ese margen para que apareciese explícita. Se ha comparado a Mallarmé con-Góngora y ambos son comparables, desde el punto de vista de la elipsis y del hipérbaton; pero estas condiciones no pueden ser reprochables, ya que son virtudes enteramente clásicas.

Góngora, sin embargo, prefiere el lenguaje conceptuoso, un lenguaje perfectamente comprensible, sin más que referir siempre el concepto abstracto al término concreto que define parabólicamente, cosa fácil, ya que el estilo conceptuoso es siempre demasiado explícito. Mallarmé, en cambio, aspira a sugerir, a economizar los medios verbales; de aquí sus frecuentes epifonemas, que dejan eternamente en suspenso el sentido; para entenderle es necesario suplir las palabras que él nos niega, completar su visión, como se hace con la pintura. Los modernos poetas cuya lírica evoluciona paralelamente al cubismo pictórico, pretenden extremar la posibilidad de sugestión, haciéndola múltiple. Obtienen la imagen duple o triple, como flores polipétalas, mediante una más alta presión en sus invernaderos. Dan así imágenes desdoblables que desorientan a primera vista; pero sólo se trata de una forma de ecuación más compleja, un poco más difícil, porque resume dos o más analogías, pero obtenible siempre por diálisis separadas. Cuando Huidobro, dice, por ejemplo: "Los pájaros beben el agua de los espejos", no hace sino resumir en una dos ecuaciones: "El cristal de los espejos es como un agua". "Los pájaros sedientos picotean el cristal de los espejos, semejante a un agua". De igual modo podrían explicarse otras imágenes modernas, obtenidas mediante síntesis abreviativas que nos hablan de una gran pericia en el artista o de una gran perfección en su instrumento. 
Estas imágenes sorprendentes, al pronto inverosímiles, se justifican siempre que se las desdobla en sus elementos. Porque siempre existe un nexo que permite su comprobación. Así, cuando Apollinaire dice "un regimiento de días azules", refiriéndose a los reclutas que visten de azul, como los días claros, y evocan el buen tiempo, puesto que son jóvenes, cuando Reverdy habla de las aceras que pasan por delante de él, sugiriendo una ilusión óptica muy frecuente, y hasta cuando Tristan Tzara une simplemente estas palabras: "suburbio camisolas". Trátase de una poesía rápida, comprimida, que responde a la multiplicidad y rapidez de la vida moderna, y que a veces toma sus formas de expresión al lenguaje corriente - ¿no son hoy frecuentísimas las aposiciones en el lenguaje mercantil y mundano: liquidación - verdad, señor bien, y no denominan los industriales productos complejos de sus manufacturas con nombres híbridos, como "velursine y toillaine", que en Francia indignan tanto a los críticos como los poemas cubistas? Se trata del empleo de fórmulas de ecuación sorprendentes, mas siempre comprobables, pues siempre, toda poesía, obra de mixtificación, ya que suplanta la realidad por una imagen, ha de conservar un nexo con esa realidad que permita entrever la realidad de la suplantación.

R. CANSINOS-AssÉNS

En Grecıa, año III, núm. XLI, 29 febrero 1920, págs. I y 2.

\section{ARTE NUEVO}

Esto del Arte nuevo es viejo. Siempre ha habido Arte nuevo, es decir, por más estéticas avanzadas en relación con las ya consagradas, académicas, aquéllas acaban fatalmente en éstas.

Parece que la lucha entre jóvenes y viejos es ahora más fuerte y que los vanguardistas destruirán de una vez el acade- 
mismo. No. Lo que ocurre es que hoy todo adquiere mayor violencia, por el estado de crisis que en todos los órdenes de la vida atravesamos.

Precisamente tal unanimidad evolutiva es la que nos garantiza que los actuales ensayos literarios y plásticos, no carecen de razón de ser.

El futurismo, el creacionismo, el expresionismo, etc., son tendencias gemelas que significan el mismo fin: la superación real. El mismo medio: la renovación técnica. El mismo principio: la rebelión hacia lo viejo.

Claro que el noble deseo de avance nos lleva muchas veces hasta la extravagancia. Pero hay que tener el valor del ridiculo. Detrás de él puede latir una verdad. Si los motivos humanos no varían, su manera de verlos y sentirlos, sí varía. La literatura, forzada dentro de los límites de lo definible, es impotente para expresar matices, sutilezas, ambigüedades del alma moderna, que no sólo provienen de ideas completas, sino de la sensación oscura, de latencias insospechadas, del absurdo. Lo indefinible no excluye posibilidad de expresión desde el momento en que dos o varias sensibilidades pueden relacionarse por estímulos aparentemente disparatados. Sugerencia.

De aquí, el esfuerzo literario en llegar a esa totalización interna, que en Pintura se ha llamado visión integral. La visión integral es la representación del objeto, según todos los sentidos corporales. Su triple forma, afectiva, emotiva e intelectual. $\mathrm{El}$ análisis, incluso físico, del objeto. En poesía sería la imagen dotada de su máxima capacidad fantástica.

Hay quien afirma que todo esto no son más que palabras. Que los valores absolutos son ajenos al arte y perjudiciales.

No lo negamos. Quizás. Pero como tal absoluto nos obliga a perseguirlo con tenacidad, aun conociendo de antemano la ineficacia de nuestros esfuerzos.

Además, algo se logra.

eL urtralsmo. - 13 
Lo inadmisible es pretender estancarse en una fórmula exclusiva. El Arte, por lo menos, debe variar a compás de nuestras propias transformaciones. La retina modificada por agentes desconocidos antaño (el arco voltaico, los colores químicos) exige nuevos reactivos cromáticos que los pintores modernos intentan, persiguiendo una especie de lenguaje articulado de la luz y del color. En el cerebro se funden sensaciones de diverso origen. El oído tiene su escala luminosa y táctil, y el gusto determina volúmenes e imágenes.

Todo el Arte moderno digno de este nombre es un Arte de ensayo.

Como tal me parece que es acreedor de algún respeto.

\section{***}

La gente, ante el espectáculo de lo nuevo, adopta una de estas dos actitudes:

Negativa, de los que rechazan, sea lo que sea y como sea. Positiva, de los que procuran admitir, tolerar y comprender.

La intransigencia de los primeros es sólo comparable a la intransigencia del modernista para con lo arcaico. Éste también es negativo a su manera.

$\mathrm{Ni}$ todo lo pasado es malo (¿qué es esto de malo y bueno?) ni es bueno todo lo actual. Del pretérito quedará lo que tenga valor de permanencia. De lo actual, lo plenamente logrado.

No el vano alarde, atormentado sin espíritu, raquítico y bastardo, más viejo que todas las vejeces, sino lo conseguido con sinceridad.

Ya sabemos que el ejercicio de la libertad produce indecisión en el público (no importa) y lleva al artista a la pose y a la farsa. Pero éstos son males menores.

¡Padecemos de Museo y de obra clásica! ¡Admiramos y nos aburrimos...! Nos gusta la Mezquita, pura de estilo, pero también nos produce un encanto inédito, convertida en Central de Telégrafos. Somos nerviosos e inquietos. 
$Y$ el efecto de tantas inquietudes comunes a tanto especulador de la belleza se manifiesta principalmente en la poesía, en el acervo lírico.

\section{***}

En España, la influencia poética extranjera, más bien francesa, dio su primer impulso hace años, cuando la mayoría de los portalira indígenas aún se andaban en el buen Zorrilla (Don José), muy respetable por otros conceptos, y en los "suspirillos. germánicos" de Bécquer (don Gustavo Adolfo), no menos respetable. La renovación lírica inglesa (Tennyson, Swinburne, Keats, etc.), la poética francesa (Baudelaire, Verlaine, Mallarmé, Rimbaud, etc.), nos llegó en gran parte desde América y especialmente confluenciada en el magno y divino Rubén.

Nombres, aún los más próximos - oh ¡efimeridad de las. cosas humanas! - ya lejanos y hasta clásicos en 1920. En. I 920 nos encontramos en una situación parecida a la de 1900 . No existe en todo el orbe de la Mancha, fuera de los que "han llegado", ningún poeta novel con suficientes hemistiquios para imponerse. No se oye una mosca lírica... Únicamente el ultraísmo. Pues el ultraísmo, ¿es una cosa seria? Les diré a ustedes.

El ultraísmo no es una escuela, ni una doctrina, ni casi una comunidad literaria. Es apenas una orientación y un buen deseo. Al ultraísmo - ¿para qué vamos a andar con rodeos?le falta talento. Exceptuando a Gerardo Diego, Vando-Villar y algún otro, está formado por una colección de señores muy simpáticos todos, pero de pocas ideas en la cabeza. Se nutre de escritores faltos de sindéresis o de fracasados de otros sistemas.

No existe paridad entre la labor personal de cualquier ultraista y la de un Reverdy, Cendrars o Apollinaire -oh i la terrible lata que nos han dado con este últimol- aun siendo los citados, poetas de segundo o tercer orden. Tampoco es un 
dadaísmo, jugueteo que no tendría aclimatación en nuestro ambiente. El tan cacareado poeta trasatlántico y bilingüe Vicente Huidobro es una calamidad. $\mathrm{Ni}$ es nuevo, ni es original, ni escribe bien. Decir que las estrellas son frutos celestes o que los aeroplanos parecen pájaros, sobre ser vulgar no ofrece ningún interés.

En una palabra, con el ultraísmo literariamente, no pasa nada. Algunos poetas suyos, los que como hemos dicho antes tienen talento, harán su obra personal si pueden y se salvarán solos.

Pero, si como escuela literaria no es nada, como fermento nihilista, subversivo, ácido, aunque de poca fuerza, nos parece admirable. Por mi parte (si me es lícito hablar de mi modesta persona) en este sentido soy del ultra hasta la médula de los huesos. Precisamente en el momento en que escribo este artículo, tengo el gusto de enviar una poesía a la revista Grecia.

Hace falta anarquizar, oxigenar, liberalizar.

Vivimos todavía en tiempos en que, decir que Núñez de Arce era un poeta de cemento armado, o que Campoamor -como escribe Baroja, no recuerdo dónde- hacía aleluyas de notario triste, produce consternación a las personas ortodoxas.

Antonio Espina García

En España, núm. 285, 16 octubre 1920, págs. I 2-13.

\section{OTRA VEZ HERRERA Y REISSIG}

Merecedor es el señor don Manuel A. Bedoya de una respuesta a sus afirmaciones estéticas añadidas como comentario al reseñar una fiesta de audacia, juventud y arte nuevo. Su conducta personal, su atención y compostura durante la fiesta fueron dignas de ser tenidas en cuenta. El señor Bedoya que ocupaba un asiento en las primeras filas, parecía un buen alumno 
discreto y comedido en una sala de estudios en que el mayor desorden estuviera representado - claro es- por los "últimos de la clase". No he de ocuparme lo más mínimo de las manifestaciones de cierta manada de palmípedos, de los cuales el menos desconocido e insignificante era Juan José Llovet.

Con espíritu zumbón y maligno, pero con indiscutible fidelidad en cuanto a los hechos, el señor Bedoya dio cuenta en La Voz de las peripecias del festival ultraísta. En consonancia con el espíritu y el título del artículo: "En plena apoteosis del disparate", ciertas aseveraciones hubieran podido ser disculpadas; pero como bajo el epígrafe de "Unas cuantas apostillas en seric", pretendía, ambiciosamente, el señor Bedoya explicar la génesis de una escuela, es menester aclarar más de un aserto turbio, confusamente henchido y descabellado.

Me permito aconsejar al señor Bedoya que busque en $\mathrm{Ma}$ llarmé y en los poemas en prosa de Arturo Rimbaud los orígenes de la escuela creacionista que ha tomado de Apollinaire los esquemas formales y la afición al caligrama.

Mozo de espíritu es el señor Bedoya, y quizá, mejor enterado, se pase al bando ultraísta, pues tiene humor y bríos para ello, ya que nosotros no estamos todavía convencidos de que las grasas amarillas y las telarañas le cubran el corazón, como él mismo afirma en su citado poema - curiosísimo por ciertoy titulado "Psicosis de las secreciones internas".

De buena fe le invito a pasar al bando prometedor y espléndido, y en prueba de mi sinceridad quiero dejar de manifiesto que aun después de haberse chungueado de lo lindo de los revolucionarios de Parisiana, yo, como abogado asesor de la Gran Compañía Anónima del Ultra, no he caído en la tentación de pretender tomarle el pelo.

Mauricio Bacarisse 
En España, núm. 301, Madrid, 5 de febrero I921, páginas II $y$ I 2.

\section{MANIFIESTO DADA}

Paris, 12 enero 1921

Le cubisme construit une cathédrale en pâté de foie artistique Que fait DADA?

l'expressionnisme empoisonne les sardines artistiques

Que fait DADA?

le simultanéisme en est encore à sa première communion artistique

Que fait DADA?

le futurisme veut monter dans un lyrisme + ascenseur artistique

Que fait DADA?

l'unanimisme embrasse le toutisme et pêche à la ligne artistique Que fait DADA?

le néo-classicisme découvre les bienfaits de l'art artistique Que fait DADA? le paroxysme fait le trust de tous les fromages artistiques Que fait DADA? l'ultraïsme recommande le mélange de ces 7 choses artistiques Que fait DADA? le créacionisme le vorticisme l'imagisme proposent aussi quelques recettes artistiques

Que fait DADA?

Que fait DADA?

50 francs de récompense à celui qui trouve le moyen de nous expliquer

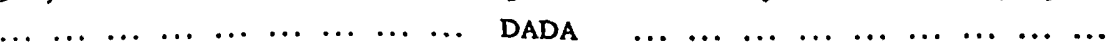




\section{PROCLAMA}

NAIPES Barajando un mazo de cartas se puede conseguir I que vayan saliendo en un enfilamiento más o Filosofía menos simétrico. Claro que las combinaciones así hacederas son limitadas $i$ de humilde interés. Pero si en vež de manipular naipes, se manipularan palabras, palabras imponentes $i$ estupendas, palabras con entorchados $i$ aureolas, entonces ya cambia diametralmente el asunto.

En forma más enrevesada i difícil, se intenta hasta explicar la vida mediante esos dibujos, $i$ al barajador lo rotulamos filósofo. Para que merezca tal nombre, la tradición le fuerza a escamotear todas las facetas de la existencia menos una sola, sobre la cual asienta las demás, i a decir que lo único verdadero son los átomos o la energía o cualquier otra cosa...

¡ Como si la realidad que nos estruja entrañablemente, hubiera menester muletas o explicaciones!

SENTIMENTA- En su forma más evidente y automática, el LISMO PREVISTO juego de entrelazar palabras campea en esa entablillada nadería que es la literatura actual. Los poetas sólo se ocupan de cambiar de sitio los cachivaches ornamentales que los rubenianos heredaron de Góngora - las rosas, los cisnes, los faunos, los dioses griegos, los paisajes ecuánimes i enjardinados- $i$ engarzar millonariamente los flojos adjetivos inefable, divino, azul, misterioso. ¡ Cuánta socarronería i cuánta mentira en ese manosear de ineficaces $i$ desdibujadas palabras, cuánto miedo altanero de adentrarse verdaderamente en las cosas, cuánta impotencia en esa vanagloria de símbolos ajenos! Mientras tanto los demás líricos, aquellos que no ostentan el tatuaje azul rubeniano, ejercen un anecdotismo gárrulo, i fomentan penas rimables que barnizadas de visualidades oportunas venderán 
después con un gesto de amaestrada sencillez i de espontaneidad prevista.

ANQUILOSAMIENTO DE LO

LIBRE

$Y$ unos $\mathrm{i}$ otros señoritos de la cultura latina, gariteros de su alma, se pedestalizan sobre las marmóreas leyes estéticas para dignificar ejercicio tan lamentable. Todos quieren realizar obras apelmazadas i perennes. Todos viven en su autobiografía, todos creen en su personalidad, esa mezcolanza de percepciones entreveradas de salpicaduras de citas, de admiraciones provocadas i puntiaguda lirastenia. Todos tienden a la enciclopedia, a los aniversarios $i$ a los volúmenes tupidos.

El concepto histórico de la vida muerde sus horas. En vez de concederle a cada instante su carácter suficiente i total, los colocan en gerarquías (sic) prolijas. Escriben dramas i novelas abarrotadas de encrucijadas espirituales, de gestos culminantes i de apoteosis donde se remansa definitivamente el vivir. Han inventado ese andamiaje literario - la estética - según la cual hay que preparar las situaciones $i$ empalmar las imágenes, $i$ que convierte lo que debiera ser ágil $\mathrm{i}$ brincador en un esfuerzo indigno $\mathrm{i}$ trabajoso. Idiotez que les hace urdir un soneto para colocar una línea, $\mathrm{i}$ decir en doscientas páginas lo cabedero en dos renglones. (Desde ya puede asegurarse que la novela esa cosa maciza engendrada por la superstición del yo va a desaparecer, como ha sucedido con la epopeya i otras categorías dilatadas.)

U

Nosotros los ultraístas -en esta época de mercachi-

L

T

R

A fles que exhiben corazones disecados i plasman el rostro en carnavales de muecas- queremos desanquilosar el arte. Lícito i envidiable como cualquier. otro placer es el que motivan las palabras eficazmente trabadas, mas hai que convenir en lo absurdo de honrar los que le venden, traficando con flacas ñoñerías $i$ trampas antiquísimas. Nuestro arte quiere superar esas martingalas de 
siempre i descubrir facetas insospechadas al mundo. Hemos sintetizado la poesía en su elemento primordial: la metáfora, a la que concedemos una máxima independencia, más allá de los jueguitos de aquellos que comparan entre sí cosas de forma semejante, equiparando con un circo a la luna. Cada verso de nuestros poemas posee su vida individual $i$ representa una visión inédita. El Ultraísmo propende así a la formación de una mitología emocional i variable. Sus versos que excluyen la palabrería $\mathrm{i}$ las victorias baratas conseguidas mediante el despilfarro de palabras exóticas, tienen la contextura decisiva de los marconigramas.

LATIGUillo Hemos lanzado PRISMA para democratizar esas normas.

Hemos embanderado de poemas las calles, hemos iluminado con lámparas verbales vuestro camino, hemos ceñido vuestros muros con enredaderas de versos: Que ellos izados como gritos, vivan la momentánea eternidad de todas las cosas, i sea comparable su belleza dadivosa, $i$ transitoria, a la de un jardín vislumbrado a la música desparramada por una abierta ventana y que colma todo el paisaje.

\author{
JORGE LUIS BORGES \\ GuILlERMo JuAN \\ EdUARDo González LANUZa \\ GUILLERMO DE TORRE.
}

En Ultra, núm. 21, Madrid, I enero 1922.

\title{
AL MARGEN DE LA MODERNA LfRICA
}

Para el hombre, y más aún para el adolescente, sobre cuyas espaldas descansa todo lo que posee el orbe de arrogante y de 
audaz, un nuevo poema, una novela nueva, puede ser una Atlántida, una íntima y estupenda aventura.

Mas la potencia de admirar que hay en nosotros es limitada $y$, agotados los primeros hallazgos, la ley de lasitud nos impone una concepción rígida del arte, hecha de normas inflexibles entre las cuales queremos aprisionar todas las emociones y toda la belleza que han sentido o sentirán jamás los otros hombres. Para la crítica existente, estas normas son hoy la limpidez y la armonía. En todos los países donde han surgido las modernas tendencias, en Bohemia, en Francia, en Alemania y en España, la crítica las ha sacrificado sobre la vieja cruz de claridad y de euritmia. No han advertido en la labor ultraísta más que los barroquismos de la forma, sin inquietarse del espíritu, del nuevo ángulo de visión que la subraya.

Este ángulo de visión es diametralmente diferente del suyo. Por eso, toda advertencia cauta, toda burla, todo mohín de desdén basados en los viejos idearios, no muestran más que una total incomprensión del verdadero espíritu del ultra.

Intentaré una exégesis. Es posible que muchos ultraístas hállense desacordes conmigo, por tratarse de un arte que traduce impresiones esencialmente individuales, que abandona la grey y busca al individuo.

Las palabras que siguen quieren únicamente ser la expresión de una actitud ante el ultra. No aspiran a un valor objetivo.

El cristianismo y aun el paganismo se basaron sobre una concepción de la vida esencialmente estática. Por eso, mientras las almas fueron cristianas o paganas, el arte pudo buscar la euritmia, la arquitectura, lenta y segura. Hoy triunfa la concepción dinámica del kosmos que proclamara Spencer y miramos la vida, no ya como algo terminado, sino como un proteico devenir, como una rauda carnavalesca teoría hecha de sufrimientos y de goces. Como un febril frondoso rojo aquelarre ante el blanco terror de las estrellas... El ultraísmo es la 
expresión recién redimida del transformismo en literatura. Esa floración brusca de metáforas que en muchas obras creacionistas abruma a los profanos, se justifica así plenamente y representa el esfuerzo del poeta para expresar la milenaria juventud de la vida que, como él, se devora, surge y renace en cada segundo.

Verdad que hemos llegado tarde también... Miles de otros artistas han pulsado las cuerdas del vivir. Entre el mundo externo y nosotros, entre nuestras emociones más íntimas y nuestro propio yo, los fenecidos siglos han elevado espesos bardales. Se nos ha querido imponer la obsesión de un eterno y mustio universo, de ramaje agobiado bajo las grises telarañas y larvas de pretéritos simbolos. Y nosotros queremos descubrir la vida. Queremos ver con ojos nuevos. Por eso olvidamos la fastuosa fantasmagoría mitológica, que en toda hembra lúbrica quiere visualizar una faunesa y ante las formidables selvas del mar, inevitablemente nos sugiere, con livida sonrisa encubridora, la visión lamentable de Afrodita surgiendo de un Mediterráneo de añil ante un coro de obligados tritones...

La miel de la añoranza no nos deleita y quisiéramos ver todas las cosas en una primicial floración. Y al errar por esta única noche deslumbrada, cuyos dioses magníficos son los augustos reverberos de luces áureas, semejantes a genios salomónicos, prisioneros en copas de cristal, quisiéramos sentir que todo en ella es nuevo y que esa luna que surge tras un azul edificio no es la circular eterna palestra sobre la cual los muertos han hecho tantos ejercicios de retórica, sino una luna nueva, virginal y auroralmenté nueva.

Aun lo trivial como esas vividas naranjas, auroras que en fervorosas, lujuriosas piras, incendian los claustrales mercados. es también único, como única es la estremante (sic) noche deslumbrada, atónita de azul, como una gran montaña con surtidores de astros y selvas claras de constelaciones... 
El ultraísmo no es quizás otra cosa que la espléndida síntesis de la literatura antigua, que la última piedra redondeando su milenaria fábrica. Esa premisa tan fecunda que considera las palabras no como puentes para las ideas, sino como fines en sí, halla en él su apoteosis.

Tal vez esta verdad no sea absoluta pero por un instante al menos es sorprendente ver en las tendencias novísimas, algo así como el divino crepúsculo, como la última roja floración, como el canto del cisne de la retórica...

JORGE LUIS BORGES

En Grecia, Sevilla, núm. XXXIX, 3 I enero 1920, páginas 15 y siguientes.

\section{NON SERVIAM}

Y he aquí que una buena mañana, después de una noche de preciosos sueños y delicadas pesadillas, el poeta se levanta y grita a la madre Natura: Non serviam.

Con toda la fuerza de sus pulmones, un eco traductor $y$ optimista repite en las lejanías: "No te serviré".

La madre Natura iba ya a fulminar al joven poeta rebelde. cuando éste, quitándose el sombrero y haciendo un gracioso gesto, exclamó: "Eres una viejecita encantadora".

Ese non serviam quedó grabado en una mañana de la historia del mundo. No era un grito caprichoso, no era un acto de rebeldía superficial. Era el resultado de toda una evolución. la suma de múltiples experiencias.

El poeta, en plena conciencia de su pasado y de su futuro, lanzaba al mundo la declaración de su independencia frente a la naturaleza.

Ya no quiere servirla más en calidad de esclavo.

El poeta dice a sus hermanos: "Hasta ahora no hemos hecho otra cosa que imitar al mundo en sus aspectos, no hemos creado nada. ¿Qué ha salido de nosotros que no estuviera 
antes parado ante nosotros, rodeando nuestros ojos, desafiando nuestros pies o nuestras manos?".

"Hemos cantado a la naturaleza (cosa que a ella bien poco le importa). Nunca hemos creado realidades propias, como ella lo hace o lo hizo en tiempos pasados, cuando era joven y llena de impulsos creadores."

"Hemos aceptado, sin mayor reflexión, el hecho de que no puede haber otras realidades que las que nos rodean, y no hemos pensado que nosotros también podemos crear realidades en un mundo nuestro, en un mundo que espera su fauna y su flora propias. Flora y fauna que sólo el poeta puede crear, por ese don especial que le dio la misma Madre Naturaleza a él y únicamente a él."

Non serviam. No he de ser tu esclavo, madre Natura; seré tu amo. Te servirás de mí; está bien. No quiero y no puedo evitarlo: pero yo también me serviré de ti. Yo tendré mis árboles que no serán como los tuyos, tendré mis montañas, tendré mis ríos y mis mares, tendré mi cielo y mis estrellas.

$Y$ ya no podrás decirme: "Ese árbol está mal, no me gusta ese cielo..., los míos son mejores".

Yo te responderé que mis cielos y mis árboles son los míos y no los tuyos y que no tienen por qué parecerse. Ya no podrás aplastar a nadie con tus pretensiones exageradas de vieja chocha y regalona. Ya nos escapamos de tu trampa.

Adiós, viejecita encantadora ; adiós, madre y madrastra, no reniego ni te maldigo por los años de esclavitud a tu servicio. Ellos fuéron la más preciosa enseñanza. Lo único que deseo es no olvidar nunca tus lecciones, pero ya tengo edad para andar solo por estos mundos. Por los tuyos y por los míos.

Una nueva era comienza. Al abrir sus puertas de jaspe. hinco una rodilla en tierra $y$ te saludo muy respetuosamente.

Vicente Huidobro, en Obras poéticas selectas, Santiago de Chile, 1957, págs. 243 y 244. 


\section{EL CREACIONISMO}

El creacionismo no es una escuela que yo haya querido imponer a alguien, el creacionismo es una teoría estética general que empecé a elaborar hacia 1912 , y cuyos tanteos y primeros pasos los hallaréis en mis libros y artículos escritos mucho antes de mi primer viaje a París.

En el número 5 de la revista chilena Musa Joven, yo decía :

El reinado de la literatura terminó. El siglo veinte verá nacer el reinado de la poesía en el verdadero sentido de la palabra, es decir, en el de creación, como la llamaron los griegos, aunque jamás lograron realizar su definición.

Más tarde, hacia IgI3 ó I9I4, yo repetía casi igual cosa en una pequeña entrevista aparecida en la revista Ideales, entrevista que encabezaba mis poemas. También en mi libro $\mathrm{Pa}$ sando y Pasando, aparecido en diciembre de 19.13, digo en la página 270 que lo único que debe interesar a los poetas es el "acto de la creación", y oponía a cada instante este acto de creación a los comentarios y a la poesía alrededor de. La cosa. creada contra la cosa cantada.

En mi poema Adán, que escribí durante las vacaciones de I914 y que fue publicado en 1916, encontraréis estas frases de Emerson en el Prefacio, donde se habla de la constitución del. poema :

Un pensamiento tan vivo que, como el espíritu de una planta o de un animal, tiene una arquitectura propia, adorna la naturaleza con una cosa nueva. 
Pero fue en el Ateneo de Buenos Aires, en una conferencia que di en junio de rgr6. donde expuse plenamente la teoría. Fue allí donde se me bautizó como creacionista por haber dicho en mi conferencia que ia primera condición del poeta es crear. la segunda crear, y la tercera, crear.

Recuerdo que el profesor argentino José Ingenieros, que era uno de los asistentes, me dijo durante la comida a que me invitó con algunos amigos después de la conferencia: "Su sue. ño de una poesía inventada en cada una de sus partes por los poetas me parece irrealizable, aunque usted lo haya expuesto en forma muy clara e incluso muy científica".

Casi la misma opinión la tienen otros filósofos en Alemania y dondequiera yo haya explicado las mismas teorías. "Es hermoso, pero irrealizable."

¿Y por qué habrá de ser irrealizable?

Respondo ahora con las mismas frases con que acabé mi conferencia dada ante el grupo de Estudios Filosóficos y Científicos del doctor Allendy, en París, en enero de 1922 :

Si el hombre ha sometido para sí a los tres reinos de la naturaleza, el reino mineral, el vegetal y el animal, ¿por qué razón no podrá agregar a los reinos del universo su propio reino, el reino de sus creaciones?

El hombre ya ha inventado toda una fauna nueva que anda, vuela, nada, y llena la tierra, el espacio y los mares con sus galopes desenfrenados, con sus gritos y sus gemidos.

Lo realizado en la mecánica también se ha hecho en la poesía. Os diré qué entiendo por poema creado. Es un poema en el que cada parte constitutiva, y todo el conjunto, muestra un hecho nuevo, independiente del mundo externo, desligado de cualquiera otra realidad que no sea la propia, pues toma su puesto en el mundo como un fenómeno singular, aparte y distinto de los demás fenómenos. 
Dicho poema es algo que no puede existir sino en la cabeza del poeta. Y no es hermoso porque recuerde algo, no es hermoso porque nos recuerde cosas vistas, a su vez hermosas, ni porque describa hermosas cosas que podamos llegar a ver. Es hermoso en sí y no admite términos de comparación. $Y$ tampoco puede concebírselo fuera del libro.

Nada se le parece en el mundo externo; hace real lo que no existe, es decir, se hace realidad a sí mismo. Crea lo maravilloso y le da vida propia. Crea situaciones extraordinarias que jamás podrán existir en el mundo objetivo, por lo que habrán de existir en el poema para que existan en alguna parte.

Cuando escribo: "El pájaro anida en el arco-iris", os presento un hecho nuevo, algo que jamás habéis visto, que jamás veréis, y que sin embargo, os gustaría mucho ver.

Un poeta debe decir aquellas cosas que nunca se dirian sin él.

Los poemas creados adquieren proporciones cosmogónicas; os dan a cada instante el verdadero sublime, este sublime del que los textos nos presentan ejemplos tan poco convincentes. Y no se trata del sublime excitante y grandioso, sino de un sublime sin pretensión, sin terror, que no desea agobiar ni aplastar al lector: un sublime de bolsillo.

El poema creacionista se compone de imágenes creadas, de situaciones creadas, de conceptos creados; no escatima ningún elemento de la poesía tradicional, salvo que en él dichos elementos son integramente inventados, sin preocuparse en absoluto de la realidad ni de la veracidad anteriores al acto de realización.

Así, cuando escribo :

El océano se deshace

Agitado por el viento de los pescadores que silban

presento una descripción creada; cuando digo: "Los lingotes de la tempestad", os presento una imagen pura creada, y cuan- 
do os digo: "Ella era tan hermosa que no podía hablar", o bien: "La noche está de sombrero", os presento un concepto creado.

En Tristan Tzara encuentro poemas admirables que están muy cerca de la más estricta concepción creacionista. Aunque en él la creación es generalmente más formal que fundamental. Pero el hombre que ha escrito los siguientes versos es, sin la scmbra de una duda, un poeta:

En porcelaine la chanson pensée, je suis fatigué - la chanson des reines l'arbre crève de la nourriture comme une lampe.

Je pleure vouloir se lever plus haut que le jet d'eau serpente au ciel car il n'existe plus la gravité terrestre à l'école et dans le cerveau.

Quand le poisson rame

le discours du lac

quand il joue la gamme

la promenade des dames, etc. ${ }^{2}$.

A veces, Francis Picabia nos abre en sus poemas ventanas sobre lo insospechado, probándonos que no sólo es pintor:

\author{
Enchainé sur l'avenir de l'horloge \\ des récreations \\ dans u'n empire missel;
}

1 En porcelana la canción pensada, estoy fatigado - la canción de las reinas el árbol revienta de alimento como una lámpara.

Lloro querer alzarse más alto que el juego de agua serpiente en el cielo, pues ya no existe la gravedad terrestre en la escuela y en el cerebro.

Cuando el pez rema

el discurso del lago

cuando toca el diapasón

el paseo de las damas, etc.

EL ULTRAISmo. - I4 
Le jour épuis. d'un court instant

parcimonieux

échappe à la sagacité du lecteur

d'esprit.

Les jeunes femmes compagnes du fleuve

logique viennent comme une tache sur l'eau

pour gagner un monstre enfumé

d'amis aimables

dans l'ordre du suicide enragé.

Emporter une histoire pour deux

à force de joie dans la chevelure

des syllabes ${ }^{2}$.

También Georges Ribémont Dessaignes tiene versos que nos sacan de lo habitual:

Regarder par la prunelle de sa maitresse afin de voir à l'intérieur ${ }^{3}$.

Encadenado sobre el porvenir del reloj

diversiones

en un imperio misal;

El día agotado por un corto instante parsimonioso

escapa a la sagacidad del lector fino.

Las jóvenes mujeres compañeras del rio lógico llegan como una mancha sobre el agua para ganar un monstruo ahumado

de amigos amables

en la orden del suicida enrabiado.

Llevar una historia para dos

a fuerza de alegria en la cabellera de las sílabas.

Mirar por la pupila de su amante para ver qué hay dentro. 
Y Paul Eluard nos hace a menudo temblar como un surtidor que nos golpeara la espina dorsal:

Il y a des femmes dont les yeux sont comme des morceaux de sucre il $y$ a des femmes graves comme les mouvements de l'amour qu'on [ne surprend pas, d'autres, comme le ciel à la veille du vent Le soir trainait des hirondelles. Les hibous partageaient le soleil et pesaient sur la terre ${ }^{4}$.

Los dos poetas creacionistas españoles, Juan Larrea y $\mathrm{Ge}$ rardo Diego, han dado sendas pruebas de su talento. Cuando Gerardo Diego escribe:

Al silbar tu cabeza se desinfla

o bien :

La lluvia tiembla como un cordero

o esto otro :

\section{Una paloma despega del cielo}

nos da una sensación poética muy pura. Igual cosa sucede con Juan Larrea cuando dice:

Un pájaro cambia el tiempo

o bien :

Lechos de ladrillos entre los sonidos

Y aún esto otro:

Tu recuerdo se aleja según la dirección del viento.

4 Hay mijeres cuyos ojos son como pedazos de azúcar hay mujeres serias como los movimientos del amor que uno no sorprende, otras como el cielo en visperas de viento.

La tarde arrastraba golondrinas. Los buhos dividian el sol y pesaban sobre la tierra. 
Ambos poetas han probado a los españoles escépticos hasta qué grado de emoción puede llegar lo inhabitual, demostrando todo lo que de serio contiene la teoría creacionista. Nunca han hecho burlarse (como aquellos pobres ultraístas) a las personas de espíritu realmente superior.

Si para los poetas creacionistas lo que importa es presentar un hecho nuevo, la poesía creacionista se hace traducible y universal, pues los hechos nuevos permanecen idénticos en todas las lenguas.

Es difícil y hasta imposible traducir una poesía en la que domina la importancia de otros elementos. No podéis traducir la música de las palabras, los ritmos de los versos que varían de una lengua a otra; pero cuando la importancia del poema reside ante todo en el objeto creado, aquél no pierde en la traducción nada de su valor esencial. De.este modo, si digo en francés :

\section{La nuit vient des yeux d'autrui}

o si digo en español:

La noche viene de los ojos ajenos

o en inglés:

Night comes from other eyes

el efecto es siempre el mismo y los detalles lingiiísticos secundarios. La poesía creacionista adquiere proporciones internacionales, pasa a ser la Poesía, y se hace accesible a todos los pueblos y razas, como la pintura, la música o la escultura.

En la época de la revista Nord-Sud, de la que fui uno de los fundadores, todos teníamos más o menos la misma orien- 
tación en nuestras búsquedas, pero en el fondo estábamos bastante lejos unos de otros.

Mientras otros hacían buhardas ovaladas, yo hacia horizontes cuadrados. He aquí la diferencia expresada en dos palabras. Como todas las buhardas son ovaladas, la poesía sigue siendo realista. Como los horizontes no son cuadrados, el autor muestra algo creado por él.

Cuando apareció Horizon carré, he aquí cómo expliqué dicho título en una carta al crítico y amigo Thomas Chazal:

Horizonte cuadrado. Un hecho nuevo inventado por mí, creado por mí, que no podría existir sin mi. Deseo, mi querido amigo, englobar en este título toda mi estética, la que $\mathrm{Vd}$. conoce desde hace algún tiempo.

Este título explica la base de mi teoría poética. Ha condensado en sí la esencia de mis principios.

1. Humanizar las cosas. Todo lo que pasa a través del organismo del poeta debe coger la mayor cantidad de su calor. Aquí algo vasto, enorme, como el horizonte, se humaniza, se hace íntimo, filial gracias al adjetivo cuadrado. El infinito anida en nuestro corazón.

2. Lo vago se precisa. Al cerrar las ventanas de nuestra alma, lo que podía escapar y gasificarse, deshilacharse, queda encerrado y se solidifica.

3. Lo abstracto se hace concreto y lo concreto abstracto. Es decir, el equilibrio perfecto, pues si lo abstracto tendiera más hacia lo abstracto, se desharía en sus manos o se filtraría por entre sus dedos. Y si Vd. concretiza aún más lo concreto, éste le servirá para beber vino o amoblar su casa, pero jamás para amoblar su alma.

$44^{\circ}$ Lo que es demasiado poético para ser creado se transforma en algo creado al cambiar su valor usual, ya que si el horizonte era poético en sí, si el horizonte era poesía 
en la vida, al calificársele de cuadrado acaba siendo poesia en el arte. De poesía muerta pasa a ser poesía viva.

Las pocas palabras que explican mi concepto de la poesía, en la primera página del libro de que hablamos, os dirán qué quería hacer en aquellos poemas. Decía:

Crear un poema sacando de la vida sus motivos y transformándolos para darle una vida nueva $e$ independiente.

Nada de anecdótico ni de descriptivo. La emoción debe nacer de la sola virtud creadora.

Hacer un poema como la naturaleza hace un árbol.

En el fondo, era exactamente mi concepción de antes de mi llegada a París: la de aquel acto de creación pura que hallaréis, como una verdadera obsesión, en cualquier parte de mi obra a partir de rgi2. $Y$ aún sigue siendo mi concepción de la poesía. El poema creado en todas sus partes, como un objeto nuevo.

Debo repetir aquí el axioma que presenté en mi conferencia del Ateneo de Madrid, en I921, y últimamente en París, en mi conferencia de la Sorbona, axioma que resume mis principios estéticos: "El Arte es una cosa y la Naturaleza otra. Yo amo mucho el Arte y mucho la Naturaleza. Y si aceptáis las representaciones que un hombre hace de la Naturaleza, ello prueba que no amáis ni la Naturaleza ni el Arte".

En dos palabras y para terminar: los creacionistas han sido los primeros poetas que han aportado al arte el poema inventado en todas sus partes por el autor.

He aqui, en estas páginas acerca del creacionismo, mi testamento poético. Lo lego a los poetas del mañana, a los que serán los primeros de esta nueva especie animal, el poeta, de esta nueva especie que habrá de nacer pronto, según creo. Hay signos en el cielo. 
Los casi-poetas de hoy son muy interesantes, pero su interés no me interesa.

El viento vuelve mi flauta hacia el porvenir.

Vicente Huidobro, en Obras poéticas selectas, Santiago de Chile, I957, págs. 267 y sigs. 


\title{
B I B L I O G R A F f A
}

\author{
L I B R O S
}

Alonso, Amado. Materia y forma en poesía, Madrid, Gredos, 1960. Alonso, Dámaso. Ensayos sobre poesía española, Madrid, Revista de Occidente, 1944.

Estudios y ensayos gongorinos, Madrid, Gredos, 1955.

Poetas españoles contemporáneos. Madrid, Gredos, 1958.

ANDERSON IMBERT, ENRIQUE. Historia de la literatura hispanoamericana, México, Fondo de Cultura Económica, 1957.

ANGUITA, EDUARDo. (Ver Vicente Huidobro.)

Antología. - Caballo de Fuego (La poesia del siglo veinte en América y España), Buenos Aires, Ediciones de la revista Caballo de Fuego, 1952.

ANTOLOcía de la poesía argentina moderna (1896-1930) con notas biográficas y bibliográficas de Julio Noé. 2." ed. Buenos Aires, El Ateneo, 1931.

ANTOLocía del surrealismo español. (José Albi-Joan Fuster.) Revista Verbo, Alicante, 1952, núms. 23-24-25.

Apollinaire, Guillaume. Calligrammes. Cinquante et unième édition, Paris, Gallimard, 1958.

Estudio preliminar y páginas escogidas por Guillermo de Torre.

(Traducción... por M. Mir), Buenos Aires, Poseidón, 1946.

astrana Marín, Luis. Gente, gentecilla y gentuza. Críticas y sátiras,

Madrid, G. Hernández (s. f.). 
Bajarlía, JuAN JACOBO. Literatura de vanguardia. Del "Ulises" de Joyce y las escuelas poéticas. Buenos Aires, Araujo, 1946. El vanguardismo poético en Anérica y España. Buenos Aires, $\mathrm{Pe}$ rrot, I957.

BompIanI-GonZÁl.ez PORTO. Diccionario literario. Tomo I. Movimientos espirituales. Barcelona, 1959.

BORgES, JORge LuIs. Inquisiciones. Buenos Aires, Proa, 1925.

El Hacedor. Buenos Aires, Emecé, i960.

Poemas. 1923-1953, Buenos Aires, Emecé, 1954.

Bousoño, Carlos. Teoria de la expresión poética. Madrid, Gredos, 1956.

La poesía de Vicente Aleixandre. Madrid, Gredos, 1956.

BOUvIER, ÉMILE. Initiation à la littérature d'aujourd'hui. Paris, La Renaissance du Livre, 1929.

Cansinos-Asséns, Rafael. El divino fracaso. Madrid, S. L., de Artes Gráficas (s. f.).

La huelga de los poetas (Novela). Madrid, Mundo Latino (1921).

El movimiento V. P. (Novela). Madrid, Mundo Latino (s. f.).

La nueva literatura. Tomo III : La evolución de la poesía (rgr71927). Madrid, Editorial Páez, 1927.

Poetas y prosistas del 900 (España y América). Madrid (Juan PueYo), Igrg.

Cernuda, Luis. Estudios sobre poesía española contemporánea. Madrid, Guadarrama, 1957.

Cirlot, Juan-Eduardo. Diccionario de Ismos. Barcelona, Argos, 1949. Cossío, José María DE. Prólogo a Poesías de Fernando Villalón. Madrid, Ed. Hispánica, I 944.

Chabás y MARTí, JuAN. Espejos. Verso. 1919-1920. Madrid, Galatea, I 921.

Literatura española contemporánea. 1898-1950. La Habana, Cultural, 1952.

Díaz-Plaja, Guillermo. Historia de la poesía lirica española. 2. edic., Labor, Barcelona, 1948.

Diego, Gerardo. ... Antología ... Prólogo y edición del autor. Salamanca, Anaya (1 958).

Evasión. Lírica Hispánica, núms. I 89 y I90, Caracas, nov. y dic. 1958. 
Imagen. Poenras (1918-1921). Madrid, Gráficas Ambos Mundos (1922).

Manual de espumas. Madrid (Ciudad Lineal), 1924.

Poesia española contemporánea. Antologia, rgor-1934. Madrid. Taurus, 1959.

Primera Antologia de sus versos. 2. ${ }^{a}$ edic., Madrid, Espasa-Calpe, I942.

Díez-Echarri, E. y Roca Franquesa, J. M. Historia de la literatura española e hispanoamericana. Aguilar, Madrid, 1960.

Epstein, Jean. La poésie d'aujourd'hui. Paris, Audin et Cie, $192 \mathrm{I}$. ESQUERRA, RAMón. Vocabulario literario. Barcelona, Apolo, 1938. FernándeZ-Moreno, CÉSAR. Esquema de Borges. Buenos Aires, Perrot, 1957.

La poesia argentina de vanguardia, en Historia de la literatura argentina, dirigida por Rafael Alberto Arrieta, Buenos Aires, Peuser, I959, tomo IV.

Forcada-Cabanellas. De la vida literaria. Rosario (Argentina), 1941. FRIEDRICH, Hugo. Estructura de la lírica modema. De Baudelaire hasta nuestros días. Traducción española de Juan Petit, Barcelona, Seix Barral, 1959.

GHIANo, Juan Carlos. La puesía argentina del siglo $X X$. MéxicoBuenos Aires, Fondo de Cultura Económica, 1957.

Gómez de la Serna, Ramón. Automoribundia (1888-1948). Buenos Aires, Ed. Sudamericana, 1948.

El concepto de la nueva literatura. Profesión de fe y escepticismo, leída y presentada a la discusión en el Ateneo... de Madrid, Madrid (s. f.).

El libro mudo (Secretos). Por -. Prólogo de Tristán (seud.) (Madrid, s. i.) (s. f. [1910]).

Greguerias selectas. Madrid, Saturnino Calleja, 1919.

Greguerias, 1940-1943. 3." edición aumentada y seleccionada. Buenos Aires, Espasa-Calpe, 1943.

Greguerias. Selección 1910-1960. Sexta edición, Madrid, EspasaCalpe, 1960.

Ismos. Madrid, Espasa-Calpe, 1931.

Mis mejores páginas literarias. Madrid, Gredos, 1957.

Morbideces. Madrid, I908. 
Muestrario -. Madrid-Cartagena (s. f., ¿'1918?).

Norah Borges. Buenos Aires, Losada, 1945.

Nuevas páginas de mi vida (Lo que no dije de mi automoribundia). Alcoy-Marfil (Valencia-Tip. Artística), 1957.

Pombo (La Sagrada Cripta de Pombo). Madrid, G. Hernández y Galo Sáez, 1918, 2 vols.".

Nuevos retratos contemporáneos. Buenos Aires, Ed. Sudamericana, 1945.

Retratos contemporáneos. Buenos Aires, Sudamericana, 194I.

Tapices (S. 1. ni f. [1913]).

González-Ruano, César. Antología de poetas españoles contemporáneos en la lengua castellana. Barcelona, Gustavo Gili, 1946.

Poesía (1924-1944) (Barcelona), Montaner y Simón, i 944.

Mi medio siglo se confiesa a medias. - Memorias. Barcelona, Noguer, 195I.

Siluetas de escritores contemporáneos. Madrid, Editora Nacional, 1949.

GutiéRrez-Gili, JuAn. Surco y estela. Barcelona, Ed. Miguel Casals, 1925.

HatzFeld, Helmut. Bibliografía crítica de la nueva estilistica, aplica da a las literaturas románicas. Madrid, Gredos, 1955.

Henríguez Ureña, Pedro. Las corrientes literarias en la América Hispánica. México, Fondo de Cultura Económica, 1949.

Huidobro, Vicente. Antología. Santiago de Chile, Ziz-Zag, 1945.

Prólogo, selección, traducción y notas por Eduardo Anguita.

Ecisatorial. Madrid, 1918.

Horizon carré. I. ${ }^{a}$ ed., París, Paul Birault, 1917.

Indice de la nueva poesía americana (Prólogo de), Buenos Aires (1926).

Manifestes. Paris, Ed. de la Revue Mondiale, 1925.

Obras poéticas selectas. Selección y prólogo de Hugo Montes, traducción de las obras en francés de José Zañartu. Vol. I, Santiago de Chile, Ed. del Pacífico, 1957.

Poesia y prosa. Antología precedida de un ensayo del creacionismo, por Antonio de Undurraga, un poema de G. Diego e iconografía por Juan Gris, Picasso, etc. Madrid, Aguilar, 1957. 
Poemas árticos. Madrid, 1918.

Saisons choisies (Prólogo). París, Povolozky, 1921.

JACOB, MaX. El cubilete de dados. Versión castellana y prólogo de G. de Torre. Madrid, Velasco Hnos., 1924.

Jiménez, Juan RaMón. Estio (1915), r. a edic., Madrid, Calleja, igr6. Eternidades. Verso (1916-1917). Madrid, Renacimiento, 1931.

Diario de $21 n$ poeta recién casado (1916). Madrid, Fontanet, 1917. Pájinas escojidas. Verso (Selección y nota preliminar de Ricardo Gullón). Madrid, Gredos, $195^{8}$.

Seginda antolojía poética (1898-1918). Madrid, Calpe, 1920.

KAYSER, WOLFANG. Interpretación y análisis de la obra literaria. Madrid, Gredos, 1958.

KonRad, Hedwig. Etude sur la métaphore. Paris, Ed. Librairie-Philo. sophique J. Vrin, 1958.

LAPI, FERNANDO DE. Stma poética (I908-1924). Madrid, Mundo Latino, 1925.

MaCHADO, ANTONIO. "Sobre las imágenes en la lírica (Al margen de un libro de Vicente Huidobro)" y "Sobre el empleo de las imágenes en la lírica", en Obras completas. Madrid, Plenitud, 1957, páginas 1219 y sigs.

MarinetTI, F. T. El Futurismo. Valencia, ¿1912?

Les mots en-liberté futuristes. Milano, Ed. Poesía, I9r9.

Medina, Vicente. En las escuelas. Rosario de Santa Fe, I92I.

Montes, Hugo. Ver V. Huidobro.

Newmark, Maxim. Dictionary of Spanish Literature. Nueva York, I 956.

ONIS, FEDERICO DE. Antología de la poesia española e hispanoamericana. (1882-1932). Madrid, Centro de Estudios Históricos, I934.

ORS, Eugenio D'. El nuevo glosario (5. vol.) : Poussin y el Greco. Madrid (Rafael Caro Raggio), r 1922.

ORTEGA Y GASSET, JOSÉ. La deshumanización del arte (1925), en Obras completas, tomo III (1917-1928). Madrid, Revista de Occidente, 1946 , págs. 351 y sigs.

El tema de nuestro tiempo (1923), en ibid., págs. 14I y sigs.

Ensayo de estética a modo de prólogo, en ibid., T. VI, págs. $247 \mathrm{y}$ siguientes. 
Peña, Manuel de la. El Ultraísmo en España. Avila, Imp. de la Editorial Castellana, 1925.

PICON, GaËTAN. Panorama de las ideas contemporáneas. Trad. Gonzalo Torrente, Madrid, Guadarrama, 1958.

Panorama de la literatura francesa actual. Madrid, Guadarrama, I 958.

PINTO, JUAN. Breviario de la literatura argentina contemporánea (Con una ojeada retrospectiva). Buenos Aires, La Mandrágora, 1958.

Putnam, Samuel. The european caravan. Nueva York, 1931.

Reverdy, Pierre. Antología. Versión libre, selección y notas de Jorge Carrera Andrade. Madrid, CLAN (Artes Gráf. AGA), 1951. Col.: "Cuadernos de Poesía".

Ríos Patrón, José Luis. Jorge Luis Borges. Buenos Aires, La Mandrágora, 1955.

Roca Franquesa, J. M. (Ver Díez-Echarri).

Rodríguez Alcalde, Leopoldo. Vida y sentido de la poesia actual. Madrid, Ed. Nacional, I 956.

Sáinz de Robles, Federico Carlos. Ensayo de un diccionario de literatura. 2." edición, Madrid, Aguilar, 1954-1956.

Los movimientos literarios (Concepto y antología). Madrid, Aguilar. Colección Crisol, I948.

Salinas, Pedro. Literatura española, siglo $\mathcal{X X}$. Segunda edición aumentada, México, Antigua Librería Robledo (Edit. Cultura), 1949. Sánchez, Juan Sebastián. Prismes. Antologia poètica, 1924-1931. Barcelona, Apud auctorem, 1957.

Santos Torroella, Rafael. Medio siglo de publicaciones de poesía en España. Catálogo de Revistas. Madrid, I Congreso de Poesía, 1952.

Souvirón, José María. Antología de poetas españoles contemporáneos. 2." edición. Nascimiento. Santiago de Chile, 1947.

TORRE, Guillermo dE (Ver Apollinaire, G.).

(Ver Jacob, Max).

Literaturas europeas de vanguardia. Madrid, Caro Raggio, 1925. Estudio preliminar a las Poesias completas de Herrera y Reissig. Buenos Aires, Losada, 1942.

Hélices. Poemas (1918-1922). Madrid, Mundo Latino, 1923.

Las metamorfosis de Proteo. Buenos Aires, Losada, 1956. 
Problemática de la literatura. Buenos Aires, Losada, 1951.

Ramón Gómez de la Serna. Antologí. Cincuenta años de literatura. Selección y prólogo de G. de Torre, Buenos Aires, Losada, I955. TORRENTE BALlester, Gonzalo. Panorama de la literatura española contemporánea. Madrid, Guadarrama, 1956.

UndurRaga, ANTONIO. (Ver Vicente Huidobro.)

Valbuena Prat, Ángel. Historia de la literatura española. Tomo II, Barcelona, Gustavo Gili, 1937.

La poesía española contemporánea. Madrid, Compañia Ibero-Americana de Publicaciones, 1930.

VANDO-VILLAR, ISAAC DEL. La sombrilla japonesa. Sevilla, Imp. La Exposición, 1924.

Vignale, Pedro Juan y Tiempo, César. Exposición de la actual poesía argentina. (1922-1927), Buenos Aires, Minerva, s. f.

VIVANCO, LUIS FELIPE. Introducción a la poesía española contemporánea. Madrid, Guadarrama, 1957.

Wellek, René y Warren, Austin. Teoria literaria. Madrid, Gredos, 1959.

\section{A R T I C U L O S}

Abril, ManUel. "Barradas", en Ultra, núm. 2, 10 feb. I921. "Barradas el uruguayo", Alfar, abril 1925, núm. 49, págs. i I a 21. "Sobre la deshumanización del arte", en Cruz y Raya, 15 de mayo de r933, págs. 154 a 163.

AdRIANUS (¿ADRIANO DEL VALLE?). "La fiesta del Ultra", en Grecia, núm. XV, Sevilla, I9I9, págs. ig y 20.

ANónimo: "A través de las nuevas revistas" (Reseñas de Reflector y Ultra), en Cosmópolis, núm. 30, junio 1921, pág. 168.

"Cubismo y algo más", en España, núm. 254, págs. 15-16, 13 de marzo de 1920.

"Un enemigo de DADÁ", en España, núm. 266, págs. 15-16, 5 de junio de I920.

"Futurista, pero no mucho", en España, núm. 277, año VI, 21 de agosto de 1920, pág. ro. 
"Una generación se juzga a sí misma" (encuesta), en Nosotros, núms. 279-280, VIII-IX, 1932, T. LXXV.

"Los jóvenes ultraístas en el viejo Ateneo". El Tiempo, Madrid, I. mayo I921.

"El Movimiento DADÁ". Extractos del Boletin DADÁ, núm. 6. Traducido por César A. Comet, en: Cervantes, julio I920, págs. 93 a 97 .

"Nuestra encuesta sobre la nueva generación literaria", en Nosotros, núms. 168-172, V-IX, 1923. T. XLIV y XLV.

"Nuestras normas", en Mediodía, núm. I, Sevilla, I926, págs. I y siguientes.

"Nuestra Velada", en Ultra, núm. 2, 10 feb. 1921.

"Panorama ultraísta". Grecia. Madrid, 1." agosto 1920.

"Velada ultraísta", en La Tribuna, Madrid, 3 mayo I92I.

"Los ultraístas en el Ateneo", en El Sol, 3 de mayo de ig2r.

Apollinaire, Guillaume. "El espíritu nuevo y los poetas", en Cosmópolis, I, enero 1919, págs. 17 a 28.

ARroyo, CÉSAR E. "La nueva poesía en América. La evolución de un gran poeta", en Cervantes, agosto 1919, págs. I03 a 106.

BaCarisse, Mauricio. "Afirmaciones futuristas", en España, núm. 27ı, 10 de julio de 1920, págs. 14-15.

"Otra vez Herrera y Reissig", en España, núm. 301, 1921, páginas II Y I 2.

Bajarlía, Juan JaCoBo. "Origen del vanguardismo en la poesía castellana", en Caballo de Fuego, núm. 7. Buenos Aires, julio 195I.

Beauduin, N. "La nouvelle école ultraïste", en La Vie des Lettres, París, enero 1921.

BedoyA, M. A. "Del Madrid funambulesco. En plena apoteosis del disparate. Los ultraístas dieron anoche una función de gala", en La Voz, Madrid, 29 de enero de 1921 , pág. 2.

Benlliure y Tuero, Mariano. "Los Bombos", en la libertad, Madrid, ...

Borges, Jorge LuIS. "Antología expresionista", en Cervantes, Madrid, octubre 1920, págs. 100 a I 12.

"Examen de metáforas", en Alfar, núm. 40, mayo 1924, págs. I I $y \mathrm{I} 2$. 
"Examen de metáforas", Parte 2.", en Alfar, núm. 41, junio-julio 1924 , págs. 4 y 5 .

"Lírica expresionista", en Grecia, núm. L, I. nov. 1920, págs. 1o Y II.

"La metáfora", en Cosmópolis, núm. 35, noviembre 1921, páginas 395 a 402 .

"Ultraísmo", en Nosotros, XXXIX, núm. 151, Buenos Aires, diciembre 1921, págs. 466 a 471 .

"Ultraísmo", en El Diario Español, Buenos Aires, 23 octubre 1921. "Vertical", en Reflector, núm. I, Madrid, diciembre 1920.

Borges, Jorge luis; Juan, Guillermo; González lanuza, EduarDO; TORRE, GUillermo DE. "Proclama ultraísta", publicada en el núm. I de la revista mural Prisma y reproducida en Ultra, número 21, Madrid, $10^{\circ}$ enero 1922.

Cansinos-Asséns, Rafael. "El Arte Nuevo. Sus manifestaciones entre nosotros", en Cosmópolis, I, núm. 2, 1919, págs. 262 y sigs. "Instrucciones para leer a los poetas ultraistas", en Grecia, número XLI, año Ill, 1920, págs. I y 2.

"Liminar", en Cervantes, enero 1919, págs. I y sigs.

"La novísima poesía. Antología lírica" (G. Apollinaire, P. Valéry, A. Salmon, P. Reverdy, L. Aragon, Max Jacob, T. Tzara), en Cervantes, mayo 1919, págs. 90 a 105.

"La nueva lírica", en Cosmópolis, III, núm. V, mayo de 19r9, págs. 72 a 80.

"Para los Poemas de los pinos, de Xavier Bóveda", en Grecia, núm. XXV, año II, 1919, págs. II y 12.

"Los poetas del Ultra", en Cervantes, junio 1919, págs. 84 a 86.

"Vertical. Manifiesto ultraísta, por Guillermo de Torre", en Cervantes, Madrid, diciembre 1920 , págs. II 5 a 121 .

"Vicente Huidobro y el Creacionismo", en Cosmópolis, núm. I, 1919, pág. 68.

Carilla, Emillo. "El Vanguardismo en la Argentina", en Nordeste, núm. I, 1960, págs. 51 a 83.

CASsou, Jran. "Lettres espagnoles", en Mercure de France, Paris, i5 enero 1921 .

COMET, César. "Una época de arte puro", en Cervantes, abril I9ig, págs. 86 y sigs.

EL ULT́raísmo. - I5 
Correa-Calderón. "Exégesis de la lírica del más allá", en Cervantes, feb. I920, págs. I 00 a I IO.

Cruzado, Clemente. "La nueva literatura", en La Tribuna, Ciudad Real, 18 setiembre 1920.

Cubero, Antonio M. "Literatura ultraísta", en Cosmópolis, núm. i 2, dic. de 1919, pág. 632 .

"Notas bibliográficas: Pombo y Muestrario de Ramón Gómez de la Serna", en Grecia, núm. XXVI, año II, Sevilla, 1919, pág. 14. "Propósito para los hermanos del Ultra", en Cervantes, nov. I9I9, págs. 132 a 138 .

"Los únicos de nuestra atención", en Grecia, núm. XXIV, año II, I9I9, pág. I 4 .

Chabás y Martí, Juan. "Orientaciones de la post-guerra", en Cervantes, enero I919. págs. 154 y sigs.

Diego, Gerardo. "Adriano del Valle", en Poesía Española. Segunda época, núm. 63, octubre 1957, págs. 13 a 15.

"Dos monólogos", en Alfar, febrero 1925, núm. 47, pág. 7.

"Gerardo Diego nos habla de su poesía", en Verbo, núms. 19-20, octubre-diciembre de 1950, pág. 13.

"José de Ciria y Escalante. Madrid 1924", en Alfar, febrero 1925. núm. 47, pág. 3I.

"La nueva arte poética española", en Sintesis, Buenos $A_{1}$ es, 1929. II, núm. 20.

"Minuta y poesía", en Alfar, La Coruña, núm. 45, dic. de 1924, pág. 3 .

"Posibilidades creacionistas", en Cervantes, octubre 1919, págs. 23 a 28.

"Retórica y poética", en Revista de Occidente, nov, de 1924, número XVII, págs. 280 a 286.

Díez-Canedo, EnRiQue. "El Futurismo", en España, 28 de febrero de 1918.

"Guillermo Apollinaire", en Grecia, núm. XX, I9ı9, págs. I y 2. "Un manifiesto", en España, núm. 292, dic. 1920, pág. II . "Más de Apollinaire", en España, núm. 294, 18 de dic. de 1920, págs. 10 y sigs. 
“Un poeta nuevo", en España, núm. 195, 2 de enero de 1919, pág. 12.

"El recuerdo de Apollinaire", en España, núm. 292, y dic. 1920, pág. ro.

"Reseña de Reflector", en España, núm. 294, año VI, 1920, página II.

Domenchina, J. J. "Poetas españoles del 13 al 31", en El Sol, 12 y 19 marzo 1933.

DoToR, ÁNGEL. "Del momento literario", en La Tribuna, Ciudad Real, 23 diciembre 1920.

"El movimiento ultraísta", en Vida Nueva, Puertollano (Cigarral), 20 diciembre 1921.

"La nueva literatura", en La Tribuna, Ciudad Real, 7 setiembre 1920.

"La nueva literatura. Contestando a don Guillermo de Torre", en La Tribuna, Ciudad Real, 25 set. I920.

"El ultraísmo", en El Telégrafo Español, 30 dic. 1920 (Reproducido en El Pueblo Manchego, Ciudad Real, 17 julio 1921).

Escosura, JoAQuín DE la. "Guillermo de Torre", en Cervantes, oct. 1920, págs. 85 a 96.

Espina García, ANTONIo. "Arte Nuevo", en España, núm. 285, 16 oct. de 1920, págs. 12 y 13.

EsCH, Ni:: "Magnificencia y belleza de la vida moderna", en Cosinópolis, núm. 39, setiembre 1921, págs: 119 a 129.

Fernández Almagro, Melchor. "La generación unipersonal de Gómez de la Serna", en España, núm. 362, 26 de marzo de 1923, pág. 10.

"Libros (Guillermo de Torre Hélices-Poemas 1923)", en España, núm. 357. 17 de febrero de 1923, pág. 12.

"Palabras hacia Gẹrardo Diego", en Alfar, núm. 48, marzo 1925, págs. 8 a 10.

FERnández Moreno, CÉsar. "Los escritores argentinos: Jorge Luis Borges. Esquema de Borges", en Ciudad, núms. 2-3, Buenos Aires, 2..$^{\circ} 30^{\circ}$ trimestre de 1955 , págs. 11 a 31 .

FUSTER, JoAN. "El tercer Diego (incompleto)", en Verbo, núms. 1920, octubre-diciembre 1950, págs. 44 y sigs. 
Gálvez, Pedro Luis. "De la fiesta del Ultra", en Grecia, núm. XVI, 1919, págs. 2, 3 y 4 .

Garfias, Pedro. "Anales literarios: el ULTRA", en Cervantes, marzo I9r9, págs. 66 a 69.

"La fiesta del Ultra", en Grecia, núm. XXX, I919, págs. 9 y Io, $y$ en Cervantes, mayo igr9, págs. 76 y sigs.

Gómez Carrillo, E. "París. El cubismo y su estética", en El Liberal, 30 de junio de I920, págs. I-2.

Gómez de la MATA, Germán. "Lo nuevo y lo bueno", en La Jornada, Madrid, 9 marzo I9I9́.

Gómez dE la SERna, Ramón. "El escandaloso libro de Guillén", en La Tribuna, Madrid, 21 julio I92I.

"Jorge Luis Borges. El Fervor de Buenos Aires", en Revista de Occidente, IV, núm. X, Madrid, 1924, pág. I 23.

"Mis siete palabras (Pastoral)", en Prometeo, año III, I9ro, número 13.

Gómez Santos, Marino. "Pequeña historia de grandes personajes: Eugenio Montes cuenta su vida", en El Pueblo, Madrid, 3 feb. 1960.

González, Melitón (Pablo Parellada). "Copio, copias, copiare", en $A B C$, Madrid, 20 abril I 920.

"Copio, copias, copiare", en ABC, Madrid, I. noviembre 1920.

GonZÁlez-Olmedilla, JuAN. "La epopeya del Ultra", en Grecia, número XLII, I920, págs. I 5 y 16.

"Mosaico leído por - en la fiesta del Ultra", en Grecia, número XVIII, año II, I9I9, págs. I a 3.

Gullón, Ricardo. "Gerardo de verdad", en Verbo, núms. I9-20, octubre-diciembre 1950, pág. I9.

HÉCTOR. "Reseña de Grecia", en Cervantes, mayo I9I9, págs. 157. 158.

"Reseña de Perseo", en Cervantes, mayo 1919, pág. I59.

"Homenaje a Gerardo Diego", en Verbo, Cuadernos literarios, Director José Albi con la colaboración de Joan Fuster, núms. 19-20, octubre-diciembre 1950.

Huidobro, Vicente. "Al fin se descubre mi maestro", en Alfar, núm. 39, abrh 1924, págs. 21 a 25. 
"Al fin se descubre mi maestro". Suplemento castellano de la revista Création, París, enero 1924.

JARNÉs, BENjAmín. "Antena y semáforo", en Alfar, núm. 54, noviembre 1925, págs. 19 a 21 .

"Pentagrama: Ramón", en Alfar, junio-julio 1924, núm. 41, páginas 6 a 8.

LASSO DE LA VEGA, RAFAEL. "Vertical. Manifiesto ultraista", en Cos. mópolis, XI, 1920.

LóPEZ-PARRA, ERNESTO. "Poetas viejos y poetas nuevos", en La Tribuna, Madrid, 20 junio 1921.

"El ultraísmo", en La Libertad, Madrid, 5 febrero 1921.

LOTHAIRE, JACQUES. "La jeune poésie espagnole", en Ça-lra, Amberes, mayo 1922.

Lucio, Nodier y Revello, Lydia. "Contribución a la bibliografía de. Jorge Luis Borges", en Bibliografia argentina de Artes y Letras, Buenos Aires, núms. IO-1I, págs. 43-111.

Machado, Antonio. "Reflexiones sobre la lírica", en Revista de Oc. cidente, Madrid, junio r925, pág. 364.

MaChado, Manuel. "Intenciones. Los jóvenes del Ultra", en El Liberal, Madrid, 30 junio 1919.

"Ultraísmo y citraísmo", en La Libertad, Madrid, ...

MaLesPine, Emile. "Lettre Lyonnaise. On discute du futurisme et du dada", en Les Tablettes, Lyon, enero 1922.

"Le poète Guillermo de Torre", en Manomètre, Lyon, marzo 1923.

Marichalar, Antonio. "Sintomas", en Revista de Occidente, setiembre 1924, tomo XV, págs. 394 a 398.

MarinetTI, F. T. "Fundación y manifiesto del Futurismo", en Prometeo, núm. 6, 1909.

MAYRAL, JOSÉ. "Los ultraistas. Un regocijante espectáculo en el Ateneo", en La Voz, Madrid, 2 mayo I921.

MoNTES, Eugenio. "En el centenario de Walt Whitman-El Atlante", en Cervantes, mayo 1919, págs. 70 a 76.

Noel, Eugenio. "El Ultraísmo", en Nuevo Mundo. 21 de enero 1921 .

"El ultraísmo en la lidia de reses bravas", en Nuevo Mundo, Ma. drid, 25 mayo 1923. 
"El ultraísmo, la magia del equilibrio en la expresión", en Nuevo Mundo, Madrid, 28 enero 1921.

OLMET, LuIS ANTÓN DE. "Ultra", en Heraldo de Madrid, Madrid, 12 febrero 1921 .

ORS, Eugeño D'. "Ultra tiene razón", en La Libertad, Madrid, I4 mayo 1921. (Artículo rećogido en el tomo V del Nuevo glosario. Poussin y el Greco.)

Pansaers, Clément. "La pintura expresionista alemana", en Cos, mópolis, XI, núm. 4I, año IV, mayo 1920, págs. 16I y sigs.

PASZKIEWICZ, Marjan. "El-estilo en la pintura moderna", en Alfar,

La Coruña, agosto-setiembre 1926, núm. 60, págs. 9 a 12.

PrIeto, ADOlFo. "El Martinfierrismo", en Revista de Literatura Ar. gentina, núm. 1, año I, Mendoza, dic. 1959, págs. 9 a 31 .

Requien, Marcel. "Ultra", en Promenoir, Lyon, octubre 1921.

Revello, Lydia. (Ver Lucio, Nodier.)

Rivas Panedas, JOSÉ. "El color de nuestros nombres", en Cervantes, mayo 1920, págs. 99 y sigs.

"Nosotros los de Ultra", en Grecia, núm. XXV, Sevilla, 20 agosto 1919. págs. 14 y 15, en Cervantes, julio 1919, págs. I 39 a 144. "Protesto en nombre de Ultra", en Cervantes, setiembre 19rg. 'págs. 142 a 147 .

ROYĖRE, JEAN, "Novísima literatura francesa" (s/Guillermo Apollinaire), en Cervantes, marzo 1919, págs. 70 a 76.

Segovia, Alberto DE. "Haciéndonos justicia. El Ultraísmo" (Transcrito de La Acción de Madrid), en Grecia, núm. XXXIII, 20 de nov. 1919, págs. 4 y 5 .

SiLva, GoY DE. "La apostasía de los ruiseñores o El triunfo de los loros y las ranas", en La Correspondencia de España, Madrid, 16 octubre 1922.

"Los ultra-terrenos y los ultra-marinos", en La Correspondencia de España, Madrid, 24 octubre 1922.

Soto, LuIs Emilio. "Los sesenta años de Cansinos-Asséns", en Co. mentario, Buenos Aires, enero-febrero-marzo 1955, págs. 5 a 12.

TAPIA, LUIS DE. "Coplas del día. jUltra!", en La Libertad, Madrid, 2 febrero 1921.

TORRE, GUILlERMO DE. "El arte decorativo de Sonia Delaunay-Terk". en Alfar, núm. 35. dic. 1923, págs. 18-19. 
"Bengalas", en Alfar, agosto 1924, núm. 42, pág. 14.

"Bibliografía de la novísima lírica francesa", en Cervantes, agosto 1920, págs. II 8 a 126.

"El cinema y la novisima literatura: Sus conexiones", en Cosmó. polis, núm. 33, setiembre 1921, págs. 96 a 107.

"Contemporary Spanish Poetry", en The Texas Quarterly, IV, núm. I, The University of Texas, Austin, Spring, 1961, págs. 60 y siguientes.

"Los espejos curvos de un humorismo forzado", en Cosmópolis, XI, 1922, págs. 329 a 333 y en Nosotros, núm. 161, octubre 1922. "Estética del yoísmo ultraista" (Leído en Parisiana el 28-1-21), en Cosmópolis, núm. 29, mayo 1921, págs. 51 a 61.

"Gerardo Diego", en Martín Fierro, núm. 43, julio 15, agosto 15. 1927.

"La imagen y la metáfora en la novisima lírica", en Alfar, diciembre 1924, núm. 45, págs. 20 a 26.

"Interpretaciones críticas de nueva estética", en Cosmópolis, set. 1920, núm. 21, págs. 89 a 96.

"El movimiento ultraista español", en Cosmópolis, nov. 1920, nímero 23, págs. 473-495.

"Las novisimas directrices literarias. Carta abierta a Don Angel Dotor", en La Tribuna, Ciudad Real, 14, 16 y 17 setiembre 1920. "Paralelismo entre Picasso y Ramón", en Síntesis, Buenos Aires, 1928.

"El pim-pam-pum de Aristarco. Crítica de críticos", en Proa, números 4 y 5, Buenos Aires, noviembre y diciembre 1924 .

"Un poema discutido de Apollinaire", en Ultra, núm. 19, diciembre 1921.

"La poesía creacionista y la pugna entre sus progenitores", en Cosmópolis, agosto 1920, núm. 20, págs. 589 a 605 .

"La Poesia de hoy, por el teorizante Epstein", en Nosotros, XXXIX, núm. 151, diciembre 1921, págs. 545 a 556.

"Los poetas cubistas franceses", en Cosmópolis, núm. 36, diciem. bre 1921, pág. 603 .

"Problemas teóricos y estética experimental del nuevo lirismo", en Cosmópolis, núm. 32, agosto 1921, págs. 585 y sigs. 
"Rasgos polémicos" (Réplica a Vicente Huidobro), en Alfar, abril 1924, núm. 39, págs. 26-30.

"El renacimiento xilográfico. Tres grabadores ultraístas (Wladyslaw Jahl, Norah Borges, Rafael Barradas)", en Cosmópolis, XI, núm. 4I, 1922, págs. 333 y sigs. y en Nosotros, núm. 161, oct. 1922.

"Réplica a Vicente Huidobrio", en Alfar, núm. 39, Madrid, abril I924.

"Teoremas críticos de nueva estética", en Cosmópolis, octubre 1920, núm. 22, págs. 284-296.

"Ultraísmo contra sencillismo" (Réplica a Vicente Medina), en Proa, núm. 2, Buenos Aires, diciembre 1922.

"Valoración estética de los elementos modernos", en Cosmópolis, $\mathrm{X}$, núm. 37, 1922, págs. 52 y sigs.

"Veinte años de literatura española", en Nosotros, LVII, 1927. págs. 315-322.

"Los verdaderos antecedentes líricos del creacionismo en Vicente Huidobro. Un genial e incógnito precursor uruguayo: Julio $\mathrm{He}$ rrera Reissig", en Alfar, setiembre 1923, núm. 32, págs. I4-1 7.

TRISTÁn (RAmón Gómez de la SERNA). "Proclama futurista a los españoles", en Prometeo, II, núm. 20, año III, I9ro.

Tzara, Tristan. Boletín Dadá, núm. 6, París.

VALLE, AdRIANo DEL. "Algunas palabras sobre la rileda de color, de Rogelio Buendia", en Alfar, junio-julio 1924, núm. 41, págs. 24-25. "Nuestras Normas", en Grecia, núm. I, año I, 1918, págs. I y 2. "La Nueva Lírica y la revista Cervantes", en Grecia, núm. XII, 1919, págs. 12 a 14.

"Ramón Gómez de la Serna o el sentido de la universalidad", en Alfar, núm. 50, año $\mathrm{V}, 1925$, págs. 6-7.

VANDO-VILlAR, ISAAC DEL. "La plenitud del Ultraismo, Grecia ha cumplido su segundo aniversario", en Grecia, núm. L, año III, 1920, pág. 5 .

"La transmigración de Grecia", en Grecia, núm. XLII, año II, 1920, pág. 9.

Vighi, Francisco. "Tertulia" (poesia), en Grecia, Madrid, $10^{\circ}$ setiembre 1920. 


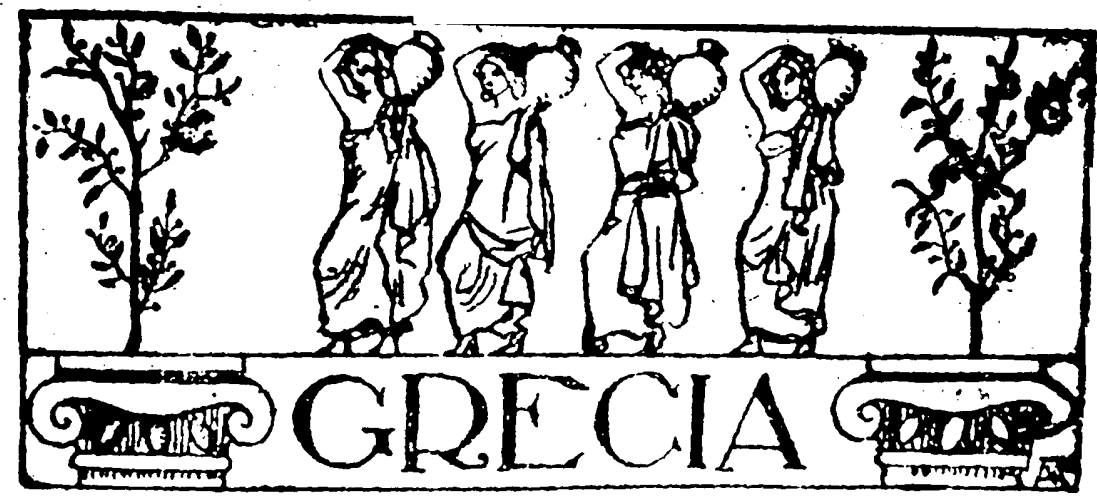

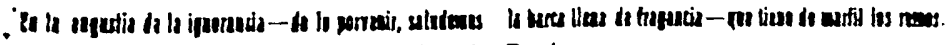
Ruetin Oanio

\begin{tabular}{|c|c|c|}
\hline ANNO II & $\begin{array}{l}\text { HEVITA IIETENAL DE LITERATUHA } \\
\text { SEVILLA } \\
\text { Redacción: Amparo, } 20 \\
\text { 30 DE JUNIO DE 1999 }\end{array}$ & NUM. XX \\
\hline
\end{tabular}




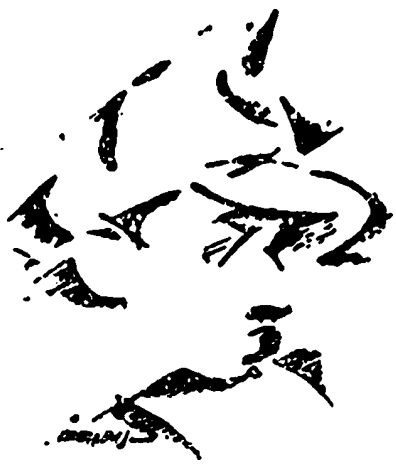

$R$

T<smiles>[TlH]</smiles>

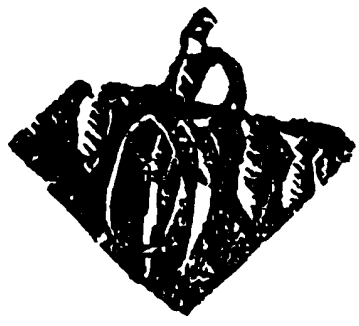

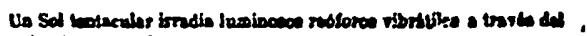
multidrion od aloo.

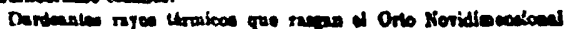

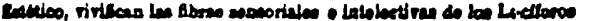
Untentates.

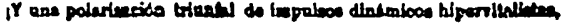

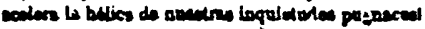

\section{MDICE DE SENSACIO. \\ NES, VISIONES Y CE PBRRACIONES :: : :}

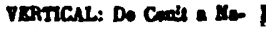

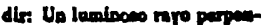

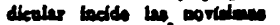

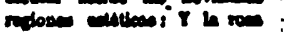

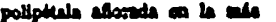

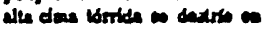

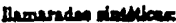

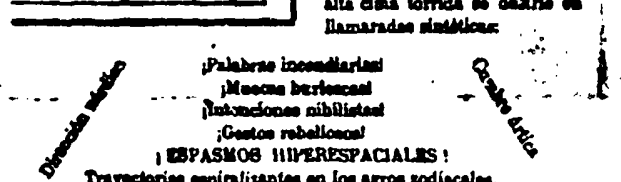

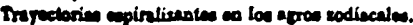

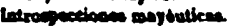

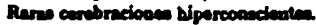

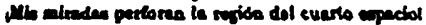

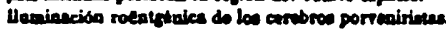

Sinden mporatricen.

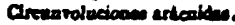

Acrobscie Itrien

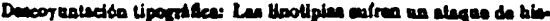

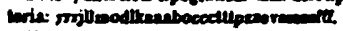

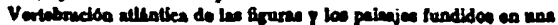

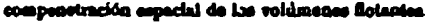

Aitrizscionse grometrice.

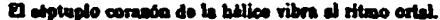

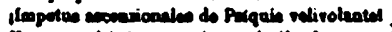

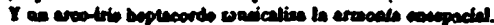

Lo the enoms fero.

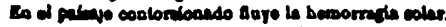

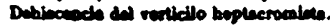

ratilio olmiteoles.

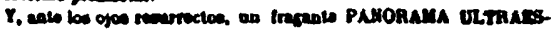
proint.

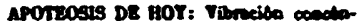

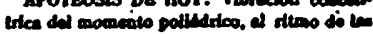
hallow comedialan.

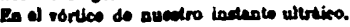

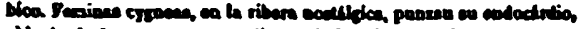

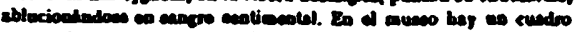

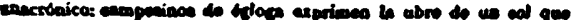

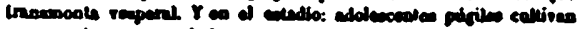

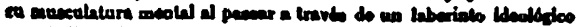
7 Tertaliene ab-trectemente.

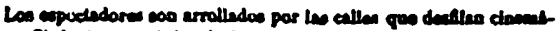

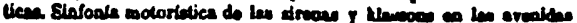

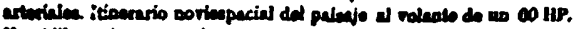

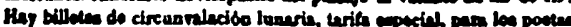

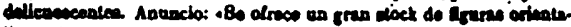

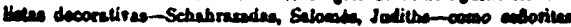

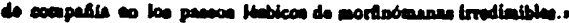

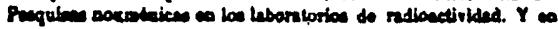

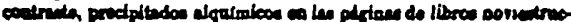

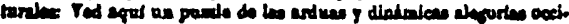

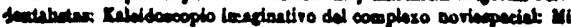

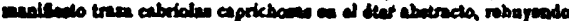

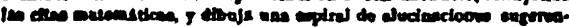

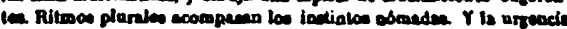
insoredon juntilec is ensccion rertieal.

$\frac{\because: \text { ACTITUD }}{\text { VERTICALISTA }}$

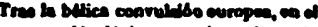

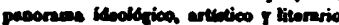

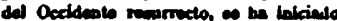

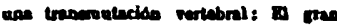
erros, teadido cono ane socke epen-

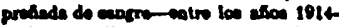

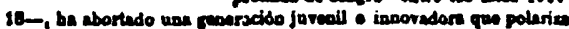

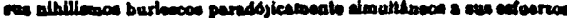

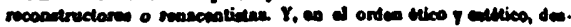

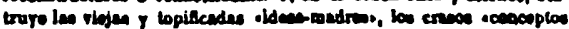

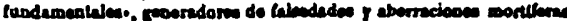

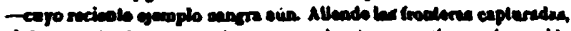

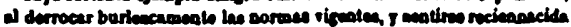

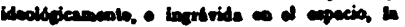

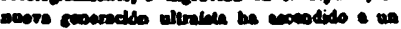

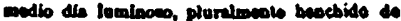

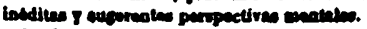

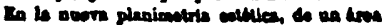

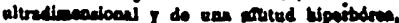

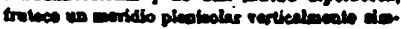

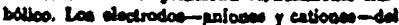

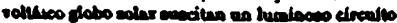

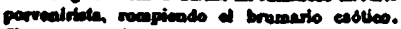

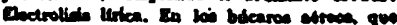

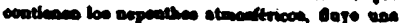

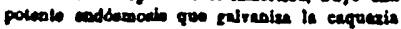

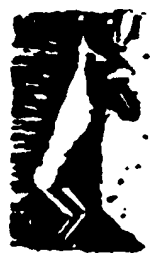

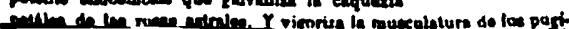




: : RNOVACIONES

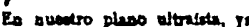

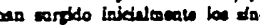

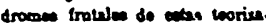

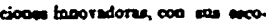

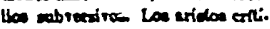

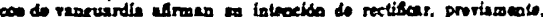

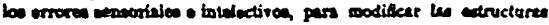

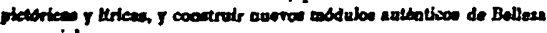
$\rightarrow$ iacial.

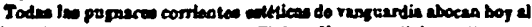

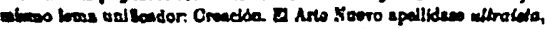

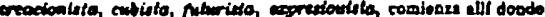

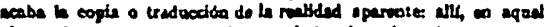

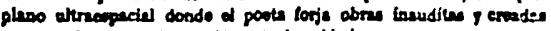

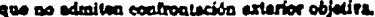

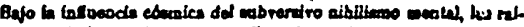

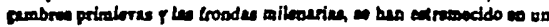

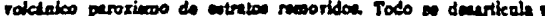

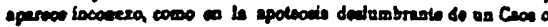

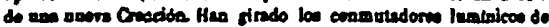

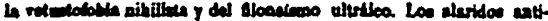

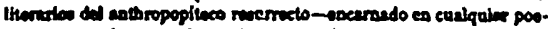

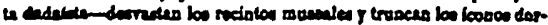

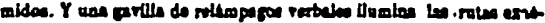

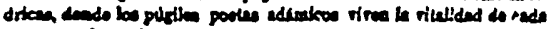

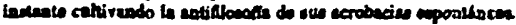

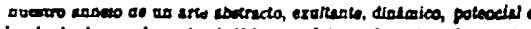

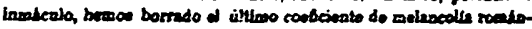

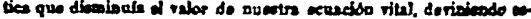

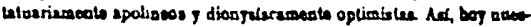

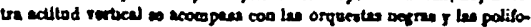
ofse motoristlene.

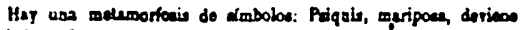

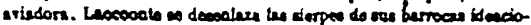

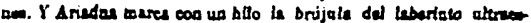
pecial.

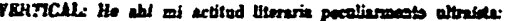

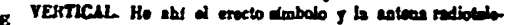

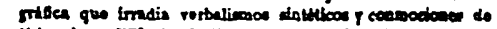

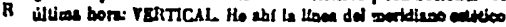

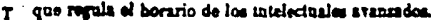

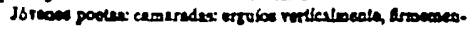

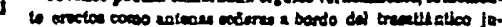

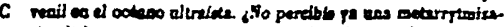

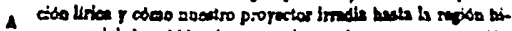

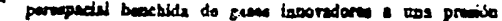

L. tideran

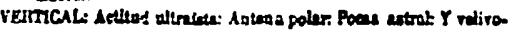

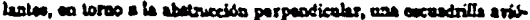

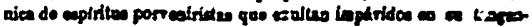
cialided cols.

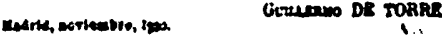

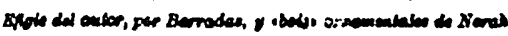
Barga.

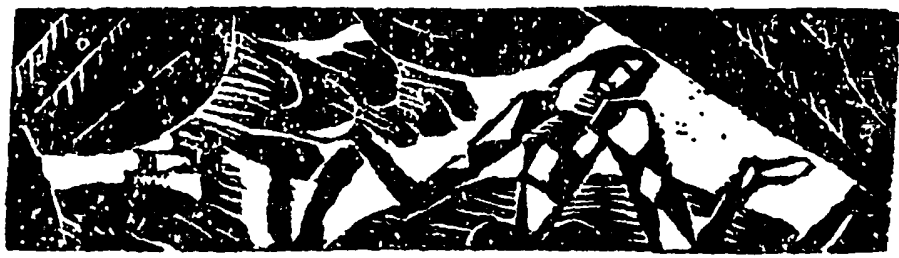

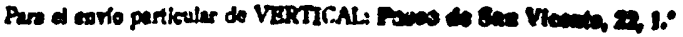

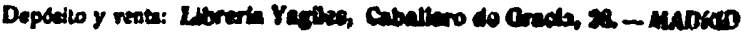

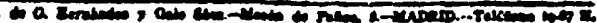


OBKVANTBE

87

ESTAYQUE
EZTHOONE

Dos alas negras sobre los polluelos

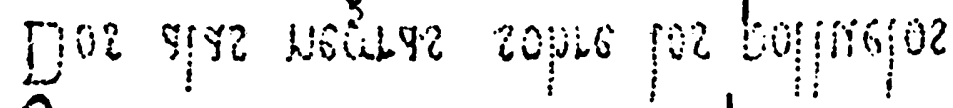
Que rompen a picotazos los cascarones

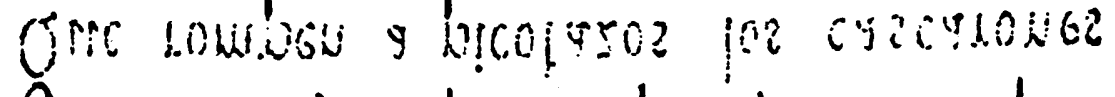
Qué pescador lanzó los dos anzuelos

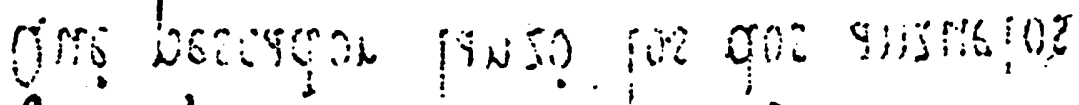
Entre los pececillos de oro?

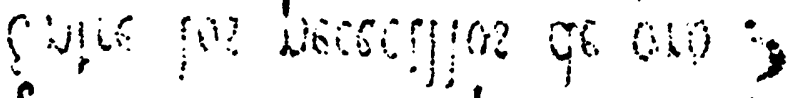
Enouna rama de fos surtidores Sézescama un pez polador

Todos los disparos

Centran los blancos concentricos En la retind del tambor 


\section{POEMA ULTRAİSTA}

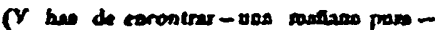
anaride to barea a cere ribere)

A. 4 .

Solo, hidrópico, solo

estabs porgue lodos-los unos y los otros-

huyeroa. Coso a perto earasso,

huyeron.

Me dejaron una ventana abietra.

Era la noche:

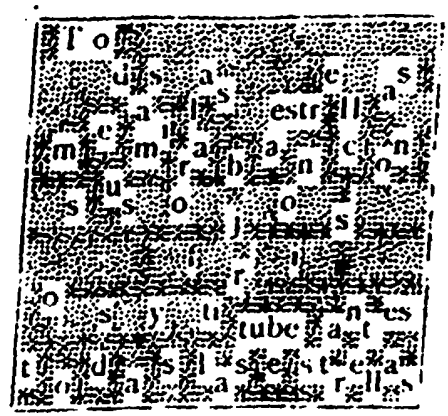

Se habian condensado en mi ventana.

I. Ia luna, paes un mourente

imonóculo impertineote!

$$
\text { Ya }
$$

fuc.

Yo eatabe wolo y grasiedto de la última pomads inútil.

Les tres hermanas viaieros

La mayor me trojo el olto.

en ailencio.

I. mediana ol sudario.

La mle pequesa me bees en la boca.

Las estrellar se fuema, ovejas, 2 pastar porque

las llasió In sirena del pastor de la tabrica.

$Y$ me las encontré ea el otro valle.

ANGFL CA.VDIZ. 
RETRATO DE CANSINOS ASSENS POR BARRADAS

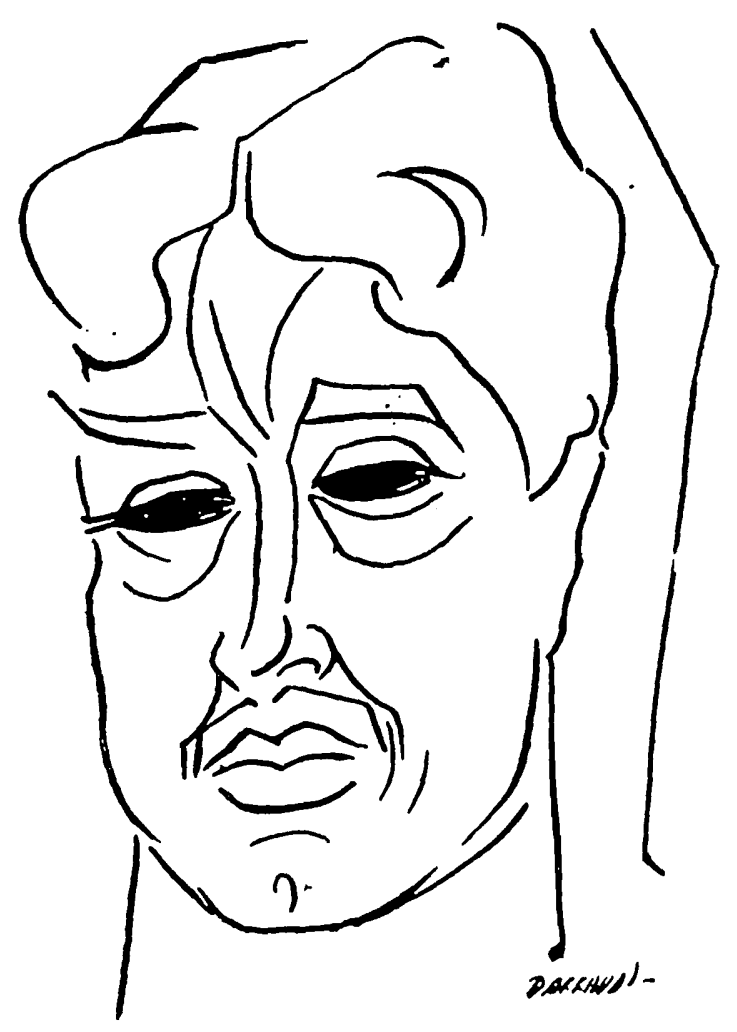



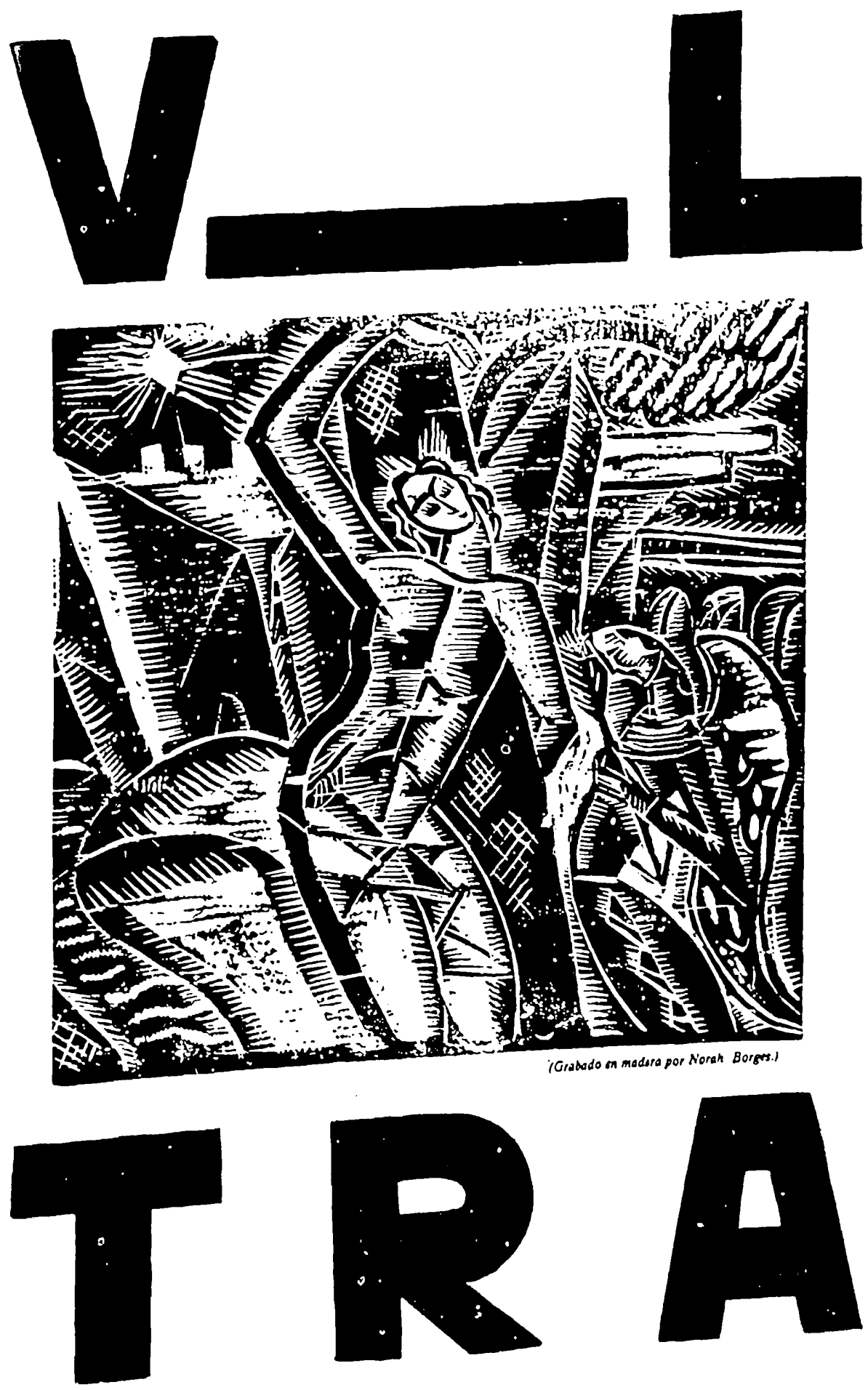


\section{$P A|S A| E$ P L A S T I C O}

Aeoioda igniscente en el vórtice de la camplina estival

Dardeantes cohetes solares hienden $p$ El Sol maduro

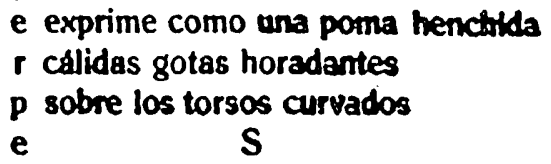

El paisaje se magnifica

en el meridio plenisolar

e

n

(Se adivina a Dios que en su cabina 0

ante su térmico cuadfo distribuidor

acumula trillones de calorias)
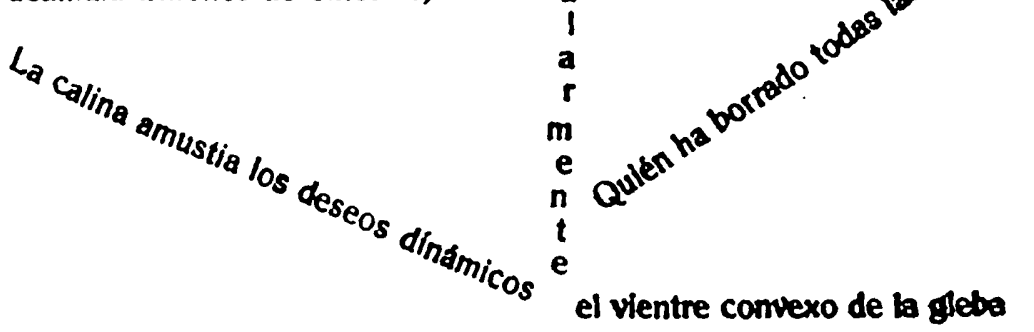

Los cuerpos enervados

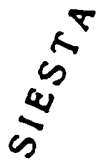

tendidos sobre el agro

crepitan en un orgasmo de ardentlas

En la atmósfera embriagada gravita el solsticio

A

Olas de cierzo azul siegan los blondos trigales $Z$

Las espigas gigantes estrlan

el zatiro dérmico del horizonte

Interroglantes hoces aplacan la

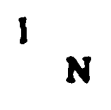

I

avidez de los tallos erectos

A

Los olvos contorsionan sus troncos hendidos por el dall febeo 
Vignale P. J. y Tiempo, CÉsar. "Algunas páginas de la Exposición de la actual poesía argentina, por P. J. Vignale y César Tiempo", en Martín Fierro, núm. 39, 1927.

ZOZAYA, ANTONIO "Las musas inquietas", en La Libertad, Madrid, 10 febrero I92I.

\section{PERIÓDICOS Y REVISTAS CITADOS}

$A B C$. Madrid. Diario.

Alfar. (Ver Revista de Casa América.)

Atenea. Santiago de Chile. Revista.

Caballo de Fuego. Buenos Aires.

Ça-Ira. Amberes.

Cervantes. Revista mensual iberoamericana. Madrid.

Ciudad. Buenos Aires.

Comentario. Revista trimestral. Buenos Aires.

Cosmópolis. Revista mensual ilustrada. Madrid.

La correspondencia de España. Diario universal de noticias. Madrid.

Création. Directeur: Vicente Huidobro. París. Revista.

Cruz y Raya. Revista de afirmación y negación. Madrid.

El Diario Español. Buenos Aires.

La Esfera. Ilustración mundial. Madrid. Semanal.

España. Semanario de la vida nacional. Madrid.

España Nueva. Diario de la noche. Madrid.

El Figaro. Diario liberal, científico, literario. Madrid.

Grecia. Revista quincenal de literatura. Sevilla-Madrid.

Heraldo de Madrid. Diario independiente. Madrid.

Horizonte. Revista de arte. Madrid. Quincenal.

Los lunes del "Imparcial". Madrid.

Indice. Madrid, 1921-1922. Revista.

Inicial. Revista bimensual. Buenos Aires.

Insula. Revista bibliográfica de ciencias y letras. Madrid. Mensual.

La Jornada. Madrid. Diario.

La Libertad. Madrid. Diario.

El Liberal. Madrid. Diario.

Manomètre. Lyon. 
Martín Fierro. Periódico quincenal de arte y crítica libre. Buenos Aires. Mediodía. Revista de Sevilla.

Mercurio de Francia. París.

Meseta. Pápel de literatura. Valladolid.

La Nación. Buenos Aires. Diario.

Noreste. Zaragoza. Revista.

Nordeste. Buenos Aires.

Nosotros. Buenos Aires. Revista.

Nuevo Mundo. Madríd.

Papel de Aleluyas. Hojillas del calendario de la nueva estética. Huelva.

Parábola. Cuadernos mensuales de valoración castellana. Burgos.

El Parlamentario. Madrid. Diario.

Perseo. Revista iberoamericana. Madrid.

Plural. Revista mensual de literatura. Madrid.

Poesía Española. Segunda época. Madrid.

Prisma. Revista-mural. Buenos Aires.

Proa. Revista de literatura. Buenos Aires.

Promenoir. Lyon.

Prometeo. Revista social y literaria. Madrid. Mensual.

El Pueblo. Madrid. Diario.

El pueblo manchego. Ciudad Real.

Los Quijotes. Madrid. Revista.

Reflector. Madrid. Revista.

Revista de Casa América. La Coruña.

Revista de Occidente. Madrid. Trimestral.

Ronsel. Revista de la nueva generación gallega. Galicia.

Sintesis. Artes, ciencias y letras. Buenos Aires. Mensual.

El Sol. Diario independiente. Madrid.

Tableros. Revista internacional de arte, literatura y crítica. Refundición de Grecia. Quincenal. Madrid.

The Texas Quarterly. University of Texas. Austin.

El Tiempo. Madrid.

Tobogån. Madrid. Revista.

La Tribuna. Ciudad Real.

La Tribuna. Madrid. 
Ultra. Poesía. Crítica. Arte. Madrid.

Ultra de Oviedo. Hoja quincenal de literatura.

Valoraciones. La Plata, Argentina. Revista.

Verbo. Cuadernos literarios. Alicante.

La Verdad. Suplemento literario. Murcia.

Verso y Prosa. Boletín de la joven literatura. Murcia.

La vie des lettres. París.

Vértices. Madrid.

Vida nueva. Puertollano.

La Voz. Diario independiente de la noche. Madrid. 
Í N D I C E S 


\section{INDICE DE NOMBRES PROPIOS}

Abril, Manuel, 223, 228.

Alberti, Rafael, 50, 59, 168, 169.

Albi, José, 133, 217.

Aldama, J. M., 58.

Aleixandre, Vicente, 50, 121, 169, 218.

Alonso, Amado, 217.

Alonso, Dámaso, 10, $11,59,91,111$,

$114,132,126,166,168,217$.

Altolaguirre, Manuel, 50.

Alvar, Gonzalo de, 56.

Allard, Roger, 40, 180, 186.

Allendy, 207.

Anderson-Imbert, E., 144, 217.

Anguita, Eduardo, 102, $217,220$.

Apollinaire, Guillaume, 38, 40, 43, 72,

92, 96-98, 102, III, I15, 140, 151, $180,183,186,192,195,197,217$,

$222,224,225-227,230,231$.

Aragon, L., 225.

Aretino, 180.

Aroca, J. de, 33, 34 .

Arrieta, Rafael Alberto, 219.

Arroyo, César E., 52, 87, 224.

Astrana Marín, Luis, 217.

Azorín, 166.

Bacarisse, Mauricio, 40, 78, 8x-83, I18, 164, 186, 197, 224 .

Bajarlía, Juan Jacobo, 218, 224.

Ballesteros de Martos, 52.

Baroja, Pío, 52, 196.

Barradas, 55, 57, 58, 60, 85, $115,232$.
Baudelaire, 14, 92, 195, 219.

Bcauduin, Nicolás, 112, 224.

Bécquer, Gustavo Adolfo, 155, 185, 195.

Becher, Johannes, 99.

Bedoya, Manuel A., 82, 196, 197, 224.

Bello, A., 58.

Benlliure y Tuero, Mariano, 224.

Bergamín, José, 50.

Bernárdez, Francisco Luis, 10. -

Bores, Francisco, 60, 115.

Borges, Jorge Luis, $7,13,38,56-58$, $67,68,83,89,96,98,99,107,110$, 143-147, 166, 201, 204, 219, 222, 224, 225, $227-229$.

Borges, Norah, 55, 60, I15, 220, 232.

Bousoño, Carlos, 15, $110,218$.

Bouvier, Emile, 218.

Bóveda, Xavier, 29-35, 40, 53, 58, 63 , $82,159,160,181,225$.

Braque, II5.

Breton, 115.

Brezo, Juan del, 78.

Buendía, Rogelio, 40, 41, 53, 57, 59, $60,162,181,187,232$.

Campoamor, 196.

Campos, Jorge, ro.

Cándiz, Ángel, I14.

Cangiullo, Francesco, III.

Cansinos_Asséns, Rafael, 10, 15-17, 22 , $25-38,40-43,47,48,52,53,56,58$, $59,62-64,66,71-73,79,87,89,92$, 
110, 123, 126, 143, 144, 151, 159, Diez Echarri, 20, 219.

I60, 161, 162, 175, 178-182, 187, Domenchina, J. J., 227.

I88, I92, $218,225,230$.

Dotor, Angel, 227, 231 .

Cantó, 32.

Durán, Manuel Maria, 56.

Carilla, Emilio, 225.

Carrera Andrade, Jorge, 222.

Carrere, Emilio, 52.

Casal, Julio J., 60.

Cassou, Jean, 225.

Cavestany, 32.

Cebreiro, Alvaro, 6r.

Cejador, Julio, 32.

Cendrars, Blas, 44, I I5, 180, 186, 195.

Cernuda, Luis, 23, 50, 169, 218.

Cervantes, Miguel de, 178 .

Cetina, Gutierre de, 185 .

Echegaray, 62.

Edwards, Joaquín, 163.

Elías, Luis, 57, 58.

Eluard, Paul, 21 .

Emerson, 185, 206.

Epstcin, Jean, 93, $219,231$.

Esch, M., 227.

Escosura, Joaquín de la, 46, 56, 140, $162,181,227$.

Espina, Antonio, 50, 53, 57, 163, 196, 227.

Ciria y Escalante, José de, 58, 81, 83, Esquerra, Ramón, 219.

$85,160,226$.

Cirlot, Juan Eduardo, 218 .

Cocteau, 44.

Comet, César A., 34, 40, 53, 62, 80, $81,83,85,160,181,224,225$.

Conde, Carmen, 50.

Cordoza y Aragón, Luis, 19.

Correa Calderón, Evaristo, 37, 40, 6r, I64, 18r, 226.

Cossío, José María, 50, 60, 218.

Cruzado, Clemente, 226.

Cubero, Antonio M., 21, 28, 56, 84. I63, 226.

Chabás y Martín, Juan, 22, 53, 161, I66, $218,226$.

Chadourne, Luis, I80.

Chazal, Thomas, 103, 213.

Delaunay, 27, 60, 78, 103, $115,230$.

Dermée, Paul, 44.

Diaz Plaja, Guillermo, I66, 218.

Dicenta, Joaquín, $52,82,83$.

Diego, Gerardo, 10, 12, 39, 46, 50, 53 , $57-60,80,83,102,108,113,125^{\circ}$ $132,151,160,195,211,218,220$, 226.228, 231.

Díez-Canedo, Enrique, 58, 66, 97, I I I, 226.

Fernández Almagro, Melchor, I60, 227.

Fernández Moreno, César, 219, 227.

Fichte, 99.

Forcada-Cabanellas, 219.

Fort, Paul, 17, 186.

Frick, I8o, I86.

Fricdrich, Hugo, 14, 93, 219.

Fuster, Joan, 133, 217, 227, 228.

Galindo, Rafael, 78 .

Gálvez, Pedro Luis de, 72, 74, 9I, I64, I83, 228.

García I ..., Federico, 11, 50, 59, $121,157,158,168,169$.

Garfias, Pedro, 20, 34, 37, 40, 44, 53, $59,72,73-76,78,83,147-149,175$, 177, $178,181,2.28$.

Ghiano, Juan Carlos, 219.

Gide, André, 34.

Gómez Carrillo, Enrique, 56, 86, 228.

Gómez de la Mata, Germán, 86, 228.

Gómez Santos, Marino, 38, 228.

Gómez de la Serna, Javier, 16.

Gómez de la Serna, Ramón, 15-22, 27. $39,46,55,57,58,62,95,160,174$, 187, 219, 223, 225, 227-229, 231, 232. 
Góngora, I1, 80, 168, 185, 191, 199. González, Melitón (seudónimo). V. Parellada.

González Blanco, Andrés, 85, 178.

González Lanuza, Eduardo, 68, 201.

González Olmedilla, Juan, 40, 72-74, $76,87,163,176,178,183,188$, 228.

González-Ruano, César, Io, 28, 55, $57,160,162-163,220$.

González del Valle, Julio, 60.

Gourmont, Remy de, 17.

Greco, El, 55, 221, 230.

Gris, Juan, 60, 115, 220.

'Guallart, Augusto, 55.

Guerrero, Viuda de, 10.

Guillén, Jorge, II, 50, 59, 60.

Gullón, Ricardo, 221, 228.

Gutiérrez Gili, Juan, 57, 162, 220.

Hahn, W., 99.

Hatzfeld, Helmut, 220.

Héctor, 228.

Hegel, 99.

Henríquez Ureña, Pedro, 220.

Hernández Luquero, 86.

Herrera y Reissig, Julio, 80, 82, I96, 222, $224,232$.

Heynicke, Kurt, 99.

Homero, 190.

Huidobro, Vicente, 7, 25.7.25-27, 29 , $34,38,40,43,47,53,59,62,92$, 101-106, I10, 114, 115, 118-125, 127, 134, 143, 160, 180, 186, 191, 196, $205,215,217,220,221,223,225$, 228, 232.

Ibarra, Jaime, 40, 57, 160.

Iglesias Caballero, Pedro, 33, 34, 181. Iglesias, Fernando, 33, 34 .

llusión, Jacinto, 187.

Ingenieros, José, 52, 207.

Jacob, Max, 43, 96, I15, 180, 183-186, $221,222,225$.

EL ULTRAISMO. - I6
Jahl, Wladyslaw, 27, 55, 57, 59, 78, 84, I15, I16, 232.

Jarnés, Benjamín, 229.

Jiménez, Juan Ramón, 13, 15, 22-24, $58,6 \mathrm{r}, 112,162,180,186,221$.

Joyce, 218.

Juan, Guillermo, 68, 20r, 225.

Kayser, Wolfgang, 22r.

Keats, 195.

Keller, J. T., 100.

Klemm, Wilhelm, 99, 100, 144.

Klingsor, 17, 180, 186.

Konrad, Hedwig, 221.

Lapi, Fernando de, 164, 221.

Larrea, Juan, 46, 53, 114, 132-139, 169, 211 .

Las, Juan (seudónimo). V. CansinosAsséns, Rafael.

Lasso de la Vega, Rafael, 40, 46, 53. $57,80,81,83,84,92,155-157,186$. 229.

Lebesgue, Phileas, 62.

Léger, 115.

Linera, Emilio, 39.

Lope de Vega, 168.

López-Parra, Ernesto, 53, 60, 80, 8I. $83,84,164,229$.

Lothaire, Jacques, 229.

Lucio, Nodier, 229.

Luis de León, fray, 190.

Luque, Tomás, $83,85,164$.

Llosent y Marañón, Eduardo, 50.

Llovet, Juan José, 82, 83197.

Machado, Antonio, 13, 59, 221, 229.

Machado, Manuel, 13, 86, 229.

Malespine, Emile, 229.

Mallarmé, I4, 53, 80, 92, III, 180 , 190, 191, 195. 197.

Mariani, Luis Claudio, 4I.

Marichalar, Antonio, 229.

Marịnetti, 17, 18, 43, 45, 72, 77, 92.

97, 98, III, 179, 221, 229.

Mayral, José, 229. 
Medina, Vicente, 221, 232.

Mir, M., 217.

Montes, Eugenio, 21, 29, 38, 53, 58,

$59,83,151-153,166,228,229$.

Montes, Hugo, 104, II4, 220, 221.

Montesquiou de Fezensac, 189.

Morand, Paul, 44.

Moreno Villa, José, 50, 59, 186.

Mosquera, Luis, $50,57,164,18 \mathrm{r}$.

Neruda, I24.

Nerval, Gerardo, 160.

Nervo, Amado, 52.

Newmark, Maxim, 22I.

Noé, Julio, 217.

Noel, Eugenio, 229.

Núñez de Arce, 196.

Olmedo Zurita, Pedro, 164.

Olmet, Luis Antón de, 230.

Onis, Federico de, II, 102, 106, 163, 221.

Ontañón, Eduardo, 61, 163.

Ors, Eugenio d', 55, 86, 187, 230.

Ortega y Gasset, José, 34, 93, 95, $22 \mathrm{I}$.

Pansaers, Clément, 99, 230.

Pardo Bazán, Emilia, 52.

Parellada, Pablo, 228.

Paszkiewicz, Marjan, 27, 55, 60, 78, 115, 116, 230.

Peña, Manuel de la, 59, 84, 163, 222.

Pérez de Ayala, Ramón, 18, 186.

Pérez Doménech, I. José, 84, 163.

Pernil, 81.

etit, Juan, 219.

icabia, Francis, 44, 209.

'icasso, I15, 180, 220, 231.

'icon, Gac̈tan, 222.

'into, Juan, 144, 222.

'lagge, H., 100.

'oussin, 55, 22x, 230.

?rieto, Adolfo, 230.

?rieto y Romero, 163.
Puche, Eliodoro, 40, 53, 85, 160, 18r.

Putnam, Samuel, 222.

Quiroga Pla, 181.

Rachilde, I7.

Raida, Pedro, 41, 44, 53, 72, 163.

Rello, Francisco, 53, 82, 83, 163 .

Rello, Guillermo, 53, 82, 83, 163.

Requien, Marcel, 230.

Revello, Lydia, 229, 230.

Reverdy, Pedro, 26, 40, 46, 92, ror, 115, 180, 186, 192, 195, 222, 225.

Ribémont, Dessaignes, Georgar 210.

Rimbaud, 14, 92, $195,197$.

Ríos Patrón, José Luis, 222.

Risco, S., 58.

Risco, Vicente, 153.

Rivas, Humberto, 21, 53, 54, 57, 79, $83-85,112,16 \mathrm{~J}$.

Rivas Panedas, J., 21, 34, 40, 53, $57-59,81,83,84,87,90,103$, II 2 , $113,146,153-155,16 \mathrm{I}, 181,230$.

Roca Franqueca, 20, 219, 222.

Rodríguez Alcalde, Leopoldo, 222.

Rodríguez Marin, 178.

Rolland, Romain, I44.

Romero, José M. ${ }^{2}, 72,73,18 \mathrm{r}, 187$.

Romero Martínez, Miguel, 4I, 44, 45. $63,72,74$.

Romero y Murube, 50.

Rouault, I15.

Royère, Jean, 98, 230.

Rubén Darío, 13, 14, 41, 42, 80, 96. 102, 155, 157, 185, 195.

Rubiner, Ludwig, 144.

Ruywerner, I80.

Saint-Pol Roux, 17, 186.

Sáinz de Robles, Federico Carlos, 222.

Salazar, Adolfo, 58.

Salinas, Pedro, II, 50, 60, 222.

Salmon, André, 44, 225.

San-Saor, Luciano de (seudónimo). V.

Sánchez Saornil, Lucía.

Sánchez, Juan Sebastián, 222. 
Sánchez Saornil, Lucía, 40, 53, 161. Vagts, A., 99.

Santos Torroella, Rafael, 10, 222.

Schreyer, L., 99.

Segovia, Alberto de, 86, 230.

Silva, Goy de, 58, 62, 181, 230.

Silva, José Asunción, 52.

Soto, Luis Emilio, 230.

Soupault, 44.

Souvirón, José María, II, 222.

Spencer, 202.

Stadler, E., 99.

Stecchetti, 45.

Stirner, 144.

Stramm, A., 99.

Stummit, $\mathrm{CH}, 99$.

Sureda, Jacobo, 163.

Swinburne, 195.

Tapia, Luis de, 230.

Tennyson, 195.

Tiempo, César, 143, 223, 233.

Torre, Guillermo de, 8-10, 12-16, 19, $22,24,26-28,32-34,38-40,46,49$, 50, 53-66, 68, 7x, 76-78, 80, 84, 85. 90.93, 96-99, 101, 102, I11, I13, II7, 134, 140-142, 144, 147, 150, 153, 157, 160, 162, 165, 166, 18r, $201,217,222,225,227,229,230$.

Torrente Ballester, Gonzalo, 18, 19, 222, 223.

Torres Villarroel, 14 .

Tristán (seudónimo). V. Gómez de la Serna, Ramón.

Tzara, Tristan, 44, 54, 192, 209, 225, 232.

Unamuno, Miguel de, 13, 52186.

Undurraga, Antonio de, 168, 220, 223. Urbina, Luis G., 52.

Valbuena Prat, Angel, 167, 223.

Valéry, 225.

Valverde, Salvador, $18 \mathrm{r}$.

Valle, Adriano del, 40, 4I, 53, 58, $60,71,72,74,76,150.151,175$, $178,181,223,226,232$.

Valle Inclán, Ramón del, $13,18$.

Vando Villar, Isaac del, $29,37,38$, $40,41,46,49,57,58,63,64,72$. $74,76,157-159,175,177,178,181$. $188,195,223,232$.

Vázquez Díaz, 60, 78, 11 .

Vera, Santiago, 57, $5^{8}$.

Verlaine, 42, 195.

Vighi, Franciseo, 58, 85, 155, 163, 232.

Vignale, Pedro Juan, 143, 223, 233.

Villaespesa, Francisco, 52.

Villalón, Fernando, 50, 6r, 218.

Virgilio, 191.

Vivanco, Luis Felipe, 223.

Warren, Austin, 223.

Wellek, René, 223.

Whitman, 53, 98, 99, 144, 179, 229.

Wilde, Oscar, 17, 185 .

Wyzewa, Teodoro de, rgo.

Xenius (seudónimo). V. Ors, Eugenio d'.

Zañartu, José, 220.

Zara, Jacobo, 180.

Zorrilla, José, 195.

Zozaya, Antonio, 233.

Zubillaga, Luis, 56 . 


\section{INDICE GENERAL}

Págs.

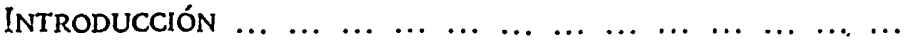

El tema, 7. - Las fuentes, 8. - Criterios seguidos, 8.

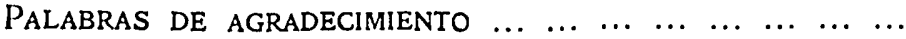

CAP. I : Relación del ultraísmo con el pasado literario español.

Panorama literario y relación con el modernismo, $\mathbf{r}$. Antecedentes del ultraísmo en España: Ramón Góo mez de la Serna, 15. - Juan Ramón Jiménez, 22.

ĆÁP. II : Desarrollo histórico del movimiento ... ... ... ...

Los comienzos, 25. - El ultraísmo a través de las re$25-88$ vistas : Los Quijotes, 39. - Grecia, 40. - Cervantes, 52. - Ultra, 54. - Ultra, de Oviedo, 55. - Cose mópolis, 56. - España, 56. - Tableros, 57. - Pero seo, 57. - Reflector, 58. - Horizonte, 59. - Vértices y Tobogán, 59. - Alfar, 59. - Otras revistas ultraístas, 6r. - Manifiestos, 62. - Repercusión periodística, 86.

CAP. III : Relación del ultraísmo con otras escuelas o movimientos de vanguardia $\ldots \ldots \ldots \ldots \ldots$

El ultraísmo español no es una escuela, sino un haz de direcciones renovadoras, 89. - Estructur común de la lírica de vanguardia, 92. - Relación d ! ultraísmo con el futurismo, el cubismo, el dadaísmo, 97. - Ul, tra y el expresionismo, 99. - El ultraísmo y el creacionismo, IOI. 
Págs.

CAP. IV ، Rasgos característicos del ultraismo ............... 107-1 16

Intentos de darle un contenido teórico, 107. - La imagen, 108. - La tipografía, r 10. - Relación del ultraísmo con las artes plásticas, ir 4 .

CAP. V : Poetas del movimiento

Algunas consideraciones previas, 117. - Vicente Hui. dobro, I18. - Gerardo Diego, 125. - Juan La. rrea, 132: - Guillermo de Torre, 140. — Jorge Luis Borges, 143. - Pedro Garfias, 147. - Adriano del Valle, 150. -- Eugenio Montes, 151. - José Rivas Panedas, 153. - Rafael Lasso de la Vega, 155. - Isaac del Vando Villar, 157. - Otros poetas ultraistas, 159.

CONCLUsión: Balance $y$ fin del ultraismo $\ldots \ldots \ldots \ldots \ldots$ $165-169$

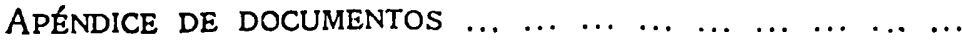
$171-215$

Proclama futurista a los españoles, de Tristán, 173.Lo más hermoso, de Cansinos-Asséns, 174. - La epopeya del ultra, de González Olmedilla, 175. - La .um. lirica y la revista "Cervantes", de Adriano del V. lle, 178. - De la fiesta del ultra, de Pedro Luis áe Gálvez, 181. - Mosaico leido por Juan González Olme. dilla en la fiesta del ultra, 183 - Instrucciones para leer a los poetas ultraistas, de (ansinos, 188. - Arte nuevo, de Antonio Espina, :72. - Otra vez Fierrera y Reissig, de Mauricio Bacarisse, 196. - Manifiesto Dadá, 198. - Proclama, 201. -- Al margen de la mo, dema lírica, de $\mathrm{J} \cdot \dot{ } \mathrm{L}$. Borges, 201 . - iVon serviam, de V. Huidobro, 204. - El creacionismo, de V. Huidobro, 206.

BIBLIOGRAFIA

Libros, 217. - Artículos, 223. - Periódicos y revistas citados, 233.

INDICES

Indice de nombres propios, 239. - Indice general, 245. 